\title{
Schmick'S Frontier: Native American And Moravian Community Building In Colonial Pennsylvania, 1753-1765
}

\author{
Megan Trent Mcgee \\ mmcgee8@mix.wvu.edu
}

Follow this and additional works at: https://researchrepository.wvu.edu/etd

Part of the History Commons

\section{Recommended Citation}

Mcgee, Megan Trent, "Schmick'S Frontier: Native American And Moravian Community Building In Colonial Pennsylvania, 1753-1765" (2018). Graduate Theses, Dissertations, and Problem Reports. 3725.

https://researchrepository.wvu.edu/etd/3725

This Dissertation is protected by copyright and/or related rights. It has been brought to you by the The Research Repository @ WVU with permission from the rights-holder(s). You are free to use this Dissertation in any way that is permitted by the copyright and related rights legislation that applies to your use. For other uses you must obtain permission from the rights-holder(s) directly, unless additional rights are indicated by a Creative Commons license in the record and/ or on the work itself. This Dissertation has been accepted for inclusion in WVU Graduate Theses, Dissertations, and Problem Reports collection by an authorized administrator of The Research Repository @ WVU.

For more information, please contact researchrepository@mail.wvu.edu. 


\title{
SCHMICK'S FRONTIER: NATIVE AMERICAN AND MORAVIAN COMMUNITY
} BUILDING IN COLONIAL PENNSYLVANIA, 1753-1765

\author{
Megan Trent McGee \\ Dissertation submitted to Eberly College \\ at West Virginia University \\ in partial fulfillment of the requirements \\ for the degree of \\ Doctor of Philosophy \\ in \\ History \\ Matthew Vester, Ph. D, Committee Chairperson
Tyler Boulware, Ph.D.
Tamba M'bayo, Ph. D.
Briane Turley, Ph.D.
Kristofer Ray, Ph.D.
Department of History
}

Morgantown, West Virginia

2018

Keywords: Moravians, Native Americans, Colonial Pennsylvania, Seven Years' War, Community Building

Copyright 2018 Megan Trent McGee 


\title{
Abstract \\ SCHMICK'S FRONTIER: NATIVE AMERICAN AND MORAVIAN COMMUNITY BUILDING IN COLONIAL \\ PENNSYLVANIA, 1753-1765
}

\author{
Megan Trent McGee
}

This dissertation explores community building during times of violence. I argue that the intense violence in Colonial Pennsylvania during the 1750s and 1760s did not prevent the Moravians from building multi-ethnic communities, even as other groups (French, British, and Iroquois) pursuing their own political gains sought to tear such communities apart. The project focuses on community building and cohesion during a time of violence. Both the Moravians and the Native Americans were marginalized outsiders in mid-eighteenth-century Pennsylvania. The Moravians were outsiders because they were Europeans who failed to integrate culturally with their European neighbors. The Delaware, Mohicans, and smaller Native American groups in Pennsylvania were outsiders because they were losing ground in the frontier and settlers were surrounding them. The violence of the North American conflict of the Seven Years' War (1754-1763) placed these marginalized groups in a position where they were stronger together than they were apart. An analysis of the Moravian community diaries showed that the community interacted and connected over three shared principles: culture, experiences, and goals. 


\section{Acknowledgements}

This project was helped by some people I sincerely need to thank. First, I would like to thank WVU's History department and my committee, Matt Vester, Tyler Boulware, Tamba M'bayo, Briane Turley, and Kris Ray. I am pleased that we chose each other to work with. I would like to particularly thank Matt Vester. Dr. Vester has been a boon to my research and my thinking over the years. His curiosity is contagious, and even if we did not agree completely, when I left his office, I felt rejuvenated and ready to work. Thank you. I would also like to thank the Center for Women's and Gender Studies. While gender does not play a substantial role in this research, WGST gave me an assistantship and the opportunity to teach for them-an experience that changed the way I teach and opened my eyes to others' experiences, privilege, and oppression. These are lessons that I used to shape my thinking in this project.

I would like to thank the friends I've made along the way. To my Ph.D. history girlsCassie Auble, Chris Grant, Lindsey McNellis, and Jenn Miller: you ladies rock. You've helped me calm down and cry when I needed to, supported me when I've asked for it, and kicked me into gear when I slacked. I love you all. The fact that we can be regular friends who talk about everything under the sun — and not just history — makes me happy that we found each other. To my WGST gang_Lacey Bonar, Matthew Carter, Kalo Mouki Sokoto, Briea St. Clair, and Dr. Kasi Jackson-I am so proud to have worked with you. Most of us come from different disciplines, but we all found friendship and laughter while fighting the patriarchy. You all inspire me to be a better person. Rock on! I would also like to thank Brandon Roos and Joe Snyder-my coffee buddies who would meet me where I was. If it was a hard day we would commiserate-if it was a happy day we would laugh about hilarious events. You guys helped keep me sane and I appreciate every cup. To Christina Davis, my best friend who has graciously let me spend my 
'free' time working on this project, I look forward to the days where we can go for walks, hang out, and laugh ourselves silly without deadlines limiting our time.

Lastly, I would like to thank my family. To my parents for always supporting me even when I made ridiculous decisions. You always had more faith in me than I had in myself. To my brother, Matt, for continuing to introduce me to awesome things that now I can finally experience. (Yay for anime and video games!!) To my sister-in-law (and fellow Ph.D. history girl) Lindsey: you are awesome, and I can only hope that one day I have your organization and focus_-but I won't because I'm me. To my in-laws, Gene and Nancy, who support me even when they can't seem to believe that I'm still in school: I'm getting this done so that I don't have to give back the earrings and necklace. Bribery works. To my sons, Deegan and Connor, I love you two more than you can imagine and I'm sorry that so much of our time has been spent with my face down in a book, iPad, or computer. But, I hope that you both look at my example and work hard for what you want. You will be amazing. And, finally, to my husband, Scott. You are the most amazing person I could ever hope to know and love. I am grateful that every day you continue to choose me. 


\section{TABLE OF CONTENTS}

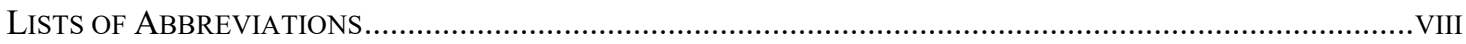

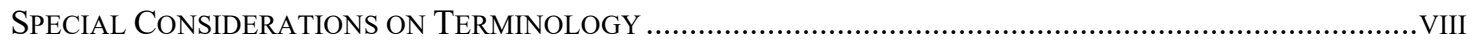

INTRODUCTION ................................................................................................................................................. 1

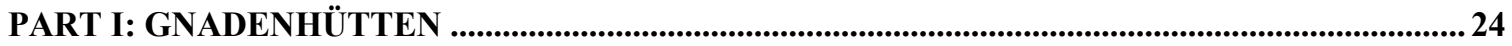

PENNSYLVANIA POLITICS..................................................................................................................... 25

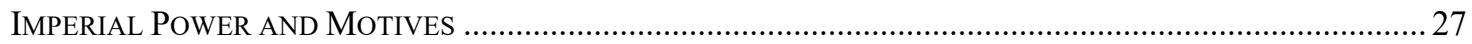

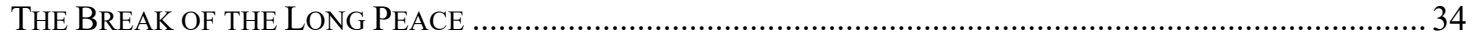

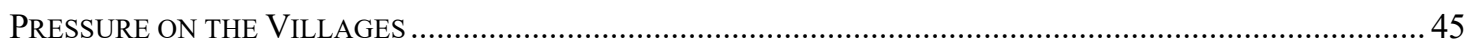

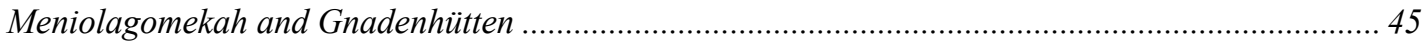

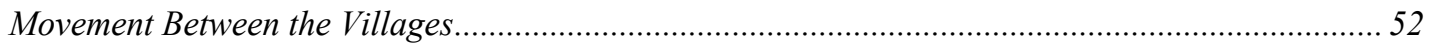

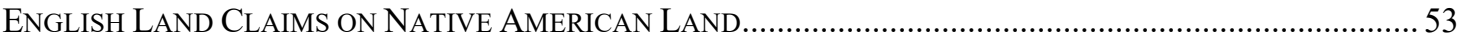

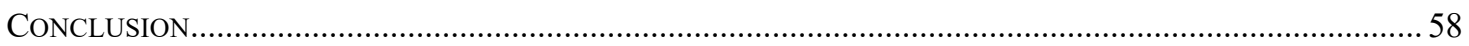

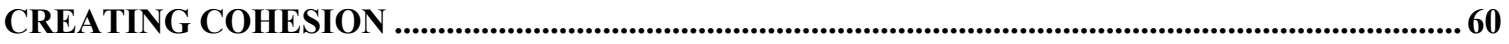

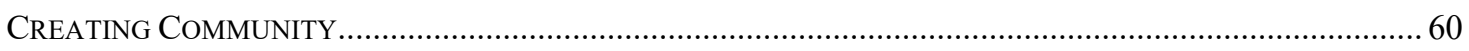

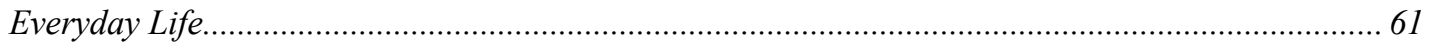

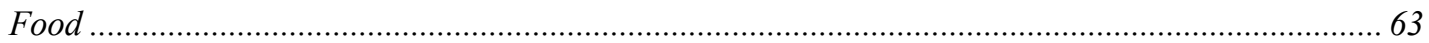

Life

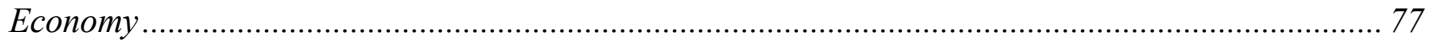

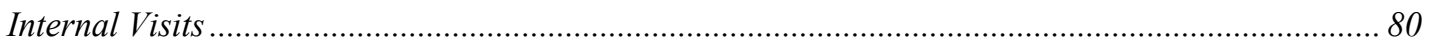

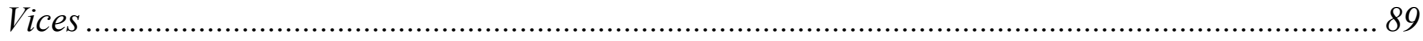

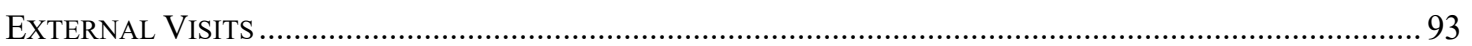

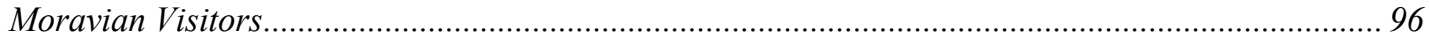

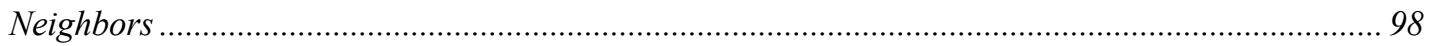

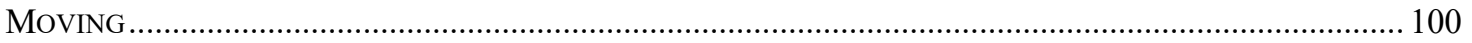

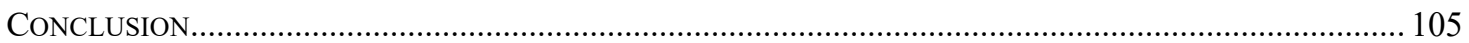




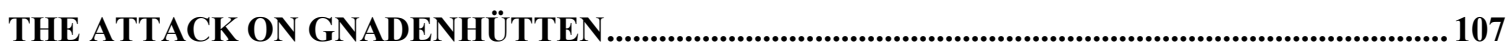

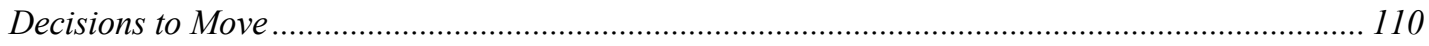

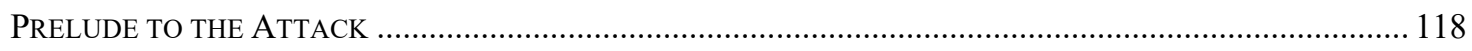

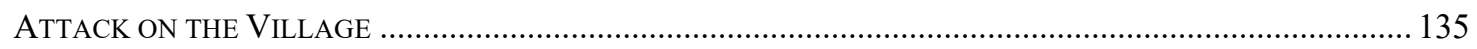

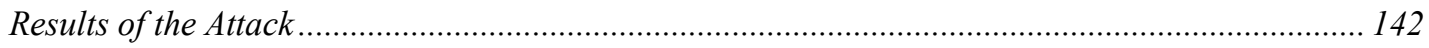

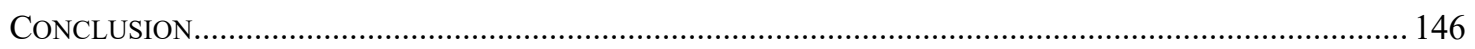

PART II: PHILADELPHIA ...................................................................................................................... 149

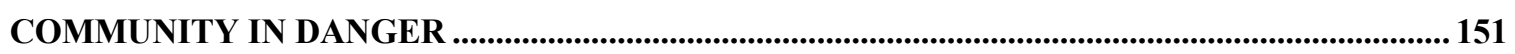

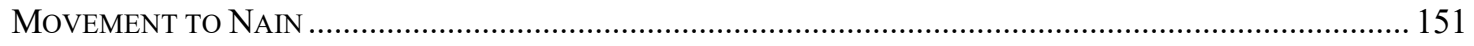

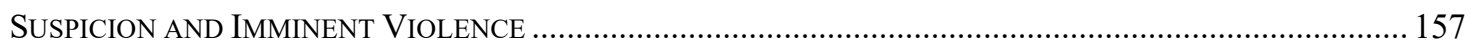

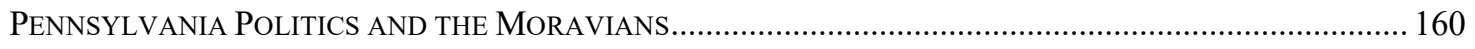

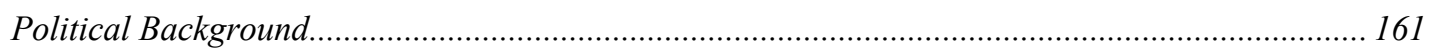

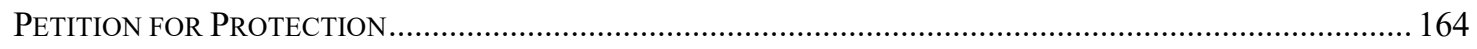

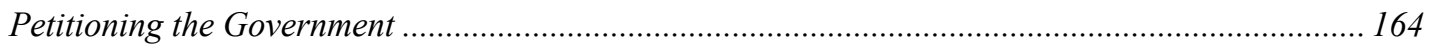

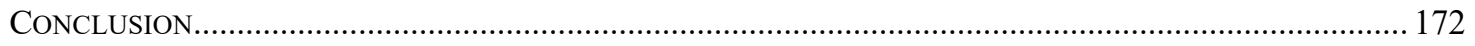

IMPRISONED COMMUNITY ...................................................................................................................... 174

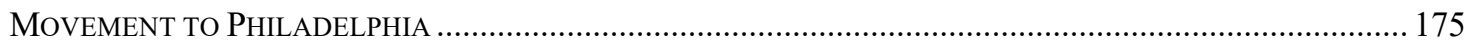

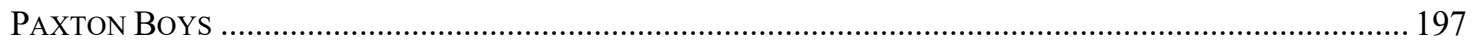

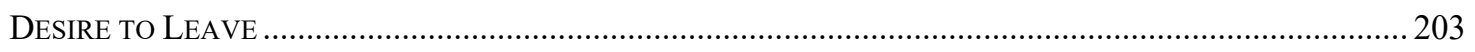

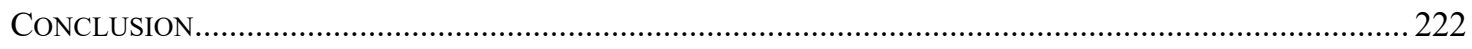

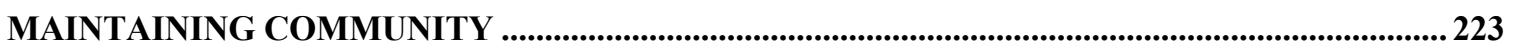

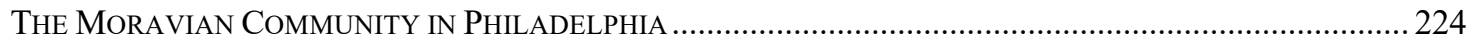

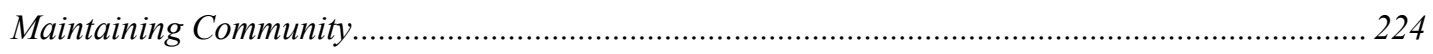

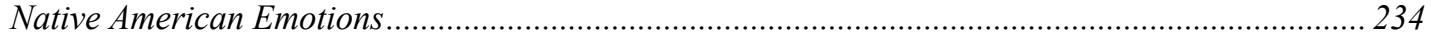

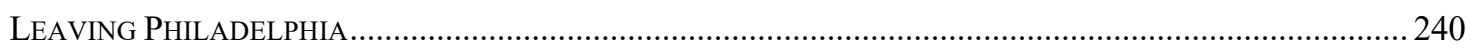

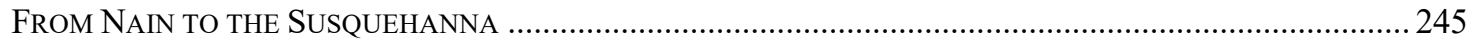

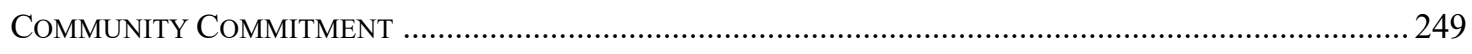




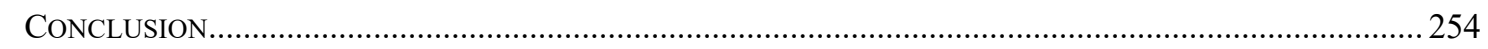

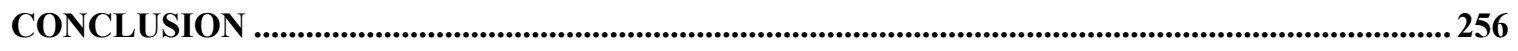

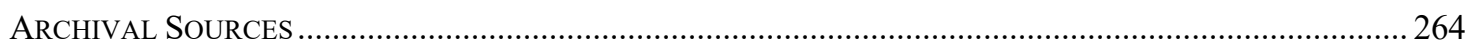

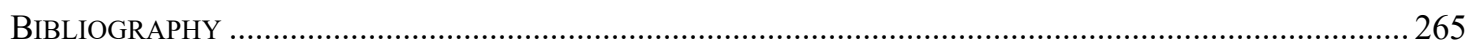

\section{TABLE OF FIGURES}

Figure 1: Political Players in Pennsylvania 1750s. Map by Megan McGee................................................ 28

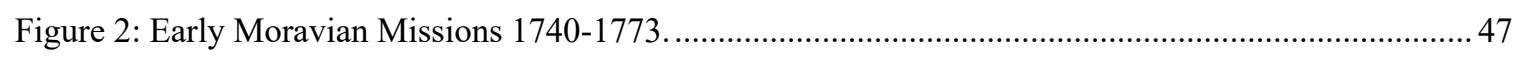

Figure 3: Early Village of Gnadenhütten.......................................................................................... 101

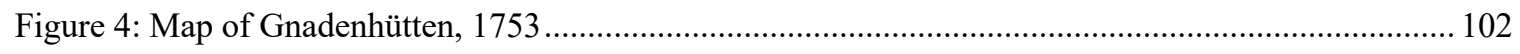

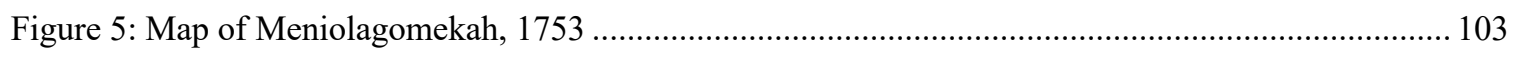

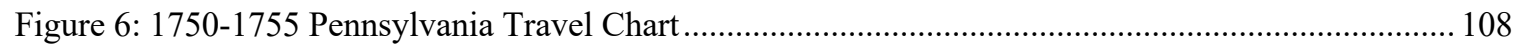




\title{
Lists of Abbreviations
}

\author{
MAB, Moravian Archives Bethlehem
}

MPCP, Minutes of the Provincial Council of Pennsylvania

\section{Special Considerations on Terminology}

One must keep in mind modern emotions and historical baggage when discussing and writing about oppressed cultures. I have considered arguments on terminology based on the opinions of Native American/American Indian activists. Currently there is little consensus on a preferred term. There are several governmental and activist groups that call themselves Indigenous, First Nation, Native American, American Indian, and Indian. An interesting argument against the use of Native American is that the term 'native' is indicative to anyone born within America (as evidenced by the rise of 'nativism', essentially white European American culture) while removing the connection to the atrocities carried out by Americans on the Indians. In this way, the term Native American whitewashes the violence of the European Americans because Native Americans are the contemporary people, while Indians were the ones who were demonized and attacked. ${ }^{1}$ Because of that connection to historical violence against a people, some activists are embracing the term American Indian, since they are the descendants of the first Americans and they are radically embracing the history of the Indians. Others are less concerned with the semantics and more interested in connecting to their tribal heritage, naming themselves by their tribe and clan, traditional means of distinction. In this project, all the above

${ }^{1}$ Engels, "Equipped for Murder: The Paxton Boys and 'the Spirit of Killing All Indians' in Pennsylvania, 1763-1764", Rhetoric \& Public Affairs, 8, no.3 (2005). This article examines the rhetoric of the word Indian. 
terms may be used interchangeably, to reduce repetition. Activists also have been accepting of the word tribe when it comes to their general political unit under the nation. In all accounts I will try to use the name of the nation, tribe, or clan in question, if noted in the diary or letter. Subsequently, this project will use the following definitions and distinctions.

- Indians - meaning American Indians generally or with unknown loyalty.

- Friendly Indians - Unbaptized American Indians who the Moravians or their congregants know personally or tribally as friends and family.

- Christian Indians - Baptized American Indians - regardless of denomination: primarily Moravian.

- Brown and white - in their diaries the Moravians generally made the distinction between the Indian and European brethren by naming them brown and white. For instance, there were often separate services for the brown brethren and the white brethren, where the Indian elders would lead the brown congregants in a language they understood, usually Mohican or Delaware, and the white brethren would have their service in German. I will only use these terms when translating and quoting the diaries. There is interesting research done of the racialization of Indians and the use of red to describe their color, yet I have not read any diary entry where the Moravians refer to their Indian congregants or visitors as red, instead always opting for brown.

- Brethren, brothers, sisters - the Moravians called each other Brother and Sister. Together they are Brethren, or in German, siblings. So, when the gendered choirs are meeting separately the diary will make the distinction that the brothers or sisters are meeting. But, when the diary records that the siblings are meeting it is gender inclusive, that the brothers and the sisters are meeting together. 
- Moravian, or Brethren — members of the United Brethren pietist movement. Also known as Moravians due to the country of religious origin. I will usually be referring to them as Moravian.

- German — generally meaning German speaking. Germany was not a unified state during this period. Instead, German-speakers spread German culture and language throughout several states, cities, duchies, and empires in Europe. In the American colonies, it was the English colonists who determined that German was an identity, based on a shared language and culture. ${ }^{2}$

- Pennsylvania - meaning the modern boundaries of the state. During the colonial and early American periods, the boundaries of the colony and, later, the state, were contested. First by the indigenous population, then by France, again by the American Indians, and then by Virginia, who claimed the southwestern part of the Ohio River Valley that connects to the West Virginian (Virginia prior to 1863) panhandle, and even by Connecticut in the Upper Susquehanna River Valley. These distinctions and boundaries are fascinating to explore, but for ease of reference I will be using the modern boundaries of the Commonwealth of Pennsylvania.

${ }^{2}$ Philip Otterness, Becoming German: The 1709 Palatine Migration to New York (Cornell University Press, 


\section{Introduction}

This dissertation began as a seminar paper. I was looking for a project that would focus on the interactions of Native Americans and German-speaking immigrants. Colonial American history tends to focus on English immigrants, but there were hundreds of thousands of Germanspeaking immigrants in the colonies under-represented in scholarship. After initial research I

found that the Moravians (a German-speaking religious group) were active in missionary work to Native Americans in colonial Pennsylvania. Moravians left detailed records of their missions: letters between the mission village and Bethlehem, Pennsylvania (the center of the North American Moravian Church), community diaries of the mission villages, memorandums and catalogues of the baptized Indians, and maps of the villages and surrounding land. Historians often overlooked these sources or only used them supplementarily due to the difficulty of eighteenth-century German script. My research takes these often-ignored sources and places them at the center of my arguments and analyses.

My dissertation argues that the intense violence in Colonial Pennsylvania during the 1750s and 1760s did not prevent the Moravians from building multi-ethnic communities, even as other groups (French, British, and Iroquois) pursuing their own political gains sought to tear such communities apart. The project focuses on community building and cohesion during a time of violence. Both the Moravians and the Native Americans were marginalized outsiders in mideighteenth-century Pennsylvania. The Moravians were outsiders because they were Europeans who failed to integrate culturally with the English, and the Delaware, Mohicans, and smaller Native American groups in Pennsylvania were outsiders because they were losing ground in the frontier and settlers were surrounding them. The violence of the North American conflict of the 
Seven Years' War (1754-1763) placed these marginalized groups in a position where they were stronger together than they were apart. ${ }^{1}$

A unique factor of the Moravians was that while they were a religious group whose goal was Indian conversion, they were not agents of empire. Other missionaries, especially Catholic missionaries, who came to the Americas did so as agents of empire. To solidify the imperial goals of France and Spain, the Catholic countries, Jesuit and Franciscan monks converted indigenous peoples and forced them to adhere to European cultural ideals. Moravians, conversely, were a highly evangelical Protestant group who came to North America to spread their faith, not their culture or political power.

The Moravians, independent from imperial force, did not want to be politically involved in the hostility on the Pennsylvania frontier. They were pacifistic and tried to focus on spiritual connections rather than political power and maneuvering. However, the divisiveness of the period led to the inevitable involvement of the Moravians and their Native American converts in the politics and tensions of the period. Large political players (England, France, and the Iroquois Confederacy) forced the Moravians (both Europeans and Native Americans) into action. When the Moravians tried to remain outside of the turmoil, their inaction led to the destruction of the village of Gnadenhütten, and the eventual internment of the Native American congregants.

\footnotetext{
${ }^{1}$ Many in America refer to this as the French and Indian War. However, historians often prefer to place this conflict within the larger imperial and world context of the Seven Years' War. Additionally, naming the North American conflict the French and Indian War overlooks the British involvement and even implies that there were no Native Americans allied with the British. Many students do not recognize that the French and Indian War was not a war of the French against the Indians (who were not a monolithic group). When I refer to this war, I will refer to it as the Seven Years' War.
} 
Scholars have not done an in-depth analysis on the village of Gnadenhütten. There is little historiography on the topic in which to place myself. Jane Merritt, in At the Crossroads, discusses the Moravians and their relationships with Native Americans in Gnadenhütten around the increased racial tensions of the time. Her focus lay not in how the Moravians created a cohesive community, but rather how the community "adjusted to the growing presence of white settlers before 1755."2 Yet, the community building process and its eventual destruction did not play a significant role in her analysis. In fact, she recounted the destruction of the community in three pages.

This project is a microhistory of the Moravian community of Gnadenhütten. This community was not rooted in a specific place and did not rely on a particular person to lead it, but it was one of synthesized faith. Interactions between Moravian missionaries and Native Americans built a community that was able to withstand the political pressures of the mideighteenth century. The combined goals of Moravians and Native Americans created a sense of belonging that allowed the community to continue during times of violence. It is impossible to determine the level of understanding between the two groups, given that the traditional Native American culture did not have specific religious beliefs or dogma. Instead, it is likely that the Moravians' open acceptance of faith through words and the Native American willingness to listen and speak those words led to a relationship where both groups benefitted.

This project defines community as a social construct in which Moravians and Native Americans use both practical and symbolic approaches as described by anthropologists and

2 Jane Merritt, At the Crossroads: Indians and Empires on a Mid-Atlantic Frontier, 1700-1763, (The university of North Carolina Press, 2003), 6-7. Chapters 3 and 4 focus on the Moravians and their interactions with Native Americans. 
sociologists to unite an otherwise disparate set of people. An analysis of the diaries showed that the community interacted and connected over three shared principles: culture, experiences, and goals. These three principles coincided with three traditional aspects of social cohesion that sociologists and anthropologists, W. Lloyd Warner, Ronald Frankenberg, and David Minar and Scott Greer, examined.

Warner, in 1941, defined community as "a socially functioning whole: a body of people bound to a common social structure which functions as a specific organism, and which is distinguishable from other such organisms."3 Based on this definition, the community of this project, Gnadenhütten, was distinguished from the English and other Native American groups by either race, religion, or culture. This broad definition, however, did not consider how or why those communities became cohesive. Frankenberg, in 1966, examined the role of community creation and noted that, "it is common interests in achievable things (economic, religious, or whatever) that give members of a community a common interest in one another."4 This theory explains the cohesion of the Moravian community in Gnadenhütten as well as the exclusion of those neighbors who were outside of the religious and economic goals of the village. ${ }^{5}$ In 1969 , Minar and Greer added to Warner and Frankenberg by specifying that "physical concentration (living and working) in one geographical territory is key." ${ }^{\prime 6}$ In our case, the village of Gnadenhütten, nestled in eastern Pennsylvania's Blue Mountains, had cohesion due to common experiences based on location. However, other nearby villages did not join a larger community

${ }^{3}$ Nigel Rapport, Social and Cultural Anthropology: The Key Concepts, (Routledge, 2014), 79.

${ }^{4}$ Rapport, 79.

5 The village was more likely to exclude other European groups than other Indians. The Moravians' primary goal was conversion, so they wanted the village to remain open to unbaptized, friendly Indians.

${ }^{6}$ Rapport, 79. 
with the Moravians, due to the Moravians' separate culture and unique Christian beliefs. I believe that community is made up of each of these parts, combined with a symbolic community consciousness that grows from these shared experiences, culture, and goals.

These theories coincided with the interactions I witnessed in the communal diaries. The community was initially one of place, Gnadenhütten, which gave the members shared experiences. Shared goals: the religious experience, a shared economy, and daily life, bolstered the village. These aspects helped create a community consciousness where the members of the village saw themselves as a cohesive group. They created a shared culture that was a direct response to the shared goals and experiences of the village. This shared culture meant that regardless of where the village was, the members of the community recognized the cohesion within it. This culture was not wholly German nor completely Native American. It was a combined culture where the groups united for mutual benefit. ${ }^{7}$ The benefit to the Moravians was the conversion of the Indians, the primary objective of the missionaries. The Indians benefitted by having European patronage during a time when European settlers were overrunning the land. Having support from Europeans protected the Indians from other European immigrants.

To create multi-cultural cohesion, both groups had to compromise. The Moravians had to overlook that their Native American converts may not be entirely earnest in their conversion given the fact that their cosmology did not have the language to understand fundamental ideas of

\footnotetext{
${ }^{7}$ Chela Sandolval's Theory of Differential Consciousness examines coalition building by marginalized groups. She focuses on third world feminists, but we can see her idea in action here. The marginalized people (in this case both the Moravians and Native Americans) had to "learn to highlight (or obscure) different aspects of themselves in order to work effectively within political organizations." While I do not view the village of Gnadenhütten as a political organization I recognize that both the Moravians and the Indians had a give and take relationship with one another where they may have made the conscious decision to ignore certain aspects in order to create and maintain strong community cohesion. Paula M. L. Moya, Learning from Experience: Minority Identities, Multicultural Struggles. (Berkeley: University of California Press, 2002), 79.
} 
Western Christianity. However, the Moravians only demanded the Indians' professions of faith, not specific adherence to dogma. The Indians adopted some of the Moravian culture (learning German, praying throughout the day, reciting professions of faith) while also maintaining essential aspects of their own culture, like hunting, gathering, and the prominent role of women in society. The influential role of women in Moravian culture, as leaders and confidants, was appealing to Native American women — who would not have to give up social power with conversion. Indian women, who held substantial amounts of social and cultural capital in traditional villages, remained active and socially significant in the combined ethnicity village.

This community's defining factor, despite its ambiguity, was religion. Other aspects, like education and economy, also played a role but what set Gnadenhütten apart from other eastern Pennsylvania towns and villages was the religion of the multi-ethnic group. While other connections, like kinship, contributed to the demographics of the village, these people chose to live in Gnadenhütten together based on shared faith and mutual benefit. Religion brought the group together, and religion also kept them apart from other groups-whether Native American or European. The Moravians' feminization of the Holy Spirit disturbed other Protestant groups in Pennsylvania, while other Indian groups were experiencing a Great Awakening based on traditional and reactionary beliefs. Due to the pietistic nature of the Moravians, they were adapted well to both missionizing and creating multi-ethnic religious communities. They demanded professions of faith from their converts but did not force them to give up many Native American traditions.

The Moravians remained outsiders within the growing identity consciousness of European immigrants in large part due to their beliefs. Although specific beliefs of the Moravians will not play a significant role in this project, it is essential to recognize how they were different from other missionary groups that preached in the mid-eighteenth century. In 
many ways it was the lack of enforced dogma that allowed the Moravians to create cohesive missions all over the world. Moravians are a pietist group that trace their beginnings to Jan Hus in the fifteenth century and gained popularity in Central Europe in the mid-eighteenth century. They focused on individual relationships with God, Jesus, and the Holy Spirit, rather than belief in specific dogma. Count Nikolaus Ludwig von Zinzendorf reinvigorated the Moravian Church in the early eighteenth century. He opened his family lands in Herrnhut, Saxony in 1722 to Moravians who searched for religious freedom. After converting to Moravianism from pietist Lutheranism, Zinzendorf preached throughout Europe, promoting immersion into communities and cultures. He orchestrated the movement of Moravians to colonial America, creating missionary towns in Georgia and South Carolina. ${ }^{8}$ Due to violence among colonists and American Indians, many Moravians moved north and settled in Bethlehem, Pennsylvania in 1742. In Bethlehem, the Moravian transplants began large-scale missions to local American Indians.

Moravian missionaries were unique as they immersed themselves in Indian society and created missionary towns where Moravian leaders could interact with and convert Indians. Many historians consider Moravians the most successful of the eighteenth-century Indian missionary groups, with David Zeisberger and John Heckewelder as the most famous of the missionaries. ${ }^{9}$

${ }^{8}$ John Wesley, Letters of John Wesley, ed. George Eayres, (Hodder and Stoughton, 1915). John Wesley, one of the founders of Methodism, had a brief period with the Moravians and respected their faith. On a trip to the new colony of Georgia in 1735, Wesley interacted with several Moravians who were also on their way to the colony. His letters indicate that he felt inspired by the Moravians' faith, but did not feel comfortable with their lack of scriptural adherence.

${ }^{9}$ Paul A. W. Wallace, "They Knew the Indian: The Men Who Wrote the Moravian Records," Proceedings of the American Philosophical Society 95, no. 3 (June 12, 1951): 290-95; Daniel Vickers, A Companion to Colonial America (John Wiley \& Sons, 2008); Laura M Stevens, The Poor Indians: British Missionaries, Native Americans, and Colonial Sensibility (University of Pennsylvania Press, 2010). 
They were also unique because they assimilated economically into the English colonial culture (the English being their nearest European neighbors), while remaining socially and culturally separate. The Moravians were both pacifists and ethnic outsiders who maintained their language, religion, and culture; thus, they remained outsiders socially and politically. Other Germanspeaking immigrants even dismissed Moravians, regardless of similar language and culture. Aaron Fogelman argues that other German groups, especially Reformed Church and Lutherans, excluded the Moravians due to unorthodox beliefs concerning feminine aspects of the Holy Trinity. ${ }^{10}$ The English distrusted Moravian Brethren due to their intimate connections to American Indians, and many unconverted American Indians distrusted the Moravians due to their European heritage. ${ }^{11}$

European and Native American interactions were often imperialistic. Native American historians, often due to lack of Native American sources, usually focus on the relationships between Empires and Native Americans. Instead of viewing the relationships in binary, as an oppressed and oppressor, invader and invaded, in 1991, Richard White wrote The Middle Ground, which focused on cooperation between powers (in White's case, French and Algonquian-speaking Native Americans) rather than conquest. ${ }^{12}$ These two groups were in constant negotiation to remain in balance. Yet, this middle ground did not exist everywhere that Natives and Europeans interacted. The balance of interaction often depended on place, historical

\footnotetext{
${ }^{10}$ Aaron Spencer Fogleman, Jesus Is Female: Moravians and the Challenge of Radical Religion in Early America (University of Pennsylvania Press, 2007).

${ }^{11}$ Otterness, Becoming German.

${ }^{12}$ Richard White, The Middle Ground, Indians, Empires, and Republics in the Great Lakes Region, 16501815 (Cambridge University Press, 2010).
} 
interactions, and demographics. Kathleen DuVal, in 2006, explored the Arkansas River Valley and argued that the Natives were the ones who held the power until demographics shifted the balance. ${ }^{13}$ In The Native Ground, she took White's middle ground idea and argued that most interactions were made on native ground until the balance of power shifted from Native American. For many of the interactions in the Arkansas River Valley it was the Europeans who had to modify their behaviors to be acceptable to the Indians. Yet, population increase and changing demographics led to native ground giving way to a middle ground before finally becoming a European or American ground.

The changing demographics that disrupted the balance of power also played a part in creating an American (white European) identity. Tom Hatley, in 1993, argued that in South Carolina the negotiations of the middle ground and the changing power balance led to identity formation in the colony. ${ }^{14}$ The struggle between the Cherokee and the colonists led to them recognizing one another as different and people like them as the same. Their interactions helped solidify their identities - as either Cherokee or Carolinian.

Such shifts in power are explored in Jane Merritt's, At the Crossroads, and Philip Silver's, Our Savage Neighbor, who both look at identity formation due to shifts on the Pennsylvania frontier. Merritt, 2003, explored the middle ground framework and applied it to Pennsylvania and identity formation. She argued that, "the difference among Pennsylvania immigrants — whether political, economic, social, religious, ethnic, or racial—once negotiable

${ }^{13}$ Kathleen DuVal, The Native Ground: Indians and Colonists in the Heart of the Continent (University of Pennsylvania Press, 2011).

${ }^{14}$ Tom Hatley, The Dividing Paths: Cherokees and South Carolinians Through the Era of Revolution (Oxford University Press, 1993). 
and often tolerated at a local level, became increasingly characterized by race ('Indianness') by the 1760s." 15 Merritt, by looking at Pennsylvania, showed that the violence racialized into a binary of us versus them. While she focused on the increasing Indianness, Silver, in 2008, flipped the script. Instead of focusing on increased Indianness, he examined how, due to the role of racial jargon in newspapers, European groups (whether Scots-Irish, German, or English), began to identify themselves as white, diametrically opposed to the Indian. ${ }^{16}$

Within the concept of native ground, middle ground, and European ground, I argue that the English were trying to use the dominating force of European ground against the Moravian Indians, while the Moravians were still working within the framework of middle ground: negotiating and creating a synthesized village of German Moravians and Native Americans based on faith. I add to White by exploring how the Moravians were fighting against imperial pressures of domination to try and create a middle ground in a diminishing frontier. Additionally, these Moravians were facing socially constructed identities formed in the violence of the years surrounding the Seven Years' War. While Silver moved focus from the creation of Indianness, Merritt's focus, to the creation of a white identity, my work also explores the exclusion of 'white' groups within that European-centric identity. Settlers and Native Americans targeted Moravians, and their Indian congregants, as outsiders. Also, Merritt argued that the voluntary move from the village of Gnadenhütten due to political pressure in 1754 marked a decline in the

15 Jane T. Merritt, At the Crossroads: Indians and Empires on a Mid-Atlantic Frontier, 1700-1763 (The University of North Carolina Press, 2011). Co., 2008), xx.

${ }^{16}$ Philip Silver, Our Savage Neighbors: How Indian War Transformed Early America (W.W. Norton \& 
mission. ${ }^{17}$ While a substantial number of people left the village, I argue that they had multiple reasons to leave, but many people also remained, which continued to strengthen the community.

Historically, Pennsylvania had a fairly amiable relationship with the indigenous population until closer to the mid-eighteenth century. James Merrell explained the breakdown between Native Americans and European immigrants' relations in Pennsylvania in four distinct phases: $1682-1700,1700-1720,1720-1737$, and 1737 to the mid-eighteenth century. ${ }^{18}$ From 1682 to 1700 , the American Indians and colonists in Pennsylvania lived in relative peace and prosperity. These groups interacted with each other and coexisted in tentative friendship. There was no outright hostility between the groups, unlike in other, earlier, settled colonies. This lack of hostility could be due to the respect that William Penn gave American Indians, creating friendships, treaties, and paying for Delaware land near the Susquehanna River, rather than claiming the land regardless of the inhabitation of an indigenous population.

After 1700, English colonists continued to push against the land of the American Indians. The European Americans pushed against the Delaware and Shawnee. Other American Indian tribes, displaced by wars in the south, moved into Pennsylvania, creating even more friction over resources and identity. Eighteenth-century Pennsylvania was primarily a colony of immigrants and movement. Not only were European Americans immigrants, but there were also numerous American Indian migrants, who fled wars and were searching for peace and stability.

By the late 1720s, governmental leaders in Philadelphia decided to begin negotiations with the Iroquois Confederacy rather than focus their politics on smaller, less politically

\footnotetext{
${ }^{17}$ Merritt, 159.

18 James H. Merrell, Into the American Woods: Negotiators on the Pennsylvania Frontier (W. W. Norton \& Company, 2000).
} 
powerful local tribes like the Delaware, Shawnee, Nanticoke, Susquehannock, and Mohican. The English viewed the size of the Iroquois Confederacy as proof of their power and legitimacy. The English were an imperial power and, as such, dealt with large, powerful allies. Additionally, with the death of William Penn, and the ascendancy of his sons, much of the goodwill that soothed the interactions of American Indians and European Americans disappeared. This growing animosity was especially evident with the Walking Purchase of 1737, when the Penns swindled the Delaware out of thousands of acres of land. When the Delaware petitioned the Iroquois for aid against the illegal acquisition, the Iroquois claimed neutrality and refused to help the Delaware.

While the eastern side of the colony was rife with tension over broken treaties, angry neighbors, and the never-ending stream of European immigrants, the Ohio River Valley in the west was becoming problematic. By the 1750s the French began constructing forts along the Ohio River. They aimed to create a large-scale North American empire based on the river routes. These forts would connect their lands in Canada and Louisiana, putting a vast swath of land and trade routes under French rule.

Imperial powers were squeezing the Eastern Woodland Indians, primarily Delaware, Mohicans, and Shawnee on all sides. The French empire was beginning to push in from the west, the British empire was expanding from the south and the east, and tribes within the Iroquois Confederacy were exerting pressure from the north. Initially, each of these large political groups was trying to consolidate power and was attempting to unite with smaller tribes to bolster their claims and numbers. The Moravians were not acting with any political or territorial goal, unlike the political powers who were trying to pull smaller Indian polities away from their homes. Instead, the Moravians tried to create multi-ethnic communities based on shared faith regardless of culture or politics, in a place that had traditionally been open to compromise. 
Pennsylvania was a perfect colony for the Moravians. As a Quaker, William Penn actively recruited Germans to populate his new province. He recruited due to the pacifistic nature that many German pietist religions, including Moravians, adhered to, which was similar to the pacifistic Quaker faith of Penn. By the time that the Moravians moved north to Pennsylvania, there were already several German groups living within the colony. Many of these groups found a land that was reminiscent of the forests of Germany. Additionally, the cultural demographics were perfect for the missionizing Moravians. They were not interested in converting Europeans who were already Christians. Instead, they focused on American Indians and slaves who had little practical experience with Christianity.

By the mid-eighteenth century, the Moravians had a handful of mission towns in eastern Pennsylvania. They placed their towns near Indian towns to more easily access the Indians. Moravians lived in the frontier of Pennsylvania, beyond the influence of Philadelphia. They lived alongside the Shawnee, Mohicans, Delawares, and other less populous groups. The relationship of Moravians and Indians was one of cooperation and mutual benefit. The Indians depended on the Moravians for protection from European immigrants and unfriendly Indians. The Moravians, meanwhile, depended on their Indian congregants for information about the frontier, work done in the village, meat from hunting, and most importantly to the Moravians, for their conversions. The primary goal for the Moravians was to convert American Indian people - which made them dependent on the natives. Without the American Indians, Moravians would have no one to preach to and convert, making their primary goal useless.

The Native Americans the Moravians targeted for conversion were under the political purview of the Iroquois confederacy while remaining able to make their own political and tribal choices. Before the arrival of Europeans, the Iroquois Confederacy was the political powerhouse in the eastern mid-Atlantic states, known as the Eastern Woodlands. While their traditional tribal 
lands were to the north of modern Pennsylvania, their political influence extended into the Susquehanna and Ohio River valleys. ${ }^{19}$ The native tribes that were indigenous to the eastern part of Pennsylvania were the Delaware (Leni Lenape), Shawnee, and Mohican. While these groups were not part of the Iroquois Confederacy, they maintained a complicated relationship with the Iroquois, while technically being under their political purview. In this case, they looked at the Iroquois as uncles, and each other as brothers. In the matrilineal culture of eastern woodland Indians the maternal uncle was the most influential man in a young man's life. By designating the Iroquois as 'uncle,' the smaller tribes were indicating that the Iroquois were the most powerful figure in the life of the tribe. By recognizing each other as 'brothers' the Delaware, Shawnee, and Mohicans were placing them all at the same political level.

The Iroquois looked at the Delaware, the largest of the local groups, as women. This diplomatic designation was not in any misogynistic sense of the term, but as people who are welcome at the longhouse and protected, who will not fight but give counsel. Women in many American Indian cultures, including the Delaware, Shawnee, Mohican, and Iroquois were influential leaders. They were not sachems or chiefs, but gave their opinions when voting on new chiefs, determining kinship (many adopted kin), and deciding torture. These smaller native groups (Delaware, Shawnee, and Mohican) had their own leaders, their traditions, and variations of language. Politically, they were not united. They fought over land and resources that became scarcer as European settlers began to arrive and gradually overtake native neighbors.

\footnotetext{
${ }^{19}$ The Iroquois Confederacy consisted of five nations until 1722 when the Tuscaroras, who fled north form Carolina, joined them, thus creating the Six Nations.
} 
The Moravians, however, did not compete and fight over land with the indigenous people in Pennsylvania. Instead, they wanted to compromise and live together in a community, together on the same land. Moravians were diligent in their efforts to reach their native flock. They lived among the Indians and created communities with Christian Indians, regardless of poverty or tribal makeup. Laura Stevens noted that the Moravians did not attempt to create personal names for themselves, they did not write and publish sermons, and they meant for their diaries to help other Moravian missionaries in their efforts to convert American Indians. ${ }^{20}$

Their diaries are the congregational diaries for the missions that the Moravians conducted. Usually, a single missionary wrote the diaries for the entire village. They recorded the daily life, Alltagsgeschichte, of the Moravians and their converts. These diaries recounted the daily struggles, the spiritual goals, and the success and failures of the community. The missionaries wrote them with an audience in mind, not a commercial audience, but rather other Moravian mission towns. Bethlehem sent copies of village and town diaries to other missions to create a more extensive worldwide community.

Many American historians fail to use the community diaries because they are difficult sources to use. Handwriting in a script that modern Germans no longer use makes them extremely challenging to read and analyze. There was no standardized spelling or grammar, which makes the handwritten script even harder to decipher. Instead of trying to translate difficult sources, historians make heavy use of the travel diaries of David Zeisberger and John Heckewelder, two missionaries translated into English at the turn of the twentieth century. Thus,

\footnotetext{
${ }^{20}$ Stevens, 27.
} 
my heavy use of these community diaries is new to the scholarship. Few American researchers read eighteenth-century German handwriting and those who do use them supplementally rather than as the prime focus of their analysis. The Bethlehem archives also include letters that missionaries and church leaders wrote, as well as catalogs of converted Indians, and maps of mission villages. The bulk of my research comes from these community diaries, but I also use colonial records, Moravian catalogs, Moravian letters, and the Minutes of the Provincial Council of Pennsylvania to further support my overall argument.

Since the diaries are wide-ranging in time and place, I decided to follow Johann Jacob Schmick, a little-known Moravian missionary, and explore where the church stationed him from 1753-1765. For those years I follow Schmick through the Pennsylvania frontier during some of the most turbulent time of the colony's past. Schmick is a tool, the lynchpin of my research. The focus is not on him as a person, but his movements through the community he served to explore how the political and racial tensions of Pennsylvania affected a single multi-ethnic community.

Schmick was born in Königsberg, Prussia in 1714, raised Lutheran and became an ordained Lutheran minister. In 1742, while ministering to children in Livonia, he met Moravians and decided to convert. In 1748, Schmick fully converted to Moravianism, taking his first communion with them; by 1751 , he immigrated to Pennsylvania to lead missions to American Indians, even becoming adopted by the Shawnee. Schmick was a renowned musician and preacher. Lawrence Hartzell wrote that Schmick played several instruments and had a powerful singing voice. ${ }^{21}$ The diaries noted this musical nature. In 1754, Schmick went to ease a sick boy

${ }^{21}$ Lawrence W Hartzell, Ohio Moravian Music (Moravian Music Foundation Press, 1988). 
(young Jacob Junior) by playing his violin and singing for him, and the boy felt much better after the visit. ${ }^{22}$ After the turmoil of the Seven Years War, he and Zeisberger led their American Indian converts to Philadelphia for protection from Scots-Irish immigrants who were attacking and killing Indians. Once the immediate threat ended, Schmick and Zeisberger went north with their converts and founded the village of Friedenshütten, in modern-day Bradford County, Pennsylvania in 1765.

This project focuses on the following research question: during a time of increasing racialized violence, how did the Moravians create and maintain a cohesive multi-ethnic community? DuVal and White argue a trajectory where the indigenous people were in positions of power over white settlers to places where there was cooperation between the two groups. The actors worked together cooperatively—which is what the early part of Pennsylvania colonial history shows. Europeans interacted well with their Native American neighbors. With the influx of the mostly Presbyterian Scots-Irish, along with the violence of imperial wars, especially the Seven Years' War, we see a breakdown of that cooperation into a relationship of dominance where the English were in a position of power and making demands of the smaller Native American groups in Pennsylvania. Merritt and Silver discuss the racialization and the hardening of lines between the white settlers and the Indians. This project adds to this scholarship by focusing on a small group to see how these changes are affecting them as a multi-ethnic community.

${ }^{22}$ MAB, MissInd 1.11.118.1, June 2, 1754. 
There is evidence of community-building in the demographic makeup of the villages that the Moravians and Indians created. Varying tribes and languages filled the villages, including tribes who historically fought against one another, like the Mohican and Delaware. These Moravian villages maintained extensive historical records - daily diaries of the movements and lives of the people within the community. Through these diaries, we can explore how the Moravians tried to build communities that other groups, Native, English, and French, were trying to tear apart.

According to the analysis of these diaries, the Moravians built community in three primary ways: through shared experiences, shared culture, and shared goals. The Moravians, like the French Jesuits, but unlike many English missionaries, lived among the Indians. Their shared experiences consisted of the realities of daily life: work, planting, harvest, hunts, food, starvation, marriages, births, sicknesses, and deaths. The diaries make it clear that Moravians and their Indian congregants experienced the obstacles and joys of life together.

The Moravians shared their daily experiences with their Indian neighbors; one of their main goals, however, was to share their culture. The Moravians were, perhaps, one of the least culturally imperialistic groups that interacted with American Indians, but their religious mission focused on turning Indians into Christians, thereby changing their culture. Moravians were not culturally imperialistic — while they fought for conversions, they accepted a spectrum of faith among their converts, where individual members were able to interact with Jesus and God in ways, and depths, that they wanted. This acceptance helped create the mutually beneficial community. Had the Moravians demanded full understanding and cultural assimilation, it is probable that their community would not have been as cohesive.

American Indian belief, like most aspects of Native American history, was not monolithic. Instead, it depended on nation, location, and ecology. Many of the eastern woodland 
Indians, including the Indian groups with which the Moravians had interactions within Pennsylvania, belonged to matrilineal cultures that traditionally had a cosmology which was unlike patriarchal European Christianity. Indian culture intertwined life and harvest, which explains why mother earth and the corn mother were essential to these agricultural communities. The biological fact that women are the ones who carry and bear children made the connection between women and the environment obvious. Transforming a matrilineal society with an undogmatic cosmology into one that believes in a male God was a daunting task, but one for which the Moravians were particularly well-suited. The Moravians cared more personal relationships with God and the holy than for any defined dogma. This personal connection to God and the holy translated well with the personalized nature of traditional American Indian belief.

The final way in which this dissertation explores community building from the Moravian perspective is through shared goals. Many of these goals related to the self-sufficiency of the group: did it have enough food and provisions to survive and thrive? Could it live out its faith, and provide for the mutual safety, education, and health? Both Moravians and Indians worked together to achieve some of these goals. They planted and harvested together, hunted together, sold baskets, brooms, skins, and tar for the economic growth of the community, and worshiped together. European brethren also promoted other goals, such as education (many older Indians would join in the classes that were for the children) and health (a European neighbor even sought out Brother Martin for his medical expertise). The Indians provided for other goals, like safety (Moravians were pacifists, but allowed their converts arm themselves for hunting and protection) and obtaining food through fishing.

The primary goal of the Moravian missionaries was the spiritual salvation of Indians. They did not try to convert other European groups, but instead focused on the souls of the 
American Indians. They risked their lives living in the frontier; they could have lived comfortably in the larger towns of colonial America, like many of their English counterparts. Instead, they lived in the thick forests among the American Indians, trying to convert them.

The Indians, on the other hand, generally seem more concerned with health (through food, medicine, and education) than their Moravian counterparts. Based on the diaries (which were, of course, written by the German missionaries) the Native Americans realized the importance of religious rhetoric to the Moravians. Thus, when requesting permission to remain in the mission village, they did so in formulaic ways that focused on religious desire rather than pragmatic reasons. I do not mean to indicate that the converts were not true believers of the Christian faith, but that they recognized the goal of the Moravians and used that recognition to meet their own goals.

To create and maintain strong connections, Moravians understood the importance of daily interactions. These interactions helped to maintain the community consciousness of the congregation. They were continually visiting and checking in on one another. Almost every day there are records of the white brethren 'visiting' with their Indian counterparts. These visits were not only with out-of-town Moravians (those who lived outside of the village), but diarists even recorded visits among those who lived within the village. Diarists considered these visits so vital that they recorded the daily meetings of neighbors. In my research, I have named these internal visits - the daily visits of neighbors that maintained existing bonds of friendship and faith. I have also made a note of external visits. These were visits of Moravians who live outside of the village, family, neighbors, and strangers. Many Moravians from Bethlehem and other Moravian mission towns visited the villages. Unbaptized Indians also visited the villages frequently. These visits were more comparable to family visitations that we continue to have today. Both visiting Moravians and visiting Indians came to the villages primarily to see their loved ones who lived 
there. Less frequently there were political visits and medical visits. These visitors came for specific purposes and did not necessarily contribute to the community building goals of the village.

By focusing on the issues that the entire community felt invested in, the Moravians were creating communities. The French, the English, and the Iroquois were each trying to use the enmities of the local indigenous population for their political gains. The Moravians, however, were attempting to unite disparate groups, and even groups of traditional enemies, to create cohesive Christian communities. Their goal was to unite the community on religious grounds rather than racial or tribal grounds. Whether or not the Moravian succeeded in this cohesion depends on one's parameters of success. Most of the villages they created are now American towns, with little Moravian presence, and no American Indians. Whether the Moravians thought they were successful is difficult to determine, since they were pleased with the number of converts they had, disappointed at those who left them, and always wanted to reach more. While they did not meet all their goals, we can compare them to other missionary groups and see that they made lasting conversions that created long friendships and built communities of faith, although imperfect. Thus, they were more successful than many of their counterparts, like the Lutherans, Presbyterians, and Quakers.

The Moravians faced several obstacles, but from 1754 to 1765 their community survived with several of the principal members still in leadership positions. By sharing culture, experiences, and goals, they created a strong bond that they forged in 1754. In this project, the most tension on their congregation was from 1763-1765 when the Pennsylvania government held the Moravians in Philadelphia. There they faced internal rather than external pressures. In Philadelphia the congregation began to crumble because they no longer shared the same goals, 
but once the government released them, their goals solidified, and the community began to work cohesively again.

This project is in two separate parts, which both revolve around one Moravian Native American community in eastern Pennsylvania. Part One consists of chapters one through three, with the focus on the creation, maintenance, and eventual destruction of the village of Gnadenhütten. ${ }^{23}$ Chapter One argues that the while the English, Iroquois, and French were fighting for political power in Pennsylvania's frontier, the Moravians found themselves caught between fulfilling their mission and facing the political pressure of the Iroquois and English to dissolve the community. Chapter Two argues that shared experiences, shared culture, and shared goals created community cohesion in a multi-ethnic village that was facing extreme external pressures. While the English and Iroquois were trying to tear apart alliances to strengthen their political power, the Moravians were working hard to maintain and create new alliances among Europeans and Native Americans. Chapter Three argues that the Moravians in Gnadenhütten had little desire to become involved in the political maneuvering of the frontier, and their hesitation in responding to Iroquois demands led to the attack on their village. The attack on the village of Gnadenhütten was the result of the community's refusal to become involved in political affairs.

Part Two begins in the years after the attack on the village of Gnadenhütten, but primarily focuses on the 'protective' internment of the Moravian Native Americans on Province Island and at the barracks in Philadelphia. It consists of chapters four through six, and the primary years are from 1763 to 1765 . Chapter Four argues that the hardening of racial lines from the Seven Years'

\footnotetext{
${ }^{23}$ Not to be confused with the village of the same name in Ohio, which Moravians established in the Revolutionary period, two decades after the destruction of the village we will explore.
} 
War caused the Moravian Indians to be more endangered after the war than they were during it, as evidenced through their petition for aid from the Pennsylvania colonial government. The riots and raids that continued after the signing of the Treaty of Paris in 1763 made the pacifistic Moravians targets for vigilante groups and unfriendly Native Americans. Chapter Five argues that the divisions between the Governor and the Assembly, and subsequently the rural and urban settlers, placed the Moravian Indians directly at risk. Many in the city were not pleased with the governmental decision to help the Moravians, and the tensions of the frontier led to tensions within the government, especially between the Governor and the Assembly. Chapter Six argues that the cohesion of the Moravians' community in Philadelphia was on the brink of breaking down due to the tensions inside the barracks that led to frustration in the congregation. The Moravians' experiences were causing a rift in goals, and until their release from the barracks, the cohesion of their community was in danger. Once the Governor allowed the Moravians to leave the city, they again shared the same goals and worked together for the betterment of the congregation. These chapters all enforce the larger argument: the intense violence in Colonial Pennsylvania during the 1750 s and 1760 s did not prevent the Moravians from building multiethnic communities, even as other groups (French, British, and Iroquois) pursuing their own political gains sought to tear such communities apart. 


\section{Part I: Gnadenhüitten}

Part I revolves around the communities of Meniolagomekah and Gnadenhütten during the years leading up to and at the beginning of the Seven Years' War. It contains three chapters that explore the creation and demise of these communities. Chapter one discusses the political background of the area in a period prior to war, and how the political power players were trying to exert power on the people in the village. It argues that the while the English, Iroquois, and French were fighting for political power in Pennsylvania's frontier, the Moravians found themselves caught between fulfilling their mission and facing the pressure of the Iroquois and English to dissolve the community. Chapter two focuses on creating the community within the village of Gnadenhütten, especially after the Delaware from Meniolagomekah were forced from their village and moved to Gnadenhütten. The community was facing tension at this time due to the start of the war, the changing demographics of the village, and decisions to remain at the village despite the warnings of outside groups. It argues that shared experiences, shared culture, and shared goals created community cohesion in a multi-ethnic village that was facing extreme external pressures. Chapter three explores the destruction of the village of Gnadenhütten, the reason for the attack, and the possible perpetrators. It argues that the Moravians in Gnadenhütten had little desire to become involved in the political maneuvering of the frontier, and their hesitation in responding to Iroquois demands led to the attack on their village. The attack on the village of Gnadenhütten was the result of the community's refusal to become involved in political affairs. 


\section{Pennsylvania Politics}

Chapter One argues that while the English, Iroquois, and French were fighting for political power in Pennsylvania's frontier, the Moravians found themselves caught between fulfilling their mission and facing the pressure of the Iroquois and English to dissolve their community, and focuses on the interactions between these larger political groups from approximately 1737 to 1754 . First, I explore the motives and influence of the large political players: the French, English, and Iroquois Confederacy. The chapter then focuses on how the political powers attempted to control and pressure the primary Native American groups in Pennsylvania which eroded the peace that had lasted in the frontier since the late seventeenth century. To conclude, I show how these interactions affected the Moravians and their American Indian brethren in Meniolagomekah and Gnadenhütten, two villages where Moravians and Native Americans lived together. These arguments are drawn from primary sources found in the Minutes of the Provincial Council of Pennsylvania and the communal diaries of Meniolagomekah and Gnadenhütten. The Provincial Minutes show that the English, the Iroquois, and to a lesser extent the French (aided by the Shawnee in the Ohio River Valley) were trying to move the Delaware, and to a lesser extent the Moravians and Mohicans from the Pennsylvania frontier.

The main source for this chapter, the Minutes of the Provincial Council of Pennsylvania, needs contextualizing to understand its positionality and bias. While the Council recorded them for the Governor and the Council's use, they bear an undeniable English worldview. For the purposes of this argument, I will be looking at the language and motivation of the Pennsylvania government. These records give us the words of Native American actors through an English lens, and there is no way to concretely establish that the English are portraying the Native Americans' 
words accurately. I am using the quotes as if they are accurate, unless there is refutation from another source, like the community diaries; this does not mean that we should not be cautious of their validity. The letters from negotiators, like Conrad Weiser, that recount the words of the Native Americans he encountered are even more problematic. Negotiators, by nature, needed to interpret and translate words and deeds to communicate between both parties. ${ }^{1}$ However, like with the direct quotes, there is no direct evidence that the negotiators were being duplicitous. Regardless, we should keep in mind that the Native American words and thoughts are coming to us second-hand. With that caution, I will try to explore the English motivation more than the Native American motivation - since the English motivation is more available while the Native American motivation is an English representation of their goals.

The English were aware of the tribal differences between groups like the Delaware, Shawnee, and Iroquois, but these provincial minutes do not go into any further detail about specific members of those groups, other than naming group leaders, which is an additional difficulty to consider when relying on the minutes as a source. The minutes, generally, referred to each group as monolithic entities: Delaware, Shawnee, etc. While using this source, it is important to remember that even among these groups there were those who did not agree with the actions or words of the others. Therefore, in this chapter I will be referring to these groups generically, but caution that these groups were still comprised of individuals. In the communal diaries there is more specificity_-points where we can see that this smaller group within the village achieved consensus, for instance. But, the minutes of the Council do not reach that level

\footnotetext{
${ }^{1}$ Merrell, Into the American Woods, 200-203.
} 
of specificity. These are the written sources that exist to examine the people described within them. I cannot ignore the fact that they are biased, and yet, I cannot fail to use them. Therefore, in the absence of other evidence that casts doubt on them, I will take the words at face value.

\section{Imperial Power and Motives}

The French, English, and Iroquois were the primary political powers in mid-eighteenthcentury Pennsylvania. Three aspects constitute a large political player: numbers (population), resources (capital or technological), and influence. The French had the resources, but not the numbers, and less influence in the region than the English. The English had the numbers and the resources, they were more influential than the French, but had less influence over the land than the Iroquois. The Iroquois had neither the numbers nor the resources but had more influence than the English and the French, especially given that European population was relegated mainly to cities, while the frontier was open and had more Native Americans than Europeans. ${ }^{2}$ Given these parameters, it seems natural that the English would become the primary power in the region in this period.

${ }^{2}$ Fred Anderson, Crucible of War: The Seven Years' War and the Fate of Empire in British North America, 1754-1766 (Random House LLC, 2007), xxiii-xxiv. According to Anderson the French had a population of about 55,000 while the British had about 1.1 million and 250,000 enslaved. 
France and Britain were both European powers fighting over control of the North American continent. France, ruled by King Louis XV, was trying to connect their colonial acquisitions to gain full control of the primary river system on the continent, the Mississippi. By controlling the smaller Mississippi tributaries, like the Ohio River, the French would be able to connect their lands in the north and south of the continent, thus expanding their markets. The Monongahela and Allegheny Rivers join at the confluence (modern day Pittsburgh) to create the Ohio River, and after an initial sixty miles or so northwest, it turns and travels southwest to the Mississippi. By building forts along the rivers, the French were hoping to create a permanent presence that would be used for river trade, connecting their imperial lands, French Canada and Louisiana.

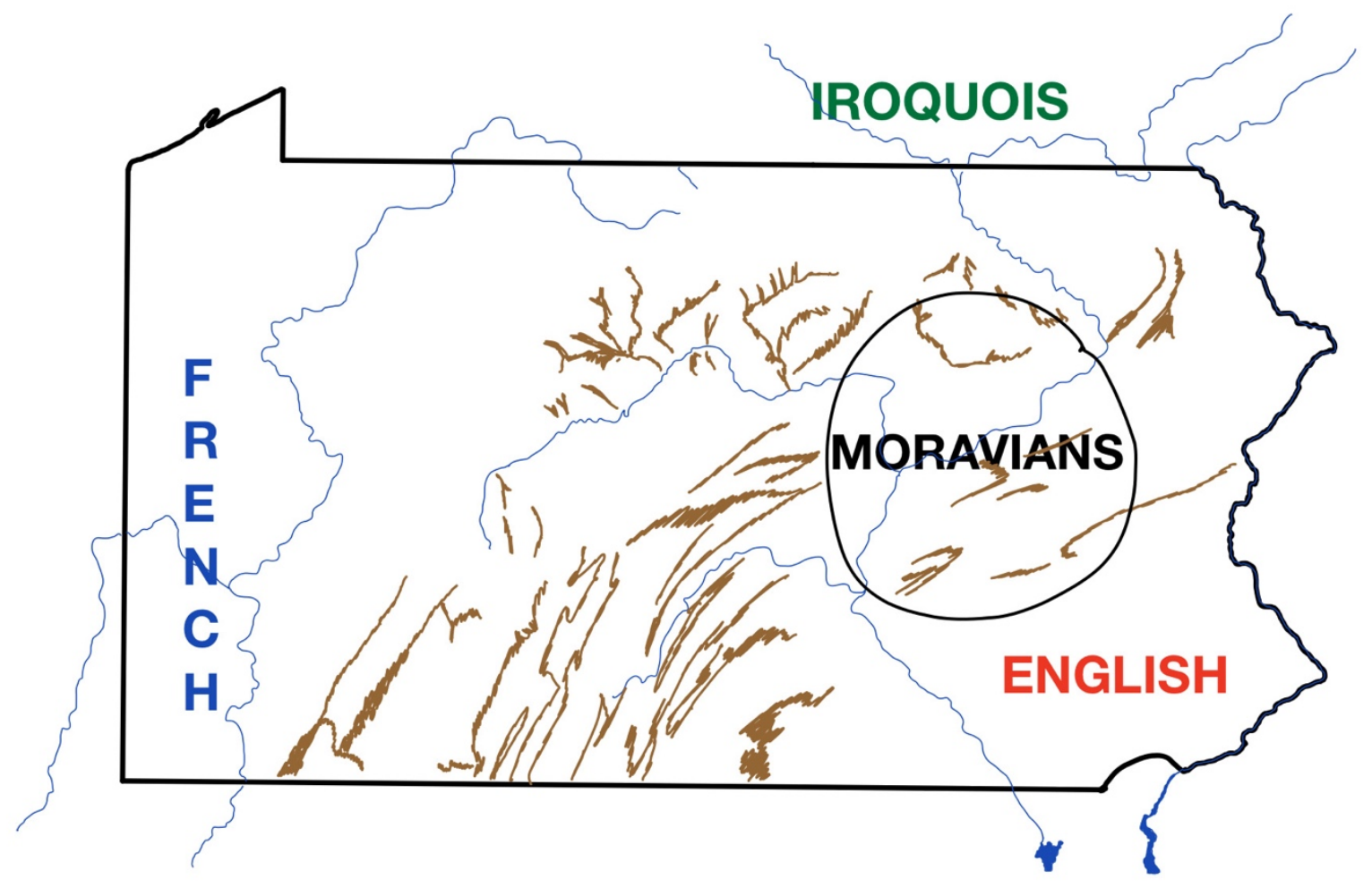

Figure 1: Political Players in Pennsylvania 1750s. Map by Megan McGee

Native Americans already populated the French lands in French Canada and the Ohio River Valley. France's primary Native American ally was the Huron, traditional enemies of the 
Iroquois. However, the French would also trade with the Iroquois, who initially remained neutral in the European imperial exploits. The English lands were to the southeast of the majority of the Iroquois Confederacy. The English began, as early as 1745 , to try to attract the military alliances of the Iroquois and their smaller allies against the French. By 1754, the English were also trying to create an alliance against the French with the Catawba and the Cherokee' two groups the Iroquois often raided and fought against. ${ }^{3}$

Unlike many European nations, American Indian nations were dependent on a mobile and flexible understanding of land ownership and use. These groups were not situated at a place indefinitely; instead, they raided, hunted, gathered, and planted in disparate places, all within the territory of their nation, but those territories may overlap. For instance, the Shawnee may have land in which they hunted, while Delaware women used the same land for gathering elderberries. ${ }^{4}$ The tribe did not own the land, instead tribes used it for a purpose. Because of this distinction many tribes were willing to use the land seasonally with other tribes. The arrival of the Europeans, however, introduced the ideas of land as a commodity, and changed the way that the Native Americans used land. Europeans halted the natural movement of the groups, since Europeans claimed land rights that did not vary for season or use, and led to large groups of displaced people. In Pennsylvania, by the 1700s, one could find multi-ethnic Indian towns where displaced groups lived together for protection and support from their European neighbors. Many of the tribes in Pennsylvania were refugees, having fled from other colonies and places due to violence. Pennsylvania was known to be the land of the Long Peace, and this peace was

\footnotetext{
${ }^{3}$ MPCP, (Harrisburg, PA: Pennsylvania, 1851), 4:776; Merrell, Into the American Woods, 168-69.

${ }^{4}$ William Cronon, Changes in the Land: Indians, Colonists, and the Ecology of New England (Macmillan, 2011), 63 .
} 
attractive to Native American groups who Europeans pushed out, forcefully or not, from their traditional lands. The territory's reputation for peace was due to the respect that William Penn had afforded the indigenous people, as well as the pacifistic nature of many of the colonists in the early history of the colony. Yet, the demographics of the earlier generations had changed from that era, and the peace would not last.

The largest Native American group in Pennsylvania during the 1750s were the Delaware. Traditionally from the Delaware River Valley, they had moved further west into Pennsylvania during the seventeenth century. They replaced the Susquehannocks and other smaller tribes who faced heavy casualty rates after the arrival of European diseases. The Delaware had a history of interactions with the Dutch prior to their first communications with the English. ${ }^{5}$ By midcentury English settlers effectively ousted the Delaware from their traditional land, much as the Delaware ousted the Susquehannocks. After the loss of their land, the Delaware people often lived in multi-ethnic cities, towns, and villages, like Shamokin, Wyoming, and Meniolagomekah in the eastern half of Pennsylvania.

The Shawnee were smaller and less politically influential than the Delaware. Traditionally their lands were in the southwest, but they moved into Pennsylvania due to the violence against them in the south. The Shawnee lived throughout Pennsylvania, but most of the Native American towns west of the Allegheny Mountains were Shawnee. Ohio River Valley land was virtually deserted in the century prior to the French and Indian War due to the destruction of the tribes that used the land traditionally, so the Shawnee had a large amount of territory to claim

${ }^{5}$ Paul A. W. Wallace, Indians in Pennsylvania (DIANE Publishing Inc., 2007), 18. 
when they relocated to the area. The Shawnee were loosely aligned with the Iroquois, generally following the lead of the much larger polity, yet often acting independently, as their changing alliances during the Seven Years' War prove. ${ }^{6}$

The French, English, and Iroquois were all exerting pressure on the colonists and the indigenous inhabitants of the land. Both the French and the English were attempting to seduce Native American peoples to their side of the fighting; the Iroquois were attempting to remove the Pennsylvania polities from European influence and cement them within the Iroquois sphere of influence. The records used in this chapter are from the perspective of the English and the Moravians who were residing on English claimed land, and these accounts showed the English and the Iroquois were worried about the growing presence of the French on the Ohio River Valley.

The Minutes of the Provincial Council of Pennsylvania suggest that the Iroquois control over the Shawnee and the Delaware was not total. As early as 1745 the Governor, George Thomas, and his council were warning the Iroquois about the actions of the Shawnee, and a Shawnee alliance with the French in the Ohio River Valley. At that point the French were not moving into the area full scale, but rather were trading with the Shawnee at their towns and creating a market presence. In 1745 the Provincial Minutes recorded that the Shawnee were attempting to pressure the Delaware to move west past the Allegheny Mountains. ${ }^{7}$ This movement would remove the Delaware further from the Iroquois and the English, and place them closer to the French. The Pennsylvania Governor and Assembly were critical of the

\footnotetext{
${ }^{6}$ Colin Calloway, The Shawnees and the War for America (Penguin, 2007).
}

${ }^{7}$ MPCP, 4:739. 
Iroquois and their power over the smaller Pennsylvania tribes, but they were also suspicious of French motives. The English wanted the Shawnee and the Delaware to fall under the supervision of the Iroquois but saw that there were tensions among the groups. The Pennsylvania colonial government had long wanted the Native Americans to move out of the contested land, at least since 1738, when Thomas Penn and the Governor's Council recorded that they wanted the Shawnee to move out of the Ohio River Valley to ally in force with the Iroquois. ${ }^{8}$ By moving these groups out of the contested land and consolidating them within the Iroquois territory, Penn thought the Ohio River Valley land would be open for European settlers, one of Penn's goals.

The English were aware of French goals in the Ohio River Valley, and by 1754 Governor James Hamilton, Thomas' successor as Pennsylvania Governor, began petitioning the Pennsylvania Assembly to provide funds for a militia. However, Quakers made up a significant portion of the Assembly, and were against using funds for military action. This disagreement within the Assembly eventually led to Virginia, with support from Thomas, raising a group to aid Pennsylvania's frontier against the encroachment of the French. In a letter to Hamilton, dated March 21, 1754, Governor Robert Dinwiddie of Virginia wrote of the French plan to build forts along the Ohio River. He informed Hamilton that he sent Captain William Trent to the confluence (modern day Pittsburgh) in January 1754, in order to build a fort and defend it against the French. ${ }^{9}$ Trent, however, would not be able to defend this fort; he lost it to a large French force in 1754 who expanded the fort and named it Fort Duquesne. ${ }^{10}$ This fort was later retaken

${ }^{8}$ MPCP, 4:90-91.

${ }^{9}$ MPCP, 6:4.

${ }^{10}$ MPCP, 6:28. There is a letter from George Washington to Governor Hamilton May 3, 1754, that tells of the French arrival at the fort. 
by the British and renamed Fort Pitt, after the Prime Minister, William Pitt the elder. By these actions, however, the Virginians were demonstrating that they were willing to fight for an Imperial presence in the valley — a position that Pennsylvania had not yet taken.

The English were not only trying to keep the Ohio River Valley out of the hands the French; there was also an internal struggle for the colonial control of the territory. These two colonies, Pennsylvania and Virginia, both claimed rights to the land based on English surveys and the charters. During a written exchange, from February and March 1754, between Hamilton and Dinwiddie concerning the logistics of a Virginia attack on the French in the Ohio River Valley, Hamilton wrote that he heard rumors that the Virginians were intending to remain and to settle on the land that they collectively hoped to keep from the French. ${ }^{11}$ In order to support Pennsylvania's claims to the land, Hamilton copied excerpts of two letters from Thomas Penn, the Proprietor, to himself. ${ }^{12}$ These letters, which were dated 1752, claimed that Penn agreed to allow the Virginians to build a fort on the land at the confluence of the rivers, but reminded both Governors that the land was Pennsylvania land, granted to the Penn family by the king. Penn, according to the excerpts, was willing to let Virginians settle on the land if they transferred the same rent and conditions they gave to Virginia to Pennsylvania. Hamilton continued in his own voice to ask for specifics of what Dinwiddie promised to his soldiers. He would suggest no less than two hundred acres per soldier, and not to limit the land to only the officers. ${ }^{13}$ In the next letter in the exchange, Dinwiddie did not acquiesce to Hamilton's suggestion, and instead argued that a surveyor would decide the matter of land ownership, regardless of Hamilton's proof, after

\footnotetext{
${ }^{11}$ MPCP, 6:3-4.

12 MPCP, 6:4.

${ }^{13}$ MPCP, 6:4-5.
} 
the fighting was finished. Given the fact that Virginia was providing troops and support for the frontier, there is little doubt that Dinwiddie expected the land. Not only did Dinwiddie deny Hamilton and Penn's assertion that the Ohio River Valley belong to the Penn's family charter, he also refused Hamilton the information that he was seeking about the compensation of land to the Virginia soldiers. ${ }^{14}$

This interaction between the two colonial Governors proved that they did not care about the Native Americans in their colonies, or their claims to the land. Neither man considered the thousands of Native Americans who were already living in the Ohio River Valley; instead the exchange showed that the English considered the land a commodity, and they were parceling it out to their citizens. Their goals were to remove the Native Americans from the Pennsylvania frontier and to relocate them north, under the political supervision of the Iroquois, in order to then sell the land to white immigrants who would pay rent and taxes to the government. As it stood, the displaced Native Americans, especially the Shawnee and the Delaware, were inhabiting the land that the colonies wanted, and were inhibiting them from taking full control of the frontier. If those groups moved north to the Iroquois, those lands would be open for European settlers without any contestation from Native Americans.

\section{The Break of the Long Peace}

The previous section focused on the larger scope of colonial politics, by examining the interactions of English colonies with the French, the Iroquois, and with one another. This section

\footnotetext{
${ }^{14}$ MPCP, 6:8.
} 
further explores the political tensions within Pennsylvania, including the interactions with the smaller Native Americans groups that the Pennsylvania government were trying to force north to the Iroquois. By the 1740s, the Long Peace of Pennsylvania was beginning to show signs of wear. In 1741 the Pennsylvania Governor's Council recorded that the Delaware complained that the English took their land without any payment. ${ }^{15}$ While the council did not mention the exact terms of the complaint, this undoubtedly concerned the Walking Purchase of 1737. For context, the council referenced a letter from the Iroquois which stated that the Delaware did not have the authority to sell the lands, as it was Iroquois territory. The question under consideration in the eyes of the council was to whom they should pay for the land, or who rightfully possessed the land before the English occupied it. They decided to mediate between the Delaware and the Iroquois, and let the Delaware know that the Iroquois would be in Philadelphia in May 1742 and suggested that they be present at the meeting. ${ }^{16}$

The Council's written decisions to mediate a resolution showed the rising tensions between the Delaware and the English, as well as between the Delaware and the Iroquois. The council responded:

It is the Opinion of the Board that a Letter from the Governor be sent to the Delaware Indians, setting forth the former Purchases and Releases of the said Lands and the request of the six Nations aforesaid, and Exhorting and requiring them (the Delawares) to live peaceably \& friendly with the English Inhabitants as

\footnotetext{
15 MPCP, 4:481.

${ }^{16}$ MPCP, 4:481.
} 
heretofore, And at the same time to inform them that as the Chiefs of the six Nations are to be at Philadelphia in May next, unto whom this whole Affair will be made known, The Delawares may, if they please, at their own Expence [sic], come down at the same time and be present. ${ }^{17}$

This indicates, first, that the English had written proof of their land purchases from the Delaware, or they had a convincing forgery. ${ }^{18}$ The Delaware claimed that English took the Walking Purchase, in which the Delaware lost thousands of acres, under false pretenses, but had no record of an initial treaty with William Penn (the original proprietor) that promised future amounts of land in the Delaware River Valley. The Delaware asserted that the claim to the Walking Purchase was false, the Penns provided forged papers about this claim to the land, and that they were cheated out of ancestral land. Secondly, the council minutes suggest that the English had the letter from the Iroquois which cast doubt on the Delaware claims of fraud and thievery. The Iroquois cited an agreement they had with the Delaware which stated the Delaware were unable to sell or transfer any land, as they were subservient to the Iroquois. The Iroquois refused to support the Delaware, which created a sense of betrayal and suspicion toward the Iroquois among the Delaware. Thirdly, here the English told the Delaware to live peaceably, as if their exhortations had more power over the Delaware than the Iroquois demands upon them. This indicates that the English saw themselves as more powerful than the Iroquois. And fourth, the council, Proprietor (Thomas Penn), and Lieutenant Governor (George Thomas), invited the Delaware to come to Philadelphia to defend their assertions against the Iroquois the following

\footnotetext{
${ }^{17}$ MPCP, 4:481.

${ }^{18}$ Merrell, Into the American Woods, 217. Forgeries of land deeds were not unusual.
} 
year. The English, therefore, were aware that any power the Iroquois held over the Delaware was not absolute, and they had decided to listen to both parties.

The Iroquois may have been the largest and most dominant Native American group in the region, but Native American politics were as complicated and complex as European, a fact that the English underestimated. In July 1742, Iroquois leaders, Delaware leaders, and English representatives met in Philadelphia about the Delaware complaints. Canasstego, an Iroquois chief, addressed the Governor and the Council. In his speech he blamed the Delaware for duplicity, siding with the English on the matter of the land purchase:

We see with our own Eyes that they [Delaware] have been very unruly People, and altogether in the wrong in their Dealings with You. We have concluded to remove them, and Oblige them to go over the River Delaware, and to quit all Claim to any Lands on this side for the future, since they have received Pay for them and it is gone through their Guts long ago. ${ }^{19}$

Then Canasstego turned and admonished the Delaware emissaries.

Let this Belt of Wampum serve to Chastize You; You ought to be taken by the Hair of the Head and shak'd severely till you recover your Senses and become Sober ; you don't know what Ground you stand on, nor what you are doing, Our Brother Onas' [the Proprietor of Pennsylvania] Case is very just and plain, and his Intentions to preserve ffriendship [sic]; on the other Hand your Cause is bad, your

${ }^{19}$ MPCP, 4:579. 
Heart far from being upright, and you are maliciously bent to break the Chain of ffriendship [sic] with our Brother Onas. We have seen with our Eyes a Deed signed by nine of your Ancestors above fifty Years ago for this very Land, and a Release Sign'd not many Years since by some of your selves and Chiefs now living to the Number of 15 or Upwards. But how came you to take upon you to Sell Land at all? We conquer'd You, we made Women of you, you know you are Women, and can no more sell Land than Women. Nor is it fit you should have the Power of Selling Lands since you would abuse it. ${ }^{20}$

In this speech, the Iroquois, in the presence of the English, further limited the Delaware. They demanded that the Delaware either move to Wyoming (Wajomick) or Shamokin, two Indian towns where the Iroquois had strong political ties. "We, therefore, Assign you two Places to go - either to Wyoming or Shamokin. You may go to either of these Places, and then we shall have you more under our Eye, and shall see how You behave."21 They also told the Delaware that they no longer have any rights to sell land, in perpetuity, and then Canassatego told the Delaware to leave the conference.

This reprimand of the Delaware by the Iroquois displayed the power of the Iroquois as well as the dependency of the Delaware. This political influence, however, not mean that the Delaware were going to submit to the Iroquois. Many Delaware felt that the Iroquois, to whom they should have been able to turn for help, had chosen the side of the English against them. Additionally, this speech showed the importance of written treaties, as they could be used to

\footnotetext{
${ }^{20}$ MPCP, 4:579.

${ }^{21}$ MPCP, 4:580.
} 
legitimate past agreements and mediate current disputes. The Iroquois mentioned a treaty written and signed fifty years prior, the same treaty that the Delaware were disputing. It is evident that the Iroquois were using the English written treaty as proof of a formal agreement. Agreeing to the English claim supported the overall Iroquois political goal: removing the smaller tribes out of the contested land of Pennsylvania. This strongly suggests that the Iroquois did not care to question the validity of the English statement, especially since they shared the same goal for the land in question.

The proposed Iroquois solution was for the Delaware to move from the disputed land to an area further north where they would be under Iroquois supervision, the same solution the English sought. It is likely that the Iroquois feared the Delaware would violently retaliate against the English who were squatting on the land and hurt Iroquois relationships with the colonists. In order to exert political pressure over the Delaware, the Iroquois wanted them to live within their sphere of influence. At this point we can see a distinct difference in the aim of the Delaware: to remain in their traditional lands; and those of the Iroquois: to remove the Delaware to towns with Iroquois dominance. The Delaware, despite the urging of the Iroquois, did not immediately move en masse, but instead chose where to live on an individual basis. Of the two villages the Iroquois suggested, Shamokin and Wyoming, Shamokin was a large urban center that was home to hundreds of indigenous people, under the political supervision of the Iroquois. ${ }^{22}$ Shamokin was primarily made up of Delaware, Tutelos, and Iroquois, while Wyoming was primarily held by Shawnee and Nanticokes under Iroquois supervision. ${ }^{23}$ These multi-ethnic towns and cities

\footnotetext{
${ }^{22}$ Merrell, Into the American Woods, 25.
}

${ }^{23}$ Merritt, At the Crossroads, 2011, 29. 
pledged allegiance to the Iroquois, and also acted on Iroquois behalf with their English neighbors.

On April 22, 1743 the Council met and examined a letter from Conrad Weiser, a Moravian cultural negotiator, which explained a ceremony that took place in Shamokin on April 9, 1743, with Weiser as representative of the English. ${ }^{24}$ In this ceremony the Iroquois leaders, Shikellimo and his son Sachsidowa, presented wampum to Weiser and representatives of the Delaware and Shawnee. With the wampum, they thanked the Governor Thomas of Pennsylvania for the kindness the colony showed the Iroquois after Virginians attacked and killed some of their warriors. The Iroquois claimed that they were innocent of aggression and that the Virginians acted out in unprovoked violence.

The Iroquois speaker, Sachsidowa, went on during the ceremony to chastise the Delaware, who he said were lying about English intentions to sow discord among the indigenous communities:

Cousins, the Delawares: We are informed you can talk a little English, by which you Pretend to have heard many things amongst white people, and you frequently bring Lies amongst the Indians, and you have very little Knowledge and Regard for Treaties of ffriendship[sic]; you give your Tongues too much Liberty. This String of Wampum serves to tie your Tongues and to forewarn You from Lies. ${ }^{25}$

\footnotetext{
${ }^{24}$ MPCP, 1851, 4:646.

${ }^{25}$ MPCP, 4:649.
} 
Next the Iroquois leaders turned to the Shawnee and accused them of believing the lies of the Delaware too readily:

Brethren, the Shawnees: You believe too many Lies, and are too forward in action. You shall not pretend to Revenge our People that have been killed in Virginia. We are the Chief of all the Indians. Let your Ears and Eyes be open towards us, and order your Warriours to stay at home as we did ours. ${ }^{26}$

Sachsidowa next addressed Brother Onas (the title the Iroquois used for the Governor of Pennsylvania) again. He warned Thomas that the English colonists were becoming violent and were believing lies against the indigenous people of the land. "Your Back Inhabitants are People given to Lies and raising false Stories. Stop up their Mouths; you can do it with one word. Let no false Stories be told; it is dangerous to the Chain of ffriendship [sic]." 27 Weiser told the council and Thomas that at the dinner following the meeting with the Iroquois, Shikellimo reported he also sent wampum to the Indians on the Susquehanna to remind them of the treaty that was created in Onondaga, and urged them not to go to Virginia in revenge.

The same day, April 22, 1754, the Governor received a belt of wampum from Olumpias, Chief of the Delaware, given to the Governor by Sachsidowa. ${ }^{28}$ With the wampum, Sachsidowa recited the Delaware speech. He told the Governor and the Council that the Delaware were peaceful, and the last thing they wanted was warfare through their land, which was situated like a buffer between the Iroquois and Virginia. It is important to note that Sachsidowa was the son of

\footnotetext{
${ }^{26}$ MPCP, 4:649.

${ }^{27}$ MPCP, 4:648-50.

${ }^{28} \mathrm{MPCP}, 4: 650$.
} 
an Iroquois leader, yet, he brought the wampum and recited the speech on behalf of the Delaware. He did this even after the Iroquois admonished the Delaware for gossip, and the English for not controlling their frontier settlers; this action indicated that the Iroquois and the Delaware were sincere in their desire for peace. Otherwise, what motivation would Sachsidowa have in bringing the wampum and words from the Delaware, words of peace after admonishment? The next day Thomas replied that he was pleased with the answers of all the Nations. He recognized the position the English and the Iroquois placed the Delaware in, and pledged to send a message of peace to Virginia, to which he expected an amicable response. ${ }^{29}$

First, the Long Peace was beginning to wear. The metaphor of the chain of friendship was a recurring theme between the Iroquois and the English, and it was a chain that had to continually be polished and repaired. ${ }^{30}$ The chain connected the Iroquois to the English, but both parties were aware that their relationship depended, in part, on the actions of other players: the Virginians, Delaware, Shawnee, and smaller political players.

Second, based on the English records, it appears that the Iroquois blamed the Delaware as the group that spread lies among the Native Americans, and painted the Shawnee as impetuous younger brothers who did not want to listen to reason. It seems that the Iroquois attempted to discredit the Delaware by accusing them of lying. It is interesting that the Iroquois would assert this, given that they were promoting English written treaties over their own cultural forms of negotiation as proof, which could eventually undermine their own political treaties, which also relied on wampum and oral agreements. Of course, these Iroquois words are reported to us

\footnotetext{
${ }^{29}$ MPCP, 4:651.

${ }^{30}$ James Merrell, Into the American Woods, 411.
} 
through the Provincial Minutes and the words of Weiser, and not from their own sources, a fact that will always make the work of historians more difficult. Critical viewing of the sources is necessary, but I find little evidence not to take these accounts at face value. There is ample evidence, however, through tribal actions of the rift between the Delaware, Shawnee, and Iroquois.

Third, the Delaware, though an Iroquois leader, extended their own wampum and message to the Governor and council — a sign that the Iroquois placed a certain amount of responsibility on the English for the tensions. The Shawnee did not address the Governor and Council, but the Delaware did. This indicates that the Delaware were aware of the importance of the relationship between the two, larger powers, and did not want caught in the middle. Strategically, the Delaware assured the Governor and the Council that they were aware of their place and did not want any warfare on their land.

Fourth, we can see that the Iroquois assumed that the Governor and the Council had authority and power over the European immigrants who lived beyond the city borders in the frontier. The Iroquois claimed that they told their subjects to stand down and do no violence, and they expected the Pennsylvanians to do the same. This assumption of English control was false. Just as the Iroquois had little success controlling the Delaware and Shawnee in Pennsylvania, the English had trouble controlling the traders and farmers who lived in the Pennsylvania frontier. Tales of white men who cheated Native Americans, sold them alcohol illegally, raped their wives, and squatted on their land fill the council minutes. ${ }^{31}$ The council was aware that the

\footnotetext{
${ }^{31}$ MPCP, 4:571-72.
} 
European frontiersmen, including their own negotiators, were scamming the local Native American groups. ${ }^{32}$ The Iroquois said that their quarrel was with Virginia, not Pennsylvania, and that until Virginia removed the hatchet, they could not bury it. (In Iroquois tradition it was the person or nation that began the violence that had to come and petition for peace.) They also told the council that any raiding parties would move into Virginia around the Pennsylvania settlements, and would not disrupt the Pennsylvania colonists, which showed they recognized the Pennsylvania government as separate from the Virginia government.

Fifth, the Governor and Council responded to the Iroquois first, saying that they would send a message immediately to the Virginian Governor. Only after that message did they address the Delaware Chief, Olumpias, telling him that they were sorry that the Iroquois blamed the Delaware for the trouble and tension on the frontier, but to remain vigilant against lies among the Indians. This response showed that the English were trying to maintain friendships and diplomacy between all three groups, while recognizing the grievances of the Iroquois, and the allegations against the Delaware, but not necessarily taking sides. They promised the Delaware that they would maintain the chain of friendship, a promise that they would not keep.

How long would the peace from this treaty last? In 1744, the Delaware murdered an English colonist, Jack Armstrong, the French declared war on the English, and the colonies of Pennsylvania, Virginia, Maryland, and the Iroquois made a new treaty. ${ }^{33}$ This treaty would not last either, especially as France was expanding in the west. During the next decade the tensions among these groups continued to grow—-the Iroquois continued to demand acquiescence from

\footnotetext{
32 Jane T Merritt, "Cultural Encounters along a Gender Frontier: Mahican, Delaware, and German Women in Eighteenth-Century Pennsylvania," Pennsylvania History 67, no. 4 (October 2000), 172.

${ }^{33}$ MPCP, 1851, 4:680, 682, 698.
} 
the Delaware, the Delaware continued to assert their independence from the Iroquois, and the English continued to listen to both sides, while placing more effort into their relationship with the Iroquois.

The politics of Pennsylvania, as described above, were complicated as two European, two colonial, and several Native American groups vied for the same territory. The largest factions wanted to remove the smaller Native American groups from contested lands on the frontier. These factions created alliances as well as enemies as they fought for control of the lands to the west of the Appalachian Mountains, and most importantly in the Ohio River Valley. While the villages of the Moravians were east of the Appalachian Mountains, the violence of the Seven Years' War did not remain west of the mountains. The violence of these alliances and enmities, along with the imperial, racial, and ethnic divides that were created, threatened all the inhabitants of Pennsylvania who lived on the frontier, including the created communities of the Moravian Indians.

Two of these Moravian Christian communities were the villages of Meniolagomekah and Gnadenhütten. Iroquois, the English, and other smaller Native American groups-including the Shawnee - pressured these two villages to either move or ally with one of them. The Moravians, on the other hand, did not politically pressure their converts. Instead of trying to force their converts to act in the Moravians' interests, the Moravians allowed their indigenous converts to make independent decisions. The next section will look at these two villages, Meniolagomekah and Gnadenhütten, their history, the pressure the Iroquois and English exerted on them, and the creation of a larger village at Gnadenhütten.

\section{Pressure on the Villages}

\section{Meniolagomekah and Gnadenhütten}


Meniolagomekah was an existing Delaware town where American Indians invited Moravian missionaries to live in $1750 .{ }^{34}$ Gnadenhütten, on the other hand, was a Moravian mission town, created in 1746 by the Moravians to be home to Christian Mohicans who were displaced from their traditional homes due to the extensive immigration of white settlers. ${ }^{35}$ Following Schmick's timeline in Pennsylvania missions, this dissertation begins research with the 1753 diary from Meniolagomekah, the earliest mission where Schmick was active. Meniolagomekah was where a majority of Delawares lived before Richard Peters, the Governor's Secretary, forced them off the land in 1754. The 1754 diary is from Gnadenhütten, where Schmick was the primary missionary, and records the backlash from the Meniolagomekah eviction, the introduction of the Delaware into the daily life of the Mohicans of Gnadenhütten, the eventual creation of a larger town on the Mahoni Creek, and the continued "unusual circumstances" (outside pressure to leave) of the village when it came to American Indian politics. This section will explore the background of these two villages, and then examines movement between the two villages. I conclude by examining the consequences of the English

${ }^{34}$ Jane T. Merritt, "Dreaming of the Savior's Blood: Moravians and the Indian Great Awakening in Pennsylvania," The William and Mary Quarterly 54, no. 4 (1997), 728.

${ }^{35}$ Merritt, "Cultural Encounters along a Gender Frontier", 96, 129. 
land claims on Delaware land, which caused the Delaware in Meniolagomekah to choose what to do with their village, and the culture and community they had made.

\section{Early Moravian Missions in Eastern Pennsylvania \\ \& Surrounding Areas 1740-1773}

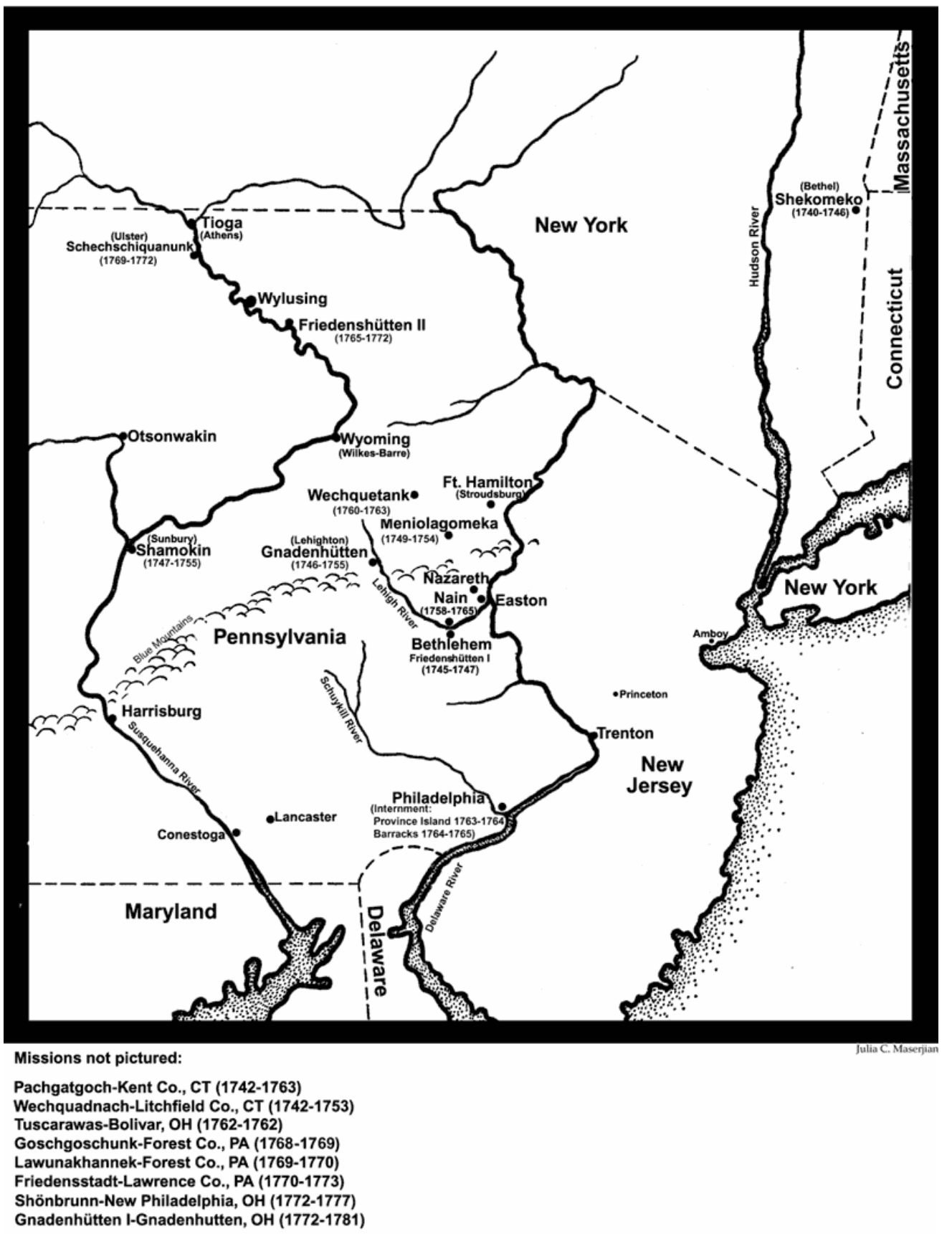

Figure 2: Early Moravian Missions 1740-1773. 


\section{Meniolagomekah}

Meniolagomekah, as noted, began as a Delaware village in the eastern part of Pennsylvania between the Lehigh and Delaware Rivers. The Delaware were a group English settlers displaced from the Delaware River Valley, who then moved west into Pennsylvania in the latter half of the seventeenth-century. ${ }^{36}$ This group was composed of the Leni Lenape and several smaller tribes (the Munsees, Unalachtigos, and Unamis) and became known, collectively, as Delaware. They built this town on an Indian path which connected them to other Native American towns and villages. Indian paths crisscrossed Pennsylvania and correspond well to the modern highway system. ${ }^{37}$ As Merritt pointed out, it was not the position of the town on the path that made the town important, rather it was the use of the path to maintain relationships between disparate communities. ${ }^{38}$ The Delaware, as we can see from their place on this traveling path, were connected with the Iroquois, the English, the Moravians, and other, smaller tribes in the Pennsylvania frontier.

In 1742 Nicolaus Ludwig von Zinzendorf, Moravian spiritual leader visited the town of Meniolagomekah when travelling through Pennsylvania to create connections with Native American communities. He wanted to create ties to the village, bringing them into Bethlehem's economy, and hopefully into the congregation. ${ }^{39}$ Many of the Delaware did convert to the Moravian faith. Yet, the Delaware converts maintained connections their unbaptized neighbors

${ }^{36}$ Wallace, Indians in Pennsylvania, 18. It is difficult to determine when exactly the Delaware moved north to the lands between the Blue Mountains and the Delaware River. But by 1675 when the Susquehannocks were mostly pushed out of Pennsylvania, the land was open for Delaware migration.

37 Wallace, 44. "Many of our modern highways follow the general course of Indian paths, but differences in travel objectives and weight of traffic (today's trucks as compared to yesterday's moccasined men and women) have made it impossible for our roads to follow the old paths for any distance."

${ }^{38}$ Merritt, "Cultural Encounters along a Gender Frontier", 33.

${ }^{39}$ Merritt, At the Crossroads, 89. 
and family members, which gave them more cultural freedom than their Gnadenhütten counterparts. Instead of converting to Christianity and taking on German Moravian culture wholesale, the inhabitants of Meniolagomekah had Christians and non-Christians living together and maintaining their own cultural traditions. By 1747, the Delaware in Meniolagomekah were aware that Mohicans were living in Gnadenhütten with the Moravians, who were not historically friendly with the Delaware. The Moravian village was only eight miles away, making it the closest village to their own. ${ }^{40}$ This nearness affected the amount of travel between the two villages. By 1753 Meniolagomekah traded directly with the brethren in Bethlehem, and the leaders of the village, including Memenowal, actively visited the Moravian town. ${ }^{41} \mathrm{By}$ connecting themselves to the Delaware town, the Moravians were also connecting themselves with the larger Native American community.

In 1753, Abraham Büninger was the primary missionary in Meniolagomekah. Brother Schmick, the linchpin of my research, was a lower level missionary who would become more influential in Gnadenhütten. Büninger and Schmick wrote the communal diary for the village of Meniolagomekah. These diaries recount the daily lives and activities of the missionaries and their Native American neighbors and converts. Schmick, while working under Büninger, often travelled from village to village getting provisions and visiting other Moravians. This is the only year from the diary research Schmick himself was not the primary recorder of the communal diaries.

\section{Gnadenhütten}

\footnotetext{
${ }^{40}$ Merritt, 90.

${ }^{41}$ Merritt, 90. Moravians baptized Memenowal and named him Augustus in 1749.
} 
Moravians established Gnadenhütten in 1746 to take advantage of the Indian travel that passed along the paths. They strategically placed it upon a well-known path, approximately eight miles to the west of Meniolagomekah, and the Moravians invited displaced Mohicans to live there with them. ${ }^{42}$ Foresight allowed the Moravians to encounter many 'foreign' Indians whom they would not have met in Bethlehem. Bishop Cammerhoff, in 1747, wrote to Zinzendorf that "the Wyoming Path is here, and many strange Indians pass over it, and are thus brought to Gnadenhütten - they frequently attend our meetings." ${ }^{23}$ The diaries record several visits from foreign Indians who stayed overnight and attended the service of the Moravians, proving that strategic placement of the village introduced unbaptized American Indians to the missions and their efforts.

Moravian missionaries closely monitored the Mohicans. To live within the village, the Mohicans had to accept economic and social rules, limitations that the Meniolagomekah Indians did not have. Moravians created and enforced these rules to support Moravian ideals. Merritt showed that while the Native American groups who lived in the village accepted some of the social rules, like sexual control, they were also likely to ignore others, such as limiting extended family networks, especially those outside of the faith. ${ }^{44}$ This created a synthesized community that was neither fully Moravian nor fully Mohican.

Schmick was the recorder of the Gnadenhütten communal diary of 1754, which, like the diary of 1753, recorded the daily lives and encounters of the Moravians and their Native American counterparts. Unlike the 1753 diary from Meniolagomekah, there is significant outside

\footnotetext{
${ }^{42}$ Merritt, 96.

${ }^{43}$ Merritt, 132.

${ }^{44}$ Merritt, "Cultural Encounters along a Gender Frontier".
} 
Moravian interaction with the village of Gnadenhütten. This is not surprising as the Moravians created Gnadenhütten to preach to the Native Americans, while Meniolagomekah was an Indian village where a few Moravian missionaries happened to live. Moravian leaders from Bethlehem visited Gnadenhütten to ensure their mission project was progressing. During the year Moravian leaders often visited with their braune Geschwistern (brown siblings/brethren) to see how they were maintaining their Christian lifestyle. Unlike the village of Meniolagomekah, which was primarily an Indian town that saw more Native Americans than Europeans, both groups (Moravian and Native American) visited the village of Gnadenhütten regularly.

While many of the Native American villages in Pennsylvania were not long-standing village centers, due to the nature of eighteenth-century displacement, the trade routes upon which they were located were centuries old. These paths, like highways today, connected trade, but also connected extended families and friends. ${ }^{45}$ Many men used these trails for hunting, but women also used these trails. Merritt noted that women in Meniolagomekah were using these trails to maintain contacts with relatives and neighbors, as well as to participate in the new market economy. ${ }^{46}$

The land where these villages were located, near the Lehigh and between the Blue Mountain ranges, like much of Pennsylvania frontier land, was a commodity. The Delaware and the Moravians were well situated within the colony, relatively close to the urban center of Philadelphia, close to the town of Bethlehem, and close to Native American villages and towns. This land was prime real estate. By 1754, the Provincial Secretary of Pennsylvania, Richard

\footnotetext{
${ }^{45}$ Merritt, At the Crossroads, 33.

${ }^{46}$ Merritt, 151.
} 
Peters, had forced the Delaware off their land, and claimed it as his own. ${ }^{47} \mathrm{With}$ this event, the Delaware from Meniolagomekah had to choose between several options. They could move to the Susquehanna River Valley, bowing to Iroquois pressure, move to Gnadenhütten to live with the Moravians and their Christian Mohicans, or move further west. Research indicates that the Delaware continued to be pressured by the Iroquois to move closer to their sphere of influence, while the Iroquois did not respond to this encroachment of the English; instead the Iroquois continued to pressure, as they had been arguing for over a decade. The diaries from 1753 and 1754 showed several instances of this external pressure, which we will further explore in the next section.

Movement Between the Villages

Regardless of any tribal animosity, inhabitants of Meniolagomekah and Gnadenhütten visited each other regularly. ${ }^{48}$ While this may have been due to necessity (the nearness of the villages was useful when they needed provisions), there were times when individual Native Americans went to the other village for friendly visits, suggesting actual multi-ethnic friendships across these political divides. Delaware visited Gnadenhütten regularly, and Mohicans visited Meniolagomekah just as regularly. In 1753 there were sixty-six instances of recorded movement between these two villages. ${ }^{49}$ In the Gnadenhütten diary of 1754 there were thirty-nine records of village interaction but given the fact that the two villages consolidated in the end of April 1754,

${ }^{47}$ Merritt, $159-60$.

${ }^{48} \mathrm{MAB}$, MissInd 1.18.122.3, MissInd 1.11.118.1. The community diaries from 1753 and 1754 show numerous interactions between the two villages.

${ }^{49} \mathrm{MAB}$, MissInd 1.18.122.3. 
it is not surprising that there were fewer instances of visitations. ${ }^{50}$ The final Gnadenhütten diary entry about Meniolagomekah was in June 1754.

While the indigenous people of the villages external faced external pressure, the Moravians had acquired more land in 1754 and were planning on building a larger and more diverse Indian village. This purchase coincided with the Delaware removal from Meniolagomekah, allowing the Moravians to strengthen their bonds with the other local tribal groups. The Mohicans at Gnadenhütten were prepared and expected to move to the new city, which the Moravians created for them. The Delaware, unlike the Mohicans, asked the Moravians for permission to reside in the new city and become members of their new community. The Moravians gathered and discussed the options and decided to open the new city to the Delaware. $^{51}$

\section{English Land Claims on Native American Land}

The Iroquois were fairly direct in pressuring the Native Americans in the villages to move. They, or their representatives, would visit the villages, reminding the villagers of previous agreements that would move the Native Americans to Shamokin or Wyoming. ${ }^{52}$ The English were less direct with their pressure. Instead of sending representatives to the villages, they relied on treaties with the nations involved, and on the pressure of the Iroquois. The Moravians, while accepting that some of their converts were going to leave due to the political pressure of the time,

\footnotetext{
${ }^{50} \mathrm{MAB}$, MissInd 1.11.118.1.

${ }^{51}$ MAB, MissInd 1.11.118.1,

${ }^{52}$ MAB, MissInd 1.18.122.3, MissInd 1.11.118.1, MissInd 1.11.118.2.
} 
also tried to get their charges to stay. They were worried that without the constant interaction of Native American and Moravian brethren, their braun Geschwistern (brown brethren) would forget the word of God and revert to heathenism.

In 1753 Brother Büninger, as the primary Moravian diarist for Meniolagomekah, wrote about a political visit from outside Native Americans. ${ }^{53}$ In March 1753, Büninger travelled with Shawnee and Nanticokes to Bethlehem, the Moravian city approximately sixty miles north of Philadelphia. He returned to Meniolagomekah with a young Shawnee man and talked with his congregation about the specifics of the visit. Once the young Shawnee left, the Shawnee sent a string of wampum with Brother Augustus (Memenowal, Delaware) to Gnadenhütten . The Nanticokes and Shawnee wanted an answer to a question that was unrecorded in the community diary. It is probable that the question was whether the Native Americans at Gnadenhütten (and Meniolagomekah) would leave the eastern frontier. Shawnee and Nanticokes were both tribes that lived in the villages of the Iroquois, either Shamokin or Wyoming, so it is probable that they came as emissaries of the Iroquois. However, there is also evidence that the Shawnee in the west were allying themselves with the French, so it could be that this question was not given from the Iroquois, but rather from the Shawnee themselves. Brother Augustus went to Gnadenhütten to ensure that both of the villages would give the Nanticokes and the Shawnee the same answer. ${ }^{54}$ The Moravian Indians at Meniolagomekah and Gnadenhütten did not hurry in their decision making, despite the pressure and 'unusual circumstances' recorded in their letters and communal

${ }_{53}^{53}$ MAB, MissInd 1.18.122.3, March 26-28, 1753.

${ }^{54}$ MAB, MissInd 1.18.122.3, March 26-28, 1753. 
diary. By 1754, when the Delaware were forced off of their land by Robert Peters, they had not made any distinct decisions.

Diaries from 1754 have more entries than the prior year referencing the pressure placed on the Native Americans. One entry from Gnadenhütten specifically recorded the opinion of Abraham (Shabash, Mohican), who spoke of a prior treaty with the Nanticokes and Shawnee and a desire to keep the peace. He said that that the Indians from Gnadenhütten had promised to move to Wyoming. ${ }^{55}$ This diary entry also recorded that Abraham was given the answer he desired by the other Indian brothers after a bit of reflection. From an earlier entry, we know that Abraham wanted to go to the Indian village, Wyoming, one of the villages the Iroquois suggested. Abraham feared that since the villagers had promised the Nanticokes and Shawnee that they would leave the village, there would be retaliation if they did not fulfill their promise:

In the late morning Brother Martin spoke with old Abraham, who, among other things, told him that his thoughts were stronger to go to Wajomick (Wyoming) than stay in Gnadenhütten, and that because he had promised the Nanticoke and Shawanohs, he feared that something bad would come out if they did not leave. ${ }^{56}$

Several Moravian Indians joined Abraham when he and his wife Sarah left the village. According to the diaries, Sarah wept because she knew that she would miss her sisters in Christ, but she assured the members of the village that she would not forget the holy words of the Savior. ${ }^{57}$

\footnotetext{
${ }^{55}$ MAB, MissInd 1.11.118.1, March 11, 1754.

${ }_{56}$ MAB, MissInd 1.11.118.1, March 1, 1754.

${ }^{57}$ MAB, MissInd 1.11.118.1, April 24, 1754.
} 
This movement of Mohicans coincided with the forced removal of the Delaware in Meniolagomekah. The villagers of Meniolagomekah, as previously noted, were forced off their land by Provincial Secretary of Pennsylvania, Richard Peters. There is no account of this event in the Provincial Minutes, but the Gnadenhütten diary recorded the following details. On April 26, 1754, Joshua's wife, Agnes, came with the news that a man came to the village of Meniolagomekah, and demanded that they vacate his land. Whether this man was Peters himself or a representative of his is unknown. Brother Augustus, after hearing the news, requested a white and Indian brother from Gnadenhütten go to Meniolagomekah for advice the next morning. The man needed their answer the next day. ${ }^{58}$ Early the next morning Brother Martin and several of the Indian brothers left for Meniolagomekah with the happy news that the Indians could move to Gnadenhütten. They returned later in the day, with the news that Brother Augustus and the other Brethren were very happy and thankful for the dear offer and the permission to go to Gnadenhütten, because they already aware of where they might be able to go. Immediately afterward, Brother Augustus informed the country man (Peters) that they agreed to vacate the land within eight days. He and the man (Peters) agreed that the Indians would receive five pounds of gold after they left the land. Merritt, who recounted this exchange, wrote that the pounds were given to the Delaware for the improvements they made on the land; the diary recorded that Peters gave the five pounds because of the effort that was made, presumably the effort of the Delaware to evacuate the land quickly. ${ }^{59}$ The Moravians in Gnadenhütten gave

${ }^{58}$ MAB, MissInd 1.11.118.1, April 26, 1754.

${ }^{59}$ MAB, MissInd 1.11.118.2, April 27, 1754. "Der Mann hat es dann auch gleich accordiert und ihm eine sichern Anweisung gegebe, wo er das Geld nach geschehene Abziehen von der Plaz empfangen soll.", "Gleich darauf hat Bruder Augustus dem Mann des Landes versprochen den Plaz mit seinen Geschwister innerhalb 8 Tagen 
praise to God that they were lucky enough to have the extra land that allowed them to accept the Delaware flock. ${ }^{60}$ Not all of the Delaware moved to Gnadenhütten, however; some of them likely gave into the Iroquois pressure and moved to the Susquehanna River Valley, away from the Moravians.

By the end of April 1754, the Moravians consolidated these two villages. Whereas before the Iroquois and the English were trying to pressure two separate villages and communities, now they had only one village with which to contend. The English, through Peters, forced the Delaware village out of their territory—it is evident that they chose to pressure the Delaware rather than the Mohicans, who were only a few miles away. It is possible that the English viewed Meniolagomekah as more vulnerable since the inhabitants did not have as strong connections to Europeans as their counterparts living in Gnadenhütten. The Mohicans in Gnadenhütten also had the added benefit of having another European group, the Moravians, as a cultural benefactor. The Iroquois had not come to the defense of the Delaware decades prior to the eviction of the village of Meniolagomekah, so there was little reason to expect they would come and aid the Delaware now, especially given that the move coincided with the political desires of the Iroquois.

After the move from Meniolagomekah to Gnadenhütten, the Delaware who left the area for the Susquehanna were no longer under the direct supervision or even the guidance of the Moravians, or any European group. By moving to the Susquehanna River Valley, they placed themselves in an area that was more Native American in population. The Iroquois would have considered these Delaware more easily controlled and contained, since they lived in an area of

völlig zu räumen, wenn er ihnen vor der gehabte Mühe die fenien zu machen 5 pfunden geldes geben wolte.”;

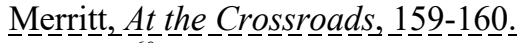

${ }_{60} \mathrm{MAB}$, MissInd 1.11.118.1, April 28, 1754. 
direct influence of the Iroquois Confederacy. The Delaware who decided to remain with the Moravians in Gnadenhütten, mostly already baptized Christian Delaware, were leaving their relative freedom behind. They had to accept that their role in the new, larger, village would be shared by the Mohicans and the European Moravians. It was the Delaware who had to adjust the most in the newly configured village.

\section{Conclusion}

Given the rising tension between the imperial powers and the colonial and indigenous inhabitants of Pennsylvania in the 1740s and 1750s, the Iroquois and the English were invested in removing the Native Americans from the Pennsylvania frontier. The Iroquois wanted to maintain control over the smaller indigenous groups, the English feared the Native Americans would retaliate against the colonists they no control, and they both wanted to keep their groups away from the French in the east. The smaller groups the Iroquois and the English wanted to control resisted the demands of the larger powers. Iroquois and English targeted Native villages for removal. The indigenous village members in Meniolagomekah and Gnadenhütten were being pressured by the Iroquois, and forced by the English, to leave their homes. Their Moravian neighbors were willing to let them leave, as they had the right to decide, but tried to get their Native American converts and friends to stay despite the consequences for the village.

The Pennsylvania Provincial Minutes demonstrated that the colonial government was aware of struggles among the Delaware, the Shawnee, and the Iroquois. While the English surely recognized the lack of control the Iroquois had on the Delaware and Shawnee, they also recognized the lack of control they had on their own colonists who were living in the Pennsylvania frontier. This lack of control would further exacerbate the mistrust and violence in the colony and on the frontier. 
The Moravians, even before the removal of the Delaware from Meniolagomekah, lived among these displaced Native Americans. They lived on English land, taken from the Delaware, and interacted with all the local political powers. The Moravians were not faultless in their treatment of the Delaware, having purchased Delaware land from the English to create missions and towns. The Delaware, as they had before, charged that the English had unlawfully gained the land - and the Iroquois, again, ignored their allegations. However, once the Moravians recognized the injustice done to the Delaware, they offered the use of the land back to the Delaware rent free.$^{61}$ Moravians wanted the Delaware on the land. Not only were the Delaware possible converts, they were also useful neighbors and partners. Moravian reliance on their neighbors for food and converts placed the Moravians in a position of dependency, an unusual position for Europeans in the mid-eighteenth century.

The next chapter explores the creation of community in the village of Gnadenhütten. It will look at several themes in community building and follow the Native Americans and Moravians from Meniolagomekah to Gnadenhütten. The Moravians were using three distinct ways to create a community out of disparate groups: through shared experiences, shared culture, and shared goals.

${ }^{61}$ Merritt, At the Crossroads, 98. 


\section{Creating Cohesion}

Chapter One focused on the larger pressures facing the Moravian Indian congregations on the Pennsylvania frontier. The Iroquois wanted the Native Americans to move closer into their sphere of influence. The English wanted the Native Americans removed, giving more land and territory to white settlers. While Native Americans were facing these pressures, the Moravians were trying, successfully, to unite rather than divide these disparate groups. This chapter focuses on the mechanisms of building community and the daily lives of the Moravians and Indians in the villages of Meniolagomekah and Gnadenhütten. Examining the years from 1753 through 1755, before Native Americans attacked and destroyed the village of Gnadenhütten, it uses the remaining diaries from these villages to explore the increased tension between the imperial actors and the Moravians and their Indian converts. This chapter argues that the Moravians were creating community amongst the groups through shared experiences, shared culture, and shared goals. Moravians cataloged their shared, everyday experiences, in the diaries, including the ways that they worked and lived with one another. Internal visits, visits to each other within the boundaries of the village, cultivated their shared culture through discussions between the European Moravians and the Native American converts about religion and concerns. Visits of outside forces, both Native American and European, honed the community's shared goals, in the face of those who sought to divide the community, in the case of the Native Americans, or aimed to reinforce the Moravian culture in the case of the Europeans.

\section{Creating Community}

The Moravians, whether in Meniolagomekah or Gnadenhütten, lived, worked, and worshipped alongside their American Indian followers. Their primary goal was the salvation and 
baptism of the Indian souls. ${ }^{1}$ By focusing on shared experiences of the community members, the Moravians were making personal and spiritual connections with their Indian counterparts, which, they hoped, would lead to their conversion and salvation. The Missionaries recorded the daily activities that united strangers as friends and families in the community diaries of each village. As mentioned in the previous chapter, the communities of Meniolagomekah and Gnadenhütten had different goals. In Meniolagomekah, there were one or two full time missionaries who preached and lived with the Indians in a village in the woods, alongside several itinerant missionaries who frequently visited the village. In Gnadenhütten there were several married Moravian couples, husbands, wives, and children, who allowed pious Indians and their family to live within the village. There was ample movement between the two villages, even prior to the permanent move of the Meniolagomekah Indians to Gnadenhütten.

Everyday Life

Meniolagomekah was a Delaware town built on a foundation of Delaware ideals. The inhabitants maintained their way of life from previous settlements, with roles and jobs based on their gender and skills. The Delaware and the Mohicans were matrilineal groups where men held much of the outward political power (council leaders, Sachem, shaman, etc.) but women were the ones who voted the male leaders into position, held 'possession' of the land, and controlled the family and the home. When Delaware couples married, the husband would join the wife's family longhouse or wigwam. Within the larger nation, there were also smaller groups made up

${ }^{1}$ At the end of each year's community diary the diarist, in many cases Schmick himself, would count the souls that they had saved. At this point they did not name the converts, but rather just counted them. 
of clan members. A child's clan was determined by his or her mother's clan, and the mother's brother (if she had one) was the most important male figure in a child's life. ${ }^{2}$ Given the social power of women in Delaware and Mohican society, it was often women who converted to Christianity and requested that their children also be converted. The Delaware culture was heavily dependent on women and the connections they made.

While Indian traditions were prominent in Meniolagomekah, in Gnadenhütten the social and cultural ideals were a combination of German and Indian. Moravian leaders desired that the Indians residing in the village live communally, pooling their resources and provisions, a customary practice in Moravian communities until 1763. The Indians did not find this a difficult request to accept, as they were already used to a partially communal life. ${ }^{3}$ They continued to live in family units, based on their clan, and larger tribe, affiliation; They hunted, gardened, and labored with people with whom they already had connections. The Moravians, however, wanted to promote what they considered German traits: industriousness and frugality. They, like many Europeans, considered hard, physical work virtuous, and the American Indian way of live was not particularly onerous. ${ }^{4}$ This desire to change cultural traits is shown in the ways that Moravians attempted to teach the Indians how to do daily activities, such as clearing their fields and planting their crops.

${ }^{2}$ Clans were an additional divider in an indigenous tribe. First was the tribe, and then, within the tribe, there were smaller groups, generally each with their own animal totem. Clans existed across tribe or nation. For instance, if a person was a member of the bear clan and they visited another tribe, the other tribe's bear clan would welcome them as family. Even people of different nations considered their clans families, often to the point where marriage between clans was considered incestuous. Merritt, At the Crossroads, 137.

${ }^{3}$ Merritt, 151. Delaware Indians did have economic independence. However, they were apt to share goods and resources within their clans if not fully tribal wide.

${ }^{4}$ Merritt, "Cultural Encounters along a Gender Frontier." 
Food

\section{Clearing the Land}

Before any agricultural activities could take place, farmers in this heavily forested area of Pennsylvania had clear the land. In the 1753 diary from Meniolagomekah there are no entries concerning the clearing of forests to create farmland, probably because the village was a Delaware village that existed before the Moravians arrived in Pennsylvania. In Gnadenhütten, however, there were several diary entries that recorded clearing land to prepare the area for the new village and the "plantations" of the village inhabitants. There are few details about how the land was cleared in the diaries, but they do tell us that Brother Martin Mack went out to the land that was to be cleared with the Indian brethren, in order to instruct them on how best to achieve the goal..$^{5}$ It is important to be attentive to the specific language used to describe these actions in the diaries. Schmick wrote on March 4, 1764 that Brother Martin went to "instruct" the Indian brethren on clearing the land. The assumption that accompanies this word is that the Indians were either deficient in their knowledge of clearing land, or that the Moravians considered the way the Native Americans traditionally cleared the land was unacceptable. ${ }^{6}$ While their methods

${ }^{5}$ MAB, MissInd 1.11.118.1, March 4, 1754.

${ }^{6}$ Wallace, Indians in Pennsylvania. American Indians had methods to clear land that included burning the underbrush in the forests (which created wide, unhindered paths) and felling trees through controlled burns (which created fields surrounded by the forests), but in many cases the American Indian would move the entire village when the earth lost its nutrients. American Indian villages generally had a smaller population than European villages and towns, and the Indians lived on a vast continent where land was readily available and was not commodified in a European sense. Approximately every twenty years the native village would move. Because they relied on wood, hides, bones, and other biodegradable materials as tools in their daily lives, the inhabitants could move quickly and efficiently. They would take apart their longhouses and wigwams, move miles away, and then rebuild their village. Compare this mobility to European society. While Europeans lived in villages, towns, and cities, the village itself was not a moveable feature. People in Europe were mobile, but the cities and villages were stationary. This was in large part due to the heavy and expensive materials that villagers used for tools and buildings. Also, since the Middle Ages, village, towns, and cities had legal charters granting them permission from the local lord to stay on the 
of clearing the land differed, and the Europeans wanted to force the Indians into European-style farming, they shared the goal of clearing the land.

\section{Planting}

Once they cleared the land for planting, the Indians throughout America relied on the agricultural efforts of women; farming and agriculture was traditionally women's work in most groups. American Indian women planted and harvested the three sisters: corn, beans, and squash, which they planted together because of the efficiency of grouping crops in this way. ${ }^{7}$ This codependent planting allowed the Indian women to go about other chores, as they did not have to go out into their fields to continuously weed between tidy rows of corn. When the Europeans saw the method of farming the Indians used, which was particularly well-suited for peoples without domesticated animals, they failed to see the logic behind it. ${ }^{8}$ The Indian system needed little maintenance and produced food in enough quantity that the community was self-sufficient.

land. Villagers were unable to uproot their homes, churches, and permanent structures, so they created a way to remain where they were while maintaining the integrity of the soil. Since the early Middle Ages, Europeans have been rotating their fields and crops. In fact, it was largely due to warmer weather and the change to a three-field rotation in the eleventh century that caused the European population to dramatically increase. The Native Americans did not have to concern themselves with stones, concrete, iron, or permanent structures. Nor did they have legal allegiances to feudal lords whom they owed their safety and had pledged their work. They also did not have to invent ways to better use the land for agriculture. Land was plentiful; they could easily move the village to a new place. Instead they were independent, mobile, and remarkably well suited for their land.

${ }^{7}$ Arthur Caswell Parker, Iroquois Uses of Maize and Other Food Plants (Albany, University of the state of New York, 1910), http://archive.org/details/iroquoisusesofma00parkrich. First, planted early, was the corn. According to research, Iroquois, and probably their southern neighbors, began planting corn early in the season before the last frost. They would mound up the dirt around the plants, and when the corn stalk was approximately six inches tall they would cover it again with dirt to keep the roots and stalk warm. In this way the corn stalk grew stronger by having to force its way out of the earth a second time. A strong stalk was important because beans were planted in the hill around the stalk, and the beans used the corn stalk as a trellis, growing up the stalk. Beans also added nitrogen into the earth, thus giving nutrients back to the soil. Then squash was planted, also in the hill around the stalk. Squash, whether gourds or summer squash, have large, spreading leaves that quickly covered the undergrowth between the stalks. These leaves kept in moisture and kept out sunlight, creating an environment that helped the wanted plants and deterred weeds.

\footnotetext{
${ }^{8}$ Cronon, 43-44.
} 
Despite the importance of the three sisters and the history of agriculture in Indian communities, the Moravians, and other Europeans, tried to teach their converts the proper way to plant and harvest: the European way. This was evident when, on May 6, 1754, Schmick recorded that "Brothers Martin and Schmick went with the brothers from Meniolagomekah and our conference...to instruct the former on their plantations." 9 Once again, the Moravian brothers went to "instruct" their Native American neighbors, in this case, specifically, the men from Meniolagomekah who had recently relocated to Gnadenhütten. This implies that these Delaware, who lived removed from constant Moravian supervision, were seen as not capable of planting crops correctly. This entry also showed the imposing gender roles that the Moravians expected the Indians to follow. The Moravians took the "brothers" to the plantations to learn the proper way to farm, not the women, who were the traditional agricultural workers for the Delaware and Mohicans.

The Meniolagomekah diary from 1753 did not mention any instruction on Native American planting. Instead, Büninger recorded that the Indians began planting in May and in October recorded that the corn was ready to harvest. There were no diary entries about the brethren working in their fields, indicating that either Büninger did not find it necessary to record, or that the Delaware were following a traditional Native American agricultural systemwhere they did not have to spend hours in their fields weeding the rows of mono crops. ${ }^{10}$

${ }^{9}$ MAB, MissInd 1.11.118.1, May 6, 1754. "Den Vormitt. ging Br. Martin u. Schmick mit den Brrn von Meniowol u. unsern Conferenz Brrn über den Leche, um ersterne ihre plantagen daselbst anzuweisen. Sie waren froh u. sehr dankbar davor weil sie das Land in solchen Zustand kriegen, dass sie gleich pflanzen können.”

${ }^{10} \mathrm{MAB}$, MissInd 1.18.122.3. 
Unlike the diaries from 1753 in Meniolagomekah, during the summer months of 1754 the diary recorded that Moravian Indian brethren (brothers and sisters) in Gnadenhütten worked diligently in their fields. ${ }^{11}$ This was a departure of the traditional American Indian system where the women were the primary agricultural worker while the men went on hunts, possibly ranging hundreds of miles, to supplement the primary staples of corn, beans, squash, nuts, and berries. ${ }^{12}$ Schmick consistently recorded that the Indian "brethren" went to work in the fields, whether planting or harvesting, indicating that men and women were both working in the fields. This detail showed that Native American agriculture and gender roles were changing, yet, they were not completely European, since the women were also continuing to work in the fields. ${ }^{13}$ The Moravians did not force conformity, as the Indians adapted and now shared the work, with the women taking control in the fields when the men went on hunts.

\section{Harvest}

In 1753 there was only one diary entry devoted to harvesting; Büninger recorded that the Delaware were "happy that their corn was ready to harvest" on October $1,1753 .{ }^{14}$ It seems that October would be late in the season to harvest, yet Native Americans did not use and eat corn the way modern Americans do. Rather, they let the corn dry on the stalk until later in the season and then used the corn for its meal, creating flour which they used for bread and thickening powder.

${ }^{11}$ MAB, MissInd 1.11.118.1, MissInd 1.11.118.2.

${ }^{12}$ Cronon, 44. Cronon notes that women had so much social and cultural capital because they were the primary providers in the community.

13 The European ideal of men working the fields and women not was not necessarily a reality. Often only wealthier farmers could afford to not have their female family members working in the fields. Poor women always worked the fields, but although it was normal, it was not the cultural ideal.

${ }^{14}$ MAB, MissInd 1.18.122.3, October 1, 1753. "Die Geschw. waren fleissig an ihrem Korn einsamlen." 
However, in 1754, the Moravians at Gnadenhütten began harvesting their corn in June, early for a Native American corn harvest. Despite the instruction of Brother Martin and the other Moravian brothers, weeds overran the plantations. On June 12, 1754, the diary entry read: "began to harvest some corn, the weeds were overflowing." 15 This was not a normal harvesting, and several more days of harvest were recorded through the summer and fall, with the last harvest entry dated October 5, 1754. Four months of harvesting was unusual, and one would assume that earlier in the summer they only harvested the small ears of corn to save them from the weeds, leaving whatever corn was not at risk of being choked out by weeds to mature on the stalk.

The difficult harvest in 1754 illustrated the divergent tactics of agriculture between the two cultures. Despite the instruction of the Europeans and the diligent work in the fields by the Native American men and women, weeds overran their rows of corn to the point emergency harvests were necessary to save what crop they could. In that same year, in a sharp contrast, the Delaware in Meniolagomekah planted in May and harvested in October, with no recorded labor in their fields.

\section{Hunts}

Hunting was a necessary and religiously infused activity in Native American cultures. Traditionally, hunting was less essential for their diets, given the success of their farming techniques, but it was necessary for the many tools and materials they received from the

\footnotetext{
${ }^{15}$ MAB, MissInd 1.11.118.1, June 12, 1754. "Den Tag über fingen dir Geschw. an ihr Welschkorn zu behacken, weil es seil viel Unkraut hatte..."
} 
animal. ${ }^{16}$ Since the sixteenth century there was an expansion of hunting for commodity, specifically furs, that came with the Europeans and the entrance of the American continent into the trade market. Market driven hunting nearly wiped out many species and replaced the subsistence style hunting that nations and tribes traditionally practiced. Prior experience led indigenous hunters to treat their prey as infinite. Once they were hunting animals not as a food source, but as a source for goods and other commodities, over-hunting wiped species out of their natural habitat. Usually, the hunters in this region went out for food, to hunt deer and bear. The Moravian Indians did not seem to actively participate in the fur trade, usually only selling furs to get provisions for the winter.

The diaries recorded that Indian men, and teenage boys, would leave on hunts ranging from small hunts lasting a few hours, to larger expeditions spanning weeks. Sometimes they returned to the village empty handed, sometimes they returned with several deer and bear, and sometimes they would return with other Indians who would visit for a few days before leaving to return to their own village. The Moravian brothers do not seem to have gone hunting with the Indians, except one record where the Synod from Bethlehem went to visit Gnadenhütten and the Moravian men joined the Indian men on a bear hunt: “Ten Indian brothers, without the largest

${ }^{16}$ Unlike Europeans, the American Indians did not traditionally have domesticated animals to use for food and other animal products. To get meat and animal products they had to hunt. To get fat, which they used for both cooking and oiling their hair and skin, they had to hunt. To get material for clothing, they had to hunt. Indians used hides to make leather. They used animal brains to tan and condition the leather. They used sinew for thread. And they used bones of animals as tools. For example, they used the shoulder blades of deer attached to long sticks as hoes to mound the earth in farming. 
boys, left for a bear hunt, to show the Synod guests the process.... At 10 Brother Augustus returned with 2 bears." 17

\section{Starvation}

With hunts being supplementary and agriculture being cyclical, starvation was a constant threat to mid-eighteenth-century frontier life. However, as Cronon noted, starvation was not common among Indians. ${ }^{18}$ There are few records in the community diaries about starvation and general lack of food. Yet, by carefully reading the diary entries we can see that food, and the lack of it, led to uncertainty in the village of Meniolagomekah. In May 1753 Brother Büninger left to carry a message to Bethlehem, expecting to be gone until June 4, 1753. On his way to Bethlehem, however, he was caught in a thunderstorm and became ill. When he returned to Meniolagomekah on July $19^{\text {th }}$, he returned to a shell of a village; most of the village population was gone. At some point within the weeks while Büninger was gone, the Delaware decided to leave. ${ }^{19}$ In the evening of June 27,1753 , much of the village returned. While it is impossible to determine exactly why large numbers of the villagers left or where they went, it is probable that they left to go to larger villages where there was more food. According to the diaries dated

${ }^{17}$ MAB, MissInd 1.11.118.2, August 5, 1754. "Früh gingen 10 Ind. Brr. ohne die grosste Knaben, auf die Bären=Jagd, um die Synodal=Gäste zu tractire...Um 10 uhr brachte Br. Augustus 2. Baren.” The diaries did not record what the hunting process was. They may have used bows and arrows, they may have used muskets and powder, or they may have created elaborate traps to corral their prey into a small area where they were easy targets. Iroquois hunting technique was to track bear to their dens and kill them while hibernating. The Delaware and Mohicans probably had a similar hunting technique. This was the most efficient and straightforward way to kill a large, dangerous animal.

${ }^{18}$ Cronon, 41. Native Americans were more accustomed to going days without food. It is possible that the better provisioned Europeans had grown used to the daily meals, so that when faced with a day without they were more apt to feel the pains of hunger than their American Indian congregants who traditionally had an unregulated process.

${ }^{19}$ MAB, MissInd 1.18.122.3, May 27-July 19, 1753. 
before Büninger's trip, a few of the men went out on a hunt, but the rest of the village remained. Three days prior to Büninger leaving the village there is an entry (May 24, 1753) about the village needing emergency provisions. Büninger sent Agnes, a Christian Indian woman, to Gnadenthal to get the necessary provisions while another Christian Indian, Nathanael, dug for roots. ${ }^{20}$ There is no specificity as to what provisions they needed, but given the mention of Nathanael hunting for roots, it seems likely the village needed food. The last record of planting in Meniolagomekah was May 10, 1753. The Delaware did not begin harvesting their corn, the main staple of Native American diets, until October 1. To make it until harvest, it is probable that many left to stay with Indian relatives and friends for food.

This incident showed the continued connection and support of outside Indian villages. Wherever the group went, villagers welcomed them and fed them for weeks, indicating that their ties to non-Christian Indians remained strong. When Büninger questioned them about the disappearance, he notes in the diaries that they withheld the details about where they stayed. It is possible that they thought Büninger would disapprove of their decision. It is also important to note in these entries the implied connection that the Meniolagomekah Indians had with Büninger. They did not leave the village until after Büninger left for Bethlehem. It is probable that the Indians assumed he would challenge their decision to go to other villages where there was no connection to Moravians, but it is also possible that they felt a sincere friendship for him and did not want to upset him.

${ }^{20}$ MAB, MissInd 1.18.122.3, May 24, 1753. It is interesting here that Büninger sent Agnes, the woman, to Gnadenthal for provisions, while Nathanael went to gather roots. Women traditionally did the gathering, but in this instance Agnes was sent to get supplies. 
The Moravians were well known as missionaries that lived within the community of their converts. While we have looked at how the Moravians supervised and worked with their Native American neighbors, we will now explore several aspects of their personal lives that Moravians and Native Americans shared. First, we will look at births within the two communities, then we will look at the importance and instances of marriage in Meniolagomekah and Gnadenhütten. Next, we will look at the role and scope of sickness in the villages. Sickness may lead to death, and prior to death many of the sick begged for baptism. Finally, this section will look at death in the community, and the number of converts who died in these years. These shared experiences further connected the community and helped build cohesion.

\section{Birth}

Unsurprisingly, the villages were excited by the birth of a new child. The diaries recorded the births of the children in their communities. Usually within a day of a baby's birth, the parents requested that someone baptize their child. Generally, Moravians did not baptize babies. Ideally the sinner would have come to Jesus and request baptism after listening to the word of God. Babies were unable to make that decision itself, yet the Moravians allowed baptism of Native American babies, and Native American parents often pressured the Moravians to baptize their newborn children. ${ }^{21}$ In 1754 the Moravians recorded five Indian births. Schmick did not give any information as to the difficulty of labor, etc., that the women went through. The diary entries

${ }^{21}$ Merritt, At the Crossroads, 101 n. 14. Merritt wrote of the interaction between German and Indian women, even noting that the act of labor and childbirth helped create strong bonds between the two groups of women. 
were succinct: "Sister Anna, Andreas the Delaware's wife, gave birth to a son;"22 "During the night, Sister Verona, Jonathan's wife, gave birth to a daughter."23 Schmick did not write about the connections between Indian and German women during labor, an interaction that could create close connections. ${ }^{24}$

There was little record in the diaries of the actual pregnancy or labor of women. For instance, beginning in February 1754 there were several diary entries about Esther; Schmick wrote that Esther, Augustus' wife, came from Meniolagomekah because of her sickness. ${ }^{25}$ Other women went to visit her in her sickness. By the end of February, Schmick recorded that she was worse, and they expected her to go home, the Moravian term for dying: "Last night it seemed that Esther would go home. Her friends and brethren were with her so she wouldn't be troubled or unhappy; she told her friends that she was blessed and went with pleasure in her heart to the savior." 26 Ester did not die that night, however. On March 5th she gave birth to a daughter, and Schmick finally recorded that she had been seven months pregnant. After the delivery she begged Brother Martin to baptize the baby girl, whom he christened Esther, but after the baptism, both mother and child died. ${ }^{27}$ It was not until the day that Esther gave birth to her daughter that

\footnotetext{
${ }^{22}$ MAB, MissInd 1.11.118.2, August 31, 1754. "Fruh kam die Schw. Anna des Andreas Del. Frau mit eine Söhnlein glücklich nieder."

${ }^{23}$ MAB, MissInd 1.11.118.2 December 23, 1754. "Erweichene Nacht kam die Schw. Verona des Jonathans frau mit einem Töchtergen glücklich nieder."

${ }^{24}$ Merritt, At the Crossroads, 143-44.

${ }^{25}$ MAB, MissInd 1.11.118.1, February 8, 1754.

${ }^{26}$ MAB, MissInd 1.11.118.1, February 24, 1754. "Diese Nacht schien es, als welte dir Esther hiemgehen. Ihre freunden, waren bei ihr nebst etl. Von unsern Geschwistern; sie sagte zu ihren freunden, dass sie notwegen nicht betübt seÿn dürften, sie wäre selig u. ginge gerne u. mit einem freundigen herzen zum Hld."

${ }^{27}$ MAB, MissInd 1.11.118.1, March 5, 1754.
} 
there was any indication of pregnancy, rather than the diary's suggestion of a regular, albeit long, illness.

\section{Marriage}

Marriage, and the physical act of sex, were mystical experiences for Moravians that brought each person closer to God. Yet, this importance to Moravians did not require a strong nuclear family. Instead Moravians created choirs, one choir per social group. ${ }^{28}$ The diaries showed little evidence of choir life in the village, however. The Indians in these smaller towns were living in extended family networks, the traditional norm for them, but it is probable that when Moravian Indians visited Bethlehem or Nazareth, larger communal based towns, that they slept and worshiped within choirs. There are diary entries that state when choirs met, but the evidence seems to show, especially in Gnadenhütten, that the married Europeans lived together in nuclear families. In contrast, Indians lived separated by ethnicity, Mohican and Delaware, and lived in extended family huts.

\footnotetext{
${ }^{28}$ In Bethlehem there were several choirs, the Married Men and Women, the Single Brothers and Sisters, the Widows and Widowers, and the Boys and Girls. Each of these choirs spent most of their time within the choir. They slept in dormitory like conditions, ate together in a hall, and worshiped all as a choir. [Gillian Lindt Gollin, "Family Surrogates in Colonial America: The Moravian Experiment," Journal of Marriage and Family 31, no. 4 (1969), 652.] Each choir had daily chores and an elder of their own sex supervised them. Since married coupled did not live together in the town, times were set aside each week for them to meet in private to worship as a couple.(Gollin, 654) This eventually gave way to couples living together in their homes, while the young, single, and widowed Moravians remained in choirs until the 1770s. (Gollin, 657) The choirs were useful in supporting the collective community. If the families were separated by nuclear connections, they, ostensibly, could put the wellbeing of the family above that of the community as a whole. Instead, the Moravians created a social system of family surrogates, that raised and monitored their own sex while placing the physical act of sex between a husband and a wife on mystical footing. The emphasis on sexual completion to get closer to God has led some scholars to believe that extra-marital and homosexual sex also found their way into the Moravian church. [Paul Peucker, $A$ Time of Sifting: Mystical Marriage and the Crisis of Moravian Piety in the Eighteenth Century (Penn State Press, 2015).] The period of Christian Renatus has essentially been erased from the archival history of the Moravians.
} 
There were two recorded weddings in 1754. One was between Zacharias and Phoebe; these Moravian Indians must have already been a couple, since after their wedding the Moravians gave them a hut to share with their children. ${ }^{29}$ It is probable that Zacharias and Phoebe wanted a place to stay within the village and given the fact they were already baptized (as evidenced by their Christian names), and were already a couple, they understood that the Moravians expected them to be married and asked for the ceremony to formalize their relationship. Schmick only gave the other marriage that year a few words in the diary, writing on December 31, 1754: “Married: Daniel, the widow Judith's son, and Elsy from Westenhuck, both Mohican" ${ }^{30}$ It is possible that the new year ceremonies were more pressing than a wedding, since the rest of the entry described the number of congregants and residents.

\section{Sickness}

Sickness was rampant in eighteenth-century Pennsylvania, especially among Native American populations. In the diaries of the villages there were several records of at least one person in the village being ill. In fact, there were instances in Meniolagomekah where the sick Delaware would go to Gnadenhütten: "Maria, Samuel's wife, went with their child to Gnadenhütten. They will stay there for a while with their friends because of her sickness." ${ }^{11}$ It is probable that the Delaware from Meniolagomekah went to Gnadenhütten to take advantage of the medical knowledge of the European Moravians. Europeans were already inoculated against many of the diseases that ravaged the Native American population. While the colonists and their

\footnotetext{
${ }^{29}$ MAB, MissInd 1.11.118.1, February 4, 1754.

${ }^{30}$ MAB, MissInd 1.11.118.2, December 31, 1754. "Getraut sind Daniel, der Wittwe Judith Sohn, mit der Elsy von Westenhuck, beide Mahicander."

${ }^{31}$ MAB, MissInd 1.18.122.3, May 20, 1753. "Die Maria, Samuels frau, ging mit ihrem Kind nach Gnadenhütten, sie will sich eine weile dort auf halten bey ihren freünden weil sie kränklich ist."
} 
Native American neighbors were unaware of the specifics of the diseases, they recognized that the treatments of the Europeans saved more lives than those of the Native Americans. This was probably because the Europeans themselves were able to care for the Indian sick. If the Native Americans attempted to care for the sick, they were also likely to contract the sickness. In many cases this may have caused the American Indians to reject traditional medicine and prayer and turn to European medicine and prayer-after all, the Europeans did not die at the same rate as the Indians.

There were at least three people from Meniolagomekah nursed by Moravians in Gnadenhütten in 1753. Maria, Samuel's wife, was there for months, as she left Meniolagomekah in May and did not return until August 3. On August 19, 1754 Thamar went with her daughter to Gnadenhütten to visit her sick children, which showed that the Moravians were willing to help heal Native Americans regardless of their religious affiliation. In this instance, it was only the grandmother, Thamar, who Schmick named, and presumably the only one baptized. Yet, she and her daughter were on their way to Gnadenhütten to visit her ill children who the Moravians cared for.

\section{Baptism}

Baptism of Native Americans was the primary goal of Moravians. In 1753 there were at least two baptisms in Meniolagomekah, one for the children (unnumbered) of Josua and Agnes, and one for a young boy who was ill: "Nathanial went to Gnadenhütten, because his sister's eight-year-old son is very sick." ${ }^{32}$ Initially, Martin was apprehensive about baptizing the boy,

\footnotetext{
${ }^{32}$ MAB, MissInd 1.18.122.3, May 10, 1753. "Nathanael ging als Botte nach Gnadenhütten, weil seiner Schw. Sohn von etwa $8 \mathrm{Jahr}$ alt sehr Krank ist. Die Mutter des Kindes ist nach ungetauft, sie hat aber dach verlange
} 
regardless of his illness, as the diaries record: "Brother Martin wrote to me that he can come to no resolution on baptizing the boy, because the mother herself is not baptized." ${ }^{33}$ Martin, after reading to the boy and his mother, and praying on the subject, agreed to the baptism, and gave the boy the name Christian. ${ }^{34}$ This instance showed that despite the pressure of the mother and a baptized relative, the Moravian clergy did not rush into baptizing young children. In the diaries, there were several instances of Moravians baptizing babies despite the Moravian ideal. This usually happened if the Moravians felt the baby was too ill to survive into young adulthood; the diaries noted that the parents of the baptized baby felt comfort once the Moravians baptized the child and gave it a Christian name. In the case of the sick woman, Esther, the baptism of the premature baby girl happened immediately following her birth. Esther begged Brother Martin to baptize the baby so that she would go to God when she died. However, Esther, herself, was baptized into the Moravian community already, while Nathanael's sister was not. This could indicate that the Moravians gave greater weight to the desires of the mother over other relatives, since Nathanael's' request was initially denied. It could also indicate that the Moravians gave more weight to the desires of baptized biological parents. ${ }^{35}$

\section{Death}

das Ihr Sohn möchte Getaufft werden, sie sagte mein Sohn wird villeicht sterben, und er ist noch nicht Getaufft. Das Kind selber hat verlangt das er möchte Getaufft werden. Ich schrieb destwegen an Br. Martin, und gab Ihm Nachricht davon."

${ }^{33} \mathrm{MAB}$, MissInd 1.18.122.3, May 11, 1753. "Nathanael kam zu rück von Gnadenh. Br. Martin Schrieb mir das er mit der Tauffe des Knaben, noch zu keiner Resolustion kommen können, weil die Mutter selbst noch Ungetaufft ist."

${ }^{34}$ MAB, MissInd 1.18.112.3, May 18, 1753.

${ }^{35}$ There was no indication in the diary that the lot was used to make either of these decisions. 
In 1753 there were only two recorded deaths connected to Meniolagomekah. Christian, the young boy who Brother Martin baptized after Nathanael's petition, died on May 24th and was buried the next day. Hannah, Brother Augustus' daughter who lived in Gnadenhütten, died on July 30. The brothers from Gnadenhütten sent the message to Meniolagomekah and wanted to know when Augustus would be home from the hunt, as Hannah needed to be buried soon.

Brother Josua went to Gnadenhütten to attend the burial since Augustus would miss it; Augustus returned from the hunt on August 2nd but was too late to attend the burial. ${ }^{36}$ The quick turnaround between death and burial probably had to do with the time of the year. The diaries do not mention the weather (unless it is a particularly heavy rain, strong thunderstorm, snowstorm, or flooding) or the heat, but given that both Christian and Hannah passed in the warm months, it is probable that the Moravians wanted to bury them as soon as possible to avoid unnecessary decomposition of the corpses.

1754 saw more deaths in Gnadenhütten. This could be due to the role of the village as a place where Moravians cared for ill people. Obviously if there is more sickness in a village, there will be more deaths associated with that village. There were eleven recorded deaths in Gnadenhütten in 1754 , but the diary entry for December 31 counted fifteen total deaths to the congregation. $^{37}$

\section{Economy}

${ }^{36}$ MAB, MissInd 1.18.122.3, July 30, 1753-August 2, 1753.

${ }^{37}$ MAB, MissInd 1.11.118.2, December 31, 1754. 
The American Indians and the Moravians were skilled workers who were willing to do physical subsistence work within the village in addition to selling their goods outside of the village to contribute to communal provisions and money. Some of the goods that the diaries mention being produced and sold are: barrels, tar, baskets, brooms, and deer skins. Both men and women participated in this economy and used the skills they possessed to help their community financially.

\section{Skills}

The Native American Christians in the villages were willing to work using their skills, and to learn new skills to help the greater community. The diary from 1753 had nine entries specifically recording economic activities, not including hunting. In these entries Delaware Indians went and sold their goods to settlers for village provisions. Women in Meniolagomekah wove baskets and made brooms. ${ }^{38}$ Generally, it was women who left the village to sell baskets, five of the nine entries concerned with selling goods specifically mentioned women selling baskets. The diary entries described women traveling to Gnadenhütten, Bethlehem, Cranberry, and Mensing to sell their baskets. ${ }^{39}$ There were more records of Indian women leaving in 1753 to sell their goods and get provisions than there were in 1754. It is probable that the lack of total Moravian supervision in Meniolagomekah meant that women had more spatial freedom than the women in Gnadenhütten. The 1754 diary had three entries that specifically mentioned baskets, and one that mentioned selling baskets as well as brooms. On December 9, 1754 the Indian

38 They would leave the village to go into the forests to gather vines and bark for baskets. They also would gather cattails (sawgrass) that they wove into sleeping mats. The grass stalks are hollow, which create a cushion to protect the bodies from the cold floors.

${ }^{39}$ MAB, MissInd 1.18.122.3 
women of Gnadenhütten asked men who were leaving on a hunt to gather wood for baskets while they were in the forest. ${ }^{40}$ Then on December 17 an unnamed woman (who were probably not baptized) came to the village with wood for baskets. ${ }^{41}$

In 1754 Gnadenhütten, there were other types of selling and economy taking place. While Meniolagomekah seemed to focus on women making baskets and selling them to settlers, the Gnadenhütten diary had entries that recorded men leaving the village to work and make money. Of the seventeen entries that specifically mentioned economy in Gnadenhütten, eleven entries mentioned men as the ones who were working or producing. There were several entries devoted to Brothers Martin and Lesly and tar-making. ${ }^{42} 1754$ also included the only entries where men went to colonial towns to sell buckskins and furs. One entry from 1753 reported that men returned from a successful beaver hunt, but it did not go on to record that the men went on to sell the pelts; in 1754, however, there were several records of men traveling with their skins to earn money.

There were many villagers among the European Moravians who had specialized knowledge. Schmick was a well-renowned musician and teacher, Martin had medical and agricultural knowledge, Lesly knew how to make tar, and Brother John Peter was a cooper. Someone in the village was a smith, since not only did they make a smithy, but in April 1754

${ }^{40}$ MAB, MissInd 1.11.118.2, December 9, 1754.

${ }^{41}$ MAB, MissInd 1.11.118.2, December 17, 1754.

${ }^{42}$ MAB, MissInd 1.11.118.2, December 9, 1754. Once they completed making the tar, in a hut outside of the village, the brothers went to Bethlehem to sell their product. Tar production was a lengthy process. Production of the tar began in September and completed in November. Brother Lesly left to sell the tar in December. 
Shawnee who were visiting with their leader for political reasons asked if they could remain and see the blacksmith. ${ }^{43}$

The economy of these villages, especially that of Gnadenhütten, reflected the communal goals of the Moravians. Until 1763 the Moravians participated in a communal economy; most of the entries that focus on economy and money the result was to help the entire community. Women made baskets to sell to settlers to purchase provisions for the community. Men were able to make canoes, sell hides, or participate in a labor economy, and the money they received went back to the community at large. These actions showed that the European Moravians were working with the Native Americans in the frontier area to survive. They shared not only the daily activities of life in the village, but also shared in their life's triumphs and defeats, and in their wealth and poverty. Everyone was working toward a communal goal.

\section{Internal Visits}

Moravians and Native Americans created community through shared life experiences. They maintained those connections and implemented cultural teaching through daily interactions, and there were almost daily records of besuchen, or visits, within the community. Throughout 1753 and 1754 inter and intra-village visitations occurred regularly. To analyze these visits and their themes, I have divided them into internal and external visits. Internal visits were those among the members of the village: daily meetings with neighbors, not including the regular services and meetings of choirs and Conferences. These visits served to reinforce the

\footnotetext{
${ }^{43}$ MAB, MissInd 1.11.118.1, April 14, 1754.
} 
shared culture of the Moravians. The Europeans did not force their dogma on their Indian converts, but they expected them to live within certain moral guidelines.

The visitations were meetings in which the visitors would express their religious doubts, their social concerns, and reinforce their belief in the work of Jesus and the Holy Spirit in their lives. According to the diaries, it was usually the Indian brethren, or brown brethren as the Germans referred to them, visiting the white brethren. They would meet in the white brethren's house and talk about religion and the state of the Indian's soul. These visits maintained the spiritual and social well-being of the community, as well reinforced the importance of Moravian ideals.

\section{Religious Doubts}

It is evident from the diaries that the European Moravians were using daily visits as religious therapy. Not only were they listening to the worries of their converts, but they were also offering them advice and trying to bring them closer to God. Most of the diary entries, whether from Meniolagomekah or Gnadenhütten, do not tell of the specific troubles of the person who was having religious doubt, instead, recording few specific details and referring to visits more generally. This could be due to the shared nature of the diaries. If the Moravians recorded religious doubts that they were unable to placate, this may have given the missions in Meniolagomekah and Gnadenhütten, and Pennsylvania at large, a bad reputation.

Internal meetings based on individual faith queries occurred in both villages. Brother Büninger wrote about men and women that came to him to discuss their faith and the happiness they found in the Savior. While there is little doubt that these meetings were important parts of the communal interaction, many of the entries that recorded the doubts and problems of the parishioners seemed formulaic. The Indian heart was either right or poor. On October 8, 1753 Büninger wrote about interactions with Brother Nathanael and Josua: "he assured me that his 
heart would not turn from the holy or the brother's way... I also had a heartfelt talk with Brother

Josua, his heart is right." 44 Days later he met with "poor" Ruth who "complained to me about her misery with many tears." 45 These interactions did not give the specific words and worries that the person had; instead, they give the emotions and the supposed outlook of the Native American convert.

The imagery of the heart was recurrent in the diaries. On January 14, 1754 Schmick recorded: "Brother Augustus had a heartfelt talk with Brother Martin. He wanted the savior to work on a new heart with him, because he sometimes had shameful thoughts..."46 In 1754, in Gnadenhütten, there were seventy-two entries that contained the word heart. Many of them were like the above quote-men and women going to the Moravian leaders and praying for a new or better heart, or a heart that would be full of Jesus. In another instance a Native American named John Jacob went to Brother Martin “and told him about his restless heart, which he himself created, because he was not obedient to the savior and the brothers, but he was still certain of his good intentions." ${ }^{47}$ John Jacob felt conflicted, or Schmick portrayed him as conflicted, between what he felt and what he thought he should feel. The diary did not explain his issues in any

${ }^{44} \mathrm{MAB}$, MissInd 1.18.122.3, October 8, 1753. "Ich hate eine lange abnde mit Br. Nathanael, weil er in die Jerseys auf die Jagd will und das Abendmahl darüber versäumen thut. Er versicherte mich das er mit seinem herzen nicht von Hld. Nach den Brr. weg wolle...Ich hate auch eine herzl. Bande mit Br. Josua, er ist recht selig in seinem herze." thräumen."

${ }^{45}$ MAB, MissInd 1.18.122.3, October 13, 1753. "Die Armen Ruth klagte mir ihr Elend mit villen

${ }^{46}$ MAB, MissInd 1.11.118.1, January 14, 1754. "Mit dem Br. Augustus hielt Br. Martin noch eine herzl. Bande, u. er war offenherzig, gesunde auf, was er manchmal gedacht hätte er schämte sich aber von herzen..."

${ }^{47}$ MAB, MissInd 1.11.118.1, February 2, 1754. "John Jacob besuchte den Br. Martin und sagte ihn wem der Unruhe seines herzens, die er sich selben gemacht hätten, weil er dem Hld. u. denen Brüdern nicht wäre gehorsam gewesen die doch gewiss auf sein Wohlseÿn bedacht wären.“ 
further detail. Given that this entry is from February 1754, it is probable that John Jacob was facing the pressure of deciding whether to follow the desire of the Iroquois and leave the village.

Even though the village did not rely on the choir system for social organization. the Moravians usually divided visits between the sexes. In Meniolagomekah, however, Büninger was an unmarried brother, and this distinction meant that both men and women were approaching him to confess their doubts and worries. This gendered division was one of the reasons why married missionaries were able to be effective, as they were able to split the work between the husband and wife based on the sex of the communicant. It is evident, however, that the European brethren, both brothers and sisters, would discuss significant visits among themselves. On February 21, 1754 Schmick wrote that Lea, Christoph's wife, visited Anna (Mack) in the Mack home: "She was frank and testified, through tears, the troubles she had a while ago about her poor condition. But, she feels that the Savior is working in her heart again."48 This entry shows that the male and female missionaries reported to each other about the spiritual well-being of their flock. Even though Lea did not directly speak to Schmick, Anna Mack clearly informed him of Lea's worries and resolution. The European Moravian leaders, regardless of their sex, were working together to assuage the doubts of their converts. The Moravian leaders, both European and Indian, met and worked together to maintain the culture and teachings of the church. They were not always successful in their attempts, but they were working diligently to maintain the community. ${ }^{49}$

${ }^{48}$ MAB, MissInd 1.11.118.1, February 21, 1754. "Sie war offenherzig u. bezeugte mit Thränen ihre Unruhr, die sie eine Zeit hergehabt über ihnen Herzen arbeitet."

${ }^{49}$ Continued unsuccessful attempts led to expulsion form the community-either forced or voluntary. 


\section{Social Concerns}

Among the Moravian leadership, there was worry that the Indians who had converted to Christianity would revert to their traditional culture and beliefs. ${ }^{50}$ There was particular concern that the young Indians, particularly the young men, would turn from the teachings of the Moravians and return to traditions of their tribes and clans. The Moravians were aware of the tensions on the frontier, and they worried that the young, idealistic men would become reactionary against Europeans. They worried especially when young men left for hunting trips and interacted with non-baptized Indians. The diaries made this fear evident in the meetings and conferences that the Moravians in Gnadenhütten held, with either the leaders or their entire congregation. There was less of this written apprehension in the diary from Meniolagomekah, probably since it was not wholly under the purview of the Moravians. Instead, in Meniolagomekah, the Delaware invited the Moravians to the village. There were several instances in Gnadenhütten where Moravian leaders met to discuss the well-being of their flock, and still other instances where the leaders met with the entire congregation to remind them why they chose to remain here. These instances showed the connection and maintenance of the communal bonds the European Moravians and Native Americans created in the village of Gnadenhütten.

While there was little proof of the Moravians combatting actual subversion among the young men in the community, there was one diary entry that mentioned young men specifically. On January 12,1754 , Schmick wrote about young men grinding and shaving their heads "to lead

\footnotetext{
${ }^{50}$ Merritt, At the Crossroads.
} 
and seduce one another to another, but we could not conclude how to help the matter...."51 In this instance there were young men who were continuing the social and cultural traditions of their people, which Schmick referred to as "heathen customs". ${ }^{52}$ Native American peoples decorated and designed themselves based on their tribe and clan association, and by following traditions (probably Mohican) that were Native American, the young men were defying the culture of the Moravians. ${ }^{53}$ Schmick showed this subversion with his choice of the word "seduced". Indian culture seduced the young men, and by shaving and plucking their hair, they were guilty of trying to seduce other young men. It seems that this was not a sexual seduction (although homosexual relationships were permitted with many Native American groups) but a cultural seduction, exactly what the Europeans feared was possible because of the contact with the non-baptized. As Schmick noted, however, the Moravians "could not conclude how to help the matter." ${ }^{54}$ On January 30, 1754 Brother Jacob, a Mohican man, went to talk to the young men in their homes. ${ }^{55}$ There was no record what they discussed or how the young men responded, but it is worth noting that this was the only entry of its kind for the year. Moravian leaders decided to send a Mohican man instead of sending a European to talk to the young men, demonstrating a certain amount of awareness for the Moravians. Instead of chastising the young men, which may

${ }^{51}$ MAB, MissInd 1.11.118.1, January 12, 1754. “...u. wir einer den andere dazu verleite und verführe, konnten aber zu keinem Schluss kommen, wie der Sache kann geholfen werden."

52 MAB, MissInd 1.11.118.1, January 12, 1754. The phrase Schmick used was "heidenische Gewohnheiten".

53 These young men were probably Mohican because in January 1754, when Schmick recorded this entry, the villages had not yet merged. The majority of Native Americans in Gnadenhütten were Mohican.

${ }_{54}$ MAB, MissInd 1.11.118.1, January 12, 1754.

${ }^{55}$ MAB, MissInd 1.11.118.1, January 30, 1754. 
have led to even more rebellious behavior, they had Jacob, a respected man of the young men's own culture, talk to them.

While many of the meetings about social concerns took place between the European and Native American converts, there were instances where the European brethren met and discussed the Native Americans amongst themselves. On February 8, 1754, Schmick wrote, "the white brethren had a conference about Indian things, about the circumstances in Gnadenhütten." ${ }^{56}$ This short record of the meeting does not indicate what they discussed, or what conclusions, if any, they reached. This was before the permanent addition of the Delaware to the village of Gnadenhütten and it is highly probable that the "circumstances" they were discussing was the pressure to leave the village and relocate into areas more closely monitored by the Iroquois. The record gives further evidence to this assumption a few days later. On February 11, 1754, Schmick recorded that the Moravians "had conferences held over the circumstances in Gnadenhütten". ${ }^{57}$ The community was debating its future. Augustus, a Mohican man, "summed up our points and the reasons why brothers should or should not go there [Wyoming]." Brother Petrus exhorted the congregants to "think about why they [the Iroquois] came to Gnadenhütten. ${ }^{158}$ In this instance the Moravian leaders were having community hearings about what they, as a community, should do. The decision to discuss the options facing the group

${ }^{56}$ MAB, MissInd 1.11.118.1, February 8, 1754. „Den Vormittag brachten die weisen Geschwister, die mit der Ind: Sache zu thun haben, mit Conferenz= halten zu, über die Umstande in Gnadenhütten.“

${ }^{57}$ MAB, MissInd 1.11.118.1, February 11, 1754. „Der Vormittag wurde wieder mit Conferenz=halten zugebracht über dir Umstände in Gnadenhütten...Den Nachmittag war eine Conferenz mit dem Augustus in Ausehung das nach Wyomick ziehens u. er fasste unsere Sinn u. in was vor einem Sinn wirs den Brüdern rathen u. auch wieder nicht rathen, dahin zu ziehen. Die Abend-Versammlung hielt Br. Petrus. die Matterien worüber er redte, wurden in der Confernz beschlossen in Absicht auf die Leute, die eine Zeitlang schlecht gestanden...dahero sollte ein jedes sich sinnen, warum es nach Gnadenhütten kommen ist. Es hörte alles mit Attention zu.“

${ }^{58}$ MAB, MissInd 1.11.118.1, February 11, 1754. 
showed the European Moravians' dedication to their Native American converts. Church leadership would decide for the European Moravians, but the village Europeans listened to the Indians and relayed their opinions to the church leadership. Members of the village were not acting unilaterally, instead they were listening to the views and opinions of people within the community. These views were passionate and well-argued, and eventually some of the Moravian Indian converts decided to leave the village in 1754.

\section{The Savior at Work}

The diaries were again vague when describing the specific ways in which the American Indians discussed the role of Jesus in their lives. Yet, based on the diary entries, Schmick recorded several instances where Indian converts told Moravians that they felt the presence of God in some detail. Given the inherent bias of our sources, it is impossible to know whether the Native Americans felt what Schmick wrote, but the diaries indicate that Schmick believed them and took them at their word.

In Meniolagomekah there were fewer entries where congregants said they recognized or felt the Savior in their daily lives. In all there were only fourteen entries from Meniolagomekah that used the abbreviation for Savior, compared to the sixty-five entries in Gnadenhütten that contained the abbreviation, Hld, which stood for heiland. In Meniolagomekah, there were several times where Büninger, the diarist, recorded that the Native Americans asked about the Savior, and Büninger himself supported his congregation by telling outsiders about the connection the Native American Moravians had with the Savior. These entries were as simple as when Josua and Agnes saved an Indian woman who said that she "can no longer live without the Savior in 
her life".${ }^{59}$ This entry reflected the nature of the Indian village, where unknown Indians would come and offer themselves and their hearts to the faith.

In Gnadenhütten, there were more frequent mentions of the Savior. As in Meniolagomekah, many records were generalized, noting that people were praying to the Savior, while other members specifically mentioned the role of the Savior in their lives. The latter held especially true when it came to the sick people in Gnadenhütten. On March 1, 1754 Esther, a sick Indian woman, told her friends that the Savior eased her pain. ${ }^{60}$ On April 6, 1754 a sick man, Brother Jeptha, said he had "a genuine desire for the Savior, and to kiss his wounds." ${ }^{61}$ Jeptha's sickness progressed and on April 9, 1754 Schmick wrote that all the brethren were happily visiting and were cheerful. Yet, amidst that cheer: "Brother Jeptha's heart was heavy, thinking on the wounds of Jesus. He begged his daughter, Lydia, and her man to remain for their entire lives and to live with the Savior, but it will come to nothing. They promised him and that was dear to him." ${ }^{2}$ This entry shows us two salient facts: first, Schmick saw his duty as a devout man as trying to help his family stay connected to the Moravians and Jesus. Whether this was the real motivation of Jeptha or whether his motives were less spiritual is unknown, and without Jeptha's own testimony, impossible to determine. Second, a father was asking his daughter and her husband to remain with him. The pressure to move continued, and many of the Native

${ }^{59}$ MAB, MissInd 1.18.122.3, April 5, 1753. „sie könnte nicht länger ohne den Hld. leben.“

${ }^{60}$ MAB, MissInd 1.11.118.1, March 1, 1754.

${ }^{61}$ MAB, MissInd 1.11.118.1, April 6, 1754. ,hat ein wahres Verlangen bald beyn Hld zu seyn, und seine Wunden zu küssen." This imagery of kissing the wounds of Jesus was not uncommon among Moravians.

${ }^{62}$ MAB, MissInd 1.11.118.1, April 9, 1754. "Br. Jeptha wurde sehr schwach; sein herz aber lebt recht in Jesu Wunden, er redte davon wir wohl u. selig er darinnen ist, und bat seine Tochter die Lydia und ihrern Mann, dass sie doch auch aller Tage darinn bleien, und den Hld lieber krigen, ja sich durch nichts daraus bringe lassen mögten; Sie versprochens ihm auch, u. das wr ihm lieb.“ According to Schmick, Jeptha was baptized on April 24, 1754 , when he was one hundred years old. 
Americans, especially those young and/or connected to unbaptized Indians, felt the pull to leave the village.

After time away from the village, those who returned often reported feeling rejuvenated and feeling closer to the Savior. On April 10, 1754 Schmick recorded that: "In the afternoon some Indian brethren came home with happy hearts, that they had the time to spend with the Savior in their lives." ${ }^{93}$ It is possible that the returning Moravian Indians were sincere in their reports about renewed spiritual awareness, but it is also possible that the Christian Indians were visiting with unbaptized friends and family while they were away from the village and upon returning to the village wanted to ease the worries of the Moravian missionaries. Given that many of them defied the pressure of the Iroquois and the smaller tribes to remain with the Moravians, it seems that conversions were sincere. However, there was likely an awareness, especially after the disappearance of the Delaware villagers in Meniolagomekah the year before, that Moravians were anxious about the spirituality of their Indian converts. By returning to the village with assurances that they felt closer to God, they were assuring the European Moravians that they were not straying from the Christian message.

\section{Vices}

While Moravians were not as strict in their need for cultural assimilation as the English, they did, however, require that baptized members of their community behave in a moral and virtuous manner, even removing people from the community who were unable to meet their

${ }^{63}$ MAB, MissInd 1.11.118.1, April 10, 1754. "Nachmittag kamen einige Ind. Schwestern nach Hause, waren ihren herzen noch vergnügt, und haben die Zeit ihres Aus seyes im Umgang mit dem Hld. gelebt."“ 
expectations. For the Moravians this meant three specific actions: participate in sexual activity only in recognized marriages, do not act in violence, and do not succumb to vices such as drinking, gossiping, and lying.

There were only a few diary entries that dealt specifically with these vices. The punishments for failing to live up to Moravian moral ideals were varied. In some occasions, especially with drinking, the European Moravians reprimanded the offending Native American men (of the entries that record drinking, it was always men who were the imbibers) who then, according to Schmick, felt ashamed of their actions. On January 25, 1754, Schmick wrote that two Native American men from the village, Johann Martin and Salome’s son-in-law (an unbaptized and unnamed man) returned drunk from a hunt: "These two were with one another on the hunt, two miles from here they encountered a company of Indians who were going to Nescopeko, and they had rum that they gave to the men."64 The next day (January 26, 1754) Johann Martin, Salome's son-in-law, and three of the Indians from Nescopeko were drunk in the village, and the Native American brethren went to Brother Martin to ask for counsel. Two days later, Brothers Josua and Anton, two Mohicans, talked with the men from Nescopeko. The men apologized for their behavior and excused themselves from the village. This was a moment where the Moravians used the actions of outside Indians to show the converts the consequences of their actions. The diary entry of January 30, 1754 recorded that Brother Jacob, a Mohican,

\footnotetext{
${ }^{64}$ MAB, MissInd 1.11.118.1, January 25, 1754. „Diese 2 waren mit einander auf der Jagd; 2 Meil von hier begegunten ihnen eine Compagnie Indianer, die nach Nescopeko zugingen, die hatten Rum bei sich, u. gaben ihnen, bis sie besoffen waren." In Pennsylvania it was illegal to sell rum to Indians, yet that does not mean that Indians were not able to acquire alcohol. First of all, the Pennsylvania government even agreed to bypass their own law and grant Indians who were willing to fight for the English a small ration of rum. Secondly, with Indians trading with Europeans it was inevitable that alcohol would be part of the trade.
} 
spoke with men from the congregation who admitted their sins and decided to devote themselves to God and the Moravians: "They could see that the Brothers' hearts were true, and they wanted what was best for their lives and souls." 65

While the community allowed the men who admitted their sins to remain in the village, in 1754 there was a scandal that caused the expulsion of two members. On May 4, 1754 Nathanael and his family, wife and child, from Meniolagomekah came to stay in Gnadenhütten. Nathanael was a Delaware but was involved in the building of the new town of Gnadenhütten. On June 23, 1754 there was one line in the diary that suggested a much larger story: "Nathanael and Salome had a hearing to investigate." 66 Other entries in the diaries show that Salome was an older woman (since she had a grown daughter who had a baby) who was living in Gnadenhütten. There is no mention as to her tribal identity but given that the catalog and maps of Gnadenhütten listed her prior to the move, she was probably Mohican. The next day the committee told Nathanael "that he had given offense to everyone here, and that he could no longer live in Gnadenhütten, and that he should search for another place to stay." ${ }^{\prime 67}$ Nathanael did not take this information well, he wept and was unable to speak to the committee. The next day he and Josua went on a five-day hunt. During the time that Nathanael was on his hunt with Josua, the

\footnotetext{
${ }^{65}$ MAB, MissInd 1.11.118.1, January 26-January 30, 1754. "Sie sehen wol dass der Brüder Herz er treu mit ihnen meinte $u$. ihr bestes von ihren Leib u. Seele suchten."

${ }^{66}$ MAB, MissInd 1.11.118.1, June 23, 1754. "Nathanael u. der Salome gehörigst zu untersuchen."

${ }^{67}$ MAB, MissInd 1.11.118.1, June 24, 1754. „Kündigte ihn an, dass er wegen seines gegebenen Argernisses allhier, nicht länger in Gnadenhütten bleiben könn, sonders sich einen andern Plaz vor die Zeit suchen soll.“
} 
committee confronted Salome: "Brother Bechtel, Künaft, and Goetje took the Indian Salome and announced to her that they thought she was a seducer in Gnadenhütten, over which she cried."68

In this instance the word "seduction" could mean either cultural or sexual seduction.

Given the Moravian strictures on extra-marital affairs, and their response to the event, it is probable that it was sexual seduction. ${ }^{69}$ Village leaders removed both Nathanael and Salome due to their behavior; Salome, unlike Nathanael, left the next day, and left her young son, Johannes, with Brother John Peter who raised him to be a cooper. ${ }^{70}$ Nathanael, upon his return to Gnadenhütten, met with Brother Joseph before he left. He decided to stay close to the village, albeit as an outsider, in a nearby hunting cabin. Nathanael worried that if he were to leave the Moravians he would "become worse than any other savage." ${ }^{71}$ It is important to point out that the word Schmick recorded Nathanael saying was "savage". This word choice showed the changing relationship between the Native Americans and their European neighbors. Indians were savages, and European ways could redeem them. Nathanael was worried that without Moravian oversight he would revert to savagery. It is also worth noting that the Moravians did not call Nathanael out as a seducer. It may be that the unwritten specifics of the scandal implicated that the seduction was on Salome's part, or it may be that seduction was a female crime.

${ }^{68}$ MAB, MissInd 1.11.118.1, June 25, 1754. "Brother Bechtel, Künaft, u. Goetje kriegte die Ind. Salome vor u. kündigeten ihr an, dass sie als wine Verführerin von Gnadnehütten soll, vorüber sie sehr weinte."

${ }^{69}$ Nathanael and Salome both had time where they could have interacted in Meniolagomekah prior to moving to Gnadenhütten. The diaries showed that movement between the villages was frequent. It is possible that they were having an illicit affair in Meniolagomekah that went unnoticed due to the lack of Moravian supervision in the Indian town. It is impossible to determine how long they had been seeing one another, or even what the details of their interactions were. Yet, given the relative freedom in Meniolagomekah compared to the interactions and oversight in Gnadenhütten it is possible that it was long running.

${ }^{70}$ According to Schmick, Salome's son, Johannes, begged to stay in the village.

${ }^{71}$ MAB, MissInd 1.11.118.1, June 29, 1754. "Er könn in diesen seine jezigen Umstände noch ärger als ein anderer Wilder werden." 
These examples of admonishment and exile showed that the Moravians were willing to enforce their community morals. They built community through shared experiences, shared culture, and shared goals. Part of sharing community is also determining rules of the community. The above discussion showed that the Moravians were willing to listen to the arguments and explanations of the accused, accepting the apologies of the men who had gotten drunk with the Indians from Nescopeko, for example. This may have been due to the situation - the foreign Indians were the ones, according to Schmick, who offered the alcohol to the community members, who were then ashamed of their behavior. Yet, the Moravians removed Nathanael and Salome from the community despite the tears and apologies. It is probable that the distinction between the two was one of severity rather than remorse.

\section{External Visits}

Throughout the diaries there were several mentions of specific people who have come to visit the villages from other locations. External visits include visits from high-ranking Moravians from Bethlehem, from American Indians, and from European neighbors who lived outside of the village. These visits often had religious and political import. There was a difference in the types of visits received in Meniolagomekah versus those in Gnadenhütten. Generally, Meniolagomekah, as a Delaware town, received visits from Native Americans at a regular rate. Gnadenhütten, on the other hand, was more likely to see visits from Moravians who lived outside of the missionary town. High-ranking Moravians from Bethlehem often visited Gnadenhütten to ensure that the missionaries were successful, and to maintain a place in Native American society. Unbaptized Indians who visited Gnadenhütten came for one of two reasons: to visit friends and see the Europeans out of curiosity, or to relay a message from a Native American leader. These politically motivated visits forced the villagers come to terms with issues they were having- 
with the expectations of political powers like the Iroquois, and with themselves. If anything, these discussions strengthened the resolve of many in the communities - thus creating shared goals.

Visitors to both villages came for political reasons, as a stop on long travels, and for commonplace emergencies. The political emissaries demonstrate that the neighbors, both Indian and European, were looking to the Moravians for treaties and promises. The travelers who stopped for rest reflect the reputation of the village as a safe place for Native Americans, baptized and unbaptized, to stop and rest on their journey. The neighbor who stopped for a medical emergency showed that he trusted the skills of those in the village, especially Brother Martin and his medical training.

Before examining the sources describing the visitors and motives for visiting the villages, it is important to remind the reader that travel during the mid-eighteenth century in Pennsylvania was not an easy affair; it was not a quick jaunt in the woods between villages, through dappled sunlight, and over bubbling creeks. The mountains and forests in the eastern half of the state, where these villages were, created paths that were windy and narrow. ${ }^{72}$ American Indians were mobile people who walked through the forests and crossed rivers to reach their hunting land, their plantations, and their relatives. In Pennsylvania, the easiest route was the forest path, created in the open forests of Pennsylvania which allowed for easy trail movement. Pennsylvania was heavily forested with nut trees, large, thick trees that created dense canopy. Yet, despite the

\footnotetext{
${ }^{72}$ Merrell, Into the American Woods. Merrell describes the importance of the Pennsylvania forests as an actor in Pennsylvania history.
} 
vastness of the Pennsylvania forests, there was little underbrush. ${ }^{73}$ These forest paths connected Pennsylvania villages in a comparable way that rivers in Europe connected cities.

In Europe most of the large and financially successful cities were situated on waterways. This was not coincidental. It was due in large part to the easily navigable rivers that connected European cities. Unlike the rivers of Europe, many of the Pennsylvanian rivers and creeks have strong currents and rapids, making them difficult to pass. This, combined with the materials used to make canoes in Pennsylvania, made it more difficult than practical for the Indians to use waterways as the primary mode of movement. ${ }^{74}$ The American Indians of Pennsylvania used the combination of creeks, streams, rivers, and trails to move throughout the forests. They used a highway system that included ferries of canoes at points on trails, and provisioned trail huts that with wood for fire and shelter from the elements. Indians created a system of trail markers using trees to signal that the traveler was on the proper path. Finally, they had towns and villages on these paths, to rest. In these villages their clans welcomed them, even if they were from different tribes; they were family, not strangers. Travel in Pennsylvania for indigenous people may have been trying, but the American Indians attempted to make it as easy as it could be.

73 Wallace, 42-46. Eastern woodland Indians, including the Delaware, had a habit of burning the undergrowth to allow for easier movement and easier hunting. The large trees did not burn down, the old leaves and small brush burned, leaving the ash to further nourish the land. The Delaware did not have paths as wide as their Iroquois neighbors, instead their paths were perfect for single file movement, approximately eighteen inches in width, and moved along with the natural topography. The paths were often marked through ingenious ways of pruning and growing trees to make distinctive markers. Given the lack of written language, the indigenous people of the Eastern woodlands had to create markers that would be recognizable to the traveler. Native American mobility in Pennsylvania revolved around forest paths, and Meniolagomekah and Gnadenhütten were built on them.

74 Wallace, 46. Iroquois made canoes out of birch bark and sewed them together to create light, waterproof boats. The type of birch that the Iroquois used is not indigenous to Pennsylvania, and the bark that the Delaware used (elm, oak, or hickory) was not as sturdy as the canoe birch of the Iroquois and would not stand up to the rapids of Pennsylvanian rivers. Instead the Delaware generally used dugout canoes; they were heavy, but virtually indestructible in the water. Because of their weight, however, they were not easily transported between waterways, and were left as ferries between banks where they were often needed. 
This section will focus briefly on general travelers, who recognized that the villages of Meniolagomekah and Gnadenhütten were Christian Indian communities. The diaries record different iterations of the type of traveler. Several diary entries from Meniolagomekah recorded that foreign Indians returned from the hunt with the men, often staying a single night and then leaving for their village in the morning. There were also men and women who came to the villages to visit their friends and relatives, most frequently Moravians from Bethlehem, or the Indians from Meniolagomekah prior to their move to Gnadenhütten. Native Americans from farther east also occasionally stopped in the villages on their travels west. There was one entry that recorded that a group stopped at Gnadenhütten because they had heard from other travelers that there was an Indian village there, further proving that outsiders recognized the village as a community. ${ }^{75}$

\section{Moravian Visitors}

There were many Moravians from Bethlehem who visited Gnadenhütten, and fewer who travelled to Meniolagomekah. These were men who had specific skills who travelled to help the village when they expanded their land on the other side of the Mahoni Creek, or high-ranking members of the church. The Moravians, and Germans in general, were well known for their skilled craftsmanship. During the period of the merger of the two villages, many skilled workers went up the Lehigh to help in the building and creation of a new city. While the new village was not by any means a city by European standards, the diary referred to it as a city, rather than a village. These workers were primarily carpenters, bricklayers, and stonemasons.

${ }^{75}$ MAB, MissInd 1.11.118.2, August 25, 1754. 
The new Gnadenhütten was much bigger than the original village. While there is no map of the new village, the diary recorded the erection of several buildings, with a focus on the communal house. In the autumn of 1754 there was a flood, and the diary recorded the destruction of many buildings. Due to the record of this destruction, we know there was in the village a mill, a smithy, several barns for horses, fences around family gardens, a kitchen, and a school, as well as the communal house, and personal homes for the families.

High-ranking Moravian visitors were men and women who came to the village to interact with the Native American converts, and to ensure that the missionaries were upholding the ideals of the church. In April 1754 the Moravian Synod went to Gnadenhütten to observe the mission town, which indicated that they felt Gnadenhütten was a good representation of a mission town. The Synod arrived on August 5, 1754, after the merger of the two villages, and stayed until August 12,1754 . While they were in Gnadenhütten they had daily meetings and shared news from Moravian missions outside of North America. ${ }^{76}$

Visits helped create and maintain cohesion, shared culture, and goals. The skilled workers from Bethlehem were showing their village counterparts—-whether European or Native American - that they supported them. Their work on the new village showed that they valued the work that the missionaries were doing, and that they welcomed the Native American converts into their larger community. The arrival of high-ranking leaders, and especially the Synod, indicated that the Church considered the village inhabitants important. The members of Gnadenhütten, whether European or Native American, were aware of their place in the larger

\footnotetext{
${ }^{76}$ MAB, MissInd 1.11.118.2, August 5-12, 1754.
} 
Moravian world, even though they lived in the frontier woodlands of Pennsylvania. They had connections with Greenland, Bernice, and St. Thomas because of their faith, and their overall goals.

Neighbors

The Moravians in the mission villages did not have extensive interaction with their nonMoravian, European neighbors. In fact, during the diaries from 1753 and 1754 there were only two entries, one per year, of interactions with neighbors other than Indians. In 1753 Büninger recorded that three neighbors came to him while he was in Bethlehem and spoke with him about the good work that was happening at the village. On June 21, 1753, during the period that Büninger was away from Meniolagomekah, and when the Delaware left their homes, he recorded a short talk he had with three neighbors in Bethlehem: "Three of our neighbors came to me, they were amazed by our Indian brethren, because they were so altered since they lived there and now they preached the gospel... They said it must be hard for me to live alone among the Indians." 77 While this entry reported an interaction with neighbors, it is almost impossible to be certain about the details of the interaction. First, there is no way to know if these neighbors are Büninger's neighbors in Bethlehem, neighbors of Meniolagomekah, or even English neighbors of the city of Bethlehem. Second, there is no specificity when praising the Native American converts to indicate whether they were referring to the actual Delaware in or from Meniolagomekah, or generalizing to include all Native Americans. Third, these neighbors did

${ }^{77}$ MAB, MissInd 1.18.122.3, June 21, 1753. "Es kamen 3 von unseren Nachbarn zu mir, sie verwundern sich sehr über unsern Ind gescw. weil sie sich so viel geändert haben, seit bar bey Ihnen wohnen, und ihnen das Evangelium Pradigen...und sagte ich hätte es darf hart so gantz alleine bey Ind zu wohnen.“ 
not seem to understand how the small village missionaries worked, noting that it must be hard to "live alone among the Indians", while the diaries show that there were other Moravians who were also frequently living with Büninger, including Schmick. Fourth, even in Bethlehem, Europeans had a negative bias against Native Americans. They were praising Büninger for the Native Americans' behavior-behavior unlike what they expected from Indians.

The second interaction with a European neighbor happened in Gnadenhütten. In 1754, Thomas Bier, who lived four miles from Gnadenhütten, asked Martin to go to his home, begging him to take pity and help his sick wife. Martin said that he "would only take care of emergencies with his people where he lived" and initially refused the request. Bier persisted and "said that he had tried and could find nobody else; he implored him to return, he has nine children and is a poor man." ${ }^{78}$ However, Martin eventually relented, going with Bier and performed some bloodletting on his wife, who improved after the service. This diary entry showed how devoted the Moravians in the village were to their community - to the point where they placed the well-being of their community members above the well-being of outsiders, even European outsiders. While Brother Martin acquiesced and went to Bier's house, the frustration in Schmick's diary entry is recognizable. Schmick wrote that, "afterward, Brother Martin returned home. We have sickness of our own and many things to do."79 This addition to the entry recorded Schmick's annoyance that Martin was pulled from the community to care for an outsider on the same day the sick

${ }^{78}$ MAB, MissInd 1.11.118.1, March 5, 1754. „Br. Martin suchte ihn bedenkten, dass es nicht seinen Sache wäre, sich damit abzugeben, er hätte es nur in Nothfall beÿ seinen leuten, wo er eben wohnte; es wären ja leute, deren ihre Sache es wäre, die dergl. Sachen verrichten thäten. Er stigte, er hatte sich schon Mühe gegeben, konnte aber niemands finden; er bat flehentl. Wemdete auf vor, er hätte 9 Kinder, u. er wäre ein armene Mann.“

${ }^{79}$ MAB, MissInd 1.11.118.1, March 5, 1754. „Darauf ging Br. Martin wieder nach Hause. Wir krigten wieder einige Kranken dabeÿ manches zu thun gibst..." 
women, Esther, gave birth to her premature baby girl and they both died. The community was in pain and an outsider came in and demanded the attentions of one of the higher-ranking leaders. Brother Martin did his work, but Schmick, and possibly the rest of the Gnadenhütten community, was irritated by the interruption of their lives.

\section{Moving}

As discussed in the previous chapter, in 1754 the Moravians moved the village of Gnadenhütten from on the banks of the Lehigh River to a spot across the river at the Mahoni Creek. The area of the village was larger than the previous one, and the Moravian Brethren initially allotted land to their Mohican brethren in the plans. The original village of Gnadenhütten was 197 acres while the new village covered an expansive 1,382 acres. ${ }^{80}$ After Peters evicted the Delaware from the village of Meniolagomekah, Delaware leaders and individuals came to the Moravian elders and requested land and homes at the new village on the Mahoni Creek. The villages had been united, but the Moravians wanted the different tribes, the Mohican and the Delaware, to unite together as a Christian community as well.

There was long standing tribal animosity between the Mohicans and Delaware, as Merritt focuses on. Yet, Eastern Woodland tribes had smaller kinship circles, clans, that extended past their tribal family. Thus, there were probably Mohican and Delaware kin who, despite any tribal animosity, continued to interact and engage with each other. This is evident in the diaries of Meniolagomekah and Gnadenhütten, where in the diaries from 1753 and 1754 we see repeatedly

\footnotetext{
${ }^{80}$ Merritt, At the Crossroads, 132.
} 
Delaware Christians visiting their Mohican friends and neighbors, and vice versa. Faith and proximity connected these two villages, even if tribal affiliation did not.

A sketch of the early village (Figure 3) of Gnadenhütten, undated, showed the central position of the communal house and the orderly placement of the other houses in the village. This map showed thirty structures, including the Gemeinhaus, or communal house, in the center of the village. A later map of the village from early 1753 (Figure 4) showed more homes, indicating that their community had grown.

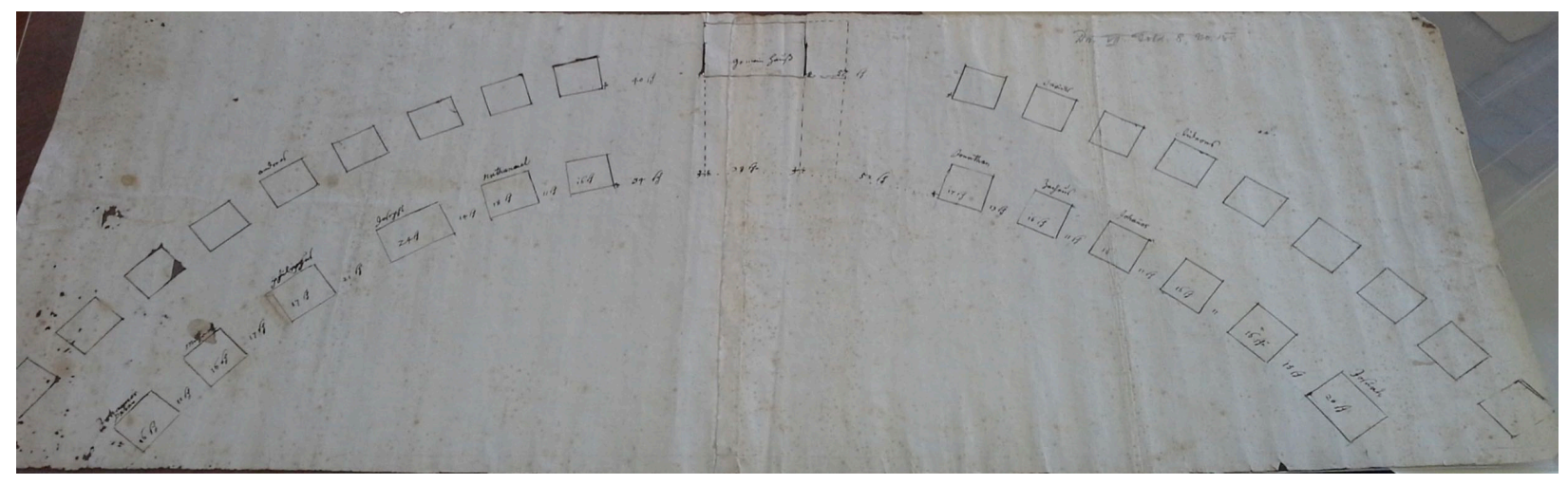

Figure 3: Early Village of Gnadenhütten 


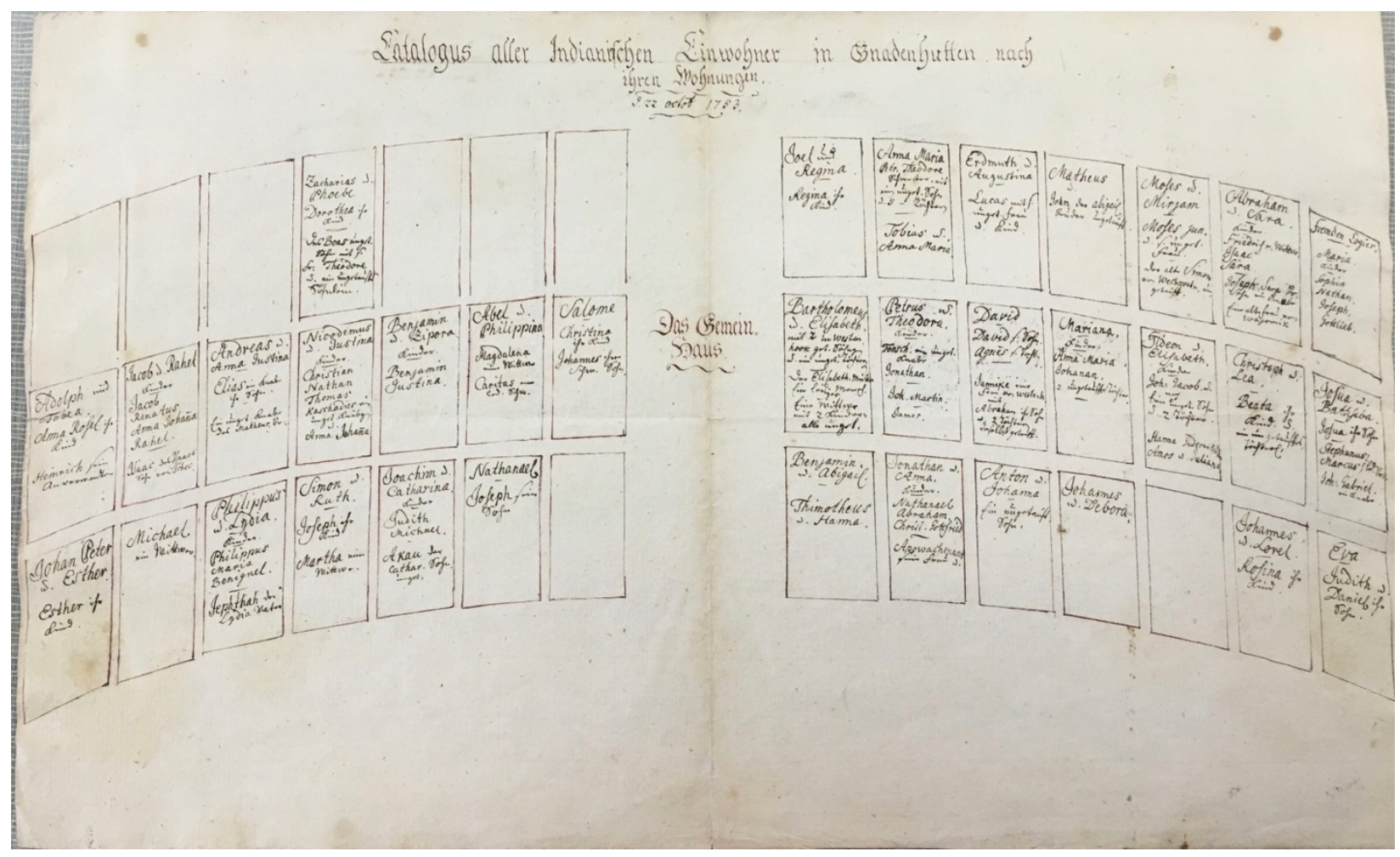

Figure 4: Map of Gnadenhütten, 1753

On May 19, 1753 Büninger counted 59 total people living in Meniolagomekah in May. ${ }^{81}$ A map (Figure 5) made in 1753 of Meniolagomekah showed the layout of the village. It is obvious that it was a smaller scale than Gnadenhütten. In the map there are eleven buildings and sixty-six residents named, not counting the white brothers. The map, however, is only dated with the year so the discrepancy in the number of villagers could be due to births, death, or relocation.

${ }^{81}$ MAB, MissInd 1.18.122.3, May 19, 1753. 


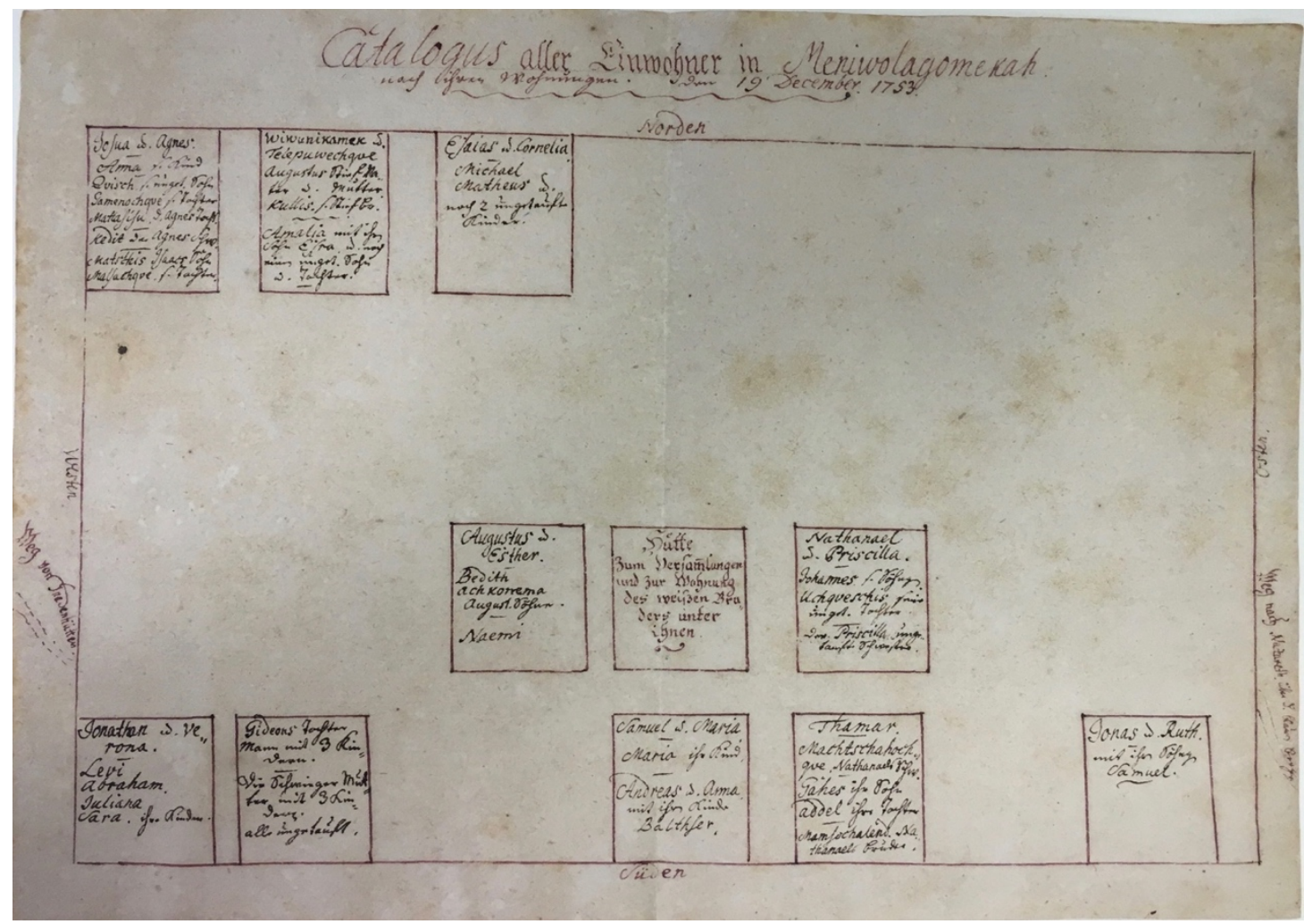

Figure 5: Map of Meniolagomekah, 1753

In April 1754 Schmick counted fifty-four brethren in Gnadenhütten. ${ }^{82}$ This was before some of the Indians of the village succumbed to the pressure of the Iroquois and the English to remove themselves to Wyoming or Shamokin. The map in Figure 3 showed thirty European style single-family houses along with the communal house, while the map in Figure 4 shows forty-two houses. Many of the Native Americans lived in huts, possibly wigwams, and maybe due to the

${ }^{82}$ MAB, MissInd 1.11.118.1, April 11, 1754. 
temporary nature of the structures, they did not warrant a place on the map. The village was not large, but enough land surrounded it for the villagers to use for farming.

On March 11, 1754, the European Moravian leaders crossed the Lehigh to look over the land they had purchased and determine where to put the new 'Indian City'. They then returned to conference with the entire community about moving the village. The next day Schmick wrote: "In the afternoon we went together to the Lehigh and struck the place for our new city." 83 The Moravians were expanding their land and their goals. By March 20, 1754 outside Indians were beginning to petition the European Moravians for plots of land and places within the new village. The indigenous villagers worked hard to clear and prepare the land for occupation, making canoes and rafts. Due to unusually high waters, they were able to use the creek and river to get to Bethlehem to retrieve stones and tools for building. By April 27, 1754, Moravians allotted land in the new city to the Delaware from Meniolagomekah. On June 11 Schmick wrote: "The white brethren went over the Lehigh, to lay the cornerstone of the Communal House." 84 There was a ceremony and several prayers said to prepare the new city. The next day work began on the school house, and Brother Rösler began instructing the boys. By July 29, 1754 Schmick’s new house was ready across the Lehigh in the new village. He, his wife, Johanna, and their daughter, Anna Johanna, went to live in the new town. By this point most of the Native American inhabitants had already moved to the new village. The European Moravians moved over one at a time as they finished their stone homes.

${ }^{83}$ MAB, MissInd 1.11.118.1, March 12, 1754. "Den Nachmittag gingen wir mit einander über die Lecha, u. stekten de Plaz zur neuen Stadt aus.“

${ }^{84}$ MAB, MissInd 1.11.118.1, June 11, 1754. "Gingen die weissen Geschw. über die Lecha, weil der Grundstein zum Gemein-haus sollte geleget werden." 
The preparation and building of this new city took several months. The European Moravians proved to the Native Americans that they were willing to put the time and effort into a new place that would be able to grow with them. This, once again, showed the importance of community. By building a new village, the European Moravians showed that they not only were willing to live, work, and die with the Native American converts, but they were also willing to work toward a committed future together.

\section{Conclusion}

The Moravians, by sharing their lives and experiences with their Native American neighbors were creating multi-cultural and multi-ethnic communities in Meniolagomekah and Gnadenhütten. They did this by sharing their daily lives, their successes and their failures, their language, their beliefs, and their loves and sorrows. They created a newer, larger village as a promise for a stronger future that would grow with new converts. Yet, this new village would not expand or grow as the Moravians hoped. The Native Americans who lived with the Moravians were in a position where outside forces were pressuring them to abandon their Moravian friends and kin. Some of the Moravian Indians decided to leave the village of Gnadenhütten, while many others decided to stay.

Part of community building is the recognition, internally and externally, of being a community. The Moravian community of Gnadenhütten recognized their connection, clearly evident in the amount of thought put into discussing the pressure of the Iroquois to move. Had there been little to no community cohesion, the decision to leave the village would have been an easy choice to make. Externally, both Europeans and Native Americans recognized them as a community. 
The next chapter will explore the decision of the Moravian Indians who chose to leave the village of Gnadenhütten and the merger of the two villages, Meniolagomekah and Gnadenhütten, into the larger village of Gnadenhütten. It will also examine the individual leaders who tried to pressure the Moravians and their American Indian converts. These leaders had personal and political reasons for the pressure they were placing on the groups. Then the chapter will discuss the attack on Gnadenhütten — what exactly happened (as far as we know) and the repercussions of the attack. 


\section{The Attack on Gnadenhütten}

While the Moravians were busy building a multi-ethnic, multi-cultural, Christian

community, the violence in Pennsylvania was increasing. In 1755, Indians attacked the village of Gnadenhütten, and killed nearly a dozen German Moravians. Chapter Three argues that the Moravians in Gnadenhütten had little desire to become involved in the political maneuvering on the frontier, and their hesitation in responding to Iroquois demands led to the attack on their village. I argue that the attack on the village of Gnadenhütten was the direct result of the community's refusal to become involved in political affairs. The Iroquois, and those who styled themselves as allies while seeking to control the Iroquois, considered the village a threat. As noted previously, the Moravian Indians were under direct pressure from the Iroquois and indirect pressure from the English to remove themselves from the Pennsylvania frontier, and move closer to Iroquois power.

The Iroquois Confederacy pressured the Moravians and their Indian neighbors to move to the Wyoming Valley, north of the villages and under Iroquois influence, before the attack in 1755. Numerous proxies of the Iroquois visited the Moravians in Gnadenhütten and tried to determine whether the Moravians and their Native American congregants were going to listen to the Iroquois and move north. The village Indians, the neighboring Indians, and the European Moravians all had to make the decision as to whether they would remain in the areas where they 
were living. They did not make these decisions lightly; they separated families and friends.

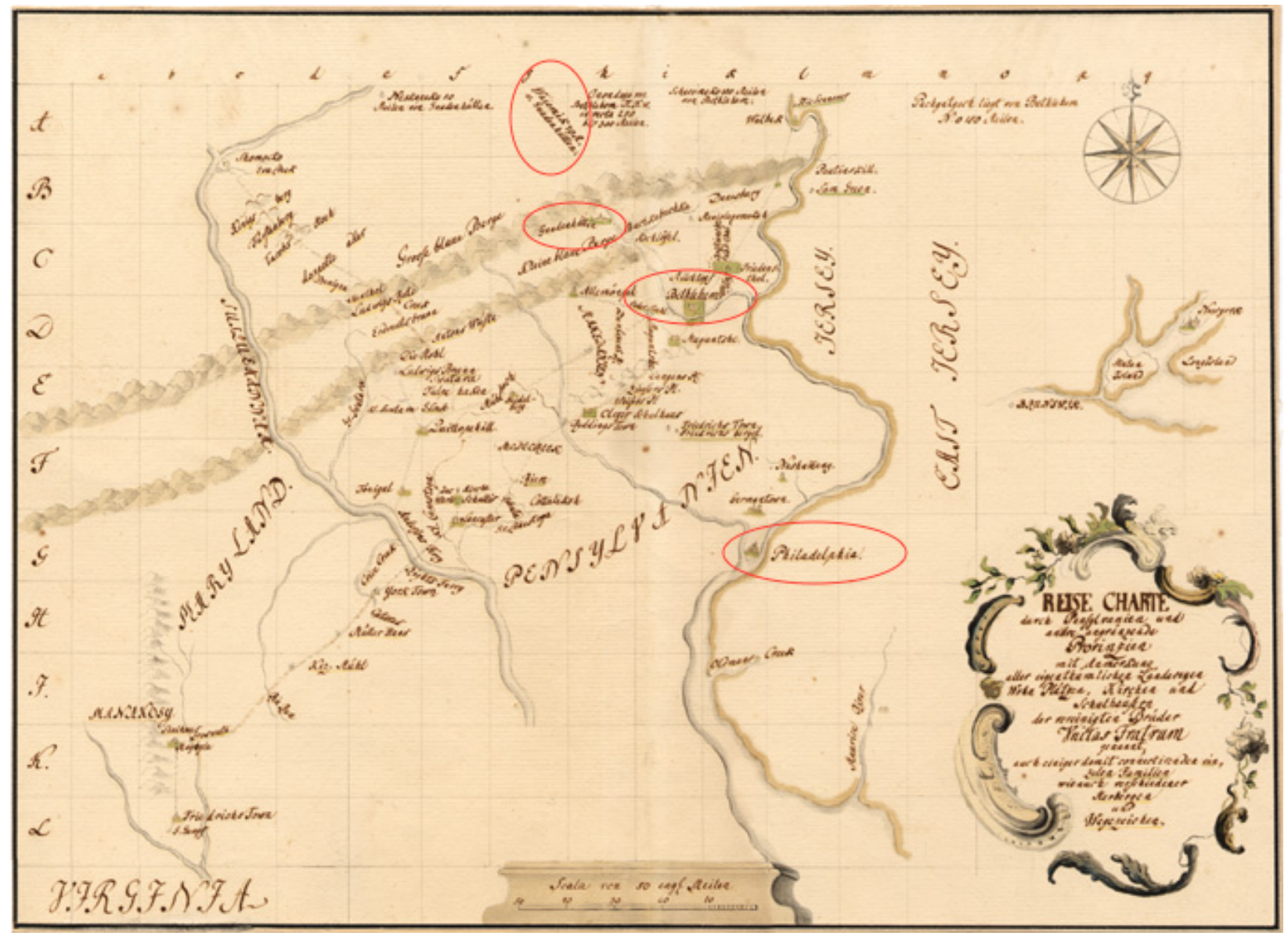

Figure 6: 1750-1755 Pennsylvania Travel Chart

The map in Figure 6 shows the position of the village of Gnadenhütten, between the two mountain ranges, the town of Bethlehem, south and on the Lehigh River, and the city of Philadelphia. It also shows the relative direction of the village of Wyoming, 79 miles north of Gnadenhütten. ${ }^{85}$ This map may show the location of these cities and villages, but it does not

\footnotetext{
${ }^{85}$ MAB, DP f.037.7.
} 
convey the general uncertainty of the eastern settlers, whether Moravian, English, or Indian, which permeated the area. ${ }^{86}$

The Native Americans from Gnadenhütten had several options: move to Wyoming, move to live with extended family, remain with the Moravians, or, perhaps, even leave the area entirely, moving further west. Indian leaders promised places in the village to those who chose to resettle in Wyoming, under the supervision of the Iroquois proxies. Many of the Indians who left for the Susquehanna wept for fear that they would forget the words of Jesus, or that they would not be able to participate in the services of the brethren. By 1755 displaced people filled these Indian villages on the Susquehanna, and the Moravian converts feared they would lose faith.

From 1753 to 1755 , diaries and letters from Moravian leaders in Meniolagomekah and Gnadenhütten continued to record "circumstances" surrounding the Moravian Indians. This chapter will draw on the communal diaries of 1753 and 1754 as well as letters to Bethlehem from Gnadenhütten leaders from 1755. These letters to the leadership in Bethlehem not only focus on the daily actions of the missionaries, but also describe the interactions of the Moravians and their American Indian neighbors. Schmick wrote most of the letters to the Moravian leader in Bethlehem, Bishop Spangenberg. The letters, like the communal diaries, reported on the local activities of the village, but unlike the diaries, they focused primarily on notable events.

My research of these letters showed that groups who were working to determine what the Moravians, both European and Native American, planned to do had surrounded the village of Gnadenhütten. There was no communal diary for 1755 , but several letters to Bethlehem gave

\footnotetext{
${ }^{86}$ Merritt, At the Crossroads, 176-77.
} 
critical information on the daily activities of the community, and by examining these letters, we get a glimpse of the interactions from that year. Unfortunately, the available letters from 1755 did not include the responses that the leaders in Bethlehem sent to Gnadenhütten, likely due to the destruction of the village and any correspondence that existed there.

This chapter will begin by examining the reasons why people within the village of Gnadenhütten chose to either stay or leave the village amidst growing pressure. It continues with a description of the primary Native American political leaders with whom the Moravians had contact. Next, it will focus on the attack itself: when was the village attacked, who was killed, what records remain? Lastly, this chapter will look at the factions exposed in the aftermath of the attack, and the impact on the village and the villagers. It is probable that the communal diaries from 1755 are unavailable due to this attack, and thus the chapter ends there, after the Moravians abandoned the attacked village of Gnadenhütten, later to become Fort Allen.

Gnadenhütten and its villagers, while occupying contested frontier land, were caught between the English and the French, friendly and enemy American Indians. The inhabitants of the village, both European and Indian, risked their lives by removing themselves from the security of the larger towns and cities; yet, for years the villagers remained safe. The rising violence in the frontier, the lack of control the English had over their colonists, and the lack of control the Iroquois exerted on smaller Indian groups that lived in their territory's periphery, was combination of factors which inevitably led directly to the destruction of the Moravian village of Gnadenhütten.

\section{Decisions to Move}

Iroquois, the English, and, less directly, the French and French allies continued to pressure the Moravian village throughout 1754. There were several Native American political 
leaders who visited the village, trying to determine what the Moravians were going to do, and trying to convince Native Americans in the villages to relocate regardless of the European Moravians' decision, which was dependent on communication from leaders in Bethlehem. This section will explore the reasons the villagers decided to stay or leave Gnadenhütten. While some villagers may have chosen to leave because of the political pressure, others chose to remain. According to the diary, there was a large migration of eighty-five people from the village in April 1754. The Moravians referred to this as the diaspora. Not all of them went to the same place, and not all of them left for the same reasons. Diarists recorded some of the reasons, as in the case of Abraham, a Mohican leader in Gnadenhütten, because he addressed the entire congregation. Others' reasons have been lost, never expressed, or never recorded. This section will work chronologically, telling the story of people who were trying to decide whether they would remain with the European Moravians or follow the directive of the Iroquois.

In January of 1754 , prior to the merger of the two villages, Jonathan, a Mohican leader in Gnadenhütten, left for a hunt. His wife, Anna, cried and confided in Esther (probably Johann Peter's wife) that she was afraid to leave the village. Schmick wrote that Esther relayed the following information to Anna, likely Anna Mack, Brother Martin’s wife. Ester found Anna crying and "asked her why she was crying. Anna answered that she had much to cry about." 87

${ }^{87}$ MAB, MissInd 1.11.118.1, January 9, 1754. „Die Esther fragt sie, warum sie senn weinte; die Anna antworteten: Sie hätten Ursach genug zu weinen, sie dächte viel an ihren Mann von etl.n Tagen, ehe er auf die Jagd wäre gegangen, hätte sie gesagt: Mein lieber Mann, besinne dich doch bald, was du thun wilt, u. mache nicht so lange; Ich will die sagen, was ich thun will, ich gehe nicht mit dir an dir Susqueh: wenn du gehen wlt du kanst; Ich aber $u$. meine Kinder willen bei der Gem bleiben: denn wenn ich bedenke, was dHld an uns u. an uns Kindern gethan hat, so kann ich mich uns mögl. Dazu resolvieren, von der Gemeine zu ziehen, ich würde mir ein schweres Gerichte zuziehen. Darauf sagte Jonathan: liebe frau, habe nach ein wenig Geduld mit mir, u. wenn ich wirde con der Jagd zu hausekommen, denn will ich dir eine Antwort sagen; Denn sagte die Anna: daruber denke u. weinte ich, u. warte mit verlangen auf meinen Mann, zu was er sich wird resolvirt haben, ach wir ofte habe ich an ihn gedacht, 
Anna was worried that Jonathan wanted to leave the village, while she wished to remain. She thought to tell him, "I will not go with you to the Susquehanna, but my children and I will stay with the Brethren." 88 Jonathan, however, was using the hunt to come to a decision, "Dear wife, have a little patience with me, and wait for me to come back from the hunt, then you will have my answer." 89 Anna was crying out of her apprehension of her husband's decision; she was worried about the future of her family.

This entry showed the amount of thought and emotion contained in the decision to leave or to stay. If we take the diary entry at face value, we have a family divided in its decision. Jonathan decided to go on a hunt and think about the options that they had; Anna remained in the village and feared that Jonathan would decide to leave. This could either tear apart the family, if Anna and their three children decided to stay, or tear apart their faith community, if they all made the choice to leave. Jonathan returned home from his hunt that night, leaving again a few days later, on the 19th, to visit his parents. The diary did not name the destination, but the diaries did not mention him again for over a week. On February 2, 1754, Jonathan and Anna "had a sincere discussion with the Macks about the children's education..."90 There was no mention as to the reason for the meeting, nor did the diary make any reference to a decision. However, if they were meeting with Moravian leaders regarding the education of their children it meant one of two things: either they were staying in the village and wanted to know how the Moravians

besonders in der Christnacht $=u$. Neu=Jahres Woche, $u$. habe ihm von herzen gewünscht, wenn er doch auch etwas fühlen mögte von der Gnade u. Seligkeit, die und dHld hat fühlen lassen.“

${ }^{88}$ MAB, MissInd 1.11.118.1, January 9, 1754

${ }^{89}$ MAB, MissInd 1.11.118.1, January 9, 1754

${ }^{90}$ MAB, MissInd 1.11.118.1, February 2, 1754. „eine herzl. Unteredung in Ausehung der Kinder Erziehung.... 
were going to be educating their children, or they were leaving the village and wanted advice on how to maintain the Christian and European education their children had already received from the Moravians.

The decision Jonathan and Anna made, while not explicitly recorded, was to stay in Gnadenhütten with their Moravian Christian brothers and sisters. This was the outcome Anna had hoped for, and the diary showed that they both remained active in the village even after the merger. They had a daughter in September who they baptized Christine. Unfortunately, this daughter only lived for nineteen days before passing, perhaps due to an extended illness. Christine was born on September 23, 1754. On September 27, 1754 Brother Martin met with Jonathan to speak about his circumstances. The diary does not specify what those circumstances were, but given that on October 12, Jonathan and Anna's daughter died, one can infer that the community recognized her sickness and was preparing Jonathan and Anna for heartbreak. Even after the death of their infant daughter, they remained active in the community, which showed the strong connection they had with the other members. ${ }^{91}$

While Jonathan and Anna decided to remain in Gnadenhütten, others decided to leave.

On March 2, 1754, Abraham, a Mohican leader in Gnadenhütten, spoke with Brother Martin and suggested he was more willing to go to Wyoming than to stay in Gnadenhütten. On March 11, 1754, Abraham "demanded an opportunity to explain himself to the elders in regard to his circumstances. ${ }^{.92}$ At this meeting he reminded the elders of the promises made to the Nanticokes and Shawnee, and, subsequently, to the Iroquois Nation. He wanted to uphold a treaty that was

${ }^{91}$ MAB, MissInd 1.11.118.2, October 12, 1754.

${ }_{92}$ MAB, MissInd 1.11.118.1, March 11, 1754. "eine Gelegenheit zu haben sich in Ausehung seiner Umstände gegen die Arbeiter zu erklären...“ 
determined in 1752 and wanted the Moravian Indians to leave with him. During the meeting Schmick wrote that his heart had strayed from the Lord, causing Abraham's current position. Abraham begged the Indian elders to think about his words, and they left to discuss the issue. The next day, Abraham seemed less determined to leave, and said that if he did not leave for Wyoming, he would send Paxnous, the Shawnee leader of Wyoming, a string of wampum; if he decided to move to Wyoming, he would not send any wampum to Paxnous. Abraham felt that the gift of wampum would satisfy Paxnous if he decided not to move. However, the following day, March 13, Abraham resolved to leave for Wyoming and asked the Moravians leaders to allow his wife, Sarah, to remain in the village. "We should keep him dear,", Schmick wrote, "he could not take his wife with a clear conscience because she would rather stay here. He also asked the commons to accept his wife and keep her in their care." ${ }^{93}$

On April 24, 1754 Abraham, and many unnamed Indians who joined him, left the village of Gnadenhütten for Wyoming. In the morning the Moravian leaders had a service, reminding the departing members of "the grace and love and blessing of the Holy and his blood and wounds, often enjoyed here, and the wishes from the Brethren here and in Bethlehem, that they should be visited by their brothers." 94 The Moravians, while disappointed by the movement away from the village, still planned to remain in contact with the Native Americans who had relocated. Schmick recorded that sixty-five souls left, including Abraham's wife his Sarah, decided to leave

${ }^{93}$ MAB, MissInd 1.11.118.1, March 13, 1754. „Wir solten ihn lieb behalten, sein frau könnte er mite gutem Gewissen nicht mit unseren weil sie auch lieber wollte hier bleiben; er bat auch, die Gemeine wilte sich seiner Frau annehem, u. sie in ihrer Pflege behalten."

${ }_{94}^{4}$ MAB, MissInd 1.11.118.1, April 24, 1754. ,...der Gnade u. Liebe und Seligkeit die sie beim Heiland in seinem Blut u. Wunden hier sehr oft genossen, und wünschte ihnen mit den 1. geschw. von Bethlehem, deren herzl. Grüsse er an sie ausrichtete, mit dem Versprochen, dass sie con brüdern sollen besucht werden..." 
for Wyoming rather than remain with the Moravians without him. She cried when she said her farewells to those who remained, and promised not to go back to Indianischer Art, or Indian ways, but would keep the Savior in her heart, and keep him dear. ${ }^{95}$

Even though this large group of Native American converts, including Abraham and Sarah, left for Wyoming, they did maintain contact with the village and Moravians. In May, there was a delegation of Indians who came to visit from Wyoming, bringing greetings from Abraham and Sarah. On June 26, 1754, an Indian delegation went to Wyoming to give their words of loyalty to Abraham, who in turn would give them to the Iroquois as proof of their subordination. ${ }^{96}$ This record showed that Abraham now commanded a position of authority among the Native Americans in Wyoming. On June 30, Brothers Martin, Rösler, David Zeisberger, and Carl Friedrich left to visit Wyoming and Nescopeko. On July 5, Martin returned, and reported on his visit in the next day's entry. He wrote that everyone, whether Mohican, Delaware, or Shawnee, treated the "arrivals" well. It is impossible to determine if by arrivals, Martin meant himself and the others on the visit, or if he meant the men and women who had previously lived in Gnadenhütten. While he was at Wyoming, however, Native Americans asked about Jesus and he answered their questions, while Abraham translated. This willingness to interact with the Moravians, and translate their words to curious Native Americans, showed that Abraham had not cut all previous ties to the village.

${ }^{95}$ MAB, MissInd 1.11.118.1, April 24, 1754. „Die Sarah sage: Ich gehe nicht nach Wajomick auf Indianische Art, sondern ich will beim HLD bleiben, und Ihn lieb behalten, dabey vergoss sie noch viel Thräuen.“ ${ }^{96}$ MAB, MissInd 1.11.118.1, June 26, 1754. 
It is difficult to determine why Abraham and Sarah left the village of Gnadenhütten, and yet maintained religious connections with the Moravians. One likely reason may lie in Abraham and Sarah's family dynamic. On January 15, 1754, Sarah was crying; Anna Mack reported that Sarah was distraught because she had just learned that her son, David, had married a woman from Westenheuk and would no longer be staying and visiting with them after this summer. ${ }^{97} \mathrm{It}$ is possible that David's wife, an unnamed and probably unbaptized woman, did not want to live among Christian Moravians, and preferring to live a traditional life with other Native Americans. There were no further records about where David and his unnamed wife decided to live, until July 10, 1754 when Schmick recorded that, "the Indian David and his wife...came from Wyoming to visit. They brought greetings from their parents, Abraham and Sarah, and other acquaintances, to us." ${ }^{.98}$ This entry, combined with Sarah's reluctance to leave, indicated that for Sarah, at least, her wish to be close to her biological family informed the move. It important to note that that Abraham initially asked the community to keep Sarah, because she did not want to leave the Moravians; Sarah in fact left, but the diaries took time to note her promise to remain true to her Christian faith. Abraham and Sarah visited Gnadenhütten in December, when Sarah went to Moravian leaders and confided that the hearts of the Indians in Wyoming were bad. The Moravians reminded her of the love and torture of Jesus and she opened her heart. ${ }^{99}$

Iroquois pressured the village Indians, but it would be far too simplistic to assume that all the Indians left because of the political situation. There were several reasons why members of the

${ }^{97}$ MAB, MissInd 1.11.118.1, January 15, 1754.

${ }^{98}$ MAB, MissInd 1.11.118.2, July 10, 1754. "Der Indianer David mit sr. Frau...kamen von Wajomick zum besuch her. Erstere brachte vierl Grüsse mit con seinen Eltern Abraham und Sarah und andern bekanten von uns."

${ }^{99}$ MAB, MissInd 1.11.118.2, December 4, 1754. 
village may have chosen to stay, and to leave, including personal connections these individuals made to those inside the village or those outside of it. In Jonathan and Anna's case, the connections in Gnadenhütten kept them in the village; while for Abraham and Sarah, the connections they had outside of the village removed them from it. Abraham's words in March may have swayed several Indians, or outside visitors may also have influenced these decisions. In April, Paxnous, the Shawnee leader of Wyoming, came to visit Gnadenhütten during Holy Week, staying with the Shawnee in the village for the week. After Paxnous and the Shawnee left, several other Native Americans had resolved to leave the village. On April 22, 1754 Schmick wrote that "today it was heard that, among others, a few Indian brethren, who would have otherwise been staying here, had also resolved to move to Wajomick [Wyoming]." ${ }^{100}$ While there was no explicit record of the Shawnee pressuring the Moravian Indians to leave the village, there is evidence that the visit of the Shawnee congregation members was influential.

Although significant, this migration from Gnadenhütten did not fully deplete the community. While a substantial amount of Mohicans left the village in late April 1754, new Delaware members entered the village from Meniolagomekah days later. The Native Americans who chose to leave did not completely remove themselves from the Moravians, and many of them visited often, and the Moravians continued to pray for the well-being of their converts who had moved. However, it was obvious that they were not pleased with the decision of those who left: "on the brothers and sisters and children who are leaving for Wajomick [Wyoming], to thank the Savior, and that the unwise children should be handled well. By decision we wished

\footnotetext{
${ }^{100}$ MAB, MissInd 1.11.118.1, April 22, 1754. "Heute hörte man, dass sich unter andern, noch einige Ind. Geschw., die sonst vorgegeben hier zubleiben, auch resolviert hätten, nach Wajomick zu ziehen.“
} 
upon them the mercy of Jesus." ${ }^{101}$ Moravians were not pleased with the decision of several of their converts to leave the village, and this is reflected in the language used: "unwise," to leave a community of faith, and "children", in that they require supervision (an argument that Nicolas Ludwig Von Zinzendorf made in regard to the faith of the Indians) to maintain their faith.

On December 31, 1754 Schmick recorded that eighty-five Native Americans (both baptized and unbaptized with children) had left the village that year. Seventy went to Wyoming and ten went to Nescopeko. Even after the relocation, at the end of the year Schmick counted one hundred and thirty-seven men and women: forty-eight communicants, one candidate, fifty-two baptized, and thirty-six unbaptized. ${ }^{102}$ Despite the emigration of indigenous villagers, the village of Gnadenhütten had not given up hope, and they continued to interact with the villagers who left and maintained the community with those who remained.

\section{Prelude to the Attack}

This section will explore political visitors to the villages, their backgrounds, and the influence they had on the separate villages, and on the combined village after April of 1754. I will introduce these characters in order of appearance in our narrative, and then place them in context within the larger political landscape. Then, I will revisit the narrative, examining when these people came to the village and how they interacted with the villagers.

${ }^{101}$ MAB, MissInd 1.11.118.1, April 28, 1754. „Auch an die nach Wajomick gegangen Brr. u Schwestern und Kindern vor den Hld zu denken, und sie sieb zu behalten, on sie gleich als die unverständigen Kinder gehandelt haben haben. Zum beschluss wünschte Er ihnen, dass die Gnade Jesu Christi unter ihnen walte,..."

102 MAB, MissInd 1.11.118.2, December 31, 1754. 
In Meniolagomekah in 1753, there were fewer political visitors to Büninger than there were to Schmick and Mack in 1754. In fact, of the records from Meniolagomekah named only one Native American visitor to the village who spoke to the missionaries about God. Other Native Americans came to visit with their friends, but usually only stayed for a night or to meet their friends to go out hunting. ${ }^{103}$ However, one should not infer that the Native Americans who came to the village were not political players. While the diary does not indicate that they were actively pressuring the Native American villagers, the entries do suggest the visiting Indians were seeking information.

Cornelius, Anton's father, an old man from the Susquehanna River Valley, demonstrates this information seeking. Cornelius arrived in Meniolagomekah on Palm Sunday, April 17, 1753, and left the Tuesday after Easter. The diary did not specify where on the Susquehanna Cornelius came from, but it is probable that he came from either Wyoming or Nescopeko. Cornelius sought Büninger out and questioned him about Gnadenhütten: "He had many questions for me from the Sachem (Chief) about bad Indians from Gnadenhütten. I told him they (the rumors) were lies, and thereby we read, our Sachem was the Savior and his death became life."104 This entry suggests that there were rumors of unruly behavior among the Gnadenhütten Native Americans, or that American Indians in the Susquehanna region wanted to indicate that there was bad behavior. Büninger denied the allegations, and used Cornelius' terminology to speak about Jesus, naming him a Sachem. It was possible that the Native American leaders were trying

${ }^{103}$ MAB, MissInd 1.18.122.3.

${ }^{104}$ MAB, MissInd 1.18.122.3, April 23, 1753. „Der alte Cornelius besuchte much auch wieder. Er that mir ell. Fragen von Sace die die bössen Ind. Von Gnadenhütt erzehlen. Ich sagte Ihm das es lügen wären, und wir uns nicht damit ein liessen, unsere Sache wäre der Hld und sein Tod mit lieden bekannt zu machen.“ 
to leverage their own power, or maybe sought to spread distrust among the groups, playing up traditional enmities, as Meniolagomekah was a Delaware town while Gnadenhütten was home to many Mohicans. If the Susquehanna Valley Indians were successful in creating a division by forcing a wedge between the villages, perhaps the Moravian Indians would listen to the Iroquois and move into the valley. Cornelius left on April 24, 1753 and did not return to either Meniolagomekah or Gnadenhütten.

Gnadenhütten, unlike Meniolagomekah, received more named visitors who were overtly political and at least two of these visitors had substantial power in Native American communities: Gideon and Paxnous. These men already had connections to the Moravians, through baptism or kinship, and political connections to the Iroquois. Initially these visits seemed to be fact-finding missions to discover what the Moravians planned to do; would they follow the suggestions of the Iroquois and move to areas under Iroquois control, or ignore the Iroquois and remain in the frontier on contested land? Gideon was a Delaware leader from the area of the Walking Purchase, who, alongside others, petitioned the Governor to stay in the contested area in 1742, on account of their Christian faith. ${ }^{105}$ The Moravians baptized Teedeyeskund and named him Gideon in 1750, and he used his connection with Moravians to remain in the contested area, moving into Gnadenhütten. Despite the baptism and acceptance of Gideon into the Gnadenhütten community, Moravian leaders had reservations about his personal character. ${ }^{106}$ His shifting alliances, whether political or religious, displayed opportunism; even his conversion,

105 MPCP, 4:624-25. Robert Peters, the same Provincial Secretary who forced the Delaware off 'his' land (Meniolagomekah) in 1754, did not believe the assertion that the group was Christian, and did not accept the request.

${ }^{106}$ Merrell, 91. 
symbolically a personal confession of faith, allowed him to remain in the traditional land of the Delaware, a goal he held for years before.

Paxnous, as another example, was the Shawnee leader of Wyoming. Historians who studied him portray Paxnous as an honorable and loyal friend to both the Moravians and the English. ${ }^{107}$ As the leader of Wyoming, Paxnous regarded the village of Gnadenhütten as a local ally. In 1752 he led his people, starving, to the village asking for aid, going to Gnadenhütten to save his village. ${ }^{108}$ His wife and sons must have felt a connection to the Moravian community and were baptized, although Paxnous himself did not convert. Perhaps by not converting, he could maintain political control of the Shawnee, by practicing traditional Shawnee religion. ${ }^{109}$ On Good Friday, April 12, 1754, Paxnous and a group of Shawnee came to the village and surprised the Moravians with a visit. When they arrived at the village Brother Joshua greeted them and asked about the reason for their visit, but this answer was not recorded, or perhaps not given. ${ }^{110}$ However, given that it was Holy Week it is possible that Paxnous had religious reasons to visit the Moravians, or at least he had religious excuses to be in the village. The Wyoming Indians stayed until April 19, 1754, and during that time the Shawnee went on hunts and interacted with the Native American converts. A portion of the Shawnee stayed to be with the Native Americans at Gnadenhütten while Paxnous left to visit Bethlehem for a few days. During

${ }^{107}$ Chester Hale Sipe, The Indian Wars of Pennsylvania: An Account of the Indian Events, in Pennsylvania, of the French and Indian War, Pontiac's War, Lord Dunmore's War, the Revolutionary War, and the Indian Uprising from 1789 to 1795 ; Tragedies of the Pennsylvania Frontier Based Primarily on the Penna. Archives and Colonial Records (Telegraph Press, 1929), 267; Anthony F C Wallace, King of the Delawares: Teedyuscung, 17001763 (Syracuse University Press, 1949), 81.

${ }_{108}$ Merritt, At the Crossroads, 155-56.

${ }^{109}$ Sipe, 267.

${ }^{110}$ MAB, MissInd 1.11.118.1, April 12, 1754. 
this visit, the Shawnee must have made an impression on the Indian Moravians at the village as several decided to leave and move to Wyoming.

On April 18, 1754, Gideon made the decision to leave Gnadenhütten and later became the de facto leader of the Delaware at Wyoming. He and his wife, Elizabeth, and their children, Joachim and Catharina, left with Abraham (who had already decided to leave a month earlier), Simon, Adolf, and Moses, senior and junior, to live in Wyoming. Schmick wrote: "one of our Indian brothers had a small meeting with the Shawnee. Brother Abraham, Gideon, Simon, Adolf, Moses senior and junior, and Joachim, explained that in five days they would go to live in Wyoming."111 This announcement happened the day after Paxnous returned to Gnadenhütten from Bethlehem, and the day before Paxnous and his Shawnee left the village. It seems evident based on the records that Paxnous, who did not meet and talk with the European Moravian leaders in Gnadenhütten during this visit, was there to have his group of Shawnee pressure the Native American Moravians to leave - the objective of the Iroquois.

It is doubtful that the move from Gnadenhütten was due to tribal animosity between the Mohican and Delaware, an assertion that Merritt made. ${ }^{112}$ While the Delaware from Meniolagomekah did receive permission to live in Gnadenhütten after Peters expelled them from their village, that occurred four days after Gideon, Abraham and other members left for Wyoming. Additionally, Gideon, a Delaware, was leaving with Mohicans, and Abraham and Moses (both senior and junior) and their families were Mohican. If the move to Wyoming was

${ }^{111}$ MAB, MissInd 1.11.118.1, April 18, 1754. "Nach diesem hatten einige von unsere Ind. Brüdern nach einen kleinen Rath mit der Shawanser, dabey sich Br. Abraham, Gideon, Simon Adolph, Moses sen. U jun. Joachim erklärten über 5 Tage nach Wajomick zum wohnen zukommen.“"

112 Merritt, 159, 165. 
due to the breakdown of the multi-ethnic village, it would not make sense that departures would be a multi-ethnic group, or that they would be leaving for another multi-ethnic village. The Iroquois Confederacy loosely held their allegiance to each other, but as we saw in Chapter One that connection was tenuous, and the Delaware, at least, were willing to work against the goals of the Iroquois. Potential enemies surrounded Gnadenhütten, but between July and November, there were few indications of the fighting that had begun in the West. The beginning of the Seven Years' War had not changed the goals or the mission of the Moravians, who were busy within their community.

The visits from powerful local Indian leaders continued, and on November 1, 1754, Simon, a Native American man from Wyoming, came to the village to let the Moravian leaders know that Paxnous was on his way. ${ }^{113}$ Unlike other visits from Paxnous, this time he was announced, "Indian Simon [came] with a message and wampum: Paxnous is on the road and will be here soon." Based on the formality of this introduction, we know this visit was important. Paxnous sent the messenger out ahead of the party, and several Native American leaders were present, including Nathanael the Mohican, who Moravian leaders removed from the village for his behavior with Salome. This was a multi-ethnic visitation from leaders of Wyoming: Paxnous, the Shawnee Sachem; Blackfish, a Shawnee leader who would be Sachem by 1777; Nathanael, a Mohican; and Gideon, a Delaware. Since the last two visitors, Nathanael and Gideon, were both prior inhabitants of the village, the group was surely aware of the village dynamic and the laws

${ }^{113}$ MAB, MissInd 1.11.118.2, November 1, 1754. "Zu Mittag kam der Ind. Simon als Bote mit einem String of Wampom u. den Worten: dass der Paxnouss unterwegens und bald hier seyn wird. Um 3 Uhr kam der alte Gideon hier an. Unser Ind. Conferencz=Brr. Und ich nebst Br. Christian hiessen sie willkommen u. Br. Jacob führte sie in sein Haus, allwo sie geffrisst wurde. Nach dem wurde ihnen ein apart Haus, worinn ein gutes feur gemacht war, zu ihrem aufenthalt u. Ruhe angewiesen.“ 
under which the Moravians lived and served, such as requiring permission from the Bishop in Bethlehem for any major undertaking.

On November 2, 1754, Paxnous, through the translations of Gideon and Jonathan, addressed the men in the Moravian congregation:

After a pause I took my place and welcomed Paxnous in the name of my brothers and said: You gave us notice that you would like to say some words, and we are now here to hear them. Jonathan the Mohican translated this. ${ }^{114}$ Here Paxnous thanked us and apologized that he could not speak to us directly, he brought Gideon with him to translate his words. Then he gave Gideon, who stood up, a string of wampum and said in Delaware: Brothers! I am glad that I am healthy in your house. I have visited my brethren in Maqualand, where the great words have been given to me for you, I will now tell you ${ }^{115}$.

(With the first string of wampum.) I have seen in Machawaomick my friends the Shawnee, Mohicans, and Delaware, with a fire I have made for them ${ }^{116}$. I was happy about it. The land is mine, and it shall be for as long as the world is.

This Jonathan repeated in Mohican and German, and also the following:

(With the second string said the speaker Gideon:) Brother! You know I said to you two years ago we have opened our lands, I will take my friends the Mohicans

\footnotetext{
114 This was the same Jonathan that had decided to stay in the village with his wife, Anna. 115 Maqualand is roughly modern-day Albany, New York. Maqua being the Mohawk.

116 Machawaomick is Wyoming.
} 
and Delaware with one hand and you will take them in the other hand; I have now taken a step and the city is still clear, they are now to live in Wyoming, it is my country I have given them, it shall be theirs, as long as the world stands.

(At the belt were these words:) I am the big one, I speak the truth and do not lie. I take up the arms of the poor, so that the way up to us is open, and with the sixteen heads of the Five Nations, have opened the Mohican and Delaware to my friends and seated them in the land of Machawaomick where I made a fire. The land is my own, it shall now be theirs as long as the world stands. Let them plant and think of God.

(At the third string:) Brother! You do not have to think of anything evil, you know we have been brothers for some time and still are, we look at each-other as one. You do not have to stop. When you think of it and see that your brothers dwell there, you see the way is clear, you can visit our friends there and stay there as long as you please, and then go to your country. And they may visit you, and stay with you as long as they please, and afterward go forth into their land which I have given unto them.

After this I stood up and said: Brother! I and my brothers have heard your words, understand and would like to think further over them. We sat together for a little 
while, and then everyone went apart. This message has caused many of the

brethren many thoughts and dissatisfaction. ${ }^{117}$

This interaction was, by far, the most explicit recorded interaction between the Native

Americans from Wyoming and the community at Gnadenhütten, and it revealed several

important features of this dynamic. This interaction showed that while the Delaware and

${ }^{117}$ MAB, MissInd 1.11.118.2, November 2, 1754. "Nach gehaltene Morgensangen gab ich dem Paxnous auf sein gestriges Verlangen zur Antwort, dass er heute Nachmittag dem Brrn. Seine mitgebrachte Worte sagen könne. Das war ihm lieb. Daraufgang ich nach der Mahoni u. notificirte eb den Brrn, dass der Paxnous sehr wohl zufrieden sey, wenn es heute nach geschähe, und dann ging ich wider nach Gdhütte. Um 2 Uhr kam Br. Lawatsch, Christian, u. Martin u Grube auch herüber. Wir hielten ein kl. Conferenz mit den dazu gehorigen Ind. Brrn. U. fanden vor gut dass des Paxnous Worte in gegenwart aller Ind. Geschw. in dem Haus wo er sich aufhielt, weil wir kein dazu aptirtes vor die Zeit haben, solle angehört werden. Dieses wurde dem Paxnous bekannt gemacht er war damit zufrieden, unser Ind. Brr. schaften gleich einige Bänke dahin, versammleten sich u. Brr. Lawatsch, Christian, Martin, Grube, u. ich nebst noch einege Brrn. Von der Mahoni nahmen als dann unsern Plaz auch ein Nach einer kl. Stille stande ich auf, hiess den alten Paznous im Namen meiner Brrn willkommen u. sagte: Du hast uns wissen lassen, dass du uns gerne wolltest Worte sagen, wir sind jetzt da selbige anzuhören. Der Jonathan Mahik. übersezte es. Hierauf er danckten sich der Paxnous, entschuldigte sich dass er in sr. Sprache nicht mit den Brrn werden könne, daero er den Gideon mitgebracht, der der Interpres seiner Worte u. Speaker sein sollte. Dann gab er denn Gideon eins String, welcher aufstrand u. folgende Anrede da seinem Paxnous Namen hielte: in Delawarischer Sprache. Bruder! Ich freue mich, dass ich gesund bin in dein hais kommen. Ich habe meine Brr. in Maquaischen Lande besucht, da hat mir das grosse haupt Worte an dich mitgegeben, die will ich dir nun sage: beim 1ste String of Wampom. Ich habe in Machawoamik meine freunde der Shawanoes, Mahikander u. Delawars bei einem feuer, das ich ihnen gemacht habe, sizen gesehen. Darüber habe ich mich gefreut. Das Land ist mein, u. es soll ihres seyn, so land die Welt stollt.

Dieses widerholte der Jonathan Mahikandisch und teutschl. U. so auch der folgende.

Beim 2te String sagte der Speaker Gideon: Bruder! Du weisst, ich habe vor 2 Jahren zu dir gesagt: wir haben unsere Lände aufgethan, ich will meine freunde die Mahikander u. Delaw. Bei einer Hand nehmen u. du solt sie bei der andern Hand nehmen; ich habe nun einen Schritt gethan und der Pfad ist noch klar. Sie sollen um in Wajomic wohnen, es ist mein land, ich habs ihnen gegeben, es soll ihre seyn, so lang die Welt steht.

Beim Belt. waren diese Worte: Ich das grosse haupt ich rede die Wahrheit u. lüge nicht. Ich unsern die wär Arme wider aus einander, damit der Weg bis zu uns offen ist, und habe mit den 16 häuptern der 5. Nationen meine freunde dir Mahik u. Delaw. Auf u. seze sie im des Lande das Machawomik heisst nieder, alwo ich ein feur gemacht habe. Das Land ist mein einen, es soll nun ihre seyn so lang die Welt steht. Da sollen sie pflanzen un an Gott denken.

Bein 3te String: Bruder! Du must nichts übels denken, di weisst wir sind seit einiger Zeit Brüder gewesen und sinds noch, wir sehen uns als einer an. Du musstes nicht hindern. Wann du dran denckst und siehst, dass deine Brüder da wohnen du siehst der Weg ist Klar, du kanst unser freunde da besuchen und bleiben so lang es dir gefällt (bis du mude bist) $u$. dann wider in dein Land gehen; und sie könne dich besuchen und auch bei die bleiben so lang es ihnen gefällt (bis sie müde sind), und darnach wider in ihr Land gehen, das ich ihnen gegeben habe.

Nach diesem stand ich auf und sagte: Bruder! Ich und meine Brr. haben deine Worte aufgehört, verstanden u. werden weiter darüber denken. Hierauf sassen wir nach eine kl. Zeit beisammen und dann ging alles auseinander. Diese Nachricht hat bei vielen Geschw. Manches Nachdencken und auch Unzufriedenheit verursacht." 
Shawnee in Wyoming may not have been happy with the Iroquois, the Shawnee leadership was still working to fulfill Iroquois goals. Now that fighting had finally erupted between the two major European powers in the area, the Iroquois sought to move the Native Americans so that they were under direct supervision by proxies of the Iroquois. By sending the leaders of Wyoming with wampum and messages, this was an overtly political visit, not one to predict the decision of the Moravians. Instead, the visitors explicitly told the European Moravians that it was time for the Native American Moravian converts to move to Wyoming.

This interaction showed several prominent issues between the villagers and Wyoming. First, Paxnous did not know the language of the Mohicans, Delaware, or Germans. Gideon, the Delaware, translated Paxnous' words into Delaware and Jonathan, the Mohican, translated the words into Mohican and German. It is possible that Paxnous knew Shawnee and Onondago (one of the Iroquois dialects), and possibly English, although this is improbable as he visited Gnadenhütten in 1755 without an interpreter and had to leave because he could not communicate with anyone, despite English spoken in the village.

Second, Paxnous told the Native Americans in Gnadenhütten that they had to move: "they are now to live in Wyoming, it is my country I have given them, it shall be theirs, as long as the world stands." The Iroquois in Maqualand, maybe even only the Mohawk, made this decision with Paxnous as their proxy, as Native Americans living in the contested land had dawdled for too long in their eyes. Now that fighting was imminent, the Iroquois wanted to ensure that possible Native American allies would be living within the political sphere of Iroquois power. This interaction was not a request, it was a demand.

Third, Paxnous claimed sovereignty over Wyoming, and did not see any future where he (or his successors) did not control the land. The land claim was so important it figured a prime role in each of the wampum recitations. Not only did Paxnous claim the land of Wyoming, he 
also claimed original rights to the land the Moravians currently occupied. With the third belt he said: "and go forth into their land which I have given unto them." This signaled the Moravians as interlopers on the frontier, given contested land solely based on friendship and alliances.

Fourth, Paxnous admitted that the Iroquois Confederacy had a vested interest in the Native Americans moving to Wyoming. The Shawnee and the Iroquois had "opened the way" for the Mohicans and Delaware to join the Shawnee in Wyoming, although Paxnous did not specify the mechanics in his speech. Additionally, Paxnous referred to the Iroquois Confederacy as the Five Nations, while, since 1722, it was comprised of six nations; the final being the Tuscarora, a southern tribe that moved north due to violence in the south. This could imply that Paxnous did not recognize the power of the new addition to the confederacy, or perhaps the smaller Pennsylvania tribes rejected the superiority of an interloping southern tribe. This also could suggest that the Iroquois Confederacy had unduly appointed the Tuscaroras to a place where they had no legitimate right.

Fifth, the Iroquois and the Shawnee were strong in their petition to the Moravians and their indigenous converts. They promised the Mohicans and Delaware land and freedom, and Paxnous, with the Wyoming leaders, assured the Gnadenhütten villagers that they would be welcome and able to continue living in a multi-ethnic community. They could retain their faith, visit, and interact with the European Moravians as much as they wanted.

Finally, the Iroquois and the Shawnee were impatient to hear the response of the Moravians. This should not be surprising since the Moravians had been promising a decision since at least 1753. Schmick, like the Moravian speakers before him, tried to placate them to gain some time. By requesting time to think over Paxnous' words, Schmick was trying to get more time for the church to decide what was best for the mission and its congregants. 
The nature of the message from Wyoming, and subsequently the Iroquois, could also be viewed as a warning. The Iroquois and the multi-ethnic delegation from Wyoming told the Native Americans in Gnadenhütten to move to an area within the Iroquois sphere of influence, while not stating the consequences should the Native American and European Moravians fail to follow these instructions. Years had passed where the villages (first Meniolagomekah and then the combined village of Gnadenhütten) dragged their feet and did not commit to any move. This political conference was meant to force the Moravians, both European and Native American, into a decision, and strongly suggest the solution that the Iroquois demanded of them.

On November 5, 1754, Schmick formally responded to Paxnous. Schmick and other Gnadenhütten leaders (Brothers Christian, Martin, and Grube) invited him to a small conference where Josua translated. ${ }^{118}$ Schmick and the Moravian leaders gave Paxnous a string of wampum and told the Wyoming leader that "we want all the words to go to great council in Bethlehem; all the chiefs should be together to send you an answer."119 According to the record, Paxnous was pleased and accepted the wampum, indicating they would wait in Wyoming for a response. Three days later, after Paxnous and Blackfish visited Schmick to thank him for the hospitality of the visit and the provisions for the return trip to Wyoming, and then Paxnous with the other Wyoming leaders left. ${ }^{120}$

118 There is no indication as to whether this was Josua the Mohican or Josua the Delaware, but he must have known Shawnee.

${ }^{119}$ MAB, MissInd 1.11.118.2, November 5, 1754. "Bruder! Ich und meine Brüder lassen dir wissen, dass wir alle Worte, die du uns aus dem Maquaischen Lande von unsere Brüdern, den 5. Nationen gebracht u. gesagt hast, gut verstanden u. behalten haben. Deswegen [gebeinach?] dir diesen String of Wampom. Wir wollen alle Worte im grossen Rath in Bethlehem, wann alle Chiefs beisammen seyn, wol überlegen, und als dann dir eine Antwort schicken."

${ }^{120}$ MAB, MissInd 1.11.118.2, November 8, 1754. It was interesting to see that Gideon did not visit with Schmick. 
This meeting exemplified the connection between the American Indians on the frontier and the Moravians. ${ }^{121}$ The Wyoming leadership addressed the Moravians initially with the Iroquois demands and then remained for several days. They attended religious services and visited with Schmick and other Moravian leaders. They accepted the answer of Schmick, that the religious leaders in Bethlehem would have to discuss the Iroquois demands, and then, once they completed their duty, stayed and interacted with the Moravians. These men knew each other well; they were neighbors and through the decade had helped each other and each other's communities. The intersecting loyalties at this moment were complicated: the Imperial forces of France and England were political rivals who attempted to ally themselves with Native American tribes; the Iroquois were traditionally allied with the English, thus the Shawnee and Delaware also had English connections, although they did not have total allegiance. However, these alliances were fluid and often depended on proximity to the European powers. The Wyoming leaders that came to demand the removal of the Moravian Indians, especially Paxnous and Gideon, showed two separate loyalties. Paxnous attempted numerous times to discuss increased tension among the American Indians with the European Moravians, indicating his connection to the community. Gideon, conversely, played at alliances with all sides to increase his personal power.

After this political visit, the Moravian village had few options. First, the Moravians could abandon the village and move to Wyoming, with their Indian converts. This would take them further away from the Moravian hub in Bethlehem, yet it might save the Indian villagers from

${ }^{121}$ MAB, MissInd 1.11.118.2, November 5, 1754. MAB, MissInd 1.11.118.5.3, Johan Jacob Schmick to Mattheus Hehl. 
harm and spiritual neglect. It would also put the congregation directly into a major Indian city, where they would have more people to convert. Alternatively, they could remain in Gnadenhütten despite the threats to the community. Given that there was no specificity to the threats, the Moravians may have believed that the Iroquois and their proxies were not sincere. A third choice would have been to abandon the village, leave the American Indians to their own politics, and return to Bethlehem. However, none of the Brethren in Gnadenhütten considered this option, showing their commitment to both the village and their missionary goals.

Throughout 1755 the neighboring Native American leaders continued to question the Moravians about whether the Native American converts were going to leave. In fact, many of the letters from Gnadenhütten to Bethlehem after the meeting in November of 1754 discussed whether the Moravians and their Indian converts should move from the contested land. The European Moravian leadership in Gnadenhütten continued to ask Bishop Spangenberg for an answer. Christian Seidel wrote to Bishop Joseph Spangenberg on January 24, 1755 and expressed the frustration the missionaries had with the lack of decision from Bethlehem: "Martin wants to...know the final resolution of the brethren. He said that it affects them and their work with the Indians." ${ }^{122}$

The Brethren at Gnadenhütten remained in contact with both the council in Bethlehem and with the village of Wyoming after the visit from Paxnous. In several of the letters to Bethlehem, the leaders of Gnadenhütten mention brothers leaving for Wyoming for many days.

122 MAB, MissInd 1.11.118.5.5, January 24, 1755, Christian Seidel to Joseph Spangenberg. "Unser Martin will auch...über ein und anderes eine final resolution bei dir u. den ander Geschw. absollen. Er betrifft hauptsächlich unsere nach [illegible] zu bewerk stellen." 
In a letter from Schmick to Spangenberg dated April 1, 1755, Schmick added in a postscript that Brothers Seidel and Frey left for Wyoming, and after their time there they would be traveling to Shamokin, a Native American town further west. He also noted that several Indians came to the village on the way through to Philadelphia without detailing their intentions. ${ }^{123}$ Meanwhile, the European Moravians in Gnadenhütten were still waiting for an answer from Bethlehem regarding the demands of the Iroquois. It was evident that the European Moravians, regardless of the decision from the leadership in Bethlehem, had decided to continue as they had and endeavored to create stronger ties to the Native Americans that lived near them.

Moravian letters described two additional visits from Paxnous in 1755. The first was April 6, 1755, and with the second following on July 20, 1755. On April 6, 1755, Paxnous visited Gnadenhütten and Schmick invited him and Abraham, the Delaware, into his house. ${ }^{124}$ The visit from Paxnous and Abraham in April was a stop on their way to Philadelphia to speak with Pennsylvania Governor Robert Morris. Schmick asked the Indian leaders if they would like him to send a letter to Morris to alert him to the visit, the number of travelers, and the intended message. Paxnous, through Abraham, responded that he would talk to the Indians from the Susquehanna, with whom they were meeting the next morning. Schmick remarked in the letter to Spangenberg how easy it was to interact with the Wyoming leaders without the unnecessary rituals that went along with the exchange of wampum. This aside to Spangenberg showed that while Schmick may have been willing to acquiesce to Native American cultural strictures, he

${ }^{123}$ MAB, MissInd 1.11.118.5.11, April 1, 1755, Johan Jacob Schmick to Joseph Spangenberg.

${ }^{124}$ MAB, MissInd 1.11.118.5.12, April 4, 1755, Johan Jacob Schmick to Joseph Spangenberg. Abraham was the man who gave the impassioned speech to leave the community in April 1754. 
was happier still to toss them aside. ${ }^{125}$ While Paxnous, Abraham, and Schmick conversed at Schmick's house, Paxnous again inquired after the Moravian answer to the earlier November meeting. Schmick then wrote to Spangenberg that he informed Paxnous to the rules of the order. ${ }^{126}$ This non-answer was a reminder that the decision was not Schmick's to make, but rather he, like Paxnous, had to wait for the decision of the religious leadership in Bethlehem.

Paxnous was not the only American Indian to visit Gnadenhütten seeking the Moravian response to the demands of the Five Nations. On July 13, 1755, Schmick wrote a letter to Spangenberg which told of a visit from the Indian Toto, an acquaintance of a woman known as old Naemi, a Delaware convert. ${ }^{127}$ According to Schmick, Toto and his sister arrived on the evening of July 12, 1755 and came with the express intent to learn whether the Moravians would be leaving Gnadenhütten. Schmick did not write that Toto received any answer, perhaps indicating again that the Moravian council had not yet decided. ${ }^{128}$

A week later old Naemi, a friend of Johanna Schmick, came to take communion with the village. ${ }^{129}$ Schmick did not go into detail in this letter on the conversation that the brothers and sisters had with Naemi, yet he asked Spangenberg if they should not listen to the friendly Indians. ${ }^{130}$ This indicates that Native Americans who visited the village, like Naemi, were openly advising the Moravians, without specifying the exact nature of the advice. Schmick did not seem

\footnotetext{
${ }^{125}$ MAB, MissInd 1.11.118.5.12, April 4, 1755, Johan Jacob Schmick to Joseph Spangenberg. ${ }^{126}$ MAB, MissInd 1.11.118.5.12, April 4, 1755, Johan Jacob Schmick to Joseph Spangenberg.

${ }^{127}$ MAB, MissInd 1.11.118.6.2, July 13, 1755, Johan Jacob Schmick to Joseph Spangenberg.

${ }_{128}$ MAB, MissInd 1.11.118.6.2, July 13, 1755, Johan Jacob Schmick to Joseph Spangenberg.

${ }^{129}$ MAB, MissInd 1.11.118.6.3, July 20, 1755. Johan Jacob Schmick to Joseph Spangenberg.

${ }^{130}$ MAB, MissInd 1.11.118.6.3, July 20, 1755. Johan Jacob Schmick to Joseph Spangenberg.
} 
to trust that the Brethren were giving full credit to the information that the American Indians were giving them at the village.

The same day that Schmick wrote to Spangenberg about Naemi's visit, Christian Seidel, another Moravian leader in Gnadenhütten, also wrote to Spangenberg. ${ }^{131}$ Seidel wrote that Paxnous also visited the village that day, but there was no interpreter, so he left without being able to explain his message. Seidel also mentioned that the Shawnee were experiencing riots and turmoil. ${ }^{132}$ We do not know where Seidel received the information about Shawnee turmoil, although it is doubtful it would have come from Paxnous, since he could not communicate with them; it could have come from Naemi. The diary also did not record if this turmoil was impacting Shawnee in Wyoming, or those further in the West.

It is evident that as of November 20, 1755, the Moravian council had still not decided on the course for Gnadenhütten. Whether Moravian leadership did not believe the repeated warnings they received, or whether they made the decision as missionaries to remain with their flock, the Moravians remained in Gnadenhütten. Four days prior to the attack on the village of Gnadenhütten, on November 20, 1755, Grube wrote a letter to Spangenberg, the last letter to mention the Native American villagers before the attack. Grube wrote that most of the village Indians left to go on a hunt because the children were crying due to hunger. Anton and his family, however, decided to remain at the village: "Our dear Anton and his family said that they would remain here and die along with the brothers." 133 This letter showed that the villagers were

${ }^{131}$ MAB, MissInd 1.11.118.6.5, July 20, 1755, Christian Seidel to Joseph Spangenberg.

${ }^{132}$ MAB, MissInd 1.11.118.6.5, July 20, 1755, Christian Seidel to Joseph Spangenberg.

${ }^{133}$ MAB, MissInd 1.11.118.6.27, November 20, 1755, Bernhard Grube to Joseph Spangenberg. 
suffering from starvation — or at least the fear of it. It also showed that some of the Native Americans were so devoted to the village and the European Moravians that they were unwilling to leave them, even if it meant death. ${ }^{134}$ Based on the letters from Gnadenhütten to Bethlehem, there was little evidence that the Native American villagers were aware of the impending attack on the village, and no evidence that the European Moravians were.

\section{Attack on the Village}

On November 24, 1755, while the Moravians were preparing to have dinner in the Communal House, a band of Native Americans attacked the village of Gnadenhütten. The attack destroyed the village and left eleven European Moravians dead. On November 27, 1755, the Pennsylvania Gazette published the first account of the attack in the newspaper. At first, the details were sparse:

Yesterday an Express arrived here from Easton, in Northampton County, with Advice, that the Moravian Settlement of Gnadenhutten, on Mahony [sic] Creek, is cut off by the French Indians, and that two of the People only escaped. On receiving this Intelligence at Easton, they immediately sent over to the Jerseys to Colonel Anderson, requesting him to send some Men to their Assistance; upon which he immediately came himself with a Company, and marched in Pursuit of the Enemy, as he did most readily on a late Occasion of the same Kind. At the same time a Number of the Inhabitants of

${ }^{134}$ Another important thing to note is that this information, as always, is coming from a second-hand source. Grube, and the Moravian missionaries generally, may have had reasons to exaggerate or not question the reasoning of their Native American converts. 
Northampton got under Arms, and went likewise in Search of the Indians. ${ }^{135}$

The newspaper claimed French Indians surrounded the village, only two people escaped, and white neighbors rushed to help their Moravian counterparts by gathering arms as vigilantes. It seemed likely to the reporters that the attack was the result of French Indians' retaliation against an English allied village. There may not have been overt evidence, but given the war to the west, and the fact that Indian groups had already attacked several European towns, they placed blame on French allied Indians. The Provincial Minutes recorded several attacks on Europeans and English allied Indians since October 1755; in the month before the attack on the village at least twenty-nine men and women were the reported dead after raids in the area. ${ }^{136}$ It is not necessarily true, however, that the French were behind these attacks. It is more likely that the English, feeling that the French were more powerful than they were, placed blame on their Imperial rival for actions that grieved and dispossessed Native Americans did on the contested land.

On December 4, 1755, the Gazette published the next report on the attack. It gave a thorough account of the attack, presumably based on a report from one of the survivors who was able to escape to Easton. According to the column five women and a man burned in the building. The Indians shot, beat, and scalped a man outside of the common house, and burned everything, including the houses, barns, hay, horses, and 40 head of cattle. ${ }^{137}$ The paper also suggested that Colonel Anderson and the New Jersey militia might have been able to prevent the attack.

135 “Attack on Gnadenhütten," The Pennsylvania Gazette, November 27, 1755, Accessible Archives. 136 MPCP, 6:766-67.

137 "Colonel Anderson and the New Jersey Militia," The Pennsylvania Gazette, December 4, 1755, Accessible Archives. 
However, Anderson heard that there may be as many as 500 enemy Indians waiting over the mountain ridge, so he withheld his troops. ${ }^{138}$ The Pennsylvania Gazette also reported on December 4, 1755 that Moses Tatamy, a Christian Indian and friend of the Moravians, acknowledged that the local Indians knew of an imminent attack. ${ }^{139}$ Tatamy told the Gazette that on November 22, 1755, two days prior to the attack on the village, Native Americans told local Indians that the "Gap of the Mountain was then open, and would remain so all the next Day, to give a free Passage for all the Indians in that Neighborhood to return to their Friends at Nescopecka." This message to the Indians also held a direct threat to the Native Americans of the area, "if they refused this Invitation, they would meet with the same nay worse Usage than the white People." 140

This warning to the local Native Americans came two days after the last letter that Grube sent to Bethlehem. This was not a generalized warning, nor was it a continuation of the suggestions Moravians had received from their neighbors. This was a direct warning that unless the Indians in the area moved to Nescopeko, they would suffer the same violence as the Europeans in the frontier. This warning could be why there were no Indians in the village of Gnadenhütten on the night of the attack, as they were aware of the violence heading their way and knew that their presence could bring more violence to the village and their fellow

138 "Colonel Anderson and the New Jersey Militia."

${ }^{139}$ Merrell, 88, 90; "Moses Tatamy Affidavit," Pennsylvania Gazette, December 4, 1755, Accessible Archives. Moses Tatamy was a local landowner who owned over 300 acres of land at the forks of the Delaware River. Prior to the rise of Gideon, the Moravians and English looked to Tatamy as a leader of the Delaware. Zinzendorf admired Tatamy for being a "quiet and honest" man, a characterization that the newspaper agreed with: "Moses Tatamy, an Indian Convert to the Christian Region, who bears the Character of a sober, honest, and conscientious Person...". After Gideon's political maneuverings, which led him to gain control of the Delaware factions, Tatamy became Gideon's follower.

140 "Moses Tatamy Affidavit." 
Moravians. It is also possible that they believed that by not being in the village the offending Indians would spare their European counterparts' lives. Perhaps if they hid, one might imagine, their attackers would have taken their disappearance as sign that they accepted the 'invitation' to Nescopeko. Additionally, according to Tatamy's affidavit, he was aware that the attack would cut off Gnadenhütten from the rest of the backcountry.

It seems likely that the multi-tribal groups in Nescopeko were the perpetrators of these attacks. The fact that Moses claimed Nescopeko would remain open for displaced Indians strongly suggests that they were at least involved. Nescopeko, like Wyoming, had united with the Iroquois, and was the other primary destination for the Gnadenhütten Indians left for in 1754. Further in Moses Tatamy's affidavit, he remarked that displaced Indians "of the above Nations (Allegheny, Shawanese, Mohawks, Tuscarora, and Delaware)” were settling in Nescopeko. ${ }^{141}$ This indicates that local Native Americans, with whom the European Moravians had a strong connection, had either turned on the village and its inhabitants or faced a major leadership coup. ${ }^{142}$ Additionally, the Mohawks and Tuscaroras were two of the Six Nations, part of the Iroquois Confederacy. The Iroquois Confederacy was supposedly allied with the English, but, as we saw with the Delaware and Shawnee, the Iroquois did not have total control of the nations even within the Confederacy. It is probable that the Iroquois groups in Wyoming and Nescopeko were frustrated with the dalliance of the Native Americans in the Moravian village and meant to send a message to all the Native Americans in the contested frontier.

141 "Moses Tatamy Affidavit."

142 On the visit from Paxnous in April 1755, Paxnous warned about the rising tensions among the young men in the village. This could have been indication that the friendship with the Germans and the English was not popular among the village. 
Moses Tatamy's affidavit showed that the Native Americans in the frontier were willing to hurt other Native Americans, especially those who did not follow the directions of the Iroquois by moving to the Native American villages where they could be controlled and monitored. The Native Americans who remained had not followed directions and decided to stay in the contested frontier, and this group obviously included the Moravian Indians who remained with the Brethren in the village of Gnadenhütten. Tatamy named this raid on Gnadenhütten as the first planned attack.

Tatamy's statements showed that Iroquois allied Indians targeted the Moravians because they, and their Native American converts, refused to follow Iroquois directive to leave the contested land. This refusal showed the successful creation of a community; despite the threat of violence, the inhabitants were determined to live together in a peaceful community. The attack demonstrated that the Native Americans in the Iroquois controlled areas were willing to punish Christian Indians who did not follow orders. The Moravians, both the Europeans and their Native American converts, created community that had up until this point withstood the demands of the Iroquois. While not all the Native Americans in Gnadenhütten remained in the village, political reasons were not always the only reason why people chose to leave or stay, as the correspondence detailed in previous sections illustrated.

The Pennsylvania Gazette placed the blame for the attack on a unified American Indian front. In this alliance, the Gazette included Allegheny, Shawnee, Mohawks, Tuscarora, and Delaware Indians, tribes that were part of the Iroquois Confederacy or traditionally Iroquois allied. The records have shown that the Shawnee and Delaware were among the tribes with the most interactions with the Moravians, and Gideon and Paxnous were their leaders. Gideon, the 
chief of the Delaware, was a Moravian convert and Paxnous, while not converting to Christianity, had a wife and two sons who converted and worshipped with the Moravians. ${ }^{143}$ Gideon, his wife Elizabeth, and their family left the village at the same time as Abraham and Sarah, in April 1754. There was little evidence in the diaries as to why Gideon left. However, given the fact that Gideon gained considerable political power after his move to Wyoming, it is probable that he left to cultivate personal power at a time when the Moravians and Europeans were facing obstacles. Once the tide turned against the Moravians, and the American Indians began to unite against the local European settlers, he quickly changed sides, from Moravian and Iroquois in November of 1754 to French allied the next year. On December 10, 1755 Gideon declared against the English and threatened Paxnous when he petitioned the party for peace. ${ }^{144}$ He turned against the Moravians and the English, and even attempted to find French supporters within the Iroquois, to little avail. ${ }^{145}$ Gideon's political maneuverings are those of a man who wanted power, not a man who wanted peace. This may explain why initially Paxnous came with Gideon as an interpreter, yet later Paxnous visited the village of Gnadenhütten alone, without any one to interpret their German for him, or his Shawnee for them. Paxnous, unlike Gideon, never lived in the village, although he shared a good relationship with the European Moravians and all the villagers. These connections to the village were apparent when Gideon and Paxnous interacted with the village prior to the attack. However, it is probable that at a certain point that Time, 28.

${ }^{143}$ Drake, Biography and History of the Indians of North America, from Its First Discovery to the Present

${ }_{144}$ Wallace, King of the Delawares: Teedyuscung, 1700-1763, 81.

${ }^{145}$ Wallace, 81. 
Paxnous lost control of Gideon and the youth in their communities, just as Paxnous warned in 1755.

Despite these changing alliances, many of the Native American converts remained connected to the Moravians both before and after the attack. Based on the letters from Gnadenhütten to Bethlehem, it is evident that the local friendly Native American population attempted to warn the Brethren. These local American Indians were aware of the political turmoil occurring within their own population, the anger towards the European settlers, especially among the young warriors, and the larger Imperial forces that were at play on the continent. While political manipulations may have tainted the warnings, the fact that the Shawnee and Delaware attempted to warn the Brethren indicated that they felt a sense of obligation to the Moravians. Paxnous, the presumably deposed leader of the Shawnee, tried several times to confer with the Moravians. He came, even without an interpreter, to warn them of strife within the American Indian community. Old Naemi, the friend of Johanna Schmick, came to discover what the Moravians planned to do: whether they meant to remain in Gnadenhütten regardless of the danger, or remove themselves to Wyoming. These interactions showed a regard for the Moravians within the Native American community, as well as a desire to know the decisions of the European neighbors.

The Moravians, in turn, refused to leave the area while the Native Americans remained in harm's way. This was indicative of a successful mission, with trust and loyalty forming between the two groups. The Moravians were aware that they faced danger, yet they maintained their pacifistic stance even within the turmoil. Their Indian converts may have left the village, but 
once Zeisberger told them of the attack he had to stop them from immediate revenge. ${ }^{146}$ These Christian Indians seemed to place loyalty in faith over loyalty of race, identifying as members of the larger Christian community, as well as members of the Indian community.

Results of the Attack

After the attack on the village, and the death of nearly a dozen Moravians in Gnadenhütten, the remaining villagers fled to Bethlehem. The Gnadenhütten Indians petitioned the Pennsylvania government for protection. The letters that Governor Morris received from the Christian Indians of Gnadenhütten showed that the Christian Indians were committed to the community they built with the European Moravians. Christian Indians formerly of Gnadenhütten, currently of Bethlehem wrote a letter to Governor Morris that explained their fears. ${ }^{147}$ Fourteen Native American male converts marked this letter, under witness by Grube, Schmick, and John Okely, and given to Timothy Horsefield, Esq., a Justice in Northampton County on November 30, 1755. The letter represented several Moravian Indian groups, but the Mohican and Delaware were the most dominant; five Mohican, five Delaware, three Wampanoag, and one Minisink. There were no signatures from Shawnee converts, which did not suggest that the Shawnee were culpable for the attack, but rather reflected that were fewer Shawnee converts in the village than there were Delaware and Mohican converts. Conversely, neither did the inclusion of Delaware and Mohican signatures imply that Delaware and Mohicans were not involved with the violence.

146 Day, Historical Collections of the State of Pennsylvania, 178.

${ }^{147}$ MPCP, 6:747-49. 
While this letter does not denote what group or nation was responsible for the violence against the village, it demonstrated several things. First, the men (and presumably the women with whom they were associated) considered themselves Christians and Brethren: "But now it has come to pass that wicked People who serve the Devil have committed horrible Murthers \& inhumanly butcher'd even our own Brethren.” They separated themselves from other Native Americans with the words "wicked" and "inhumane". They recognized both the beliefs and the actions of the offending Native Americans were different than their beliefs and actions: "We well knew that we had nothing better to expect at their hands as long as we continued with the Brethren under this Government." These fourteen men declared that they "lived in Quiet \& Peace" indicating that they were living differently than many other Native Americans in the area, "burdensome to none". ${ }^{148}$

Second, the Moravian Indians admitted that they fled the village to avoid the attack, saying "We sought to save our Lives by Flight, leaving every thing behind which we had in Gnadenhutten...fleeing in the dark night naked \& empty away with our Wives \& Children.” They were aware that they were being targeted due to their alliance with the Moravians and English: "We well know that we had nothing better to expect at their hands as long as we continued with the Brethren under this Government." 149 The affidavit of Tatamy coincided with this - other people singled out the Moravian Indians as being traitors to their own people. It is probable that the signatories did not expect the European Moravians to die in the attack

\footnotetext{
148 MPCP, 6:747-49.

${ }^{149}$ MPCP, 6:747.
} 
(although since October 1755 raiding Indians killed over a dozen Europeans and Native American allies), as they thought the offending Indians were targeting only Indian Moravians.

Third, they had decided to remain with the Moravians, regardless of the actions of other Native Americans in the frontier, and "willing rather to suffer and live with them as heretofore". ${ }^{150}$ The use of shared experiences, shared culture, and shared goals created a community that even the violence of the beginning of the French and Indian War could not destroy. These men and their families chose the Moravians as their family.

Fourth, they petitioned the Governor and the state for protection. They recognized that their attachment to the Moravians made them vulnerable. Not only were they threatened by the Native Americans who were retaliating against Europeans, but also by Europeans who were unable (or unwilling) to recognize the differences between Indian polities. By allying themselves with the English they were denouncing the actions of English enemies, now also Moravian Indian enemies.

Governor Morris' response, dated December 4, 1755, showed that he accepted their petition, and believed that they had nothing to do with the attacks on the villages in the frontierincluding that of their home village. "I have not the least suspicion of your having been concerned in the late Mischiefs," he wrote, "Your precaution \& flight are an Evidence of your Innocence, \& I take in good part your Professions of Truth and Fidelity to your Brethren, and thank you for them."151

\footnotetext{
${ }^{150}$ MPCP, 6:747-49.

${ }^{151}$ MPCP, 6:750.
} 
By December of 1755, the English blamed the shifting allegiances on the promises of the French and the defeat of General Braddock in the Ohio River Valley. They wrote:

All our accounts agree in this that the French, since the defeat of General Braddock, have gained over to the Interest the Delawares, Shawonese, and many other Indian Nations formerly in our Alliance, and on whom, thro' fear and their large promises of Rewards for Scalps and assurances of re-instating them in the Possession of the Lands they have sold to the English, they have prevailed to take up Arms against us, and to join heartily with them in the execution of the ground they have been long meditating of obtaining, the possession of all the Country between the river Ohio and the river Susquehanna and to secure that possession by building a strong Fort at Shamokin, which by its so advantageous situation at the Conflux of the two main Branches of Susquehanna (one whereof interlocks with the waters of the Ohio, and the other heads in the Center of the Country of the Six Nations) will command and make the French entire Masters of all that extensive, rich and fertile Country and of all the Trade with the Indians. ${ }^{152}$

Yet, evidence from the Provincial Minutes showed that the Iroquois and their English counterparts never had full control of the Shawnee and the Delaware - the two major factions in Wyoming. The attackers of Gnadenhütten included factions of Iroquois, the Mohawks and Tuscarora (who were full members of the Six Nations), who were supposedly allied with the English. It is more probable that the Iroquois supported the local Native American groups who

\footnotetext{
152 MPCP, 6:768.
} 
were proving a point to the Moravians and their Native Americans converts. The Moravians defied the desires of the Iroquois, continued to live on the contested land, and did not even deign to give the local Native American leaders, Iroquois proxies, an answer to the continued requests to move. Additionally, the increased population of these villages, Wyoming and Nescopeko, would increase the political power of the village leaders in the eyes of the Iroquois.

The Moravian Indians remained devoted to the community they built with the European Moravians. After the attack on Gnadenhütten, the backcountry of eastern Pennsylvania became more violent; the English and the French allied Indians fought throughout the countryside, and alliances were fluid. In mid-January 1756 Governor Morris wrote about the beginning of the construction of Fort Allen, on the ruins of Gnadenhütten: "Yesterday and the Day before I received the melancholy News of the Destruction of the Town of Gnadenhutten, and of the greatest part of the Guard of forty Men placed there in order to erect a Fort."153

\section{Conclusion}

The Iroquois and their political proxies spent the years leading up to the attack on Gnadenhütten trying to remove the Moravians from the contested land of the frontier. The pressure to leave was so great that many converts left the village in April 1754. The decision to leave was not purely political, in fact, there seems to have been distinctly personal reasons (like access to family) that played a role in decision making. Some scholars, like Merritt, consider the exodus a sign of a failed community, yet I consider it a successful community despite the exodus. While some Native Americans decided to leave in the face of the political pressure,

\footnotetext{
${ }^{153}$ MPCP, 4:772.
} 
others did decide to stay. The community continued, and even those who left the village still interacted with the village on a frequent basis, as evidenced by the continual visits from Abraham and Sarah. While it seems probable that there may have been a gendered and/or generational divide between those who decided to leave and those who decided to stay, there is, unfortunately, little direct evidence of this. The diaries did not list those who left, their ages, or their marital status.

The attack on the village of Gnadenhütten, and the deaths of eleven German Moravians, was the direct result of this community's defiance of the Iroquois. While some contemporary accounts placed blame on the French allied Indians, the evidence shows that it was more likely that Iroquois allied groups were responsible for the attack. The Iroquois and their proxies tried for months to force the Moravian Indians out of the village of Gnadenhütten and into Native villages that had direct connection to the Iroquois. This pressure led to scores of Moravian Indians leaving the village, but it did not destroy the community; many Native American congregants remained with the European Moravians. The Iroquois eventually directly threatened the Moravians in the year prior to the attack. However, the Moravian Indians who chose to remain with the Moravians despite the threats of the Iroquois and their proxies showed that the community they created was important enough for them to face this possible retaliation of the Iroquois and other Native American groups.

Moses Tatamy reported the warning that the local frontier natives received prior to the attack. The warnings declared that the way to Nescopeko and Wyoming would remain open for the Indians to flee, indicating that those were safe places to flee to, and those who remained on the contested land would face retaliation. The Moravian Indians, possibly hoping that their European counterparts would be safer without them in the village, fled into the forests to avoid the attack. It is probable, given Tatamy's affidavit, that the Moravian Indians felt that they would 
be more at risk from the Native American raid than the European Moravians. Since the Europeans were not the actual target of the attack, the Moravian Indians could have assumed that the offending Indians would spare the European Moravians if the Moravian Indians were not in the village. While some historians might argue that the Moravian Indians leaving the village showed a lack of commitment to the village, I believe that the motive of protecting their European counterparts showed the cohesion and care of a connected community. 


\section{Part II: Philadelphia}

Part one focused on the creation of community between the Native Americans and the Moravians in the village of Gnadenhütten at the beginning of the French and Indian (Seven Years) War. Part two will look at the same community, its removal from the frontier, its internment in Philadelphia at the end of the war, and its movement to a new location, Friedenshütten. While technically the war was over in 1763 , and the war removed many Native Americans from the land that was traditionally theirs, the violence that occurred during war did not begin or end with an agreement.

Chapter four will look at the macro-history of the region and then narrow in scope to our Moravians and their Native American converts. Chapter four argues that despite the end of the war, the Native American converts were as endangered as they were prior to and during the war. It uses the Provincial Minutes, Moravian letters, community records, and newspaper articles to prove that the Native Americans, were still committed to the community they had created a decade prior, despite increased threats from settlers. Chapter five argues that the internment in Philadelphia put more strain on both the colony and the Moravian congregation. Both groups, the Pennsylvania government and the Moravian congregation, wanted the Moravians out of Philadelphia, yet the Governor and the Assembly decided that the threat to the Moravian Indians outside of the city was too great. This chapter uses the communal diaries, Provincial Minutes, and Moravian letters to show how Pennsylvania politics kept the Moravians in Philadelphia. Chapter six argues that during the Philadelphia internment, the community was beginning to see signs of wear, but overall was able to maintain community cohesion. The community that was strengthened by shared culture, experiences, and goals, no longer shared some of those goals, and internment was beginning to wear on the community. While interred in Philadelphia the community faced internal strife that was not overcome until they left for the frontier and, once 
again, had common goals. This chapter will use the communal diaries, and Provincial Minutes to prove that the community was in turmoil during their internment, only to become more cohesive again after their release. 


\section{Community in Danger}

\section{Movement to Nain}

This chapter argues that the Native American Moravian converts were at least as endangered at the end of the war as they were at the beginning of the war. The European Moravians, conversely, were less in danger. The tide turned against the Native Americans and within another decade the government and settlers would push them out of Pennsylvania. First, this chapter observes the movement of the European and Native American Moravians to a new village, Nain. Next, this chapter will focus on the rise of vigilante groups like the Paxton Boys and their actions against Native Americans, which led to the Moravians once again petitioning the Governor for protection. Then it will explore how violence in the west combined with the continued violence in the east, and how this violence affected those living on the eastern frontier. This chapter will finish with the Governor's decision to remove the Moravian Native Americans from Nain and Wechquetank, a neighboring village in the north, to Philadelphia. The resulting backlash of colonist and Indian fighting led to the movement and internment of Moravians, including Schmick and his Christian Indian congregation.

After the destruction of their village the Moravians from Gnadenhütten moved from between the Blue Mountain ranges into Bethlehem. This move caused general unease among the Moravians who were living in Bethlehem. The Bethlehem Moravians were worried about who was responsible for the attack on the village, the continued interactions with Native Americans in 
Wyoming, and the fear of French Indian retaliation against the refugees. ${ }^{1}$ By 1757 the

Gnadenhütten Indians lived in Bethlehem for over a year, and the city was searching for a

permanent arrangement. ${ }^{2}$

Moravian Indians contacted Governor Morris (1754-1756) about relocating the Christian

Indian population away from the city of Bethlehem. The Governor agreed that the Indians could leave Bethlehem, if they remained under Moravian observation. ${ }^{3}$ While this solution may have pleased the Moravians, there were other people involved who questioned the move. ${ }^{4}$ In 1758 the Moravians created a new village, Nain, which was one mile west of the city of Bethlehem. The creation of this new village led to continued community building, but also to controversy. When the congregation established the village, the Seven Years' War was still underway. The continued fighting meant that in most instances Native Americans and Europeans had lost the trust that they had prior to the onset of the war. The result was that the European immigrants distrusted their pacifistic Moravian neighbors, which put the Moravians at risk.

\footnotetext{
${ }^{1}$ Joseph Mortimer Levering, A History of Bethlehem, Pennsylvania, 1741-1892 (Times publishing Company, 1903), 352.

${ }^{2}$ Levering, 352.

${ }^{3}$ Levering, 353.

${ }^{4}$ Gideon, the Delaware man who left the village in 1754 and became a powerful figure in Wyoming, claimed that the Moravian Indians were Moravian hostages. His desire to remove the Moravian Indians from the oversight of their European counterparts and lead them back to Wyoming existed both during and after the war. Gideon decided that he and his followers needed to remain at Bethlehem for the winter to maintain watch over the Moravians. By May (1758) Gideon and his followers failed to convince the Moravian Indian converts to accompany them back to Wyoming, and they left Bethlehem. The fact that Gideon lived outside of Bethlehem in 1757-1758 could indicate that the Moravians did not believe that he was personally involved in the destruction of the village of Gnadenhütten. However, the fact that he was there to monitor the Moravians, could be seen as supporting the belief he was involved, since it seems that he did not trust the Moravians or their motives. Levering, 353-358.
} 
There are few records from Nain, mostly lists of Native Americans and lists for communion, where the catalogs of inhabitants showed several tribes represented. There are a few pages of diary excerpts, from 1759, 1760, 1762, and 1763 written by Schmick and Grube, where they summarized the notable events of the village. There are also catalogues of Native Americans which named village members, their status within the congregational Choir, and their communion status. These catalogues showed an active community even with the violence raging around them. A year after the establishment of the village, there were one hundred and sixteen participating members in the community. Some of these members were people who chose to return to the fold.

The summarized diary written by Schmick in 1759 showed that there were several individuals who "had left us during the diaspora" in 1754 and who returned in 1759. This homecoming showed the power of the community that the Moravians had created. ${ }^{5}$ There was no indication in Schmick's memo about why some Native Americans returned to the community. This was still during the fighting of the French and Indian War, three years before the European powers signed the Treaty of Paris. Therefore, it seems unlikely that the Moravian Native Americans returned due to military defeat. It is possible that those who returned wanted to remove themselves from Wyoming and return to their European and Native American Moravian friends. ${ }^{6}$ It could be that by this point the Native Americans who returned recognized that by

${ }^{5}$ MAB, MissInd 1.20.125.2.1, "Die erfreüliche Rückkehr einiger unserer bisher verirrten und verführten aus der Diaspora bei Nazareth und Friedensthal, die gangen die Wunde Jesu kalt und unempfindlich, und auf erhalten Erlaubnis ergezogen sind, mit der condition dass sie knüftigen Jahr über die blaue Berge auf ein stück land der Brüder hinziehe und da wohne sollte."

${ }^{6}$ Given the tension between Gideon and his followers and the Moravians, this seems possible. 
allying themselves with the Moravians again they would be able to retain access to their traditional land. It could also be that they missed their old lifestyle with their Moravian friends and decided to return to it.

While there is no evidence as to why some of the Moravian Indians who had left the village in 1754 returned, and no indication as to how many returned, it is important to recognize that Native Americans decided to return to a multi-ethnic community. They could have chosen other communities, yet they returned to the Moravians. This indicates that at some level they missed the community, the brethren, or the connections they created in the community. They could have remained in the Native American communities where they had moved in 1754, moved further into the Iroquois sphere of influence, or even moved into other Native American communities away from the Moravians; but they chose to come back into the Moravian fold.

As in Gnadenhütten, the primary goal of the Nain Moravians was to keep the paths open, fostering community and connection, and, gaining new converts. The few diary entries that we have showed that the Moravians were still meeting this goal. On January 2, 1763 Schmick wrote about Homawahnen, Salome's husband, who wanted to get baptized. ${ }^{7}$ Homawahnen told Schmick that: "he thought a lot on his love of the Savior, and about his love of his children who were here, and wanted to hear of the Savior and have his sins washed in the Savior's blood."8

${ }^{7}$ MAB, MissInd 1.20.125.3.1, January 2, 1763. There is no indication if this was the same Salome who was removed from Gnadenhütten for being a seducer-but it is possible that it was, especially if she were one of the ones who had been readmitted to the flock.

${ }^{8}$ MAB, MissInd 1.20.125.3.1, January 2, 1763. „Der Salome ihr alte Mann, Homawahnen genannt, sagte dass er ein gros Verlangen habe dHLDS zu lieben, u. so als s. Kinder zu leben, darum wäre er hier, höre gern von HLD u. wunsche dass er sich über ihn erbarmen, u. mit sei Blut von allen Sünden waschen möge.“ 
This entry showed that Homawahnen wanted to join the ranks of the baptized in the community. Baptism in the community, while ideal, was not a requisite. Homawahnen could have lived in the community with Salome without baptism. That same day Schmick noted that five women went to Johanna and begged, through tears, to have the Moravians baptize them. This showed again the vital role of European Moravian women as intermediaries between the Native American women and male leaders of the community.

The written accounts from the village also showed that there were still interactions between villagers in Nain and outside Native Americans. It should not be surprising that, despite the violence of the war, the Moravians continued to visit with and host other Native American groups. In 1759, Schmick wrote a few pages on the main events of the year for the village. These accounts confirmed that there were various visits from Indians from the Susquehanna region who came to visit the village to hear the good word. Schmick wrote that these people came away with a deeper meaning of the gospel—although how he did not write how he knew this. ${ }^{9}$ However, the local European American population did not trust these visits with outside Native Americans, and the continued presence of Native Americans from the Susquehanna. Instead of the Europeans realizing that the actions of the Moravians were merely a continuation of their missionary activity, they saw the visits between the Moravian Indians and the Native Americans who lived on the Susquehanna as suspicious.

\footnotetext{
${ }^{9}$ MAB, MissInd 1.20.125.2.1.
} 
A summarized memorandum of April and August 1760, written by Bishop Spangenberg, also showed the continued interaction between the village and the Native Americans on the Susquehanna. ${ }^{10}$ This memorandum seems to be notes that Spangenberg asked while reviewing the community diary — which no longer exists. Spangenberg was in Bethlehem but was monitoring the Nain interactions. Spangenberg followed the short entries with questions that he and the church found important. On April 7, 1760, Spangenberg wrote of the arrival of several drunken foreign Indians: "In the evening several foreign Indians came here. Many were drunken. Question: what is there to do?"11 It did not seem that he was offended by their behavior, particularly. At least, not enough to demand Moravians keep the offending Indians from the village. Nor did it mention why the foreign Indians were visiting. We cannot know why they visited, but we can see that regardless of the war raging around the Moravian Native American village, the Moravians were still maintaining the level of interactions they had prior to the war with both friendly and foreign Native Americans. This entry also indicated the recurring question that many missionaries faced; how to keep Native Americans from excessive drinking. Once again, he did not provide any answer to this question, but the act of writing it indicates that it was a problem that he felt needed a solution.

Not only were outside Native Americans visiting the village, but, as was also the case in Meniolagomekah and Gnadenhütten, Native Americans living in the village continued to leave

${ }^{10}$ MAB, MissInd 1.20.125.2.5.

${ }^{11}$ MAB, MissInd 1.20.125.2.5, April 7, 1760. "Es kam nachmittags win gantzer [Schwane?] fremde Indianer hier an. Etliche war besoffen. qu. Wie ist der Sache zu rathen?" 
the village to visit their friends and family. Spangenberg wrote on April 9, 1760 that Lydia's friends invited her to the Susquehanna valley. Here Spangenberg asked: "is there a plan with the uncertainty of wars?"12 This question was obviously necessary during the violence of the period, but the underlying concern seemed not to be for the European Moravians, but rather, for Lydia and other converts who were leaving the safety of the village for the turmoil of the frontier. This concern was valid. The violence of the frontier had spread to where there were vigilante groups who would threaten Native Americans who travelled throughout the Indian paths and roads of Pennsylvania. The general distrust of the era, combined with the increased racial divide, left many people, whether European or Native American fearful to travel paths that they had once considered safe.

\section{Suspicion and Imminent Violence}

The general distrust of Native Americans in Pennsylvania continued with the creation of the new village of Nain. The distrust between European settlers and Native Americans was bound to affect the Moravian converts. The creation of the village at Nain did little to waylay the suspicions of European settlers and much to support them. This suspicion was not new. In fact, the city of Bethlehem was aware that there were rumors of the community in Gnadenhütten and connections with French allied Indians as early as $1755 .{ }^{13}$ The movement of Gideon and other

\footnotetext{
${ }^{12}$ MAB, MissInd 1.20.125.2.5, April 9, 1760. „Lydia wird von ihren freunden nach der Susquehanna invitirt. qu. Hat auch das eine absicht auf neue Krieges u unruhen?“

${ }^{13}$ Levering, 299.
} 
high-ranking Native Americans from Gnadenhütten to Wyoming, and their continued contact with the village, seemed to prove to suspicious European settlers that the Moravian Indians, and by extension European Moravians, were not trustworthy. The attack on Gnadenhütten in 1755, however, cleared suspicions away from the European Moravians in the eyes of many European settlers. ${ }^{14}$ This does not mean, however, that the feeling of misplaced suspicion continued into the following decade. The continued interaction with non-Christian or outside Native Americans fanned the earlier suspicions that white settlers had against the local Native Americans and the Moravian Native Americans. There was no promise that the local or Moravian Indians were not talking with and/or aiding French-allied Indians.

Regardless of white settlers' fears, interactions between Native American groups did not seem to abate, and the Moravians continued to welcome foreign Native Americans into the village of Nain. The open interactions must have also led to the interactions (primary, secondary, and tertiary) with French-allied Native Americans.

The diaries recorded evidence of some form of interaction with French-allied Native Americans on May 3, 1760.

A white man came to us, the father of the girl who old Moses the Indian brought two days ago, and he told us that she had been with the Indians for two years, was taken when he was buying things at Menissing. When he saw her, he wept and

\footnotetext{
${ }^{14}$ Levering, 314.
} 
wanted to greet and kiss her, but she would not go to him, and the father could not do anything without an interpreter. ${ }^{15}$

There was no indication as to who the girl or her father were, where the girl came from, who she had been with, or what happened to her after her father left Nain. Yet, the fact that the family reunion took place in the indicated that they had contact with the Native Americans who had taken her two years prior. Old Moses could have been Moses Tatamy, the man whose affidavit the Pennsylvania Gazette published after the attack on Gnadenhütten. His arrival from Wyoming to return a young captured girl to her father indicates that he had connections to those who captured her. We do not know how Moses was able to get the girl. He may have come across her innocently and decided to return her to her relatives. He may have made some negotiations with the people who captured her, making unknown promises for her release. There is no way to know how and why he brought her back, but the fact that she was not prepared or effusive at seeing her father showed the connection that this young girl made with the family and people that had taken her in.

This reunion showed that Moravians and converted Moravian Indians had connections to French-allied Indians. The Indians along the Susquehanna were the same groups and villages that European settlers suspected of the Gnadenhütten attack; they were the ones who tried to work the

${ }^{15}$ MAB, MissInd 1.20.125.2.4, May 3, 1760. Kam ein weisser mann zu uns, der Vater des Mädgens, welches der alte Moses der Ind schon vor eblich 2 tage mit hieher gebraucht, und wie er sagt, vor 2 jahren von dem Indianer, der es bei Menissing vor 5th halb Jarhe gefange weg geführt gekauft hat. Als der Vater sein Kind sahe, weinte er überlaut und wolte es grüsse und küsse, da es wolte aber durch uns nicht zu ihm gehen, und der Vater konte nicht anders als durch eine [delmertsh] mit der Kinde rede. 
Iroquois, the English, and the French against each other to maintain their independence in the area. It is no surprise that the Moravians and their Native American converts would continue to interact and visit with these groups. The men and women in the Indian villages on the Susquehanna were kin to the Native Americans who lived with the Moravians. They were friends and family, and there is little doubt that their relationships continued in some capacity after the war began.

Yet it was these continued interactions that made the European settlers uncomfortable. The possibility that their peaceful Native American neighbors were sharing information with enemy Indians gave many settlers ammunition against the Moravian Indians. This fear combined with the fear of attacks, both preemptive and retaliatory. Pontiac's War in the West cause similar episodes of raids and attacks on European settlers in the East. These attacks, in turn, led to more fear and apprehension toward innocent Indians. Vigilante groups, mostly Scots-Irish men from Paxtang, exploited these fears. ${ }^{16}$

\section{Pennsylvania Politics and the Moravians}

The French and Indian War lasted nine years on the North American continent. These years were fraught with raids and attacks on the frontier. During these years (1754-1763) the Moravian missionaries and their Native American converts merged two villages, saw a village

\footnotetext{
16 These men were known locally as the Paxton Boys. They had already come under scrutiny of the Pennsylvania Government as early as 1755, when retaliatory killings began on the frontier between the Paxton Boys and Native Americans. They were mostly made up of Scots-Irish Presbyterians who lived in Paxtang. They were the worst offenders of vigilante actions against the Moravian Indians and other Native American groups and their terrorism led to dozens of Indian deaths. Chapter 5 will explore this in depth. MPCP, 6:763.
} 
destroyed, pushed from their traditional lands, made refugees in Bethlehem, created a new village, and faced continuous threats from settlers. With the end of the war the violence remained, and the Moravian Indians went to Philadelphia for protection.

European kings signed the Treaty of Paris in 1763, which saw the removal of French imperial presence from North America. Ideally, this could have been the return to Penn's Great Peace in Pennsylvania. With the French out of the power struggle, the English, the Iroquois, and the smaller Native American tribes could have attempted to live and work alongside one another. However, during the war racial lines had solidified. Where once European settlers were aware of the differences in politics and culture between American Indian tribes, now most settlers, especially newer immigrants, lumped all the Native Americans together-as enemies and savages. Native Americans were also defining Europeans by harsher terms; they were the people who had stolen Native American land and had disrupted their traditional way of life.

During the war the Iroquois Confederacy did not act like a monolithic political forcesome members of the Confederacy chose to work with the French while others allied with the British. The English did not accept or understand the reality of Iroquois politics. This indicated to the English that Native Americans were untrustworthy. The European feeling of betrayal toward the Native Americans endangered the Moravian Native Americans who were still living in the contested frontier of eastern Pennsylvania.

\section{Political Background}

\section{End of the War}

In 1763 King George III and the Kings of France and Spain (Louis XV and Charles III) signed the Treaty of Paris. Peace negotiations did not consult the Native Americans in the 
frontier, which led to the Europeans divvying up the continent of North America without the input of any Native American allies. ${ }^{17}$ The European decision to ignore their allies caused more trouble on the American continent. The Native Americans, in response to this slight, began to see increasingly strong divisions between themselves and European Americans. ${ }^{18}$

\section{Eastern Pennsylvania}

While the western frontier was erupting into violence, the East was facing similar issues of violence and turmoil. Groups of settlers and Native Americans continued to contest the frontier lands. The problems that existed in eastern Pennsylvania before the war did not disappear by the end of the war. The question of land, especially, remained a contentious subject.

One of the redeeming factors of Pennsylvania was that the colonists were supposed to pay the indigenous inhabitants for the land they lived on and used. ${ }^{19}$ After the war the English colonists felt that it was their right to move into the frontier because the English defeated the French and had been living in relative peace with the Native Americans for nearly a decade. In June 1763, the Provincial Minutes reported that English subjects were moving into Native American land that they had not purchased from the Delaware. The Governor, having heard the reports of unlawful squatting on Native American land, issued a proclamation, "strictly enjoining

${ }^{17}$ Colin G Calloway, The Scratch of a Pen: 1763 and the Transformation of North America (Oxford, England; New York: Oxford University Press, 2006), 66.

${ }^{18}$ Calloway, 16.

${ }^{19}$ We know, however, that while Penn may have begun this tradition, others were more willing to steal and take land from the indigenous inhabitants without proper purchase. 
\& requiring in His Majesty's Name all and every person and persons already settled and residing on the said Lands (Indians excepted) immediately to depart and move away from the same." 20

Hamilton not only engaged the people of Pennsylvania in the Governor's proclamation, but any non-Indian. While this may seem like a small point to notice, it is interesting because there were settlers from Connecticut also claiming land in the Wyoming Valley. ${ }^{21}$ Unsurprisingly, the proclamation of the Governor did little to stop the tide of settlers into the land. Perhaps the English expected the Native Americans to move farther west-into the land recently abandoned by the French. However, other indigenous peoples already populated the West, and the French had never controlled it completely.

With English settlers moving into the fertile land of frontier Pennsylvania, it is not surprising that the Native Americans there were going to react violently to this incursion. Even before the Walking Purchase of 1737 the English continuously moved into traditionally native lands, without paying for the rights to their use, and expected the Native Americans to act peacefully. Many tribes, especially those who had questionable loyalty and increased tension with the English, like the Delaware and the Shawnee, did not back down from the continued aggression of English settlers. This hostility placed the Moravians and their Native American converts in a precarious position. On the frontier they did not fully belong to either group, European or Native American. The German Moravians, based on their dedication to their language, their culture, and their sustained interactions with Indians were ethnic outsiders from

${ }^{20}$ MPCP, 9:27.

${ }^{21}$ MPCP, 9:6. 
the English and other white settlers, but were still Europeans to the Native Americans. The Christian Indians, similarly, were religious outsiders who allied themselves with Europeans, probably to the detriment of Native American relationships. To other Europeans the Indian identity was more important than their identity as Christian. Both primary groups within the Gnadenhütten community were marginalized outside of the village, which necessitated continued cooperation among the community.

\section{Petition for Protection}

Petitioning the Government

The continued tensions between the Moravian Native Americans and European neighbors remained evident in the letters that Moravians, including Schmick and Grube, exchanged with Hamilton in 1763. In July, Schmick and Grube (the primary missionary in neighboring Wechquetank) acted as witnesses to a letter sent to Hamilton by the Native Americans of the villages of Nain and Wechquetank. In this letter, the Christian Indians requested that the Governor ensure that that settlers who lived near the villages let the Native Americans live and hunt in peace. The Christian Indians were targets to both warring Native American polities and settlers. The Moravian Indians acknowledged in their letter to Hamilton that some Indians (not

from their groups) had not given up the war, but they argued that as Christian Indians they would be as much a target to renegade Indians as their European neighbors. ${ }^{22}$ The Moravians already

\footnotetext{
${ }^{22}$ MAB, MissInd 1.34.124.7.1.
} 
faced the Indian attack on the village of Gnadenhütten in 1754, but the attackers failed to kill any Indian congregants. The continued violence between the settlers and Native Americans placed the Christian Indians in a perilous position: one where they did not belong to either group. The 1755 attack on Gnadenhütten justified the Indian congregants' fears, thus prompting the letter to the Governor.

On August 3, 1763, Hamilton responded. He assured the Moravian Indians that if they remained friendly to the English colonists he would order the officers and anyone in his command to leave them alone. He also suggested that the Moravian Indians wear a badge of friendship to distinguish them as friendly Indians to the colonists. The Governor also decided to send a certain amount of powder and lead, in order to help the Indians on their hunts. ${ }^{23}$ Hamilton's response showed that while he was aware of their problem, he also thought that instead of fully punishing the vigilantes who were causing the anxiety of the Moravian Indians, he wanted the Indians to alter their way of life. The implication was that the Native Americans would have to somehow show the settlers that they were not a threat, rather than the settlers waiting for signs of violence from the Native Americans. This was a type of victim blaming that showed that Hamilton, even if implicitly, regarded the Native Americans as being responsible for their treatment by the settlers. The parameters that Hamilton placed on his aid proved this, “...that as long as they behave unoffensively, and in a friendly Manner to the Inhabitants, they may be assured of all the Protection..."24

${ }^{23}$ MAB, MissInd 1.34.124.7.3.

${ }^{24}$ MAB, MissInd 1.34.124.7.3 
The governor told the officers that if the Native Americans are acting peacefully they should remain unmolested. Yet, it was not the Moravians who were causing the anxiety. The threats were coming from the European settlers, who were not acting "peaceably and in an orderly manner". ${ }^{25}$ The European settlers did not have to bear the brunt of the changes. Native Americans' bore full responsibility.

Regardless of the injustice of the situation, the Moravians and their congregations wasted no time. They began planning ways to distinguish the friendly, Moravian Indians, from hostile Indians. Their plan "for protecting \& supporting the Christian Indians at Nain near Bethlehem \& at Nazareth, \& to ease the Inhabitants of that County from their Apprehensions and Fear" was fourfold. ${ }^{26}$ First, they limited the area of the Indians to the lands of Bethlehem and Nazareth to ensure their protection. Next, two Muster Masters, chosen European men "whom the Inhabitants of that County are supposed to have Confidence" would check the Indians daily, making sure that they were present. ${ }^{27}$ Third, each Indian present at the mustering would be given a daily allowance. Last, the Muster Masters would keep the County Clerk, who in turn kept the Governor, informed of the Indians, their attendance, and their actions. ${ }^{28}$ Unfortunately, this plan was more controlling than helpful.

The Moravians created this plan for one hundred and thirteen Indians at Bethlehem and Nazareth, and the Moravians and Government allotted funds for that number of people. The

\footnotetext{
${ }^{25}$ MAB, MissInd 1.34.124.7.3

${ }^{26}$ MAB, MissInd 1.34.124.7.5.

${ }^{27}$ MAB, MissInd 1.34.124.7.5.

${ }^{28}$ MAB, MissInd 1.34.124.7.5.
} 
amount they proportioned, however, showed a distinct bias toward the Muster Masters. The government gave each Muster Master five crowns and six shillings a day, while each Native American would receive three pence. This indicated that the Moravians and the Governor only agreed to protect the one hundred and thirteen American Indians that had already moved to Bethlehem and Nazareth, in effect pausing the missionary work of the Moravians.

By placing a specific limit on the number of Indians and the amount of money allotted, the plan limited the number of Indians the Moravians could bring into the community with the promise of protection and aid. It also showed that the government was aware that this protection went against American Indian tradition, because the Native Americans lost their freedom of movement. The plan forced Indians seeking protection to remain in the areas of Bethlehem and Nazareth. The government gave daily funds for the Indians to survive in a world where they had few, if any, practical skills. Traditionally, the Christian Indians lived off their hunting skills, going out on hunts regularly. The stationary nature of this plan meant that most of the Indians (especially the men) would no longer be independently productive and, therefore, they needed recompense for that.

Even after the move from the villages of Nain and Wechquetank, the threat of the settlers to the Moravian Indians continued. It was so great by October 10, 1763, that Bethlehem citizens sent a letter to Hamilton, which noted that the suspicions of the local settlers against the Moravian Indians was not new. This letter, written by Peter Boehler, a Bishop in Bethlehem, recalled that the local settler population had suspicions concerning the Native Americans even prior to the attack on the village of Gnadenhütten. He wrote that in 1755 , “... some prejudiced 
men spread a false report...” about the Moravian Indians supporting “...the cruel and barbarous invasion of the Savages.",29

This letter proved that the misgiving of the local European population did not begin suddenly in the 1760s. Additionally, Boehler wrote that because of the deadly attack on the village, "God did clear us from that false imputation by permitting that heavy stroke to fall upon our People, then living at Mahony..."30 This indicated that Boehler recognized that the attack on the village in 1755 eased the suspicions of the prejudiced European settlers. It is important to remember that the attack left eleven Moravians dead. ${ }^{31}$

In the letter to the governor, Boehler also noted the continued threat of Native American violence against the Moravian Indians. "Notwithstanding the threatenings from their Nation of whom they are even now in fear as well as out white fellow subjects..."32 Here, Boehler acknowledged the continued fear and threat of violence against the pacifistic Moravian Indians from members of their own traditional groups. This fear, however, did not prevent their continued interactions with the people of the Native American villages in hopes of continued missionary work and conversions. The European Moravians' primary goal was the continued

29 “1763 Letter from Peter Boehler to Governor James Hamilton,” Bethlehem Digital History Project, accessed June 20, 2018, http://bdhp.moravian.edu/personal_papers/letters/indians/1763boehler.html.

30 "1763 Letter from Peter Boehler to Governor James Hamilton."

${ }^{31}$ As was noted in chapter 3, it is probable that the Moravian Indians believed that by removing themselves from the village they would spare the village the violence that had been threatened upon it. This theory seems to stand up to scrutiny based on the suspicions of Boehler. If the Moravians and their European neighbors doubted the sincerity of the Moravian Indian motives to leave the village prior to the deadly attack, the attack itself would not have appeased the suspicions of neighboring settlers, and could have raised the suspicions of the German Moravians.

${ }^{32} \mathrm{MAB}$, MissInd 1.26.127.5.1. Petrus Boehler, petition to Governor James Hamilton, October 10, 1763. 
conversion of Native Americans, which they could only accomplish through greater interaction with unbaptized American Indians. The Moravian Indians, however, continued with their interactions on a more familiar level--one of kinship and family. This does not, however, mean that the Indians did not experience anxiety or fear with these interactions.

Boehler was also worried that any attack on the peaceful Moravian Native Americans would cause an uprising — not only among the American Indians who were affiliated with the Moravians, but also among Native Americans who would seek a racial revenge upon the white settlers. He wrote of his fears that any attack on the pacifist Indians “... would not only bring a Blood Guilt upon our County..." that the "Savages" "... might come down in such numbers..." that the colony would not be able to defend itself. ${ }^{33}$ This warning showed the possibility of further violence and vengeance on the frontier after the technical end of the war. Boehler recognized the Indians of the Moravian villages as guiltless but also cautioned that their pacifism may not remain if the European vigilante group attacked, which, combined with the use of the word "savages" to address other Native Americans seems to indicate that Boehler did not consider pacifism a natural state to the Indians.

The threats of the vigilante group were not merely theoretical. In fact, according to Boehler, settlers threatened the Moravian Indians “...with fire \& sword...” while they moved to the village of Nazareth "...to the great Detriment in their lively hood..."34 This move, coupled with the lack of provisions and livelihood, put the Moravian Indians in a compromised position.

${ }^{33}$ MAB, MissInd 1.26.127.5.1. Petrus Boehler, petition to Governor James Hamilton, October 10, 1763.

${ }^{34} \mathrm{MAB}$, MissInd 1.26.127.5.1. Petrus Boehler, petition to Governor James Hamilton, October 10, 1763. 
Once again, the government forced them from their traditional land, removed from their traditional way of life, and expected them to adapt to the changes with little help from those who pushed them. Additionally, as Boehler noted, the white vigilantes were aggressive and threatened the Moravian Indians. The pacifistic beliefs of the Moravian Indians made them an easy target for the vigilantes. Instead of the vigilante group approaching and questioning a war party, they were threatening peaceful Indians-including women and children—who were on their way to what they considered a safer location.

These vigilantes were acting in retaliation against attacks on farms and settlers. The Pennsylvania Gazette printed several accounts of Native American attacks on white settlers on October $13,1763 .{ }^{35}$ These accounts were from the week prior and told of several unnamed Native Americans from unknown tribes who shot at and killed European settlers. These reports helped fuel the animosity between the white frontier settlers and the Native Americans, which, once again, put the Moravian Indians in a difficult position. Settlers accosted them due to being Native American, but other Native Americans also singled them out due to their continued connection with the Moravians.

One of the newspaper reports showed that people were fleeing the frontier and were looking to Bethlehem and Nazareth for protection. This protection extended, of course, to the

${ }^{35}$ Accessible Archives, The Pennsylvania Gazette (Philadelphia, Pa: B. Franklin and H. Meredith, 1729), October 13, 1763. 
converted Native Americans. Yet, vigilante groups like the Paxton Boys and other frontier settlers, continued to suspect the Moravian Indians as conspirators.

Not all the frontier people saw the Moravian Native Americans as traitors, though. In fact, in October 1763, settlers in Lower Smithfield township wrote a letter to the governor in which they asked the Governor “...if it could be that Your Honor may Advise or Direct them to live in our Neighborhood again..." ${ }^{36}$ Unlike the Paxton Boys, the settlers in Lower Smithfield township recognized that the Moravian Indians were peaceful and they also realized that they could play an important role in their mutual protection. "For certainly, they are first more capable of Detecting Evil Indians than White People...". 37

This letter proved that while there was frontier support for the actions of the Paxton Boys, not all the settlers were afraid or suspicious of the Moravian Native Americans. In fact, these inhabitants asked the Governor to tell the Moravian Indians to return to living as their neighbors. They recognized how important the Moravian Native Americans could be in their protection. They must have had significant amount of trust for the Indians to ask the Governor to send them back to the township. They also believed that the Moravian Indians were being truthful-- "...as We have no Doubt of their Veracity..." -- in their denial of any collusion. ${ }^{38}$

Despite the requests of the inhabitants of Lower Smithfield township, the plan to protect the Moravian Indians from white vigilante groups by keeping them on the land around Nazareth

${ }^{36}$ MAB, MissInd 1.34.124.7.5.

${ }^{37}$ MAB, MissInd 1.34.124.7.5.

${ }^{38}$ MAB, MissInd 1.34.124.7.5. 
and Bethlehem was in place until Governor James Penn replaced Hamilton. The King assigned Penn Governor in a move to return the colony to his family's governance. With the arrival of Penn, the plan changed dramatically. Schmick noted this dramatic shift in a letter sent to Penn dated November 9, 1763. Instead of moving the Moravian Indians into Bethlehem and Nazareth Penn decided to move them to Philadelphia. On the back of a letter describing Hamilton's plan someone wrote: “...J. Penn... responded that the Indians should be brought down to Philadelphia \& so this scheme he [Hamilton] approved of was laid aside."39

The Moravian Indians faced similar limitations of movement and self-sufficiency with this new plan. However, while the initial plan created with Hamilton allowed them aid on land where they had relative freedom (albeit limited mobility) the plan created by Penn effectively made them prisoners within Philadelphia.

\section{Conclusion}

This chapter, through Moravian letters, Provincial Minutes, communal diaries, and newspaper accounts, showed that settlers threatened the Native Americans who had allied themselves with the Moravians just as much, if not more, after the Seven Years' War as they had prior to the war. The movement to the village of Nain, after the destruction of their prior village, saw both happiness - with the return of some of the congregation — and fear — with the continued threats of vigilante groups like the Paxton Boys. The Pennsylvania government did not have a

\footnotetext{
${ }^{39}$ MAB, MissInd 1.34.124.7.5.
} 
comprehensive plan to deal with either the threats to the English settlers or the threats to the Native Americans. At first Hamilton tried to send the military to help the European settlers in the West, while simultaneously attempting to remove white settlers from Delaware land in the eastern frontier. The king's Proclamation Line only helped to muddy the efforts further. When the Moravian Indians and missionaries asked for aid, the government at first demanded model behavior from the Moravian Native Americans, as well as social and cultural concessions that would leave the Moravian Indians completely dependent on the government and the Moravian Church for their sustenance. Finally, the government, under the new leadership of Governor John Penn, decided to have the Moravian Indians come to Philadelphia. This allowed the government to not only protect the pacifistic Moravian Native Americans, but to also make it that the Moravian Indians were under the direct supervision of the government, thus making it difficult for them to betray their trust. 


\section{Imprisoned Community}

The previous chapter argued that the post-war period was more dangerous for the Moravian Indians than the years of the war, due in large part to the growing suspicions and divide between frontier settlers and Native Americans. The movement of the Moravian Indians from the Pennsylvania frontier to Philadelphia created several problems for the Native Americans, the European Moravians, and the Philadelphia citizenry. The threats of violence that plagued the Moravians in the frontier caused the Pennsylvania government to act paternalistically, removing the Native American converts from the situation. In this chapter I argue that Pennsylvanian politics created a situation where the Moravian Indians were unable to leave the security of Philadelphia, despite that fact that both the Pennsylvanian government and the Moravian Indians wanted the congregation removed from Philadelphia. Regardless of the desires of these groups, after a failed attempt at relocating the Moravians, the Governor and the Assembly decided that the threat to the Indians was too great, in large part due to the political tensions that they created. The decision to keep the Moravian Indians in Philadelphia caused tensions in both the colony and the congregation, as many did not trust the Native Americans and acted out of fear. The tense relationship between the Governor and the Assembly added to political tensions within the city, which created further problems for the Indians. Where once the Moravian congregation shared culture, experiences, and goals, now many of them had disparate goals, which led to strife in the community.

The decision to move the Moravians from the frontier to Philadelphia removed the Moravian Indians from their traditional way of life and forced them to rely on the Philadelphia citizenry. The citizens of Philadelphia and eastern Pennsylvania were not pleased with the 
relocation. Suspicions fueled the growing racial animosity during the war and created outraged citizens who were furious that Governor brought unruly and untrustworthy Indians into the city. To soothe the increasing frustrations, Penn decided to move the Moravian Indians to New York, which caused them to temporarily leave the colony. Subsequently, though, they were pushed back into barracks in Philadelphia, where the close quarters led to several bouts of deadly illnesses, rising frustration, and community tensions.

This chapter uses Provincial Minutes, mission diaries, and Moravian letters to show that the Pennsylvania government and most of the Moravian Indian community were after the same goal - to get the Indians back into the frontier as safely as possible. The longer the government held the Moravian Indians in Philadelphia, the stronger the tension in the community became, endangering the cohesion of the multi-ethnic community. First, this chapter will look at the Moravians' move to Philadelphia, the initial decision of Penn to forgo Hamilton's plan of aiding the Indians in the frontier, and instead bring the Native Americans to Province Island, five miles south of the city center. It will also examine the backlash of the citizens of the city and the tensions between the Governor and the Assembly. Then it will explore how Penn tried to placate both the citizens of the city and the Moravian Indians with a plan that sought to remove the Moravians and their Native American converts from the colony to live with kin in New York, along the northern branches of the Susquehanna. Next it will explore the Moravian Indians and their desire to leave the barracks. While many within the congregation were grateful for the safety that the government provided, many others were frustrated with a lack of freedom and the neglect of a government that had promised to care for them during their internment.

\section{Movement to Philadelphia}


Due to the continued threats by primarily Scots-Irish vigilante groups, Penn decided to remove the Moravian Indians from the frontier. These orders came in late October 1763 and by early November 1763 the Moravian congregations of Nain and Wechquetank, along with twentytwo Indians from Wyalusing, arrived in Philadelphia. There were over one hundred forty Native Americans who entered the city in total. ${ }^{40}$ The government had to decide where to house the Native Americans, and chose Province Island, directly outside of the city on the Schuylkill River, as the best place to monitor and aid the Moravians. This island was approximately three hundred acres and was the location of the city's quarantine house. ${ }^{41}$ Prior to the Moravians, other displaced Native Americans, whom Grube called neutrals, lived on the island.$^{42}$ The Moravian refugees entered the city on November 9, 1763. On November 12, 1763 Brother Grube sent a letter to the Moravian leaders in Bethlehem to let them know that the refugees from Nain and Wechquetank had arrived in Philadelphia. In the letter, Grube wrote of the tension among the people in the city at the arrival of the Native Americans: "The fury of the people in Philadelphia

40 There is some dissent on exactly how many Indians came. Some sources do not give precise numbers. Scott Paul Gordon, "The Paxton Boys and the Moravians: Terror and Faith in the Pennsylvania Backcountry", Journal of Moravian History, 14, no. 2 (2014). Gordon said there were 143 Indians total, 22 from Wyalusing and 121 from the missions. Kevin Kenny, Peaceable Kingdom Lost: The Paxton Boys and the Destruction of William Penn's Holy Experiment (Oxford University Press, 2009), wrote that there were 127 Indians from the missions, and the 22 Indians from Wyalusing who arrived in the city on November 30, 1763.

${ }^{41}$ Kevin Kenny, Peaceable Kingdom Lost: The Paxton Boys and the Destruction of William Penn's Holy Experiment (Oxford University Press, 2009), 145.

42 "Bethlehem Diary, November 16, 1763," Bethlehem Pennsylvania Moravian Indian Diaries at the Bethlehem Digital History Project, accessed April 22, 2018, http://bdhp.moravian.edu/community records/bethlehem diary/16nov1763.html. There is no indication as to what tribes/peoples the neutrals belonged. 
was indescribable, and we had to stand in front of the barracks for fully three hours and take all kinds of disgrace and scorn." 43

While the Moravians may have initially been pleased with the area of Province Island, which Grube described as "pretty and comfortable"; the size of the buildings and rooms, "spacious rooms with fireplaces"; and the man who was to supervise their stay, Mr. Joseph Fox, “...a nice man and will be very helpful to us...", their treatment by the citizenry of Philadelphia was a precursor of the treatment they would continue to receive by the government and the English people. ${ }^{44}$ The aggression of the mob-and the neglect of those who made them wait before they could continue onto the island - showed how little the city cared for the well-being of the Native Americans.

Moravians sent the first letter concerning poor treatment of the interred Native Americans to the Governor on November 14, 1763, only a few days after the arrival of the group to the city. 45 This petition, written by Schmick in English and coupled with the information from the letter Grube sent to Bethlehem, revealed much about the situation on the island. First, naming the "unruly Behaviour of the City Mob" proved that the citizenry of Philadelphia did not universally approve or accept the decision to bring the Moravian Indians down for protection. The city itself was at odds. Many people who lived within the city were people who were displaced due to the

\footnotetext{
43 "Bethlehem Diary, November 16, 1763." Here is Grube's description of the mob: "Die With der Leute in Philadelphia war unbeschreiblich und wir musten se wohl bei 3 Stunden vor den Barracks stehen u. alle Schmach und Spott einnehmen. Durch die Stadt durch hatten wir viele 1000 zu Begleitung, doch gings ohne Schaden ab.” 44 "Bethlehem Diary, November 16, 1763."

${ }^{45}$ MAB, MissInd 1.26.127.5.4, John Jacob Schmick and Lewis Weiss, petition to Governor John Penn, November 14, 1763.
} 
war and the continued violence in the frontier. ${ }^{46}$ Others in the city were newer immigrants, mostly from Northern Ireland, who did not have the Quaker history of friendly Native relations. ${ }^{47}$ Instead, people within the city were willing to protest that the Moravian Native Americans had arrived and were under the protection and charity of the people. This caused additional tension, as did the lack of employment due to the end of the war boom, and increased population due to immigration and refugees, both of which led to an overall increase in poverty and charitable needs. ${ }^{48}$

The Moravian leaders indicated that the behavior of a mob caused the government to overlook Moravian Indian needs. The initial arrival of the Native Americans, their forced wait at the barracks, and the lack of provisions and necessities at Province Island show that the government was not prepared or organized for the Moravians, despite having ordered them to the city. Schmick wrote that the lack of provisions was due to the "remoteness" of the island, yet the government had known for a month that the Moravians would be arriving. ${ }^{49}$ While the Moravians were aware that the government would house them on Province Island, they were dependent on the charity of the city for their safety and sustenance. It is probable that those who protested the arrival of the Native Americans were upset about the requirement to provide for the well-being of the Moravian Indians. The rising population and number of impoverished people in

\footnotetext{
${ }^{46}$ Gary B. Nash, "Poverty and Poor Relief in Pre-Revolutionary Philadelphia," The William and Mary Quarterly, 33, no. 1 (1976), 12.

47 Nash, 12.

${ }^{48}$ Nash.

${ }^{49}$ MAB, MissInd 1.26.127.5.4, John Jacob Schmick and Lewis Weiss, petition to Governor John Penn, November 14, 1763.
} 
Philadelphia had already caused the poor tax to increase, along with the number of people who received charitable help. ${ }^{50}$ The Governor was likely aware that if he and the Assembly provided too much for the Native Americans under their protection, the local dissenters would protest more frequently and more loudly, causing increased friction in the city.

Given this dissent, it is probable that the Governor cared more about attempting to maintain a positive atmosphere in the city than about the well-being of the Native Americans under his protection. While there is little direct evidence to prove motive, given Schmick's petition, neglect was clear; the Moravians had only been in Philadelphia for a week, and already the Native Americans on the island were "...in immediate want of fire wood and Provisions...". ${ }^{51}$ If the Governor and the Assembly had taken the protection of the Moravian Indians seriously it seems that they would have prepared provisions and necessities for them on the island. Instead, the Moravian Indians were already living under harsh circumstances with the depths of Pennsylvania's winter still ahead of them.

The community diaries of Province Island do not begin until December 1, 1763, several weeks after their arrival. Yet, given the entry from December 4, it did not seem that the city had grown more accepting of the Moravian Native Americans: "We had a gathering in which many necessary things were mentioned, in particular going to the city and shopping, which we must

\footnotetext{
${ }^{50}$ Nash, fig. 1.

${ }^{51}$ MAB, MissInd 1.26.127.5.4, John Jacob Schmick and Lewis Weiss, petition to Governor John Penn, November 14, 1763.
} 
suspend entirely for the time being because the people are angry again." 52 Despite being under protection, the Moravians were still worried about their safety in the city — and specifically from citizens. Their well-being and routine demanded that they make the five-mile trip from the island to the city proper for the supplies that they needed. Despite the lack of supplies, from the communal diaries it seemed that governmental protection eased the anxiety of the Native Americans. The same day that the Moravians decided it would be too much of a risk to go into the city for provisions, Grube wrote that the Native Americans declared their relief, "...we are happy that we can sleep peacefully again and eat our bread without fear." 53 It seems ironic that on the same day Schmick chose not to travel into the hostile city for their supplies and provisions, the Native Americans claimed that they felt safe and able to live "without fear". Of course, the European Moravians who wrote the entries relayed the state of the Native Americans to the reader of the diaries second-hand. It could be that Schmick was exaggerating how safe the Native Americans felt to make the move to Philadelphia seem successful for the congregation. Remember, Moravian missions shared diaries to unify congregations in goals and culture. If the congregation remained fearful, it could reflect poorly on the decision of the Church to accept

52 "Bethlehem Digital History Project, Province Island Diary Source 1," Bethlehem Pennsylvania Moravian Indian Diaries at the Bethlehem Digital History Project, accessed April 20, 2018, http://bdhp.moravian.edu/community_records/christianindians/provincediary/provincesource1.html.

${ }^{53}$ Katherine Carte Engel, "Bethlehem Digital History Project, Province Island 1764," Bethlehem Pennsylvania Moravian Indian Diaries at the Bethlehem Digital History Project, December 4, 1763, accessed April 20, 2018, http://bdhp.moravian.edu/community_records/christianindians/provincediary/1764province.html. Katherine Carte Engel translated the digital sources. I have checked each entry that I used to ensure that I agree with the translations. This particular section in the source has no signifier as to who wrote it. The handwriting of the diary, however, resembles Schmick's hand. While most of the diaries were written by Schmick, many of them, including ones written by him, refer to all of the Brothers in the third person. Even if we know that Schmick wrote the diary he would write that Brother Schmick went to visit, more often than he would write I went to visit. 
Penn's protection. It could be that the Native Americans were not sharing their anxiety about the new community with the Moravians. Those who spoke with Grube and his wife claimed to feel safer in the city - but that does not mean that all the Moravian Indians felt safe. It could also be that even with the turmoil of the city, the Native Americans were more worried about the uncertainty of their lives on the frontier. At least when living near the city, the government underscored their protection.

On December 14, 1763, the Paxton Boys' threats culminated in an attack on peaceful Native Americans who lived south of Paxton, which validated the fear the Moravians had on behalf of their Native American converts. ${ }^{54}$ The Paxton Boys attacked and murdered six members of the Conestoga tribe. Colony magistrates took the survivors into custody and placed them in a workhouse in Lancaster, under citizen guard. ${ }^{55}$ The deaths of the Conestogas confirmed the fears of the Moravian Indians and proved to the Pennsylvania government that the frontier settlers were out of control. On December 22, 1763, Penn wrote a proclamation concerning the Moravian Indians, in response to the attack and murder of the Conestoga Indians by the Paxton Boys. He noted in the proclamation that the government already brought friendly Indians, those from Wyalusing and the Moravian Indians, to Philadelphia for their protection: “...Where Provision is made for them at the Publick Expence [sic]. I do therefore hereby strictly

\footnotetext{
${ }^{54}$ Griffin, 46-47.

${ }^{55}$ Griffin, 47.
} 
forbid all Persons whatsoever, to molest or injure any of the said Indians, as they will answer the Contrary at their Peril." 56

With this proclamation we can assume that the government was taking the protection of the Moravian Indians seriously. However, the Governor ignored the history of the Moravian's requests, suggesting the congregation asked for removal from the countryside, rather than their actual request for aid on the frontier. Beginning in July of 1763, Moravian correspondence with Hamilton spoke of their desire to remain in their villages, seeking assurances that the government would punish settlers if they attacked the Moravian Indians. It was not until Penn replaced Hamilton that the Governor decided to remove the Moravian Indians, and others, from the frontier. It is possible that the proclamation fueled the anger of the offending settlers, vigilante groups, and those who supported them. While the government professed their commitment to the "ancient Friendship" of the Native Americans, they also admitted to the people that the Native Americans, while under their protection, were being cared for "at the Publick Expence [sic]." ${ }^{57}$ It is probable that those who were angry at the freedom and perceived betrayal of the frontier Native Americans would be upset that not only were they being physically protected by the government, but that they were receiving governmental financial aid as well. This seems especially probable given the increase in the poor tax in the years directly following the Seven Years' War.

\footnotetext{
56 MPCP, 9:96.

${ }^{57}$ MPCP, 9:96.
} 
Not only did the Governor admit that the people were funding the Moravian Indians' subsistence, he also reported where the Native Americans were being held: Province Island. This gave those with grievances, like the Paxton Boys, a specific place to focus their anger. The removal of the Native Americans, either the Conestogas to Lancaster or the Moravians to Philadelphia, did little to quench the terrorism of the Paxton Boys. The anger and threats continued, and on December 27, 1763, five days after Penn published his proclamation warning about future harm to the protected Native Americans, the Paxton Boys raided the warehouse in Lancaster and killed the remaining Conestogas. ${ }^{58}$

On December 29, 1763, the Governor held a council meeting in Philadelphia where the council read a letter from Edward Shippen, dated two days previous. This letter described the attack on the Conestogas in Lancaster and warned the Governor and his council of more planned attacks. Several relevant pieces of information are contained in this letter. First, the rioters were unafraid to do their murdering in broad daylight, as the attack was "between two and three o'clock this afternoon." 59 The fact that "upwards of a hundred armed men" were able to coordinate an attack without any substantial backlash from the community could indicate that they had a certain level of support in the community. It could also indicate that those who were slated to protect the Conestogas were afraid or unable to stop the large vigilante group. Second, this letter also proved that the Paxton Boys were well organized; they knew exactly where the Conestogas were hiding, where to put their horses, and quickly killed the remaining Native

${ }^{58}$ Griffin, 47.

${ }^{59}$ MPCP, 9:100. 
Americans before leaving. While the Sherriff, the Coroner, and others tried to stop their exit, there did not seem to be a comparable group that was willing to step between the rioters and the Native Americans. The rioters, given the time of day, seem to have felt justified in their attack; they did not try to hide their intentions, nor try to hide their identities. There was no mention of disguises or any other types of costume that would stop others recognizing them. They were also aware of the location of other peaceful Indians, as the letter warned, "some people say they heard them declare they would proceed to the Province Island, and destroy the Indians there." ${ }^{60}$ The governor announced where the Moravian Indians were being held just a few days before the raid, thus it was not surprising that the raiders were able to locate them.

The Governor and the Assembly, two forces that rarely worked together, took several measures to try and apprehend the rioters, as well as protect the Moravian Indians. ${ }^{61}$ The Governor and his Council sent a return message to Shippen in which they asked him to attempt identification of the rioters and, more importantly, the leaders of the vigilante group. It was rumored that the rioters were men from Lancaster County. They also sent letters to leaders in the towns of Carlisle and Paxton asking for intelligence and to suppress any violence. ${ }^{62}$ Along with oversight of town and community leaders, the council and the governor offered a reward of two hundred pounds each for "apprehending \& securing the Ringleaders of the Rioters". ${ }^{63}$ These measures indicate that they were serious in apprehending the vigilantes, however, it does not

\footnotetext{
${ }^{60}$ MPCP, 9:100.

${ }^{61}$ Hindle, $467-68$.

${ }^{62}$ Hindle, 469.

${ }^{63}$ MPCP, 9:101.
} 
necessarily suggest that these actions were inspired solely by the violence against the Native Americans. It is more likely that the colonial government was interested in apprehending the vigilantes because they were circumventing the legal system and were acting without, and against, the authority of the Pennsylvania government.

The same day that the council read the letter from Shippen, The Pennsylvania Gazette published a report on the initial Conestoga attack and the resolve of the colonial government to find and try the vigilantes. The report included the initial proclamation from December 22, 1763 and also added that the Governor tasked all of the loyal people in the province to "make diligent Search and Enquiry after the Abetters and Accomplices" in order to bring the vigilantes "to their Trials, and be proceeded against according to Law."64

While the Governor may have sought to catch the rioters to chiefly to preserve the authority of the state, the government did not forget about the threat to the Native Americans on Province Island. At the council on December 29, 1763, the council decided to send aid to the Moravian Native Americans. Their situation on the island protected them from the outside threats, but it also possibly made them easier targets: if the vigilantes were able to cross the water the Moravians would not be able to retreat from the attack. With that in mind the Governor decided to send ships to provide protection and a means to retreat, if necessary. On December 29,1763 , the communal diary recorded that after the evening service word came that the Moravians needed to prepare to flee Province Island: "At midnight two boats came here...

\footnotetext{
${ }^{64}$ Accessible Archives, The Pennsylvania Gazette, December 29, 1763.
} 
indicating that we should be brought away from here quickly... on account of the Irish Rebels who have come down from Lancaster County in order to kill us." ${ }^{65}$ That night and the following morning the Moravians prepared to leave. The diary noted that the "boat people" kept watch while they prepared, and guards kept watch that during those nocturnal preparations. The next day (December 31,1763) the Moravians received a letter from Fox, stating that it was time for them to flee, as the government relayed word that the rioters were twelve miles away and in considerable number. The Moravians immediately boarded the ships and fled to Leek Island. Later in the day another letter arrived from the Governor addressed to Schmick and Grube. It explained that the reports of the Paxton Boys' encroachment were false, and that the Moravians needed to return to the island, where soldiers would protect them. ${ }^{66}$

The council met that same day and decided to muster fifty men to go to the barracks and protect the Moravian Indians from threats of violence against them. While the Provincial Minutes reported that fifty men would be sent, and the communal diaries recorded that men would be sent for protection, there is no record of when the guards arrived ${ }^{67}$ However, on January 1, 1764, Fox himself arrived and let the Moravian congregation know that the ships would remain at the island, where they would be useful if the vigilante group decided to descend upon the island. ${ }^{68}$ On January 2, 1764 the diary mentioned that the guards went into the city for

\footnotetext{
${ }^{65}$ Engel, "Bethlehem Digital History Project, Province Island 1764.” Mr. Fox, the man who sent the warning to the Moravians, was a lawyer who seemed to supervise the protection and provisioning of the Native Americans during their time in Philadelphia.

${ }^{66}$ Engel.

${ }^{67}$ MPCP, 9:101; "Bethlehem Digital History Project, Province Island Diary Source 1."

${ }^{68}$ Engel, "Bethlehem Digital History Project, Province Island 1764."
} 
provisions. So, we know that between December 31, 1763 and January 2, 1764 at least some of the fifty guards assigned by the Governor and the council arrived on the island.

The threat of the Paxton Boys was still present, and the guards, while providing some protection, could not withstand a substantial vigilante force. On January 3, 1764, the Governor and his council met to discuss the future of the Native Americans on Province Island. They read an anonymous letter, dated December 31, which warned that over two hundred men from Lebanon, Paxton, and Hanover Townships in Lancaster County were marching on Philadelphia in order to kill the Moravian Native Americans. ${ }^{69}$ Not only did this letter let the council and Governor know that these vigilantes were on the way, it even provided them information on vigilante group's supporters: “...\& That many of the Farmers near the Mountain had contributed largely to defray the Expences [sic] of such of them as were not able to procure Horses, and pay their charges, \&ca." 70 The farmers and settlers, who had essentially squatted on Native American land, were contributing to the campaign of the Paxton Boys. The anonymous letter allowed government to recognize that their own settlers were working alongside the vigilantes rather than following the proclamation of the Governor. The settlers who lived away from the cities — or even, given the discontent in Philadelphia, within the city- did not support the protection of the Native Americans at Province Island.

${ }^{69}$ MPCP, 9:108.

${ }^{70}$ MPCP, 9:108. There is no indication as to which mountain they mean, but as these townships all lie on the plains of Lancaster County, east of Philadelphia, it could mean Cornell Peak, the highest elevation for that county, or it could mean any of the mountains of the Blue Mountain range farther North. 
Penn had to decide what to do with the Moravian Indians. The report warned that over two hundred men were on their way to Province Island, and the Moravians only had fifty men guarding them. Additionally, Pennsylvania settlers were disregarding the Governor by aiding the vigilantes, further weakening any hope of a lasting peace between settlers and Native Americans on the Pennsylvania frontier. On January 3, 1764 the Governor wrote a letter to the Assembly asking for funds to raise a force to fight against the Paxton Boys. ${ }^{71}$ Yet, in his letter to the Assembly, Penn did not stress the importance of helping the Native Americans, but rather the importance of stopping the vigilante actions: "I must beg your serious and immediate attention... and hope that...you will furnish me with full powers to repel those bold Invaders of Law and Justice, \& support the Honour \& Dignity of the Government." 72 This could be evidence that the goal of Penn was not to stop the killings of Native Americans, but to stop men who challenged the authority of the colonial government. This does not necessarily mean that the Governor did not fear for the safety of the Moravian Indians. He could have believed that to sway the Assembly it was best not to plead for the safety of the Native Americans, but to appeal to the law. However, the Assembly was mostly comprised of Quakers and it is well documented that they hesitated when it came to funding actions they felt could lead to violence. ${ }^{73}$ Regardless

\footnotetext{
71 MPCP, 9:109.

72 MPCP, 9:109.

73 This was mentioned in chapter one when Governor Morris wanted to raise a force for the Ohio River Valley, but was not given the total sums that he felt were needed, and instead had to rely on Virginia forces to protect land that was claimed by Pennsylvania. B. Hindle, The March of the Paxton Boys, 464. The Assembly (which is voted for) lost some Quaker members and then voted for a militia law in 1756.
} 
of the motives or tactics, the Assembly acquiesced and promised an unnamed amount to help deter the Paxton Boys.

However, the same day the Assembly received the letter from Penn, January 3, 1764, Penn and his council determined that the best course of action was to remove the Native Americans from Philadelphia and Pennsylvania entirely ${ }^{74}$. This would take them away from the Paxton Boys and the disgruntled white settlers, effectively resolving the tension. Even though the Minutes mentioned that the Native Americans themselves had "requested they might be put under a proper Convoy", there was no evidence of a request made this early in their internment in either the communal diary or Moravian letters. ${ }^{75}$ It could be that the Moravians only made this request in person. It is also possible that the Moravians requested in a letter that no longer exists, or it could even be that the Moravians had not made the request, but the English were claiming one to make the decision seem more compassionate.

Penn wrote letters to the governors of New York and New Jersey to prepare the way. The Moravians were to be moved to New York, under the protection of Sir William Johnson, the Superintendent of Indian Affairs, in Johnstown, New York, before they continued on to live with friends and family along the Susquehanna. ${ }^{76} \mathrm{He}$ wrote a letter to Governor Franklin of New Jersey on January 4, 1764 requesting that the governor allow the migrants to pass through the

${ }^{74}$ MPCP, 9:110.

${ }^{75}$ MPCP, 9:110; Kenny, Peaceable Kingdom Lost, 142. Kenny also, on page 142, mentioned that the Moravian Indians requested removal to Johnson's land, but does not have specific citations that prove this assertion. ${ }^{76}$ MPCP, 9:110-13. These letters are replicated in the minutes and were read for the Governor's council. 
colony. ${ }^{77}$ The letter to Governor Colden of New York was a bit more informative while repeating the request. In this letter he suggested that by sending the Moravian Indians to New York and away from the vigilantes that threatened them, it would be clear to the Iroquois that the government was still treating the Moravian Indians compassionately, regardless of the threats of the vigilante groups. ${ }^{78}$ It seems probable that Penn assumed that the Moravians and their converts would be able to pass through colonial lands on their way to Johnson's land, and from there on toward the Susquehanna.

On January 4, 1764, David Zeisberger, Moravian missionary, came to the barracks and told the Moravians they would be leaving that night. They left at midnight and went by boat to Ludwig Weiss' farm, and from there loaded up the carts and left for Philadelphia. According to the diary entry, the plan was to go to Philadelphia and then continue onto New York where they would be under the protection of Johnson..$^{79}$ The following day, January 5, 1764, the Moravians began their journey to Johnson's lands in New York. When they left Philadelphia, large crowds surrounded them, but later they joined Highland soldiers from Pittsburgh who were on their way to Bristol. On the $6^{\text {th }}$, they reached the ice-covered Delaware river, and it took two hours to cross to Trenton, where they met Captain Roberson who took the refugees to barracks for shelter.

77 MPCP, 9:113.

${ }^{78}$ MPCP, 9:112-13.

${ }^{79}$ Engel, "Bethlehem Digital History Project, Amboy 1764," Bethlehem Pennsylvania Moravian Indian Diaries at the Bethlehem Digital History Project, January 4, 1764, accessed April 20, 2018, http://bdhp.moravian.edu/community_records/christianindians/diaires/amboy/1764amboy.html. 
Given the immediacy of their flight, the Moravians had to wait for the barracks master and wood, but they were treated well, with an ox killed and bread baked for their provisions. ${ }^{80}$

Franklin of New Jersey, having consented to the request of Penn, sent a passport which allowed the Moravians to pass through New Jersey unhindered. ${ }^{81}$ They continued without much issue and made their way to Amboy by January 9, 1764. The following day they were to cross into New York, but the weather was rough, and they had to postpone the voyage to the next day. However, on January 11, 1764, New York ferrymen turned the Moravian refugees away. The diary entry from that day showed that the Moravian refugees "were more than a little upset by this news" when New York refused them entry. ${ }^{82}$ This entry showed several interesting points. Penn received from General Gage, General Amhurst's successor, dated January 10, the day the Moravians refugees were waiting in New Jersey due to the weather. Gage's letter warned Penn that Colden opposed the arrival and admission of the Moravian Native Americans into New York: "not to receive the Indians within this Government, or suffer them to pass through the Province, but to issue the proper Orders to the Justices and Magistrates of Richmond County to stop \& cause them to return." 83 This letter from Gage showed the pitfalls of decisions made without the expressed agreement of other colonial and provincial leaders. By the time that Gage had received the letter from Penn, the Moravians were already in Amboy, having made a

\footnotetext{
${ }^{80}$ Engel, "Bethlehem Digital History Project, Amboy 1764."

${ }^{81}$ Engel, January 8, 1764.

${ }^{82}$ Engel, January 11, 1764.

${ }^{83}$ MPCP, 9:120.
} 
seventy-mile trek during January. Penn, however, did not receive this letter from Gage until January 13, at which point the Moravians were on their way back to Philadelphia. Colden's letter to Penn arrived on January 15, 1764, after receiving the request on January 7. In this letter he explained the reasoning behind his and his council's decision to prohibit the Moravian Indians purchase into the colony:

I have accordingly sent Orders to the Magistrates of Richmond County not to suffer these Indians to enter this Province. The Indians on the East side of the Susquehanna are the most obnoxious to the People of this Province of any, having done the most mischief. They consist of a number of rogues and thieves, runaways from the other Nations, and for that reason [are?] not to be trusted. I could not be assured that these Indians can safely pass through this Province without an Escort, which would with great difficulty and expence [sic] be obtained at this Season of the Year. The minds of the people are so generally irritated against the Indians living on the North East Branches of the Susquehanna, that a number of Volunteers were proposed to me to go out against them to punish them for their Cruelties \& perfidy. ${ }^{84}$

The boundaries of the colony did not stop tensions that plagued Pennsylvania. According to Colden, the Moravian Indians were untrustworthy due to their proposed relocation plan. Given

\footnotetext{
${ }^{84}$ MPCP, 9:120.
} 
that they were looking to reside with other displaced tribe members, family, and friends on the northern branches of the Susquehanna, and that the New York colony did not hold the Native American groups in high regard and viewed the Moravians negatively. The colony was not willing to try and raise a force to guard the Native Americans on their way. as the troops guarding them were not slated to continue to Johnson's. Lastly, the English colonists in New York shared the suspicion and distrust of Native Americans that the Paxton Boys had. The fact that colonists had approached Colden to form squads to "punish" Native Americans. This indicated that New York would have been as threatening to the Moravian Indians as Pennsylvania. Given the fact that Colden did not specify his response to the colonists, it is possible that he was in line with their ideas.

In this communication to Penn, Colden enclosed a copy of the New York Council's minutes for January 9, concerning Penn's letter and the stance of the Council. The Council's stance mirrored that of the Governor, with an additional twist - anger that Penn had assumed New York would go along with the plan to remove the Moravians from Pennsylvania. "The Council expressed their surprise that the Government of Pennsilvania [sic] should... order so great a body of Indians... to pass into this Providence." ${ }^{85}$ Not only were New York colonial leaders dismayed that Pennsylvania would take dramatic action without proper requests, they also stated plainly what Colden alluded to - that they as a government were more apt to side with the violence against Native Americans "to attack \& punish" than they were to try and help the

\footnotetext{
${ }^{85}$ MPCP, 9:121.
} 
refugees. In fact, they viewed the Moravian Indians as an extension of the suspicious Susquehanna Native American groups. They assumed that those groups would assimilate the Moravian Indians, "adding greatly to the strength of a people", aiding future attacks against New York settlers. Their sympathy toward their settlers, who "have already suffered so much", did not extend to sympathy toward the Moravian Indians. ${ }^{86}$ Despite the violence Pennsylvania settlers had acted upon the pacifistic Native Americans, it seemed that the colonial leaders of New York doubted the Native Americans' ability to remain pacifistic and removed from the tensions that plagued them in the northern colony.

Penn could have easily prevented many of the problems that surfaced during the pilgrimage to Amboy if he had not tried to rush the Moravians out of Philadelphia. Franklin of New Jersey acquiesced to Penn's request, but it is likely that he did so because New Jersey was not the colony of destination, only a stop on the way to New York. Colden, however, had determined that allowing the Moravians into New York was too great a risk for both the Moravians and the colonists. There is little doubt that those in New York did not want any additional Native Americans in their colony. When New York turned the Moravians away, they initially remained in New Jersey for days waiting for a decision on where they were to go. On January 14 , the pilgrimage diary noted that a message came late in the evening in which Franklin promised them protection. ${ }^{87}$ His protection did not have to last long, however, since on January

\footnotetext{
${ }^{86}$ MPCP, 9:121.

${ }^{87}$ Engel, "Bethlehem Digital History Project, Amboy 1764.” January 14, 1764.
} 
15 they received a message from Fox which told them they would be returning to Philadelphia immediately. This letter also said that the Pennsylvania government was upset with the actions of New York..$^{88}$

According to the council minutes, Penn sent a letter to the Assembly on January 16, 1764, one day after Fox told the Moravians to begin the trek back to Philadelphia. This letter acquainted the Assembly to the following: the requests of Penn to Franklin and Colden, the acquiescence of Franklin and the denial of Colden, and the subsequent return of the Moravian Indians to Philadelphia, where uncertainty would once again surround them. ${ }^{89}$ The Assembly, comprised of several Quakers, was disappointed that the Moravian Indians would not be sent on to Johnson, but were pleased that Gage agreed to send the soldiers who had been marching to Staten Island back toward Philadelphia as an escort for the Moravians. The problem of what to do with the group once they were in Philadelphia, however, remained. The Assembly suggested to Penn that he place the Moravian Indians in a place where the government could monitor and protect them easily. ${ }^{90}$

The return trip to Philadelphia was not as easy as the journey to New Jersey. Not only was the Raritan River at Brunswick (New Brunswick), New Jersey, frozen, the soldiers assigned to protect the Moravian Indians treated them poorly. Captain Schlosser with about one hundred and seventy soldiers replaced the original guards, the Highlanders. These new soldiers physically

\footnotetext{
${ }^{88}$ Engel, January 15, 1764.

${ }^{89}$ MPCP, 9:122.

${ }^{90}$ MPCP, 9:123-24.
} 
attacked one of the Moravian Indians, a woman named Elizabeth, accused the Moravian Indians of theft, and, in general, acted in an undisciplined manner-drinking and fighting nightly. ${ }^{91}$ On January 24, 1764 the Moravians reached Philadelphia: "We came happily back to Philadelphia and were immediately lodged in the barracks; a watch was placed before our house." 92 The Governor and his Council must have decided to heed the suggestion of the Assembly, and they placed the Moravians in the city's barracks, a little more than a mile from the Pennsylvania State House, now called Independence Hall. The Moravian congregation remained in the barracks until they left Philadelphia in March 1765, a little more than a year's time. During this period, they consistently lacked provisions and the citizens treated them like exhibitions rather than human beings. ${ }^{93}$ This was a distinct change from the riotous mob that greeted the Moravian Indians two months prior, with this change in perception among possibly linked to the violence the Paxton Boys brought to the Conestogas. When the Moravians initially entered the city in November the Paxton Boys had not yet acted upon the threats they made. By January, however, the Paxton Boys had murdered twenty Conestogas and had threatened to march on the city. The killing of the Conestogas showed the city population that the vigilante group was willing to kill pacifistic Indians. The movement against the city caused the city to unite in support of the Moravians and against the frontier settlers.

${ }^{91}$ Engel, “Bethlehem Digital History Project, Travel Diary 1764," Bethlehem Pennsylvania Moravian Indian Diaries at the Bethlehem Digital History Project, accessed April 22, 2018, http://bdhp.moravian.edu/community_records/christianindians/diaires/travel/1764travel.html.

92 Engel, "Bethlehem Digital History Project, Philadelphia Barracks 1764," Bethlehem Pennsylvania Moravian Indian Diaries at the Bethlehem Digital History Project, January 24, 1764, accessed April 22, 2018 , http://bdhp.moravian.edu/community_records/christianindians/diaires/barracks/1764/translation64.html.

93 This is not unlike other periods where unusual people were put on display for the masses. 


\section{Paxton Boys}

The Paxton Boys did not give up on their terrorism on the Pennsylvania frontier. On February 4, 1764, Penn and the council met to discuss rumors of continued threats to the Moravian Indians housed in the barracks. The council received a letter from Lancaster which warned that the vigilante group was "assembling themselves with and intention of coming to this City to put to death all the Indians in the Barracks under the protection of this Government." 94 Penn immediately sent word to the soldiers to be on watch, and the council also suggested that one hundred fifty men of Philadelphia be raised to help the soldiers protect the Native Americans who were bring threatened..$^{95}$ In light of the news, Penn passed a riot act and about one thousand citizens took up arms to protect the city—and, by default, the Native Americans. ${ }^{96}$ The citizens, including about two hundred Quakers, armed themselves and surrounded the barracks where the Governor kept the Moravians. ${ }^{97}$ The communal diary reported the tension of the city during these preparations. Soldiers told the Indians to "move to the second story" in case the rooms were "broken into". The tensions increased when "a couple shots happened outside the barracks", but there was no indication as to who fired them: "Eight cannons were mounted...in the middle of the square" in order to protect the barracks and the Indians. ${ }^{98}$

\footnotetext{
${ }_{94}^{94}$ MPCP, 9:132.

${ }_{95}$ MPCP, 9:132.

${ }^{96}$ Hindle, 475.

${ }^{97}$ Hindle, 476.

${ }^{98}$ Engel, "Bethlehem Digital History Project, Philadelphia Barracks 1764."
} 
Once again, vigilantes terrorized the Moravian Indians and those who protected them. There is little evidence as to why someone fired shots outside of the barracks, but no doubt that it made those who were under guard anxious. It could have been that guards had mistaken citizens for the vigilantes and fired a volley, or that there were vigilante sympathizers among the citizens who opened fire on the barracks. It could also have been that there were misfires outside the barracks - although given the number of steps it takes to ready a musket that seems less likely. Regardless of the reason for the shots, the guards tried to keep the Moravian Indians safe, and for the next few days the Moravians were under the careful watch of the city.

On February 6, 1764 the diary recorded an escalation of the tension: "At midnight a great alarm was sounded. Everyone took up arms, the bells in the city were rung...because the news came in that the rebels would be there at daybreak." 99 A group of citizens, led by Benjamin Franklin met the Paxton Boys in Germantown. There they explained their actions, and two men, Matthew Smith and James Gibson, stayed to write and record their arguments, which then became $A$ Declaration and Remonstrance of the Distressed and Bleeding Frontier Inhabitants of the Province of Philadelphia. The gentlemen of the city must have accepted the men's position and declared them not an immediate threat, since the citizens who had been protecting the Moravian Indians were dismissed after their return. ${ }^{100}$ The next day the Moravians received word

\footnotetext{
${ }^{99}$ Engel.

100 Hindle, 480.
} 
that the vigilantes were demanding some of their Native American men "that they allege to have seen in Pittsburgh and in other places."101

There is no conceivable way that the Paxton Boys saw any of the Moravian Native Americans - they had been under the protection of the Pennsylvania government since November of the previous year. The vigilantes demanded the ability to check the Native Americans, though, and the government granted them permission to inspect the Indians, as the diary records: "Mr. Huse, the Commissioner, visited all our Indians with one of the Paxtons and looked at them closely, but he recognized none." 102 The political divisions in Pennsylvania must have encouraged the government to appease the vigilante group. While many within the city armed themselves to protect the Native Americans who were in the barracks, most people outside of the city supported the actions of the vigilante group. The political climate of the citythanks in large part to the recent immigration of Scots-Irish and the racialization of the Seven Years' War - was changing, and the tide was turning away from the peaceful past the Quakers supported. The Commissioner, by escorting a member of the vigilante group, could have recognized that these men had power in the frontier, and within some of the sectors of the city. The Paxton Boy left after inspecting the congregation and failing to positively identify any violent offender. This intrusion on the Native American personal space by those who meant them physical harm suggested that the government was not genuinely interested in protecting the

101 Engel, "Bethlehem Digital History Project, Philadelphia Barracks 1764."

102 Engel. 
Native Americans from their would-be attackers. Rather, government leaders allowed a man connected to the Conestoga murders to walk among those the government protected. Despite the decision to allow a member of the vigilante group in to inspect the Native Americans, the diary recorded that the Moravians were pleased: "Above all, many people are pleased that the matter is concluded so well and without bloodshed." ${ }^{103}$ It is possible, although unrecorded, that the Moravians gave permission to the leaders of the city to allow a single Paxton into the barracks, while knowing that their Native American converts were innocent from the suspicions the vigilantes had.

After the threat to the city in early February, Penn received a letter from Smith and Gibson, dated February 13, that detailed their grievances with the Native Americans and the Quaker Assembly. A Declaration and Remonstrance of the Distressed and Bleeding Frontier Inhabitants of the Province of Philadelphia outlined several points with which they justified their hatred against and violence toward the Native Americans, even naming the Wyalusing and Moravian Indians. As the letter described, "And as to the Moravian Indians, there are strong Grounds at least to suspect their Friendship, as it is known they carried on a Correspondence with our Enemies on the Great Island (Lock Haven, Pennsylvania)."104

This letter proved that many settlers who lived outside of the city were angry at what they considered preferential treatment of government toward the protected Native Americans, as they

\footnotetext{
${ }^{103}$ Engel.

${ }^{104}$ MPCP, 9:140-41.
} 
accused the government of neglect, "while our suffering Brethren on the Frontiers are almost destitute of the necessities of Life." ${ }^{105}$ The settlers claimed to be justified in the murder of three Native American men because those men were on their way to Great Island, "which is an undeniable Proof that the Moravian Indians were in confederacy with our open Enemies." Yet they also say that they surprised the men: "who attempted to shoot us when we surprised [sic] them." 106 If they surprised the men, then it is probable that they saw them on the Great Island Path which was a path that connected Shamokin to Great Island. This path, however, was a welltravelled path and connected many villages in the frontier. ${ }^{107}$ While it is possible that these men were taking goods and provisions to Great Island from Bethlehem, it is more likely that these two English settlers assumed they were heading to Great Island. Further, while it may have been that these Native American men that Smith and Gibson admit to killing were Moravian Indians, it is also possible, given what we know about the openness of Moravians in their interactions with all Native Americans, that they were not technically affiliated with the Moravian church at all.

The Paxton Papers and the Declaration and Remonstrance exhibit less racism and animosity toward Native Americans, and the Moravian Indians, than the minutes and the diaries. It is possible that the Paxton Boys recognized that they could better promote their message if they had enemies that were not pacifistic Indians. In the Paxton Papers they highlighted

\footnotetext{
105 MPCP, 9:140-41.

106 MPCP, 9:140-41.

107 Wallace, Indians in Pennsylvania, 64.
} 
Papunhang as someone who continued to have interactions with Native Americans of questionable loyalty, relying on the suspicions that had grown in the frontier. By listing grievances against the Quaker Assembly, they made a political argument: these leaders were unable to protect us, and they maintained relationships with those who threatened us. Additionally, the Paxton Boys were outraged that the Governor and the Assembly offered a reward for their capture after the murder of the Conestogas but did not offer any reward for Indians who targeted white settlers. ${ }^{108}$ Yet, it seems that if their dispute was originally with the Quaker Assembly, there would have been no obvious reason to threaten and kill the Conestoga Indians and target the Moravians. Instead, the focus on the Assembly and the Quakers came after Philadelphia pushed back the Paxton Boys.

Even with the immediate threat from the Paxton Boys gone, the government's decision to remove most of the guards in April left the Moravian Indians susceptible to threats. There were still those within the city who wished them harm, and church and governmental leaders reminded the Native Americans that their safety lay in the barracks. In fact, on June 27, 1764, Fox warned the Native Americans not to leave the protection of the barracks, because they could not trust the people outside in the city: "Mr. Fox visited us, spoke with our Indians, and reminded them not to go out of the barracks because...there were very many mean people in the city who did not wish us any good." 109 This reminder surely reinforced the fact that the Moravian Indians were not safe or secure in a place where the government had promised safety and security. The government

${ }^{108}$ Engels, 369.

${ }^{109}$ Engel, "Bethlehem Digital History Project, Philadelphia Barracks 1764." 
and the people of Pennsylvania continuously demonstrated that the Moravian Indians were not members of the community. It is certain that this tense time was a shared experience that the congregation would rather not have endured. The city was a place of relative safety, but it was also a place that limited the freedom of the Indian congregation. The Moravian Indians were only safe if they remained within the confines of the barracks, a life completely counter to the freedom of movement they traditionally enjoyed.

\section{Desire to Leave}

There should be little surprise that many Moravian Indians wanted to leave Philadelphia and the barracks. Yet Colden's refusal to allow the Moravians entrance into New York to reach Johnson's land limited the Moravians' choices. Despite Colden's strict stance against the Moravian Indians' passage, Penn was still in contact with Johnson, trying to discover a way to remove the Moravian Indians from the city. A letter Penn from to Johnson, dated February 17, 1764, explained the troublesome situation in which the Moravian Indians, and the Pennsylvania government, found themselves. ${ }^{110}$ The city may have denied entry to the Paxton Boys, but the tensions they brought with them remained. Newspapers and publishers printed their Declaration and many settlers connected with their ideas and arguments. The people on the frontier were suspicious and wanted vengeance against the Christian Indians for perceived wrongs, the government was unable to fully protect the Moravians, and the Moravian congregation itself

\footnotetext{
${ }^{110}$ MPCP, 9:138.
} 
continued to ask the government to release them into Indian lands. In this letter to Johnson, Penn hoped that Johnson could write a referral to Colden so that he might be able to get the Moravian Indians into the upper Susquehanna, which was the original plan in January. ${ }^{111}$

European Moravians were aware that the government was attempting to remove the Native Americans from the city. Whether they acknowledged this based on the neglect that the Moravian Indians had experienced, or on unrecorded discussions with the colonial leaders, by March 2, 1764, Moravian leaders were writing about their options moving forward. In a letter to Frederick Marshall in Bethlehem, Louis Weiss wrote about the uncertain future of the Indian congregation. ${ }^{12}$ The letter from Weiss showed that the Moravian leaders, or at least the European ones, were receiving updates with the information the Governor was receiving from Johnson. Moravian leaders recognized the motives of the government, wanting to remove the Moravian Native Americans, yet there was no place where they could go. Weiss also recognized that it was beneficial to everyone, both "friends and foes", for the Moravians to leave Philadelphia. The city was not completely hospitable to the converted Indians, and the frustration of the Moravian community was going to increase the longer they remained in the city. The letter also indicated continuing negotiations as to where they would relocate. If Johnson could not get Colden to agree on the Moravians' movement through the colony, they would have to find a new home.

${ }^{111}$ MPCP, 9:138.

112 "1764 Letter from Lewis Weiss to Frederick Marshall," Bethlehem Digital History Project, accessed April 28, 2018, http://bdhp.moravian.edu/personal_papers/letters/indians/1764weisssource1.html. 
At this point Schmick was still optimistic that the Moravians, both Indians and Germans, would be able to return to the frontiers of Pennsylvania. On March 19, 1754, Schmick went to the Governor and asked when they would be able to leave. ${ }^{113}$ Penn told Schmick that the colonies were still discussing matters. By March 23, the discussions among the colonial governments concerning the passage of the Moravian Indians was not progressing well. The diaries note "We heard that one does not want us to have permission to move through New York." ${ }^{114}$ We can assume, based on previous actions by Colden, that the Governor and the Council of New York was trying to stop their passage.

These events, however, did not dissuade the Moravians. On April 7, 1764 Schmick and Zeisberger returned to the Governor to discuss how the Moravian Indians might leave Philadelphia: "They came back home however without any hope that our poor Indians might be helped. Our dear Indians were totally downcast by this news." 115 The colonial leaders were hesitant to release the Native Americans into the frontier. On April 10, the Governor requested that the Moravian Indians explain to his secretary any plans to reach Johnson in New York. ${ }^{116}$ After the Native Americans told the secretary a plan they created, the secretary said that he would report back to the Governor, and he assured them that the Governor wanted to see them returned to their own land. ${ }^{117}$ While this may seem like admirable rhetoric on the Governor's

\footnotetext{
${ }^{113}$ Engel, "Bethlehem Digital History Project, Philadelphia Barracks 1764,” March 19, 1764.

${ }^{114}$ Engel, March 24, 1764.

115 Engel, April 7, 1764.

116 This plan included a guarded escort within Pennsylvania that would leave the Moravian Indians at the

${ }^{117}$ Engel, April 10, 1764.
} border of New York. 
part, the Moravian Indians were not requesting a return to their own land, which lay in the Pennsylvania frontier in the Susquehanna River Valley. Rather, they recognized that their final location would not be their traditional land but land a bit farther north. Too many hostile settlers had begun to overrun the Pennsylvania frontier. Additionally, the Governor did not want the Moravian Native Americans on their traditional lands, despite what his secretary said. The actions of Penn proved that his desire was to remove the Moravian Indian congregation from Pennsylvania entirely. Doubtless, this was not only to 'protect' the American Indians, but also remove one ingredient of the continued tension from the frontier.

On April 11, 1764, Penn met with his council. At the meeting they discussed the possibility of removing the Moravians from the barracks, as well as from the colony altogether. He wanted to "take immediate Measures for the removal of the Indians now in the Barracks here, and send them to Johnson, or elsewhere." While his representative told the Moravians that Penn wanted them to get back to their lands, here we can see that he did not particularly care where they eventually settled. Johnson's land was in central New York, but the record showed that 'elsewhere' was also acceptable to Penn. The Governor seemed more concerned about the financial burden that the Moravian congregation placed on the provincial government, as he mentioned, "that the maintenance of them here was... a very heavy expence [sic] to the Province, and...it would be incumbent on us to support them till next Spring at the public Expence [sic].” He recognized the city obligation to continue their financial support of the congregation unless the Moravians could get out of the area to a location where they could be self-sufficient.

In this meeting Penn also provided the council with letters he had received from Gage and Johnson. The letter from Gage, written from New York on March 9, showed the complexity 
of the Moravian Indian situation, as well as the prejudice they faced from the leadership of the colonies. ${ }^{118}$ One must remember that Gage was the commander of British forces in North America, having replaced Amhurst after Pontiac's War had begun in 1763. His perspective was one of a soldier strategizing against his enemies, recognizable in the way in which he wrote about the Moravian Native Americans. While the Moravians viewed faith as above tribe or ethnicity, Gage, obviously, assumed that the Natives placed their tribal and Native American identity over their Christian one. Gage's continued to use the word "savages" to identify the Moravian Indians, which showed his prejudice against both them and their plight. Gage also assumed that the murder of the Conestogas and continued vigilante threats against Native Americans caused Moravian "resentment" against the colonial government: "the resentment of those Savages must be Strong against us for the miserable Fate of the poor Wretches who were murdered at Lancaster, and for the attempt made on their own Lives." ${ }^{119}$ While the diaries showed that frustration against the government within the congregation in the barracks was beginning to mount, there was little evidence of resentment toward the government or a desire for vengeance against white settlers. Gage was projecting what he expected Native Americans to emote, based on his experience as a soldier and commander, not recognizing that the Moravian Indians might be different.

\footnotetext{
118 MPCP, 9:170-71.

${ }^{119}$ MPCP, 9:170-71.
} 
It is clear that Gage felt the Iroquois and the English had an agreement: "They might set this affair in such a light before the Six Nations, as would make a change in the present good disposition of those Indians towards us, which at present is as friendly as we can wish or expect." ${ }^{120}$ He worried that if the Moravian Indians went to the Iroquois and complained about their situation, the relationship between the England and the Iroquois constructed after the Seven Years' War would be in jeopardy. In the world as he saw it, ethnic or racial loyalty would undermine diplomatic alliances. Additionally, he made it seem inevitable that the Moravian Indians would make their way up to the Iroquois, but this was far from certain given that Moravian Indians were of Delaware and Mohican background. While their tribes were officially associated with the Iroquois, they also had agency — a fact underscored by created and broken alliances during the French and Indian War. The Moravian Indians, while still interacting with friends and kin, considered themselves Moravian and seemed, after 1754, to have moved away from many of the tribal politics.

Further, Gage recognized the Moravians as captives who were living in the city, writing "Those Savages are now in our power; they are a sort of Hostages for the behaviour of their Nations, and effectually prevented from doing Mischief themselves." While he posed the situation as "sort of Hostages", he saw that they were under the "power" of the government, where they were unable to work against the English. It was obvious that he felt that this was an agreeable solution to the problems that currently plagued the colonies. According to Gage, the

\footnotetext{
${ }^{120}$ MPCP, 9:170-71.
} 
"savages" (Moravian Indians) were "Hostages" due to the "behaviour of their Nations", rather than for actual protection from the savage threats of settlers. He conflated the tribal or racial identity of the Native Americans and ignored the fact that these Native Americans were pacifistic Christians who were trying to live safe lives. His misunderstanding of the motives of the Moravian Indians coincided with continued raiding and warring with the Delaware, the Nation that many of the Moravian converts identified as. The last paragraph of the letter displayed the "pleasure" of reporting that "friendly Indians" took dozens of Delaware hostage. It is important to note that those Native Americans that helped Gage were not minimized to their tribal identity, instead named merely as "friendly Indians", while the offending Indians were recognized as Delawares. This indicates that Gage had a particular enmity toward the Delaware, despite the possibility that some of those "friendly Indians" were also originally from Delaware tribes. ${ }^{121}$

Gage's mentality, conflating the Native American tribal identity to generalized Native Americans and vice versa, was not unique to him. In fact, the lines of Native American identity for European settlers during the period surrounding the Seven Years' War became less individualized or tribal. Native Americans, regardless of tribal affiliation, became enemies and savage, whereas prior to the war, individual groups were recognized as unique and separate. ${ }^{122}$ Scholars speculate that this racialization came not only from the war, but also from the influx of immigrants, especially Scots-Irish, who did not have the Quaker history of friendship and

\footnotetext{
${ }^{121}$ MPCP, 9:170-71.

122 Silver; Merritt, At the Crossroads, 4-12.
} 
pacifism with the Native Americans within the colony. ${ }^{123}$ By defining the Native Americans who helped the English as friendly Indians, a generalization without a distinguishing identity, Gage was indicating that all Native Americans were one and the same. While he called out the Delaware, it is probable that his distinction was one of enmity — he knew the Delaware as enemies, even though there were Delaware as allies on both sides of the fighting. He also did not distinguish the Moravian Indians as separate from an Indian signifier. He showed this by assuming that the Moravian Indians would seek retribution over their treatment and the deaths of the Conestogas. Despite the arduous work of the Moravians to create a Christian community, many settlers, like Gage, refused to recognize them as separate from an overarching Indian signifier.

Despite the wishes of the Moravians, and the financial concerns of the city, the Pennsylvania government decided that the best course of action was to have the Moravians remain in the barracks within the city. Penn told the Moravian leaders his decision on April 12, 1764, saying that "he...had considered our circumstances, [but] they could not give us permission to go to New York and settle there." 124 The diary entry explained the decision of the governor who, like Gage, must have had enough misgivings to force the Moravians to stay. While we cannot know for certain his primary motivating factor, this entry indicated that he felt a paternalistic obligation to the safety of the Moravian Native Americans, a stance Gage did not

\footnotetext{
${ }^{123}$ Engels; Merritt, At the Crossroads, 285-88; Gordon, "The Paxton Boys and the Moravians."

${ }^{124}$ Engel, While this entry said that they would be moving to Province Island again, the congregation did not return to the island, and instead remained in the barracks for better supervision and protection.
} 
share. ${ }^{125}$ In the Provincial Minutes, Penn and the council did seem to have a sense of obligation to the well-being of the Moravians, but those sentiments seemed secondary to the economic aspect of removing the Native Americans from the colony. It is possible that given the political tensions of the city, and the ideological distance between the Quaker Assembly and the provisional government (led by the Governor), that Penn was worried about political opposition if harm came to the Moravian Indians. Councilman Logan, on a trip from Lancaster to Philadelphia, wrote that seventy five percent of the frontier supported the Paxton Boys, even before the publication of their arguments. ${ }^{126}$ Publishers released the Declaration and Remonstrance of the Paxton Boys in February, after which a pamphlet war proceeded to divide the already tense politics of the city. The support that Logan saw in the frontier for the Paxton Boys led to political action against the Assembly. ${ }^{127}$ The Governor and the Assembly had been fighting for control of the colony for decades, with the Paxton Boys' anger with the Quaker backed Assembly, the Governor saw a political advantage. The popularity of the Paxton Boys on the frontier united non-Quaker citizens. However, if Penn allowed the Moravians to leave the barracks and the Paxton Boys' factions killed the peaceful Indians, it was possible that the Quakers would be able to use that event to strengthen their political positions in the colony.

${ }^{125}$ Engel, "Bethlehem Digital History Project, Philadelphia Barracks 1764,” April 12, 1764. The diary also stated that "In the current situation, we could not be sent to Indian country, because we would lack for food and could quite easily come into danger of being attacked by enemy Indians. Also, we could easily be blamed if a murder should be committed on the border."

${ }^{126}$ Hindle, 474.

${ }^{127}$ Engels, 368. 
The tensions between the Native Americans and settlers in the frontier that caused some of Penn's misgivings were compounded in June 1764 when Penn, with the agreement of Johnson, began offering white frontier settlers money for Delaware and Shawnee scalps. ${ }^{128}$ This decision was based on one of the grievances the Paxton Boys had against the government. ${ }^{129}$ The Governor, through this action, was effectively siding with the Paxton Boys and their supporters against the Quaker-backed Assembly and the Moravians. We can see based on this action that the fighting on the frontier, regardless of the actual status of war, was not relenting. Prior to the war, Assembly leaders, based on their Quaker heritage, had been loath to approve funding for a militia. After the war, however, there were already soldiers under the command of the crown and the colonies. Penn, obviously, wanted to end the fighting between the Delaware, Shawnee, and the white settlers. However, instead of continuing diplomacy or calling the army in to further deal with the raids, Penn decided to give settlers incentive to kill Delaware and Shawnee, effectively removing them from the frontier.

The desperation and impatience of the colony was evident. By offering "great rewards" for "all Indian Enemy Prisoners \& Scalps", Penn hoped to force the Delaware and Shawnee out of the eastern frontier of the colony. ${ }^{130}$ While Penn wrote and spoke of the Moravian Indians with paternalistic undertones, this record showed that these Delaware and Shawnee were considered "Savages". ${ }^{131}$ The Native Americans were being labelled together as one group in the

\footnotetext{
${ }^{128}$ MPCP, 9:189-91.

129 Engels, 369.

130 MPCP, 9:188-89.

${ }^{131}$ MPCP, 9:188-89.
} 
European mind, continuing the growing trend elaborated on previously. Europeans transferred the actions of some Native Americans into defining attributes of the whole. Instead of some of the Delaware and Shawnee being guilty of acting savagely, Native Americans in general were savages. The Governor wanted to incentivize the killing of these Native Americans, which further promoted savagery and terror in the frontier. Many of the settlers in the frontier were already suspicious of Native Americans. The terrorism of the Paxton Boys, and the support they received from white settlers, indicated that they needed little incentive to kill American Indians in the Pennsylvania frontier. Yet, this proclamation also implied that incentive was necessary to "spirit up the People to pursue and harass the Savages in their own Country", since the record showed that they would need to provide "great rewards" for those who were captured or killed. ${ }^{132}$ This may imply that while the Paxton Boys received vocal support from other settlers, some of those settlers who supported them in theory were unwilling to support them in action. By offering a reward the government was legitimizing the Paxton Boys and their actions, while at the same time legalizing previously vigilante behavior.

This proclamation was an obvious play for the support of the Paxton Boys and their frontier supporters, which went into effect on July 7, 1764, and continued to raise tension the colony. The proclamation, however, did not allow for wholesale murder of Native Americans in the frontiers, and specifically excluded the Moravian Indians who were in the barracks: "And Whereas, sundry of the Delaware, Nanticoke, \& other Indians...in the barracks of this

${ }^{132}$ MPCP, 9:188-89. 
city...under the Protection of this Government... are expressly excepted and excluded out of this Declaration." 133 Yet, the Moravian and Wyalusing Indians were explicitly named in the Paxton Boys' threats. According to the proclamation, Penn allowed settlers to only target Delaware and Shawnee men and women. The governor required "all his Majesty's Subjects of this Province, and earnestly invite those of the neighboring Provinces, to embrace all opportunities of pursuing, taking, killing, \& destroying the said Delaware and Shawanese [sic] Indians."134 The proclamation specifically demanded that the Pennsylvania government required settlers to act violently toward Delaware and Shawnee, not only to capture or kill them, but to "destroy" them. This level of violence and hatred was state-sanctioned terror. By authorizing these actions, the Governor was declaring the Paxton Boys justified in their prior actions against Native Americans. ${ }^{135}$ After this proclamation, regardless of his own motives, the Governor would have been responsible for the well-being, and probable murders, of the Moravian Indians if he granted

133 MPCP, 9:191.

134 MPCP, 9:191.

${ }^{135}$ MPCP, 9:191. As a reward to those who were able to capture or kill Native Americans, the proclamation set prices for their capture and scalps. Most prisoners were worth more than scalps, and men ten and older were worth more than women. Men ten and above taken prisoner were worth one hundred and fifty pieces of eight. The government priced captured women and children, including young men under ten, worth one hundred and thirty pieces of eight. Scalps of men older than ten were worth one hundred and thirty-four pieces of eight, four pieces more than a captured woman or child. Scalps of women and children under ten were worth fifty pieces of eight. ${ }^{135}$ These prices are interesting for many reasons. First, the scalps of men older than ten (134 PoE) were worth more money than the capture of women and children $(130 \mathrm{PoE})$. This was, undoubtedly, due to the role of men as warriors and the effect that killing or capturing warriors would have on Native American raids and resistance. Given the fact that capturing soldiers would have been extremely difficult, turning in scalps to the colony would have been easier for the settlers. Killing a man would have been easier than capturing a soldier. However, it was also impossible to determine the actual age of the person's scalp. How could the colony determine that scalps taken were those of adults or older children? Also, while the proclamation ordered the targeting of the Delaware and Shawnee, it is highly unlikely that white settlers were questioning their quarry asking to what tribe they belonged. This proclamation made life on the frontier more unstable for all Native Americans. It led to a frontier where every Native American was a target for white settlers - and that was the goal of both the Governor and the Paxton Boys. 
their wish to leave the city. Penn created a situation in which the Moravian Indians would have been less safe in the frontier, while at the same time actively trying to remove them from Philadelphia. He and his Council continued trying to placate the Moravian Indians while younger Moravians kept petitioning the leaders to return to the frontier. The disregard for the Native Americans' desires led to eventual frustration and discontent.

Throughout the summer and autumn, the Moravians continued to petition the Governor to leave the barracks. Members of the congregation contracted and died from the pox, including young Johanna Schmick, only fourteen months old. The fear of continued exposure to the illness, as well as the apparent neglect of the government, spurred the petitions onward. The members of the congregation seemed split - those who wanted to stay in the safety of the barracks and the city, and those who wanted to leave the safety of the city for the freedom of the frontier, and by all accounts was a generational divide.

On August 14, 1764, Schmick went to Penn and, once again, told him the desires of the Moravian Indians, "namely: that they want to be in the wilderness again because they are so sick here."136 The barracks diary recorded the requests and showed the growing frustration of the Moravian Indians. It also indicated that Penn did not completely trust the Moravian Indians, especially the young people. "To that the Governor answered that it was now a pure impossibility to let them go to the wilderness, as long as there was war with the Indians; because as soon as there was a deadly attack on the frontier, then they would be given the blame, and he

\footnotetext{
${ }^{136}$ Engel, August 14, 1764.
} 
also did not trust all our young people." ${ }^{137}$ Here we can see that the Penn, like Colden and Johnson, probably worried that the Moravian Native American youth who felt dissatisfied would harness that frustration into alliances with the local Delaware and Shawnee. Additionally, he recognized that continued raids with the Indians on the frontier would lead to deaths. If Penn allowed the Moravian Indians access to the frontier, they could be blamed for raids and deaths and would, consequently, be a target to settlers who wanted to cash in on the gold that was promised in the proclamation. He would be unable to keep the pacifistic Moravians from the retaliation of the settlers. Of course, any retaliation against the Moravian Indians from white settlers would be the responsibility of the Governor and the government that permitted the Native Americans to leave the barracks in Philadelphia.

These assurances and rationalizations did not change the desires of the Moravian Native Americans, however. Two days later, Schmick and Grube returned to City Hall to let the Governor know that the Moravian Indians were unhappy with the decision and that Johan Papunhang, the prophetic leader from Wyalusing, wanted to meet with Penn directly. Penn, anticipating Papunhang's reason, warned that he would not allow him to go back to the frontier. ${ }^{138}$ The diary shows that the Moravians continued to petition the Governor for months. The Colonial Records do not provide further insight into the interactions with the Native Americans, but the diaries showed that some Native Americans received special passes to leave the barracks by October. On October 20,1764, the diary recorded that the congregation was

${ }^{137}$ Engel, August 14, 1764.

${ }^{138}$ Engel, August 16, 1764. 
getting impatient with the government, as negotiations with New York all but stalled. Despite the fears of the Governor, several men of the congregation decided to request that William Allen, the Chief Justice, allow them to leave the barracks. The congregation remained disappointed and impatient with the government and their decisions. The October 20th record showed that, regardless of the threats of the frontier, most of the Moravian Indians were determined to leave the city and the barracks: "Almost all our poor people have the intention of leaving, and therefore they work very hard to bring it about yet this fall." ${ }^{\prime 39}$ Further, it is not surprising that those who petitioned Allen included Johan Papunhang, who had been denied a meeting with Penn. By circumventing Penn and addressing Allen directly, Papunhang hoped to get his wish, and leave the barracks. This plea to Allen by the Native Americans indicates that they were aware enough of the political hierarchy of Philadelphia enough to recognize who they should address to force the colony's hand.

By November, several men, including Papunhang, left the barracks with Penn's permission, and went to the Susquehanna River Valley to find land for a new village. ${ }^{140}$ The diaries record: "They have acquired a Pass from the Honorable Governor without our knowledge and claim to look for a place for future settlement on the Susquehanna."141 This entry clearly indicated the tensions that were in the Moravian Indian congregation, since, "the other young

${ }^{139}$ Engel, October 20, 1764.

${ }^{140}$ These men were Old Josua, Johan Papunhang, Bartholomeas, and Josua junior.

${ }^{141}$ Engel, November 13, 1764. At some point Allen must have interacted with Penn to convince him to grant passage for several Moravian Indians into the frontier. Allen was Penn's father-in-law, Penn having married his daughter Anne. There is no record of any decision made between Penn and Allen in the Provincial Minutes. However, given their personal relationship, it is possible that the discussion and decision to allow the Moravian Indians passage was done outside of regular colonial business. 
people were very disappointed not to be allowed to go with them." These men petitioned for this pass, which the Governor gave them directly, without the knowledge of the European Moravian leaders, a unique circumstance in the diaries. In fact, the diaries did not further address this event - even though there were Native American men who circumvented the European Moravian leaders to interact independently with the government. This could imply that the frustration of the Native American congregants was so high that they began to act without the knowledge of the European Moravian leaders, which could, in turn, suggest that the European Moravian leaders were content to remain in Philadelphia. The desire of many Native Americans to leave was so immediate that they went against the unspoken rules of the community, where the European Moravian leaders were the negotiators between the Moravian Indians and the white settlers. There is little doubt that the European Moravian leaders were trying hard to maintain the peace and patience with an increasingly frustrated group.

The diary entry also indicated that Schmick believed the actual reason for their departure was to go on a hunt: "Their main goal however is the hunt." 142 Given the importance of hunting in traditional Native American life, it is understandable that other young people, young men especially, would be frustrated the government denied them a hunt. However, the entry also showed that the four Native American men received the pass because they claimed they were going to search out land for a new village. This indicates that they recognized that the Governor would not view their earnest desire — to hunt — as a credible reason to leave the safety of the

${ }^{142}$ Engel, November 13, 1764. 
barracks, especially since it was a request he had denied previously. Since the Governor and the Moravian Indians both wanted the congregation removed from the barracks, the claim that these four men were searching for a new location to settle was a valid reason to allow them passage from the city.

Penn knew by the end of 1864 that the fighting with the Native Americans on the frontier was ending. The Provincial Minutes recorded several negotiations between Gage and Native American leaders beginning in August, which were lengthy and concluded on December 5, 1764, when Penn signed a proclamation ending the fighting with the Native Americans. ${ }^{143}$ So, by November 13, when Penn admitted passage to the Moravian Indian men, he was aware that the fighting would soon be over. The Moravians heard of the peace treaty through hearsay on December 4, 1764. On the 6th a newspaper published the proclamation: "The Proclamation...said that no more hostilities will be committed against the Indians. The city folk soon made this known to our Indians, who were very glad." 144 Penn revoked the earlier proclamation that demanded the capture or kill of any Delaware or Shawnee by white settlers, "that they cease and forbear carrying on an Offensive War, or committing any Acts of Hostility against any of the said Delaware, Shawanese, or Seneca Indians..."145 This new proclamation seemed to give the Moravian Indians a chance to live on the frontier again.

\footnotetext{
143 MPCP, 9:192-234.

144 Engel, December 6, 1764.

145 MPCP, 9:234.
} 
It is not surprising that after the peace treaty was signed and the proclamation published, the Moravian Indians began preparing to leave the barracks for the frontier. There remained, however, the question of where they would travel to settle. Settlers and Iroquois had either taken or destroyed much of the land. On December 20, 1764 the men who had gone hunting and searching for lands returned to the barracks with news that "most everything is destroyed". ${ }^{146}$ The diary reported that "the Indians from the six nations wreaked havoc on the Susquehanna last summer, mowed down the corn, and spoiled things." 147 The Iroquois came in and ravaged the villages that traditionally belonged to the Delaware and other, smaller, tribes. It is possible that the Iroquois were trying to maintain the diplomatic agreement they had made with the English after the Seven Years' War was over—siding with the English, Gage, and Johnson against the Delaware and Shawnee. It is also possible that the Iroquois were retaliating against the Delaware, Shawnee, and some of their smaller allies for going against the wishes of the Iroquois and acting independently against the settlers. Most likely, Iroquois action was a combination of both: the Iroquois were upholding their alliance with the English while also punishing the Delaware and Shawnee for defying Iroquois wishes by attacking white settlers.

This diary entry also names a possible location for the congregation to eventually relocate. Leaders assumed that they would return to the Susquehanna River Valley within the Pennsylvania colony, but under the Iroquois sphere of influence: "Now they think they will

\footnotetext{
${ }^{146}$ Engel, December 20, 1764.

${ }^{147}$ Engel.
} 
move to the Susquehanna next spring, apparently a few to Machchilusing [Wyalusing], but others a few miles above Wajomick [Wyoming]." 148 While the earlier plans made by the Governor would have seen them on the banks of the Susquehanna in New York, it is evident that the Moravian Indians wanted to remain near their traditional land - even if they could not return to the villages or exact location. There was not consensus around a single spot, however, which could be evidence of the larger frustration among the community. Schmick noted that some planned to move to Wyalusing, while others chose a place north of Wyoming. This division could have been because Papunhang had lived in Wyalusing, and those who chose to move there were loyal to him rather than to the Moravians. It could also have been that those who decided to move to Wyalusing had kin and friends who would go back to the village to rebuild now that the fighting was over.

Still uncertain of their destination, the Moravians waited out the harsh winter of early 1765 in the barracks. In February, fear of the pox prompted two of the Moravian Indian men to petition Philadelphia authorities for permission to leave the barracks. ${ }^{149}$ Some Indians wanted to return to Nain, but when "Br. Nathanael's letter was read to the Indians," this wish "completely changed, because the white people were still hostile." ${ }^{150}$ In December the group had been considering a move to the Susquehanna valley, but in February they were considering returning to Nain, closer to Bethlehem. Undoubtedly, the continued tensions of the frontier drove this

\footnotetext{
148 Engel. Machilusing, or Machchilusing, is another name for Wyalusing, the village of Papunhang.

149 Engel, "Bethlehem Digital History Project, Philadelphia Barracks 1765," Bethlehem Pennsylvania Moravian Indian Diaries at the Bethlehem Digital History Project, February 5, 1765, accessed April 22, 2018 , http://bdhp.moravian.edu/community_records/christianindians/diaires/barracks/1765/translation65.html.

${ }^{150}$ Engel, February 5, 1765.
} 
uncertainty. But by March 20, 1765, the Moravian Indians were on the move. They left behind the barracks of Philadelphia, where the government held them for over a year. They were forgoing the safety they had in the city for the freedom they desired.

\section{Conclusion}

This chapter showed that the politics of the Pennsylvania Governor, the Assembly, and the frontier settlers forced the Moravian Indians to be captive to Philadelphia. Even though each of these factions wanted the Native Americans out of Philadelphia, the climate on the frontier was too volatile for the Moravians to leave the barracks. This volatile climate was, in large part, due to the political tensions between the city and the frontier, and, subsequently, the Governor and the Assembly. The Moravians resigned themselves to the reality that they had to wait for the approval of the government, but this resignation did not mean that the Native Americans would completely abandon their desire to leave Philadelphia. Those who wanted to leave circumvented both the Governor and the European Moravians leaders by appealing to other officials, despite the tensions it created within their community. 


\section{Maintaining Community}

Last chapter explored the actions of the Pennsylvania government, the frontier settlers, and the Moravian community. Each of these groups wanted the Native Americans out of the Philadelphia barracks, and possibly out of Pennsylvania entirely. The internal friction of the Pennsylvania government, combined with the popularity of the Paxton Boys, led to a hostile situation that meant the Moravian Indians were not safe outside of the protected barracks. The lack of freedom led to growing frustration within the Moravian congregation.

This chapter argues that during the Philadelphia internment, the community was beginning to see signs of wear, but overall was able to maintain community cohesion. The shared goals of the community were beginning to break down, but the community was strong enough to last throughout their internment. While in Philadelphia the congregation faced internal strife that threatened community cohesion until the congregation once again shared the same goals when they left the city for the frontier. This divide in the congregation was more of a strain than they had previously faced on the frontier. This chapter will focus heavily on the communal diaries to explore how the Moravians were trying to keep the community together as a Christian congregation when members in the community were at odds as to what their primary goal wassafety or freedom. First, it will look at how the Moravians maintained their community through

their shared culture and experiences. Then it will explore the hardships that that Moravians faced while they were in Philadelphia - both on Province Island and at the barracks. Next, it will examine how the goals that the Moravians shared while they were living on the frontier eroded so that some of the community sought to leave the safety of the barracks, while others within the community desired to stay. Finally, it will explain how the Moravian community came together 
again after Penn allowed them free movement from the city. While the journey to the frontier was not easy, they once again shared their primary goal - to create a new multi-ethnic village, which further strengthened their commitment to the community and to each other.

\section{The Moravian Community in Philadelphia}

\section{Maintaining Community}

One of the primary features of the Moravian community was the continued interaction and visitation within the community. These visitations helped support the shared culture that the congregation had created - the mixture of European German and Native American beliefs and traditions. Daily gatherings and spiritual visits continued to strengthen the ties of the congregation. Schmick, Grube, and their wives moved into the barracks with the Native Americans, once again proving to the Moravian Indians that regardless of the situation they were all facing it together. Services and visitations were still a priority. In fact, they probably became more important given the fact that the Native Americans were no longer living any semblance of their traditional life. The freedom of movement they had in the frontier of Pennsylvania, and even, to a lesser extent, on Province Island, was completely gone. It would have been understandable for the Moravian Indians to turn against the European Moravians based on their oppression and frustration. By prioritizing daily interactions, the European Moravians were able to monitor the spiritual health (and general frustration) of their Native American converts.

The community continued with their councils, meetings, and services daily. The congregation still separated meetings by gendered groups within the barracks, as there is evidence that the men, women, unmarried men, unmarried women, and children all met as separate groups. Even though there was a Moravian House in the city, the European missionary 
leaders decided to continue to live among their Native American converts. This was not unusual for the Moravians, once again, showing the importance of living, suffering, and worshipping as a community. This action also helped the Moravians maintain their shared experiences. Had the European Moravians lived within their assigned house, they would not have experienced the same events, trials, and pleasures as their converts. However, the Governor considered the European missionaries' dedication to the congregation unusual. On February 21, 1764, Gov. Penn went to the barracks to visit with Johan Papunhang, and Schmick saw him in the barracks. "He (Penn) was surprised that Br. Schmick lived in the barracks, he thought [Schmick lived] in the Moravian House." 151 Living with the community when they had options, and probably more comfortable options, indicates that the European Moravians were sincere about their efforts to keep the community cohesive.

During the time in the barracks there were six births, twelve baptisms, and two marriages. These vestiges of normalcy indicate that despite the hardships of the internment the Moravians were still living as a functioning community. They were getting married, having babies, and pledging their life and soul to God. The numbers for baptisms were not as high as they had been in Gnadenhütten but given the fact that they were not able to leave and interact freely with unbaptized Native Americans, twelve seems like a substantial number.

As the visits among the Moravians continued without abate, so, too, did visits from outside groups to the Moravian Indians. In Gnadenhütten these visits were mostly comprised of

151 Engel, "Bethlehem Digital History Project, Philadelphia Barracks 1764." 
other Native Americans who were friends or family with Moravian converts. On Province Island, prior to the journey toward New York, there were still some interactions between Native Americans not affiliated with the refugees and those who were under protection. In the Philadelphia barracks, conversely, there were fewer visits by Native Americans and English settlers made most of the visits. Initially Philadelphia citizens who wanted to watch the Native Americans bombarded the congregation. However, after several complaints against these visits, the guards limited them and then most of the visitors to the barracks were English colonial leaders who were supervising the treatment of the Native Americans and the provisions they had. These supervisory visits possibly gave a sense of security to the Native Americans, as they had contacts with important leaders of the city, and direct access to the Governor, who visited the barracks several times.

\section{Unwanted Visitors}

While the Philadelphia leaders had specific reasons to visit the Moravian Native Americans to discover their needs and well-being, most visitors in the first few months of their interment were general citizens of Philadelphia who visited out of curiosity. Many of the colonists came to the barracks and would often stay for evening services. It is possible that the citizens of Philadelphia, with the knowledge that their taxes helped provide for the Native Americans, felt that they had a right to observe them and their culture, as if they had purchased the right to infringe on the space of the Moravian Indians.

While the citizenry initially accosted the Moravians when they entered the city in November 1763 , by January they were eager to observe the Native Americans. It could be that in early 1764 the citizens of the city felt that the Moravian Indians were unjustly targeted. Remember, the Paxton Boys had recently attacked the Conestogas, killing twenty peaceful 
Native Americans. The government removed the Moravians from Province Island in the wake of that attack and threats to their safety. Then, in early January 1764, the Governor sent the Moravian congregation to New York; the journey was short-lived since Penn had not communicated his intensions with Colden of New York prior to the Moravians' arrival. Their subsequent return to Philadelphia ended with them guarded at the barracks near the center of the city. It is probable that the Moravian Indians had gone from a group that Philadelphia citizens considered suspicious to one that they pitied. Additionally, in early February 1764 the Paxton Boys turned their attention to the city and targeted the Native Americans who were hiding in the barracks, further indicating that the Moravian Indians needed aid.

The unwelcome incursion of settlers into Moravian space was most noticeable prior to April 1, 1764, when the European Moravians finally asked the guarding sergeant to prohibit settlers from coming into the barracks. ${ }^{152}$ Before that, hundreds of English men and women had descended upon the Moravian Indians. On January 29, 1764, only days after their arrival at the barracks, the diary stated: "The sermon was at midday. Many people from the city attended... The young people from the city nearly overran us; the watch was not in a position to keep them away." ${ }^{153}$ On February 26, the diary reported that "there were so many white people that half of the audience had to stand outside the door. They were all very attentive and quiet. Nothing charmed the people more than to hear the Indians sing." 154

\footnotetext{
152 Engel.

153 Engel.

${ }^{154}$ Engel.
} 
However, by April 1, the political divisions of the colony were making the Moravians uneasy. Moravian leaders asked the sergeant to stop allowing settlers into the barracks. But the next day, Captain Schlosser, the commanding officer of the guards, told the Moravian leaders that the Governor was pulling his company from their guard duty at the barracks. ${ }^{155}$

The removal of the guard left the Moravians vulnerable to the threats of violence, and vulnerable to the continued imposition of the Philadelphia colonists. While the immediate threat of the Paxton Boys was over, the continued pamphlet war between the Assembly supporters and Paxton Boy supporters made the Moravians cautious. The curiosity of the citizenry could easily change back to feelings of hostility — especially given the divisive rhetoric published against Native Americans and the government that continued to support them. The Provincial Minutes do not indicate the removal of the guard, but on May 5th the diary recorded that "the soldiers marched out for Lancaster and Fort Loudon. One Sergeant, with six healthy and six sick, was left here for a watch. ${ }^{156}$ Thirteen men, six of whom were sick, were not adequate to dispel the people of the city. In fact, on Sunday, May 6, 1764, Schmick wrote: "Many listeners from the city attended. In total, there were more than 1,000 people here today to see the Indians, who showed themselves very orderly and friendly." 157 This type of visitation continued, usually on Sundays when the white visitors could claim to be there for service. These interactions with the citizens probably created undue stress to the congregation. Since the citizens did not seem fully trusted

\footnotetext{
${ }^{155}$ Engel. Philadelphia publishers printed the Paxton Boys' arguments against the Assembly and Native Americans. Moravian leaders were afraid of violence toward and hate crimes against their congregation based on the publications and arguments of the Paxton Boys and their supporters.

${ }^{156}$ Engel.

${ }^{157}$ Engel.
} 
by the congregation it would be understandable that the sheer number of observers would stress the Moravian Indians. While there were approximately one hundred forty Native Americans, more than one thousand citizens of questionable motives watched them.

Illness

By May the health of many in the Native American congregation was beginning to decline. Although it cannot be proven, it is likely that the constant interaction with, and proximity to, colonists of the city caused many illnesses to spread. On June 16, Jacob Weiss visited the sick Moravian Indians and declared that three of them had pox. By June 19th the congregation was fighting against "the bloody dysentery", with many in the congregation affected. ${ }^{158}$ On June 30,1764 , due to the considerable number of deaths and illnesses, there was a special sermon "about going home [dying]". 159

The Moravians were fearful for their health and were beginning to question the European brothers. Anton, a Delaware leader, showed his support for the European brothers by calling out those who were speaking out against their decisions — going so far as to say that those who spoke out against the missionaries were speaking out against Jesus. "It is true what our wise brothers say, I know their hearts, and whoever says or thinks something against them, he speaks or thinks against the Savior, and I will have no part of it." ${ }^{\text {160 }}$ This type of admonishment concretely showed the fissures that were beginning in the community. The illnesses the Moravian Indians

${ }^{158}$ Engel, June 30, 1764.

${ }^{159}$ Engel, June 30, 1764.

${ }^{160}$ Engel, June 30, 1764. 
faced seemed to put more pressure on the small community. To the point that some within the community wanted to change their shared goal. Whereas once the shared goal seemed to be safety, now it was freedom. This was likely because the safety that the city provided was only safety from physical violence and not safety from the diseases that currently were plaguing the community. Arguably, the community would have been safer from the illnesses if they remained in the frontier.

Out of the one hundred forty Native Americans who came to Philadelphia with the European Moravians for protection, forty percent of the congregation died (fifty-six people, twenty-one children and thirty-five adults). Unlike what had happened in Gnadenhütten in 1754, the loss of these people was permanent. There was also the effect on the community psyche. In 1754 , those who decided to remain in the village, for whatever reasons, knew that those who left were leaving the community and joining another community_one full of friends and family. Additionally, that community, although removed from the Moravian village by space, still received visits and Native American contacts. The friendships between the Native American communities, Indian villages and Moravian villages, remained and continued. A decade later, however, sickness had ravaged the community.

The Moravian Indians were not the only ones who suffered from the illnesses that plagued the community. However, the European Moravians better handled the sicknesses. Both the Grubes and the Schmicks became extremely ill with fevers. The adults, however, were able to recover. Sadly, Johanna Schmick died on August 25, at only fourteen months old. These illnesses and deaths weighed heavily on the Moravians.

\section{Lack of Provisions}


When the Moravians initially arrived in Philadelphia in 1763, Penn assured that the government would care for them. The assurances of Penn, however, did little to force the city to give adequate provisions to the Moravian Indians. Despite governmental protection and promises of help, it seemed that the Philadelphia citizens were more than willing to take advantage of the Native Americans. From their initial arrival in Philadelphia until they left in 1765, the Native Americans were constantly in need of provisions and goods.

In December 1763, prior to their flight to Amboy, the Moravian Indians on Province Island were already concerned with provisions and their distribution. By December 15 they had received sixteen cords of wood, ten barrels of salted meat, five barrels of cod, over two thousand pounds of flour, and two kegs of rice. While this may seem like adequate supplies, they were responsible for feeding over one hundred and forty people. By December 19, four days later, David Zeisberger went back to Philadelphia for more provisions. When he returned the next day, he brought thirty pairs of shoes with him. On December 26, Fox came and brought twenty-five more pairs of shoes for the Moravian Indians: "they were very happy about this, since a few of them already go barefoot."161

The lack of food, clothing, and general supplies continued into the pilgrimage and return to the barracks. The Moravians relied on English charity completely for their well-being. On January 2, 1764, before their flight to New Jersey, Quakers came to Province Island and offered to take them to an island where only Quakers lived, hoping that the seclusion would protect

\footnotetext{
${ }^{161}$ Engel, “Bethlehem Digital History Project, Province Island 1764.”, December, 26, 1763.
} 
them. The Moravian leaders, however, decided to remain on Province Island under the care of the Pennsylvania government. ${ }^{162}$

The Pennsylvania government seemed to not take their charge of aid seriously. On January 5, 1764, as the Moravians were preparing to leave the city of Philadelphia due to the continued threats of violence against them, Fox gave the Moravian Indians thirty blankets to distribute. Thirty blankets are not enough to fully warm over one hundred men, women, and children on a trek through Pennsylvania during January. Once the Moravians returned to the barracks, they again faced hostile crowds and lack of goods and food. Given how quickly they had to leave the island, they even left some of their belongings behind. Upon returning to Philadelphia, they expected that they would be able to get those items back but found that many "things, particularly axes, that had been stolen."163

On February 3, Moravian leaders distributed firewood to the rooms in the barracks: "After that, a quarter of a cord of wood was distributed to every room, for which everyone was glad, as many had not a stick left to burn." ${ }^{164}$ By February 8 the diary recorded that there was little firewood left. "Our good Indians also had to endure much cold, because there is little wood to be had." 165 In fact, the Moravians did not have wood until February 17, and then not again until April 30, when Fox visited the barracks and saw that the Moravians did not have wood:

\footnotetext{
162 Engel. This decision came after the Moravians learned that the Quakers on the island did not have any access to firewood and supported themselves through fishing. However, it is doubtful that the Moravians would have lived with the Quakers anyway, since they competed for the same converts.

${ }^{163}$ Engel, "Bethlehem Digital History Project, Philadelphia Barracks 1764."

164 Engel.

165 Engel.
} 
"and when he heard and saw that the Indians lacked wood he went to the water himself, bought a couple wagons full, and brought them here." 166 While the Pennsylvania government may not have taken their charge seriously, it seemed that Fox did — at least when he was confronted with the severity of the Moravian's situation.

By autumn of 1764, lack of food, lack of proper winter clothing, and lack of wood for warmth, again confronted the Moravians. The city government gave provisions infrequently and seemingly arbitrarily. Fox would send blankets (never enough for the entire group) or food (seventy-five bushels of potatoes on November 14) but the quantity was not enough, and the infrequency of the shipments kept the Moravian Indians uncertain as to when and if they would next receive help. In October 1764 the diary recorded that many of the children had been nearly naked until Fox sent a shipment of linen, which they made into shirts for the children. ${ }^{167}$

The continued neglect of the Moravians led to uncertainty. They faced illness, death, and also had to come to term with the obvious fact that the Pennsylvania government was unwilling to provide for them in any long-term capacity, even though it was the colonial leadership that brought them to the city for protection. Without their traditional way of life, without their skills as hunters and gatherers, and without any way to support themselves, they were at a distinct disadvantage and required more help than the government was willing to give. This disadvantage coupled with the reality that their safety relied on the protection of the city. These issues all

\footnotetext{
166 Engel.

167 Engel.
} 
worked together to undermine the goals of the community. There was a question on the primary goal: safety from settler violence, or safety from illness and starvation.

There is little doubt that if the Moravian Indians were living in the frontier they would still be suffering. The years after the war left the frontier decimated. Yet, they would also have had the freedom to which they were accustomed. While they may have lacked shoes or winter clothing, they would have had ample firewood to keep their homes warm, and, arguably, more protection from the illnesses that plagued the community while they lived in Philadelphia.

\section{Native American Emotions}

Most of the diary entries did not explicitly record that the Native Americans held in Philadelphia were frustrated with their situation, and Schmick wrote those that do mention any amount of negative context, such as unhappiness or frustration. It is possible that he could have been conflating his personal feelings and opinions onto the Native Americans under his care. Yet there are instances where it seemed the Native Americans were less than fully pleased with their situation - and some cases where the record showed the growing tension in the community.

On February 24, 1764 Schmick wrote that the Native American brothers and sisters expressed their thoughts and feelings. Schmick recorded the anxious feeling of the congregation, and the desire for safety, "our poor people long for a place where they can live halfway safe again, for some people it causes some melancholy thoughts." 168 This entry recorded the fear and

\footnotetext{
${ }^{168}$ Engel.
} 
anxiety, and the resulting melancholy of the community. For years, suspicion and threats of violence, plagued the community. Philadelphia was meant to be a place where they would be under the direct protection of the government, and yet, they faced continued uncertainty and threats. Not only were they still threatened by supporters of the Paxton Boys, they also had to face the after-effects of illness and lack of provisions.

The Moravian Indians were aware of how some settlers viewed them. On March 22, 1764 when they were preparing for communion, it seemed that the Moravian Native Americans were thinking about their continued place with the European Moravians.

We want to stay with Jesus' people, if the Brethren should leave us, however, we would be very sad, since the words which the Brethren say to us from the Savior are our comfort, particularly in our current sad and difficult circumstances, when almost all people hate us and want to kill us. ${ }^{169}$

The Moravian Indians were in a difficult position. At the mercy of European settlers, it seemed that they were aware that they had to remain on their best behavior. Any actions that settlers would consider inappropriate would cause problems for the entire Moravian community. Individuals not only had to answer for their own actions, they had the entire community's reputation at stake for their individual actions. Schmick noted this on April 3, 1764 when Josua and Anton had to talk to their fellow congregants about behavior.

169 Engel. 
Because last night again two of our worst people behaved themselves badly, Josua talked with the Mahican people and Anton with the Delaware, and explained to them the kind of misfortune that could come to all of them because of a couple bad people. The ill-doers promised that they would never again do it. ${ }^{170}$

The record does not indicate what the Native Americans had done but showed the importance of maintaining respectability within the community, especially for the sake of the community's reputation. As outsiders, the Moravian Indians represented the entire community whenever they interacted with settlers. Whereas settlers had the privilege to be recognized as individuals, the Native Americans were perceived as representatives of their community. If a white person got drunk, or behaved badly, it did not reflect on the entire city-but when a Native American behaved poorly the European community saw it as indicative of their moral standing as a people. Settlers, generally, did not view the Moravian Indians as different from other Native Americans who they deemed untrustworthy or suspicious. The Moravian Indians might have been Christian, but their racial identity overrode other aspects of their lives. The ill behavior of any of the Native Americans in Philadelphia was the behavior of all the Native Americans.

Moravian leaders worried, especially, about young Moravian Indians. Young men and women were rebelling from the forced internment, and many of them made several requests to leave the safety of the city. These requests were to go hunting or visiting but the government denied them. While the diaries indicated that the young Indians were unhappy with the situation,

${ }^{170}$ Engel. 
there was little specificity in their complaints. However, they grew more frustrated as the months passed. This is unsurprising since they were unable to do almost anything except praying and studying. It could be that the young Moravians, many of whom were second generation Christians without children of their own yet, were less afraid of the turmoil of the frontier, while the older Moravians were not willing to risk their family's safety with the threats and violence that continued in the frontier. ${ }^{171}$ By the summer several diary entries recorded the continued frustration of the Moravian Indian youth. On June 21, 1764, Schmick wrote, "Our young people gave us much distress today." 172 Once again, there was no indication as to what the young people did that distressed the Moravian leaders but given the rest of the diary entries for the year, it seems that they were becoming weary of their internment.

Out of frustration, Moravian Indians began asking governmental leaders for passes to leave the city so that they could hunt. The European Moravian leaders tried to remind the Native Americans that they were only safe if they remained in the city barracks. On July 23, 1764, the European Moravian leaders held a service, after which they brought the congregation together. "We asked to know who it was who wanted to go to the wilderness. The young people said: it is us." ${ }^{173}$ Despite the warnings of Moravian elders and English governmental leaders, and despite the threats of violence on the frontier, the Moravian Indian youths were willing to risk their

${ }^{171}$ There is no indication of a gendered divide in the desire to leave the safety of the barracks. The diary entries specifically record that the young people were unhappy, not only the young men.

172 Engel, June 21, 1764.

${ }^{173}$ Engel, July 23, 1764. 
safety to leave the oppression of the barracks. The Moravian leaders tried to placate the youth, but others recognized their frustration - to the point that even Penn mentioned that they needed to remain in the barracks because he did not trust them. ${ }^{174}$

Moravian leaders were anxious to placate the Native American youth, and in November decided that maybe they needed to rearrange the rooms in the barracks to distance people from one another. ${ }^{175}$ There was no indication, however, as to which young people needed to separate, but it seemed that the Moravian leaders felt more oversight was necessary. This separation did little to fix the frustration of the Native Americans. They continued to request time out of the barracks and out of the city. While the Governor seemed to discourage their movement, Mr. William Allen, the Chief Justice of the Pennsylvania Supreme Court, freely gave out passes to Native Americans. On November 13, after visiting with Allen, he gave four Native men, without the knowledge of the European Moravian leaders, passes to return to the Susquehanna, which angered the young people. "The other young people were very upset to not go with them."176

On November 24, Schmick wrote about the worry and apprehension that the European Moravian leaders felt given Allen's actions. They continued to worry for the safety of their converts and their youth. "We heard that Sam Evans and two more of our Indians had Mr. Allen give them a pass to catch mushrooms in the area. He freely gives our people the opportunity to

\footnotetext{
${ }^{174}$ Engel, August, 14, 1764.

${ }^{175}$ Engel, November 16, 1764. gehen.“

${ }^{176}$ Engel, November 13, 1764. "Die übrignen jungen leute, wurden sehr aussezig als sie nicht durften mit
} 
move freely in the city and go everywhere, often with danger for their hearts. We are very perplexed about this, but cannot change it." 177 The Moravian leaders were obviously distraught with Allen allowing the Indians to leave the barracks and the city. This entry also indicated that the Moravian leaders were not initially aware that Sam Evans and the others were communicating with the Chief Justice, once again showing the growing divide within the community.

Yet, this pass to freedom, given to some in the community, was enough to cause more issues within the barracks. On November 27, 1764, Schmick recorded the continued frustration among the young people in the barracks. "In the evening, we discovered that more young people wanted to leave, out of annoyance, because the four Indians listed above received permission to go to the Susquehanna." ${ }^{\prime 178}$ Moravian Indian youth were frustrated with their continued forced seclusion, and they wanted to leave the security of the city and the barracks to go back onto the frontier. Also, the divisions within the community seemed to be among the young people who wanted more freedom, the older people who wanted more security, and those who moved around the European Moravian leaders to gain limited freedom of movement from the colonial government. The community within the barracks was breaking down because they now longer shared the same goals.

177 Engel, November 24, 1764.

${ }^{178}$ Engel, November 27, 1764. 


\section{Leaving Philadelphia}

On March 15, 1765, Bethlehem gave plans for the removal of the Moravians from the barracks. Moravian leadership in Bethlehem had held a conference and determined that Schmick and Zeisberger would be the missionaries that would lead the Moravian Indian congregation, "to the Susquehanna". ${ }^{179}$ The next day, Schmick and Zeisberger told the plans to both the Native Americans and Fox. With the upcoming journey, several Native Americans wanted to write a letter to the Governor thanking him for the hospitality from the past year. For the next two days Native American leaders discussed these ideas and wrote them down. On March 18, Grube recorded a draft to the Governor in the diary.

This letter draft showed several important themes. First, despite the frustration and unhappiness that the Moravian Native Americans faced during their time in the city this letter indicates that they were willing to remain diplomatic, as their words attested: "We all recognize your great love and friendship from our hearts, which you especially showed us in the recent time of war, when we were in great danger for our lives. You took us into protection and defended us against our enemies, so that we could live here in peace..." 180 Grube wrote their words, but their gratefulness did not seem false. While they faced frustration and immobility in

the city, perhaps the destruction of the frontier forced them to view their situation differently. ${ }^{181}$

\footnotetext{
179 Engel, "Bethlehem Digital History Project, Philadelphia Barracks 1765," March 15, 1765.

180 Engel, March 18, 1765.

181 Josua described this destruction after his trip to the Susquehanna in December 1764.
} 
Second, they recognized the role that the government played in their safety and thanked them for their aid during the massive smallpox outbreak that attacked their congregation the year prior. "In our sickness you have nursed us and had our dead buried."182

Third, they thanked the government in advance for grain, writing that, "to our joy, we have also heard that you will further care for us with grain, until we can eat our own corn." ${ }^{183}$ It is possible that this was true, but it is also possible that it was a maneuver. By thanking Penn in advance, it could be that the Moravian Indians were acting on a rumor, especially since the wording indicated that this was not an agreement that the Moravians and Penn had finalized. Instead they "heard" that Penn would provide them with grain. It is possible that by thanking Penn in advance they hoped to finalize that agreement. If Penn then refused to help them with the corn, he would disappoint the Native Americans who had been so grateful for the aid.

Fourth, the Moravian Indians seemed to use more traditional Native American diplomacy. Their use of paternal language, by telling the Governor he "cared for us like a father with food and clothing" tied into Native American diplomacy and alliance traditions. ${ }^{184}$ The use of the term "father" indicated that the Native Americans acknowledged the authority of the Governor, but less than if they had referred to him as "uncle". ${ }^{185}$ This was compounded with the

\footnotetext{
182 Engel, March 18, 1765.

${ }^{183}$ Engel, March 18, 1765.

${ }^{184}$ Engel, March 18, 1765.

${ }^{185}$ White, 36-40.
} 
promise to "remain true friends of the English" as well as tell other Native Americans about how well they were treated in the city.

Fifth, the Native Americans asked for hunting supplies. "One more thing we ask, that you will give us some powder and lead for our long and difficult journey, so that we can shoot something for our maintenance." 186 If the Governor was willing to supply them with lead and powder, it would show that, despite Penn admitting that he did not trust all the young people, he trusted the Moravian Indians in general. Unlike with the corn, they did not claim that they already heard he would do this. Instead they asked him, directly after swearing their alliance, for the supplies. This may have been a calculated plea. If Penn believed their alliance and their gratitude, he would be willing to provide them with the supplies they would need on their journey from the barracks.

Johan Papunhang, Josua Senior, Anton, and Sem Evans signed both the final letter to the Governor and the draft. While Papunhang and Evans were not full members of the congregation, they were influential Native Americans with strong connections to the community. Papunhang was baptized, while Evans was not. Josua Senior was a Mohican congregational leader, and Anton was his Delaware equivalent. Thus, it seemed that this communication represented all the factions within the barracks.

On March 19, 1765 Schmick and Josua Senior went to Fox and thanked him, specifically, for the care and aid he gave to the Moravian Indians during their time in Philadelphia. "With wet

${ }^{186}$ Engel, March 18, 1765. 
eyes he said: I have done what I could because I knew these were innocent people. What concerns you, however, I would have gladly done more, but had no orders for it."187 This important piece of information showed that Fox was limited in the amount of help he was able to give to the Moravian Indians.

Based on the diaries and the Provincial Minutes it is impossible to witness the entire picture. We cannot determine if it was Penn who failed to allow more aid, if Penn requested aid, but the Assembly (perhaps out of animosity toward Penn) refused the request, if Penn and the Assembly both overlooked the actual needs of the Native Americans and focused on more immediate concerns, or if Fox failed to press his superiors on behalf of the Moravian Indians. Regardless of the reasons behind the neglect, here Fox was indicating that he wished he would have been a better ally and advocate for the Native Americans who had been under his charge.

On March 20, 1765 the Moravian Indians ended their internment in Philadelphia.

At midday, the departure occurred. Various brothers and sisters from the city visited us, in order to be present at our withdrawal. Eight wagons were loaded with baggage, women, and children. There was a great difference between our arrival and our departure. At the former there were surrounded by several thousand people, and at the latter it all went quietly, so that few people took notice of us. ${ }^{188}$

${ }^{187}$ Engel, "Bethlehem Digital History Project, Philadelphia Barracks 1765," March 19, 1765.

${ }^{188}$ Engel, March 20, 1765. 
It is unsurprising that the departure of the Moravian Indians during a time of relative peace would be less chaotic than the arrival of the same Native Americans during a time of war. Also, in 1763 when the Moravians had arrived, the air of suspicion was heavy around the congregation. The Paxton Boys had been terrorizing Native Americans on the frontier, and the Moravian Indians had not been known to the citizens of Philadelphia. The people of Philadelphia had been more likely to succumb to suspicion and rumors than to act with hospitality toward the Native Americans who had suddenly arrived in their city. Additionally, the government's initial treatment of the Moravian Indians (holding them outside of the barracks for hours with a throng of unfriendly people around them) had done little to assure the city's population that these people were worthy of protection.

Conversely, in 1765 when the Moravians left the war was effectively over. While there had been some dramatic interactions with the Moravian internment-like when the Paxton Boys came to possibly attack the barracks — most of the time spent on Province Island and at the barracks was relatively peaceful, especially from the perspective of someone outside of the Moravian community. Within the community there were grumblings of frustration, but it is probable that the average person of the city was unaware of the frustration and impatience of the Moravians. The interactions the city had with the Moravian congregation made the Indians seem less exotic and frightening. Instead, the city became used to the Moravian Indians living in their midst, so there was less reason to observe them as they left. 
When the community left, the group marched for days until they reached Nain. ${ }^{189}$ The diary entry from February 5, 1765 mentioned animosity around the village and indicated that they would not be stopping to stay there. Yet, on March 22, the Moravian Indians reached Nain and remained until April 3. While they were in Nain, they lived in their own small houses. ${ }^{190}$ This must have been a distinct departure from the communal living of the barracks. Many of the Moravian Indians had returned to where they had been living from 1758 to 1763 .

On April 3, 1765 the Moravian Indian community left their homes in Nain "not without pain" to trek farther north to the Susquehanna River Valley. ${ }^{191}$ They first stopped in Bethlehem to see the Brethren there and say their farewells. "Many tears were spilled on both sides."192

\section{From Nain to the Susquehanna}

At some point, Moravian leadership decided that the Moravian Indians would do better in the Susquehanna River Valley than near Bethlehem. This may have been because by 1765 Bethlehem was no longer firmly on the frontier. The influx of European settlers surrounding the town would not have given the Native American converts the freedom in the wilderness that they desired.

\footnotetext{
${ }^{189}$ Engel, March 20-22, 1765.

${ }^{190}$ Engel, March 22, 1765.

${ }^{191}$ Engel, April 3, 1765.

192 Engel, April 3, 1765.
} 
Rachel Wheeler and Thomas Hahn-Bruckart wrote about the journey from Nain to Friedenshütten, positioning it into the scholarship as "one stage on a long, slow trail of tears."193 Their article translated the congregational diaries from April 3 to May 24, 1765 in their entirety, and gave brief background information on the political and cultural events we have discussed. Their primary thesis - that the forced migration of Native Americans that happened later in the eighteenth and nineteenth centuries directly connects to this five-week journey from Nain to Friedenshütten — is unconvincing for reasons outlined below.

Pennsylvania's reluctance to adequately care for the Native Americans in their care, and its multiple efforts to remove the Moravian Indians from the Pennsylvania frontier may seem to confirm the Wheeler-Hahn-Bruckart thesis. However, the movement of the Moravian Indians from Philadelphia, back to Nain, and then on to Friedenshütten, was not against the wishes of the Native Americans. In fact, they, as a congregation, petitioned the government for months to leave the city. They were leaving for villages that may not have traditionally been theirs, but on land that was still familiar to them. They were returning to lives where they could live and farm with other, non-baptized kin and friends.

From April 3 to May 9, 1765 the Moravian Indian congregation travelled from Nain to near the remains of Wyalusing, which they converted in to a missionary town and renamed Friedenshütten. The Moravian Indians' journey to their final village in Pennsylvania (they

${ }^{193}$ Rachel Wheeler and Thomas Hahn-Bruckart, "On an Eighteenth-Century Trail of Tears: The Travel Diary of Johann Jacob Schmick of the Moravian Indian Congregation's Journey to the Susquehanna, 1765," Journal of Moravian History 15, no. 1 (2015): 55. 
moved again into the Ohio River Valley in the early 1770s) was not an easy trek. The first few days seemed fortuitous, but by April 15, 1765, the Moravians were fighting terrain, weather, and hunger. The terrain was not conducive for easy travel. There were two mountain ranges to cross, the Small Blue and Large Blue Mountains, part of the eastern Appalachian Mountains. Additionally, there were rivers and creeks to ford. There were many instances where the more able-bodied people would forge ahead to clear the path or begin the camp for the day before they would return to help those who were not as physically able. "After the morning devotions, most carried their belongings four more miles, and as it grew mountainous and quite rocky everyone went back and forth to help the others carry their loads and bring them together then and there." 194 The community, despite the physical hardships, continued to work together for the betterment of the congregation.

The weather did not help when it came to travel, especially when it came to the rivers and creeks. Spring in Pennsylvania can be temperamental, bringing rain and snow even late into the season. In April 1765 there were rains that caused rivers and creeks to flood, costing the congregation several days of travel. The men were unable to create rafts or bridges to cross the creek due to the swift current. ${ }^{195}$ The hardships of the journey were not always events that teamwork could overcome. Instances like the one above, the futile work of men attempting to create a path over a flooded creek, could not rely on merely communal cooperation to succeed.

\footnotetext{
194 Wheeler and Hahn-Bruckart, 62.

195 Wheeler and Hahn-Bruckart, 65.
} 
Instead, the congregation also had to abide in patience, waiting for the flooding to subside, and deciding their next move. In this instance they decided to dig out a canoe and the next day they proceeded to shuttle the congregation over the flooded creek, a task that took over three hours. ${ }^{196}$

Not only was the external physical aspect of the journey tiring for the men and women of the congregation, but, internally, the Moravian Indians were fighting against lack of food and other provisions. The diary consistently recorded that there was little food, and people, both congregants and visiting Native Americans, were going hungry. They relied on foraging, and "to assuage and satisfy them somewhat, they tapped some chestnut trees and gave them the sweet syrup to lick." 197

Penn, at least, followed through on the aid the Moravian Indians had implied in the letter they sent him in March. On April 5, when the group was a little over a mile from Wechquetank (the mission town that Grube had headed prior to the violence of 1763), they received their first delivery of flour from the Pennsylvania government. ${ }^{198}$ Yet, the flour was delivered incrementally and with the congregation on the move, minus the days when they were forced to wait for the flooding of creeks and rivers to subside, most of the flour was miles behind them for the entire journey. This meant that they had to continuously send young men back to fetch it. ${ }^{199}$ Regardless of the aid Penn gave in the allowance of flour, the congregation quickly went through their allotment, and by May 2, 1765 they were out of flour.

\footnotetext{
196 Wheeler and Hahn-Bruckart, 66.

197 Wheeler and Hahn-Bruckart, 74.

198 Wheeler and Hahn-Bruckart, 58.

199 Wheeler and Hahn-Bruckart, 66, 72.
} 
To supplement their rations, the Native Americans again relied on their hunting and foraging skills. Penn must have acquiesced and provided the Native Americans with powder and lead, as there were several hunting expeditions that the men went on. Once they reached the abandoned village of Wyalusing, they began to repair the huts and forage for potatoes and other food. On May 10, due to the lack of provisions, and the fact that they finished the flour days prior, the community decided to send several men on a four-day hunt. The hunt was successful, and the congregation had five deer and one bear when the hunters returned on May $13 .{ }^{200}$ On the 14th the congregation began planting.

\section{Community Commitment}

The community maintained their cohesion while they were on the move. The stresses that they continued to face: terrain, weather, and lack of provisions, were not unknown to them as a community. Yet, the journey of the congregation to their new home showed the commitment that the Moravians had for their mission. Despite the tension of the trek and the physical hardships they endured, they remained cooperative and compassionate with each other. They proved this cooperation multiple times in their five-week journey and the subsequent rebuilding of the village. The congregation seemed to recognize that the success of the community demanded that they cooperate and care for one another. Whether this was though hunting and gathering

\footnotetext{
${ }^{200}$ Wheeler and Hahn-Bruckart, 79-82.
} 
provisions, or through sharing food when it was scarce, the community showed their commitment.

Often, the most physically capable of the congregation went ahead to make the way easier for those who were not as physically able. ${ }^{201}$ Not only did this help those who were behind, the most able also helped by returning several times to help carry the supplies and the goods of the least physically capable. Instead of going ahead and merely waiting for the less able-bodied to reach them, the able retuned and helped the congregation time and again.

This type of compassion and help did not only happen due to the terrain. In fact, several diary entries recorded the congregation shared the last of their flour and provisions, "they shared what little they had with the others out of love, and the Savior blessed it in such way that all were amazed that they had enough to eat, and thanked the Savior sincerely."202 This compassion, once again, exemplified the commitment of the European Moravians to positive interactions with Native Americans, possibly hoping that by sharing the congregational provisions they would reach new converts. It also showed the willingness of the Moravian Indians to share with other Native Americans who were also suffering.

The community recognized, as it had in Gnadenhütten and Philadelphia, that their success lay in the cooperation of the entire congregation for their survival. Despite the disagreements that

201 Wheeler and Hahn-Bruckart, 66.

202 Wheeler and Hahn-Bruckart, 66. This entry clearly corresponds to the Gospel stories of Jesus feeding the multitudes. After being given minimal amount of bread and fish, Jesus shared the food and, miraculously, it was able to satisfy thousands. Matthew 14:13-21, Matthew 15:32-39, NIV. The Moravian ministers, of course, would have known of this miracle and would possibly have taken enough rationing as evidence of God's favor-or as propaganda for the other Moravian communities that would receive the summarized diaries. 
had plagued them in the barracks, it seemed that once they were out of that stressful situation, they returned to the cohesive community they had worked hard to create. Once they reached Wyalusing, and began building near the destroyed Delaware town, they wasted no time in preparing fields that had lain fallow for years, readying them for planting.

Even before the completion of their journey, the Moravians were implementing the normal schedule of their daily life as a congregation. While there may have been some setbacks that disrupted the schedule for some of the congregants - specifically the men who ranged ahead or hunted - the leaders of the congregation, both European and Native American, maintained daily services, read the watchword, and visited with members to ensure that their faith remained strong. These visitations, as noted in chapter two, solidified the connection between the members of the congregation.

Additionally, once the Pennsylvania government released the congregation from Philadelphia, Native Americans who were not members of the congregation visited them on the journey. These visitors would often stay to listen to worship services, and, in one case, three families decided to remain with the Moravians and continue to Wyalusing. ${ }^{203}$ Some of the American Indian visitors knew who the Moravians were and had interactions with them prior to their internment in Philadelphia. "Six Indian strangers came to us and were happy to see (us and) our people as two of them had sometimes visited Nain, and had grown fond of us." ${ }^{204}$ The

\footnotetext{
203 Wheeler and Hahn-Bruckart, 76.

204 Wheeler and Hahn-Bruckart, 74.
} 
Moravians were back to being a presence in the lives of those Native Americans who, while not members of the congregation, were friendly to the Moravians and their teachings.

On May 15, 1765 the congregation sent a letter and string of wampum to the Iroquois which detailed the prior year in Philadelphia as well as their location and a request. They wanted to ensure that the location of their chosen village, near but not directly at the Munsee Delaware village of Wyalusing, was agreeable to the Iroquois, who still held control of the area. They also requested that the Iroquois permit at least one European Moravian brother to reside with the Native Americans at the village. ${ }^{205}$

These requests showed many themes. First, the Moravian Indians told the Iroquois about how well Pennsylvania's government treated them during their stay in Philadelphia. The diary entry gave a brief record of the message saying that: "how for more than a year they were protected by the Pennsylvania government from the hostile white people, for which they had cause to be grateful and appreciate." 206 The letter to the Governor from Josua, Johan Papunhang, Anton, and Sem Evans in March promised that they would tell other Native Americans about how well they were treated by the Pennsylvania government. However, this one sentence did not fully convey their time in the city; instead it glossed over many of the problems, but it fulfilled the promise of the congregation.

\footnotetext{
205 Wheeler and Hahn-Bruckart, 83.

206 Wheeler and Hahn-Bruckart, 82.
} 
Second, the Moravian Indians, under the suggestion of the Pennsylvania government, were asking the Iroquois as to where they should stay, "until they receive an answer from the Six Nations as their Uncles about whether they should settle here or in another place along the Susquehanna." ${ }^{207}$ This showed that not only did the Moravian Indians recognize the power of the Iroquois on the Upper Susquehanna, but that the Pennsylvania government did as well.

Third, the Moravian Indians asked the Iroquois to allow a European Moravian brother to remain in the new village with them to continue to teach them about God and Jesus. This third point reflected the entire mission of this congregation — to act as a Christian community regardless of tribal or ethnic affiliation. Not only did they request a brother, they also indicated that without a European Moravian there to guide them they would revert to violence and animosity. ${ }^{208}$ It is possible that the Moravian Indians wanted to ensure that the Iroquois would grant their petition by warning them that without this allowance their small community would not survive. It is also possible that the time spent in the barracks caused more tension among that Delaware and Mohicans than the diary expressed. Yet the diary continuously placed the leaders of the different tribes together, as they made decisions for the multi-ethnic community. For instance, Josua Senior, (Mohican), Johan Papunhang (Munsee Delaware), Anton (Delaware), and Sem Evans (Delaware) all signed the March letter to the Governor. It is true that by this point there were more Delaware than Mohican, but they both played an important part in the

\footnotetext{
207 Wheeler and Hahn-Bruckart, 83.

${ }^{208}$ Wheeler and Hahn-Bruckart, 83.
} 
community. Additionally, while interred in the barracks, Josua Junior married the daughter of Papunhang, effectively allying the two families and tribes further. ${ }^{209}$ Thus, it seemed that the congregation was trying to force the Iroquois to allow a brother to remain in the new village with them, by claiming that without the Moravian supervision the community would fail.

In May 1765, the Moravian Indian congregation, many of whom were survivors of the destruction of Gnadenhütten, the Seven Years' War, and forced internment in Philadelphia, broke ground on a new village. Friedenshütten, as they called it, was near the village of Wyalusing. ${ }^{210}$ The Moravian Indians and their preachers, including the Schmicks, lived there peacefully for six years until the congregation moved again, farther west to the Ohio country.

\section{Conclusion}

In conclusion, this chapter argued that internment, internal frustration, and disagreements on shared community goals challenged the cohesion of the Moravian congregation. The Moravians used the community-building strategies they began in Gnadenhütten to maintain their community. These strategies proved difficult in the barracks where they faced frustration and discontent but eased once they regained their freedom and journeyed to the Susquehanna Valley. They continued to interact with cooperation and compassion. In the barracks they had been a community of prisoners, but then they became a community of free men and women who chose

${ }^{209}$ Wheeler and Hahn-Bruckart, 53.

${ }^{210}$ Katherine M Faull, "From Friedenshütten to Wyoming: Johannes Ettwein's Map of the Upper Susquehanna (1768) and an Account of His Journey," Journal of Moravian History 11 (2011): fig. 1. This figure shows that the new village of Friedenshütten was not directly on the remains of Wyalusing. 
where to live and what to do with their lives again. Even with this regained freedom they still had to position themselves in the larger frontier dynamics. They petitioned the Governor and the Iroquois and were able to live peacefully for several more years - until the eventual encroachment of settlers continued to push them west. 


\section{Conclusion}

The Moravians, both European and Indian, created a community that withstood the violence and the pressures of the Seven Years' War. By uniting marginalized groups for mutual benefit, they created a synthesized community, a middle ground, surrounded by those who wanted domination rather than compromise. From 1753 to 1765 the Moravian community that began in Gnadenhütten faced obstacles that threatened community cohesion. The imperial politics of the frontier pressured the pacifists into action. It is possible that the non-imperial goals of the Moravians allowed them to create a cohesive community that would not have been as successful as English or French counterparts. Moravian leaders were able to maintain relative political independence; imperial powers may have pushed them into action, but their goals were not goals that an empire imposed upon them.

When the community tried to remain removed from the frontier pressures to move in 1755, Native American raiders destroyed the Moravian village. The community, however, did not disappear. The community adapted and became connected by their shared experiences, culture, and goals. Externally, the community faced violence of the Seven Years' War, retaliation from the Iroquois, forced internment in Philadelphia, suspicion and threats from the Paxton Boys, and mistrust from the Pennsylvania government. Internally, the community faced the migration of eighty-five people in 1754, the movement of villages during times of war, deaths of forty percent of the congregation during their internment in Philadelphia, and the frustration and test to the community in 1765 . However, despite these obstacles the Moravian community continued in eastern Pennsylvania at Friedenshütten until 1772, when encroaching settlers pushed them into the Ohio River Valley, settling in Gnadenhütten, Ohio. 
Part One focused on the communities of Meniolagomekah and Gnadenhütten and how they created a community during a politically divisive time. The Moravians, despite wanting to remain outside of the political fray, had to interact politically with the English and the Iroquois, who were trying to remove the Native Americans from their traditional land on the frontier and into areas where they could control the Moravian Indians more easily. Despite these attempts by the larger powers to use political tensions to tear apart the smaller communities, the Moravians used shared culture, experiences, and goals to create a cohesive community that was able to withstand those attempts. This community was based on mutual good, as both groups were marginalized on the Pennsylvania frontier. The cohesion of the community led to Moravian Indians defying the wishes of the Iroquois and remaining in Gnadenhütten. This defiance, however, led to the destruction of the village and the death of nearly a dozen German Moravians. Part Two followed the Gnadenhütten community into the village of Nain and, subsequently, to Philadelphia where Penn placed them under protection. The Moravian Indians were as endangered after the war as they were prior to and during the war. In fact, it was not until the war was over that the Moravian Indians petitioned the government for aid, showing that they needed help after the war from suspicious settlers who were targeting them. The politics of the frontier led to an English populace that was suspicious of the German Moravians and their Native American converts. The Quaker Assembly's compassion toward Native Americans, coupled with their devotion to pacifism led to discontent among the frontier settlers, that the Governor could manipulate for political gain. The Pennsylvania government created a situation where the citizens of Philadelphia did not want the Moravian Indians in the city, but the Moravians were also unable to leave the city because of the racial and political tensions of the frontier. These tensions, combined with some questionable preferential treatment toward certain 
Indian leaders from Pennsylvania colonial leaders, led to frustrations and tensions within the Indians at the barracks. These internal tensions led to stress on the community goals - some (mostly older) native Americans wanted to remain in the safety of Philadelphia while others (mostly younger) Native Americans wanted the freedom of the frontier. After the government allowed the Moravians to leave the barracks, those internal stressors diminished, and the community once again shared goals.

The communal diaries and Provincial Minutes of Pennsylvania showed the complex situation in which the Moravian Indians found themselves. They went from a situation where they were in control of their decisions to one where they were subject to the decisions of the Pennsylvania government, following the trajectory that DuVal and White mapped out from native ground, middle ground, to American (in this case, Pennsylvanian) ground. The community was able to maintain the connections they made despite the growing racial divide that Merritt and Silver explored. This was a divide that pulled the Moravians from their traditional lands and threatened, but failed, to destroy the community.

These diaries proved that the Moravian community was able to remain cohesive, regardless of the setbacks they faced. The Moravians, whether European or Native American, were still living, working, suffering, and worshipping together. A list of Indian families from Friedenshütten in 1772 showed that many of the Indians who were living in Friedenshütten were among those who had been active in the Moravian community since Gnadenhütten, including Moses and Josua, two Mohican men. The list also included Johann Papunhang and Sem Evans, two of the Delaware men from Wyalusing that had moved into the barracks with the 
Moravians. $^{211}$ This showed that those men now tied their futures to the futures of the Moravian community.

In Friedenshütten, the Moravians continued to live as they had in Gnadenhütten and Nain. They visited with one another, worshipped together, and met with unbaptized Indians, despite the racial tensions that increased after the war. ${ }^{212}$ For nearly eight years, they lived at the village in a multi-ethnic community based on shared experiences, culture, and goals. The Moravians, because of the commitment to the community, created a middle ground that went with them, from the Pennsylvania frontier to the barracks of Philadelphia. The congregants worked together to create a synthesized community that helped support them during trying times. Location, ethnicity, politics, or race did not define this community. Others recognized it based on its faith. While the Seven Years' War solidified racism in Pennsylvania, the Moravians worked outside of those parameters. Settlers targeted European Moravians regardless of their 'white' body, and Native Americans targeted Moravian Indians regardless of their 'Indianness'. Identities were forming, but the Moravians, due in large part to their devotion to their Native American missions, remained outside of the European unit, while Moravian Indians, due to their faith, remained outside of the Indian.

Research on this project could continue by adding in other parties' letters and diaries, as well as deepening the interactions between the Moravians and outside players. Specifically, by exploring the letters of Sir William Johnson and Benjamin Franklin. It would also be useful to

${ }^{211}$ MAB, MissInd 1.08.131.10.5.

${ }^{212}$ MAB, MissInd 1.08.131.3 
find any personal letters of Joseph Fox, the man who supervised the internment of the Moravians during their time in Philadelphia. Additionally, by recognizing the key dates of the community, it could prove useful to explore other newspapers from the period to gather more information based on other perspectives.

Johnson, as the British Superintendent of Indian Affairs, played a significant role in Indian relations and interacted with some of the most important Native Americans and colonial/early American political leaders. His letters would help give insight into how his policies directly affected the Moravian Indians. It is possible that they could also shine some light on the specific Native American actors. While the diaries and the Provincial Minutes broadly recorded interactions with Iroquois, Delaware, etc., it is probable that the community was interacting more specifically with the Seneca, the Iroquois Confederacy's westernmost tribe. However, given the limited information of the diaries and the minutes, it is difficult to prove. Franklin, as a Pennsylvania Assemblyman, was directly involved in the policies and politics of the time. He was also the man who met the Paxton Boys on their march to the city of Philadelphia. It is well known that Franklin held disdain for Germans, but by reading his letters we could see whether that disdain translated to his politics, especially when the government interred the Moravians in the city. Fox, as Provincial Secretary, interacted regularly with the Moravians when the government brought the congregation to Philadelphia. He helped the Moravians with rations and supplies while they were on Province Island and after the aborted trip to Johnson's lands in January 1764, opened the barracks to them. Fox owned the barrack's lands, which effectively made him their overseer. Additionally, when the Moravians were leaving in March 1765, Fox told the congregation that he wished he could have done more for 
them during their internment. It would be interesting to read his letters to see if the province held him back, or if these words were platitudes.

The next steps for research outside of the dissertation's parameters seem to be to continue with the community in Friedenshütten. Some historians claim that tribal animosities between the Delaware and the Mohicans continued in the new village and led to community breakdown. ${ }^{213}$ However, the diaries need extensively explored to determine the validity of that statement. After settlers pushed out the mission from Friedenshütten in 1772, Schmick and Heckewelder went with the congregation into Ohio and founded the village of Gnadenhütten. Bishop Heil called Schmick back to Letitz, Pa in 1777, and Schmick died in 1778. The Ohio village of Gnadenhütten met an even bloodier fate than its Pennsylvania namesake. In 1782 militia volunteers from southwestern Pennsylvania attacked and killed ninety Moravian Indians. ${ }^{214}$ Yet, each of these mission villages have their communal diaries, and scholars have researched few indepth.

Another project that could use this research as a backbone would be a comparative analysis of other missionary villages that attempted to create community cohesion. By examining New Spain, New France, Puritans, Quakers, Methodists, Anglicans, and Lutherans, research could expand on the creation of religious or faith-based communities and determine how the Moravians compared to these other groups. The letters and diary of John Wesley, one of the

\footnotetext{
${ }^{213}$ Amy C. Schutt, "Tribal Identity in the Moravian Missions on the Susquehanna," Pennsylvania History: A Journal of Mid-Atlantic Studies 66, no. 3 (1999): 378-98.

${ }^{214} \mathrm{An}$ interesting project for me would be to follow these volunteers and discover their motives. I am from Washington, Pennsylvania, where many of the militia members came from.
} 
founders of Methodism, and letters from other prominent evangelicals would be helpful to determine if other places and other groups used tactics like the Moravians' to build cohesion within their communities.

It could also be beneficial to take the three community building themes and do a comparative study of other Moravian mission villages worldwide. Moravians had missions throughout the world, and by looking at the time and place we could see if the tactics used during the violence of the Seven Years' War were used in other missions to create village cohesion. It would be interesting to see how these tactics fed into the larger Moravian world. By creating community cohesion in the missions, they were attempting cohesion worldwide.

Another project could examine if the Moravians were able to remain neutral when the Revolutionary War began. As non-imperial actors in the colonies, did the Moravians maintain political neutrality during another time of war? Instead of imperial battles, the Revolutionary War must have addressed concerns that even the Moravians felt. It would be interesting to examine Schmick's community, the community of this project, and see what actions they took during the Revolutionary period. By looking at the community diaries and letters among church leaders we could probably determine if they attempted neutrality, helped, or hindered the Patriots' cause. We could also see the official stance of the Church and the actions of the people on the ground. Were the missionaries stationed in the periphery choosing political sides without the knowledge or approval of the church leaders? The community diaries of the Moravians are under-utilized and full of information to discover and analyze.

Overall, this dissertation began as a research project that was meant to examine the role of violence in relation to cultural negotiations and community building. While aspects of the initial project changed, the diaries and sources exemplified a community that they created and 
maintained diligently. Two marginalized groups came together during a time of violence to create a community that was mutually beneficial. The violence of the $1750 \mathrm{~s}$ and $1760 \mathrm{~s}$, and the political maneuverings of Empires and colonists, did not hinder this multi-ethnic community, which continued to worship and live together into the nineteenth century. 


\section{Archival Sources}

MAB. Moravian Archives Bethlehem. Bethlehem, Pennsylvania. MissInd 1.08.131.1 (April-May 1765 at Friedenshütten)

MissInd 1.11.118.1 (Diary by Schmick, January-June 30, 1754 at Gnadenhütten)

MissInd 1.11.118.2 (Diary by Schmick, July-December 31, 1754 at Gnadenhütten)

MissInd 1.11.118.5 (Letters by Seidel, Schmick, others., 1754-1755)

MissInd 1.11.118.6 (Letters by Schmick, Mack, others., 1755)

MissInd 1.18.122.3 (Diary by Büninger and Schmick, 1753 at Meniolagomekah)

MissInd 1.20.125.2 (Diaries, Memorabilia by Schmick, Mack, others. 1759-1760 at Nain)

MissInd 1.20.125.3 (Diary, Memorabilia by Schmick, 1762-1763 at Nain)

MissInd 1.26.127.3 (Diary by Grube and Schmick, March 1-October 29, 1764 at Philadelphia)

MissInd 1.26.127.5 (Petitions, letters. 1763-1765 at Philadelphia)

MissInd 1.34.124.7 (Miscellaneous documents, 1763 at Wechquetank)

MPCP. Minutes of the Provincial Council of Pennsylvania. Vols. 4-9. Harrisburg, Pennsylvania, 1851.

\section{Online Primary Sources}

“1763 Letter from Peter Boehler to Governor James Hamilton.” Bethlehem Digital History Project. Accessed June 20, 2018.

http://bdhp.moravian.edu/personal_papers/letters/indians/1763boehler.html.

“1764 Letter from Lewis Weiss to Frederick Marshall.” Bethlehem Digital History Project. Accessed April 28, 2018. http://bdhp.moravian.edu/personal_papers/letters/indians/1764weisssource1.html.

"1765 Address of the Christian Indians to Governor John Penn." Bethlehem Digital History Project. Accessed April 22, 2018.

http://bdhp.moravian.edu/personal_papers/letters/indians/1765indianaddress.html.

Accessible Archives. The Pennsylvania Gazette. Philadelphia, Pa: B. Franklin and H. Meredith, 1729.

“Attack on Gnadenhütten.” The Pennsylvania Gazette. November 27, 1755. Accessible Archives.

"Bethlehem Diary, November 16, 1763." Bethlehem Pennsylvania Moravian Indian Diaries at the Bethlehem Digital History Project. Accessed April 22, 2018. http://bdhp.moravian.edu/community_records/bethlehem_diary/16nov1763.html.

"Bethlehem Digital History Project, Province Island Diary Source 1." Bethlehem Pennsylvania Moravian Indian Diaries at the Bethlehem Digital History Project. Accessed April 20, 2018.

http://bdhp.moravian.edu/community_records/christianindians/provincediary/provincesou rcel.html. 
"Colonel Anderson and the New Jersey Militia." The Pennsylvania Gazette. December 4, 1755. Accessible Archives.

Engel, Katherine Carte. "Bethlehem Digital History Project, Amboy 1764.” Bethlehem Pennsylvania Moravian Indian Diaries at the Bethlehem Digital History Project. Accessed April 20, 2018. http://bdhp.moravian.edu/community_records/christianindians/diaires/amboy/1764amboy .html.

_. "Bethlehem Digital History Project, Philadelphia Barracks 1764." Bethlehem Pennsylvania Moravian Indian Diaries at the Bethlehem Digital History Project. Accessed April 22, 2018. http://bdhp.moravian.edu/community_records/christianindians/diaires/barracks/1764/tran slation64.html. . "Bethlehem Digital History Project, Philadelphia Barracks 1765." Bethlehem Pennsylvania Moravian Indian Diaries at the Bethlehem Digital History Project. Accessed April 22, 2018. http://bdhp.moravian.edu/community_records/christianindians/diaires/barracks/1765/tran slation65.html.

. "Bethlehem Digital History Project, Province Island 1764." Bethlehem Pennsylvania Moravian Indian Diaries at the Bethlehem Digital History Project. Accessed April 20, 2018.

http://bdhp.moravian.edu/community_records/christianindians/provincediary/1764provin ce.html.

. "Bethlehem Digital History Project, Travel Diary 1764." Bethlehem Pennsylvania Moravian Indian Diaries at the Bethlehem Digital History Project. Accessed April 22, 2018.

http://bdhp.moravian.edu/community_records/christianindians/diaires/travel/1764travel.h tml.

“Moses Tatamy Affidavit." Pennsylvania Gazette. December 4, 1755. Accessible Archives.

\section{Bibliography}

Anderson, Fred. Crucible of War: The Seven Years' War and the Fate of Empire in British North America, 1754-1766. Random House LLC, 2007.

Bartel, Klaus J. "German and the Germans at the Time of the American Revolution." The Modern Language Journal 60, no. 3 (March 1, 1976): 96-100.

Calloway, Colin G. New Worlds for All: Indians, Europeans, and the Remaking of Early America. JHU Press, 2013.

- The Scratch of a Pen: 1763 and the Transformation of North America. New York: Oxford University Press, 2006. . The Shawnees and the War for America. Penguin, 2007.

Camenzind, Krista. "From the Holy Experiment to the Paxton Boys: Violence, Manhood, and Race in Pennsylvania during the Seven Years' War," 2002.

Case, Clarence Marsh. The Social Psychology of Passive Resistance. University of WisconsinMadison, 1915. 
Cronon, William. Changes in the Land: Indians, Colonists, and the Ecology of New England. Macmillan, 2011.

Day, Sherman. Historical Collections of the State of Pennsylvania: Containing a Copious Selection of the Most Interesting Facts, Traditions, Biographical Sketches, Anecdotes, Etc., Relating to Its History and Antiquities, Both General and Local, with Topographical Descriptions of Every County and All the Larger Towns in the State. G. W. Gorton, 1843.

Drake, Samuel Gardner. Biography and History of the Indians of North America, from Its First Discovery to the Present Time: Comprising Details in the Lives of All the Most Distinguished Chiefs and Counsellors, Exploits of Warriors, and the Celebrated Speeches of Their Orators; Also a History of the Wars, Massacres and Depredations, as Well as the Wrongs ... Which the Europeans and Their Descendants Have Done Them; with an Account of Their Antiquities, Manners and Customs, Religion and Laws; Likewise Exhibiting an Analysis of the ... Authors Who Have Written Upon ... the First Peopling of America. Antiquarian Institute, 1837.

Dunbar, John R. The Paxton Papers. Springer Science \& Business Media, 2012.

DuVal, Kathleen. The Native Ground: Indians and Colonists in the Heart of the Continent. University of Pennsylvania Press, 2011.

Engels, Jeremy. "“Equipped for Murder': The Paxton Boys and" the Spirit of Killing All Indians" in Pennsylvania, 1763-1764." Rhetoric \& Public Affairs 8, no. 3 (2005): 355-381.

Faull, Katherine M. "From Friedenshütten to Wyoming: Johannes Ettwein's Map of the Upper Susquehanna (1768) and an Account of His Journey." Journal of Moravian History 11 (2011): 82-96.

Fogleman, Aaron Spencer. Jesus Is Female: Moravians and the Challenge of Radical Religion in Early America. University of Pennsylvania Press, 2007.

Gollin, Gillian Lindt. "Family Surrogates in Colonial America: The Moravian Experiment." Journal of Marriage and Family 31, no. 4 (1969): 650-58. https://doi.org/10.2307/349305.

Gordon, Scott Paul. "The Paxton Boys and the Moravians: Terror and Faith in the Pennsylvania Backcountry." Journal of Moravian History 14, no. 2 (2014): 119-52.

Griffin, Patrick. American Leviathan: Empire, Nation, and Revolutionary Frontier. Macmillan, 2008.

Hamilton, Bishop J. Taylor. "The Contacts of the Moravian Church with the Iroquois League." Transactions of the Moravian Historical Society 11, no. 1 (January 1, 1931): 28-55.

Hark, Joseph Maximillian. Meniolagomeka: Annals of a Moravian Indian Village an Hundred and Thirty Years Ago. Clauder, 1880.

Hartzell, Lawrence W. Ohio Moravian Music. Moravian Music Foundation Press, 1988.

Hatley, Tom. The Dividing Paths: Cherokees and South Carolinians Through the Era of Revolution. Oxford University Press, 1993.

Hindle, B. The March of the Paxton Boys. The William and Mary Quarterly, 1946.

Hinke, William J, and Charles E Kemper. "Moravian Diaries of Travels through Virginia." The Virginia Magazine of History and Biography 11, no. 2 (1903): 113-131.

Huebner, Francis C. The Moravian Missions in Ohio. Washington, D.C., 1898.

Johnson, Frederick C. Count Zinzendorf and the Moravian and Indian Occupancy of the Wyoming Valley, (Pa.),1742-1763. Wilkes-Barre, Pa., 1904.

Jordan, John W. "Moravian Immigration to Pennsylvania, 1734-1767." Transactions of the Moravian Historical Society 5, no. 2 (1896): 51-90. 
Kenny, Kevin. Peaceable Kingdom Lost: The Paxton Boys and the Destruction of William Penn's Holy Experiment. Oxford University Press, 2009.

Lepore, Jill. "Historians Who Love Too Much: Reflections on Microhistory and Biography." The Journal of American History 88, no. 1 (June 2001): 129-144.

Levering, Joseph Mortimer. A History of Bethlehem, Pennsylvania, 1741-1892. Times publishing Company, 1903.

Little, Ann M. Abraham in Arms: War and Gender in Colonial New England. University of Pennsylvania Press, 2007.

Merrell, James H. Into the American Woods: Negotiators on the Pennsylvania Frontier. W. W. Norton \& Company, 2000.

Merritt, Jane T. At the Crossroads: Indians and Empires on a Mid-Atlantic Frontier, 1700-1763. The University of North Carolina Press, 2011.

. "Cultural Encounters along a Gender Frontier: Mahican, Delaware, and German Women in Eighteenth-Century Pennsylvania." Pennsylvania History 67, no. 4 (2000): 502-531.

Merritt, Jane T. "Dreaming of the Savior's Blood: Moravians and the Indian Great Awakening in Pennsylvania." The William and Mary Quarterly 54, no. 4 (1997): 723-746.

Mettele, Gisela. "Eine," Imagined Community", Jenseits Der Nation. Die Herrnhuter Brudergemeine Als Transnationale Gemeinschaft," 2006.

Nash, Gary B. "Poverty and Poor Relief in Pre-Revolutionary Philadelphia." The William and Mary Quarterly 33, no. 1 (1976): 3-30. https://doi.org/10.2307/1921691.

Otterness, Philip. Becoming German: The 1709 Palatine Migration to New York. Cornell University Press, 2013.

Parker, Arthur Caswell. Iroquois Uses of Maize and Other Food Plants. Albany, University of the state of New York, 1910. http://archive.org/details/iroquoisusesofma00parkrich.

Peucker, Paul. A Time of Sifting: Mystical Marriage and the Crisis of Moravian Piety in the Eighteenth Century. Penn State Press, 2015.

—. "Inspired by Flames of Love': Homosexuality, Mysticism, and Moravian Brothers around 1750." Journal of the History of Sexuality 15, no. 1 (January 2006): 30-64,165.

Pointer, Richard W. "An Almost Friend: Papunhank, Quakers, and the Search for Security amid Pennsylvania's Wars, 1754-65." The Pennsylvania Magazine of History and Biography 138, no. 3 (2014): 237-68.

Schutt, Amy C. "Tribal Identity in the Moravian Missions on the Susquehanna." Pennsylvania History: A Journal of Mid-Atlantic Studies 66, no. 3 (1999): 378-98.

—. "What Will Become of Our Young People?' Goals for Indian Children in Moravian Missions." History of Education Quarterly 38, no. 3 (October 1, 1998): 268-86.

Silver, Peter. Our Savage Neighbors: How Indian War Transformed Early America. W. W. Norton \& Company, 2009.

Sipe, Chester Hale. The Indian Wars of Pennsylvania: An Account of the Indian Events, in Pennsylvania, of the French and Indian War, Pontiac's War, Lord Dunmore's War, the Revolutionary War, and the Indian Uprising from 1789 to 1795 ; Tragedies of the Pennsylvania Frontier Based Primarily on the Penna. Archives and Colonial Records. Telegraph Press, 1929.

Stannard, David E. American Holocaust: The Conquest of the New World. Oxford University Press, 1993.

Stevens, Laura M. The Poor Indians: British Missionaries, Native Americans, and Colonial Sensibility. University of Pennsylvania Press, 2010. 
Thomas, Brian W. "Inclusion and Exclusion in the Moravian Settlement in North Carolina, 1770-1790." Historical Archaeology 28, no. 3 (January 1, 1994): 15-29.

Vickers, Daniel. A Companion to Colonial America. John Wiley \& Sons, 2008.

Vogt, Peter. "Everywhere at Home': The Eighteenth-Century Moravian Movement as a Transatlantic Religious Community." Journal of Moravian History, April 2013, 264.

Wallace, Anthony F C. King of the Delawares: Teedyuscung, 1700-1763. Syracuse University Press, 1949.

Wallace, Paul A. W. Indians in Pennsylvania. DIANE Publishing Inc., 2007.

—. "They Knew the Indian: The Men Who Wrote the Moravian Records." Proceedings of the American Philosophical Society 95, no. 3 (June 12, 1951): 290-95.

Walton, Joseph Solomon. Conrad Weiser and the Indian Policy of Colonial Pennsylvania. George W. Jacobs \& Co., 1900.

Weslager, C A. The Delaware Indians: A History. Rutgers University Press, 1989.

Wheeler, Rachel, and Thomas Hahn-Bruckart. "On an Eighteenth-Century Trail of Tears: The Travel Diary of Johann Jacob Schmick of the Moravian Indian Congregation's Journey to the Susquehanna, 1765." Journal of Moravian History 15, no. 1 (2015): 44-88.

White, Richard. The Middle Ground. Indians, Empires, and Republics in the Great Lakes Region, 1650-1815. Cambridge University Press, 2010. 